\author{
UNIVERSIDADE DE SÃO PAULO \\ MUSEU DE ARQUEOLOGIA E ETNOLOGIA \\ PROGRAMA DE PÓS-GRADUAÇÃO EM ARQUEOLOGIA
}

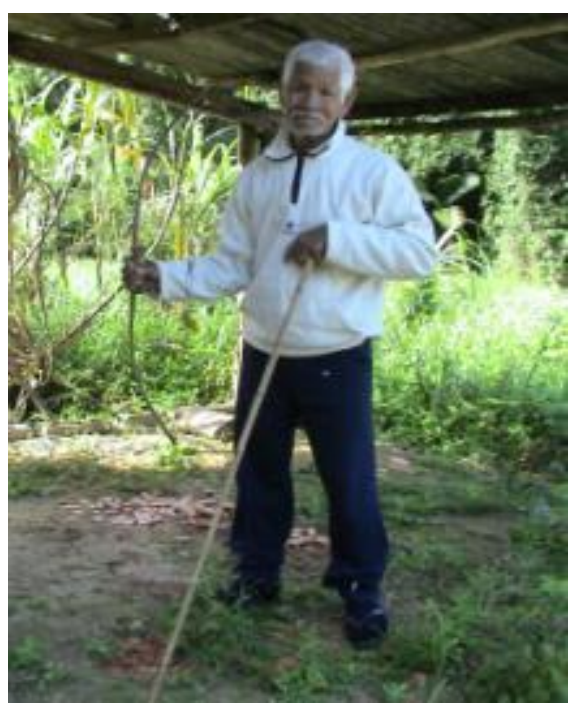

\title{
TERRA DE QUILOMBO:
}

\author{
ARQUEOLOGIA DA RESISTÊNCIA E \\ ETNOARQUEOLOGIA NO TERRITÓRIO MANDIRA. \\ MUNICÍPIO DE CANANÉIA/SP.
}

Fabio Guaraldo Almeida

São Paulo

2012 


\title{
TERRA DE QUILOMBO:
}

\author{
ARQUEOLOGIA DA RESISTÊNCIA E \\ ETNOARQUEOLOGIA NO TERRITÓRIO MANDIRA. \\ MUNICÍPIO DE CANANÉIA/SP.
}

\section{Fabio Guaraldo Almeida}

Bolsista FAPESP - processo 09/12355

\begin{abstract}
Dissertação de Mestrado apresentada ao Programa de Pós-graduação em Arqueologia do Museu de Arqueologia e Etnologia da Universidade de São Paulo.

Versão corrigida. A versão original encontra-se na biblioteca do MAE/USP.
\end{abstract}

Orientador: Prof ${ }^{a}$. Dr ${ }^{a}$. Fabiola Andréa Silva

Linha de Pesquisa: Espaço, sociedade e processo de formação do registro arqueológico.

São Paulo 


\section{Dedicatória:}

Ao meu filho Miguel, que com dois anos se senta na frente do computador e fala que está trabalhando. 
In memória

Ao Sr. Henrique Bernardo Couto Mandira. 


\title{
Dona Isabel \\ Mestre Toni Vargas
}

\author{
Iêêêêêê
}

Dona Isabel que historia é essa

Dona Isabel que história é essa, oh Iaiá

de ter feito a abolição

De ser princesa boazinha que libertou a escravidão

To cansado de conversa

to cansado de ilusão

Abolição se fez com sangue que inundava esse pais

Que o negro transformou em luta

cansado de ser infeliz

Abolição se fez bem antes e ainda há por se fazer agora

Com a verdade da favela

e não na mentira da escola

Dona Isabel chegou a hora

De se acabar com essa maldade

De ensinar aos nossos filhos

O quanto custa a liberdade

Viva Zumbi nosso rei negro, que fez-se herói lá em Palmares

Viva a cultura desse povo

A liberdade verdadeira

Que já subia nos quilombos

e já jogava capoeira

Iêêêêê viva Zumbi. 


\section{AGRADECIMENTOS}

É com muita satisfação que inicio esses agradecimentos. Após mais de três anos de pesquisa é chegado o momento de olhar para trás e relembrar com orgulho de todos que de alguma forma contribuíram com o resultado desse trabalho. Realmente foram tantas as pessoas, que desde já me desculpo por não conseguir citar todos, mas tenho certeza que de alguma forma todos serão lembrados.

Começo agradecendo minha família, pois nesses últimos anos apreendi a responsabilidade de constituir uma família. Obrigado Fabi por estar comigo nessa jornada. Ser pai ao seu lado é a coisa mais bonita que aconteceu na minha vida. Sua presença me conforta. Te agradeço com amor e alegria.

Agradeço ao meu avô Paulo e à minha avó Rita pelo exemplo de vida e todo o aconchego durante os fins-de-semana em Cotia, sempre com festa, alegria e a presença dos familiares/amigos. Agradeço muito pela família de que faço parte com meus tios e tias, meus primos e primas, os primos/sobrinhos Matteo, Liam e o próximo com meses de gestação, o amigo Carlinhos, minhas irmãs Camila, Tatiane, os cunhados Rodrigo, Wellington e a pequena Bianca. Minha cunhada e comadre mariana Leite. Meu pai Delfim, a querida Solange e minha irmã Beatrice, que apesar da distância física os pensamentos estão sempre juntos. Agradeço à minha sogra Ivone por ter ficado as tardes com meu filho para que eu pudesse trabalhar na dissertação. Mas não posso deixar de agradecer principalmente ao meu irmão Danilo, quem alem de ser um grande amigo e companheiro, trabalhou junto comigo na elaboração dos mapas, e à minha mãe querida, Marilena, que sempre me apoiou e acreditou nas minhas escolhas.

O trabalho com os Mandira me proporcionou conhecer uma das cidades mais bonita e interessante que já havia visitado. Cananéia é um lugar cheio de histórias e mistérios, onde em cada esquina existe alguém pronto pra revelar mais uma oratória intrigante. Durante o tempo de pesquisa fui muito bem acolhido pelas pessoas da cidade e alguns se tornaram verdadeiros amigos. Por isso agradeço imensamente à todo o pessoal do "Ponto de Cultura Caiçara", na figura do Fernando Oliveira, com quem primeiro fiz contato e sempre tive como referência pelo trabalho competente e empolgante que realiza. O Cleber Rocha Chiquinho, quem primeiro me hospedou, ainda na fase de elaboração do projeto, sua intimidade com a cultura local e alegria são contagiantes. Ao casal Codorna (também conhecido como Juliano) e Bianca, com seu 
filho Rudá, com quem compartilhamos bons momentos de conversas e experiências sobre parto humanizado, conhecimentos tradicionais dos caiçaras e as alegrias e rotinas da vida em família. Aos amigos e colegas Adriano Bananinha, Luis carioca, Mayra, Marina, Rafa, Rodolfo, Fernanda, Erick, Gisele, Natália, André, Nat, Silmara, Ivan, Fabio e Ju, ao Fabinho do Hotel Coqueiros, ao Agrício do Toyo Joyo, ao Paulo do EAACONE e todos os demais que trabalham para a educação, como professores, e para a cultura e pesquisa local pela Rede Cananéia, pelo IpeC e outras instituições. Agradeço muito a vocês pelas conversas, debates, festas, eventos, viagens, noites de fandango com cataia e muita alegria.

Faço questão de agradecer à Ester Palhares, que conheci a primeira vez quando ela cantava sua música sobre o Mandira e hoje é uma grande amiga, conselheira e médica espiritual. Guerrera, estamos juntos na guerra da paz! Aos artistas Tuneu e Guilherme, pessoas admiráveis com quem pretendo realizar muitos trabalhos. Ao casal André e Pati Mattana e seus filhos Lucas e Enzo, que acompanharam a pesquisa desde o início, inclusive ajudando com a revisam de alguns capítulos. Obrigado pelo apoio, companheirismo, amizade e momentos de conversas, desabafos e boas descontrações.

Aos amigos e colegas da arqueologia, que nesses últimos anos tem sido minha maior convivência nos longos trabalhos de campo, na rotina do museu, nos congressos e conferências. Agradeço aos companheiros Chico Pipoca e suas peripécias, Eduardo Chumbinho e suas escavações muito malucas, Dani Amaral, Ângelo Corrêa, Meliam Garcia, Alexandre Robazzini, Frederic Pouget, Patrícia Ficher, Thiago Atorre, Patrícia Marinho, Danilo Assunção, Alexandre Hering, Rafael Milheira, Aluísio Alves, Rafael Brandi, Márcia Arcuri, Lucia Juliane, Rucirene Miguel e tantos outros.

À todo o pessoal dos sítios escolas do Projeto Amazônia Central, coordenado pelo Dr. Prof. Eduardo Goes Neves, na figura do próprio Professor Eduardo e dos companheiros Eduardo Kazu, Bernardo, Felippo, Marjorie, Rodrigo, Jaques, Pitoco, Guilherme, Helena, Raoni, Silvinha, Anne, Claide, Marcinho, Lei, Merrinha, Gabiru, Pupa, Seu Nego, Seu Bené e todos os outros com quem aprendi o que é um campo arqueológico de alta qualidade. Agradeço principalmente também a equipe de Educação Patrimonial do PAC, coordenada pela Dra. Carla Gibertoni e composto pelos amigos Maria Tereza e Maurício Sílva. Tenho certeza que nossa experiência na Amazônia trabalhando principalmente com a população de Iranduba, foi o ponta pé inicial de nossa formação enquanto arqueólogos, demonstrando que existem caminhos para a descolonização da prática arqueológica. 
À todos os docentes e funcionários do MAE, em especial ao pessoal da biblioteca: Helio, Alberto, Gilberto e Eleuza, que sem dúvida nenhuma foram fundamentais pra esse trabalho, as meninas do Xerox: Sandra e Taia, a Dona Nice, que é a pessoa mais procurada no museu e principalmente agradeço ao pessoal do Educativo: Judith Elazari, o professor Camilo Vasconcellos e a Carla Gibertoni, com quem trabalhei como estagiário por mais de dois anos durante minha graduação.

À Maria Inez, funcionária do ITESP, por sua solicitude ao facilitar a pesquisa no Relatório Técnico-científico realizado no Mandira, com mapas e documentos oficiais. Aos funcionários do Arquivo Público que ajudaram o acesso aos documentos históricos fundamentais para esse trabalho. À Eloisa do Instituto Oceanográfico da USP, por ajudar na pesquisa do acervo histórico fotográfico de Cananéia, e no fornecimento das fotos escolhidas.

Agradeço ao CNPq pelo fornecimento de bolsa nos primeiros seis meses do mestrado. E à Fundação de Apoio a Pesquisa do Estado de São Paulo (FAPESP) pelo suporte financeiro via bolsa de mestrado nos período seguinte e pelos pareceres científicos que avaliaram cada etapa da pesquisa (PROCESSO 2009/12355-2).

Agradeço também aos Professores Doutores Paulo DeBlasis, Francisco Noeli, Paulo Zanettini, Pedro Paulo Funari, Flávio Calippo, Paulo Bava, com quem tive conversas informais ao longo da pesquisa e transmitiram apoio e incentivo, inclusive indicando bibliografias, para eu trabalhar com o tema na região.

Mas sem dúvida a pessoa que mais agradeço pelo incentivo, paciência, confiança e orientação é a Professora Doutora Fabíola Andréa Sílva. Agradeço muito por confiar e acreditar em um aluno que propôs trabalhar com comunidade quilombola. $\mathrm{O}$ comprometimento social e político que exerce enquanto cientista e professora é um dos maiores exemplos que um aluno pode ter. Mais que uma pesquisadora surpreendente é uma pedagoga exemplar. Agradeço por ter se tornado a principal pessoa em minha formação acadêmica.

Por fim, meus eternos agradecimentos à todos da comunidade quilombola dos Mandira. Esses mais de três anos que temos de convívio ampliou minha visão de pessoa e de mundo. Na pessoa de Seu Chico e Dona Irene agradeço pela hospitalidade, com comida, teto e cama vocês foram verdadeiros pais nos dias frios de inverso ou no sol quente do verão que passei entre os Mandira. Na pessoa do Luis e do Nei agradeço a todos por terem aceitado minha proposta de pesquisa, participado ativamente do levantamento dos dados e compartilhado das leituras e interpretações descritas nessa 
dissertação. Espero que esse trabalho não fique apenas nas prateleiras das bibliotecas, mas possa contribuir de alguma forma ao que ela se propõe: ser um instrumento na luta das comunidades quilombolas pelo reconhecimento social e político na titulação de suas terras.

Contudo, me responsabilizo inteiramente por tudo que está exposto nas páginas seguintes. 


\section{RESUMO}

Tendo em vista as discussões sobre a realidade das comunidades quilombolas e a forma como a arqueologia é acionada e se posiciona nos debates sobre o tema, o presente trabalho discute sobre a prática arqueológica em comunidade quilombola, contribuindo com os debates da Arqueologia Pública e Comunitária. Para tal, apresentamos o estudo etnoarqueológico no território quilombola dos Mandira, situado no município de Cananéia, no Baixo Vale do Ribeira.

Para pesquisas arqueológica em comunidade quilombola é crucial o entendimento da trajetória histórica de formação dos territórios, pois este conhecimento, muitas vezes é utilizado como ferramenta dos direitos territoriais desses povos. Através do estudo fenomenológico da territorialidade do Mandira objetivamos entender o modo de apropriação dos elementos e marcos da paisagem, incluindo os vestígios arqueológicos, que constituem o conjunto de lugares de resistência formador desta paisagem. Sendo assim, a partir de uma proposta de pesquisa multivocal e interdisciplinar entre arqueologia, antropologia, história e geografia procuramos explorar o modo como os Mandira interpretam a diversidade de vestígios arqueológicos presentes em seu território, para demonstrar como isso implica no seu processo de ocupação e formação.

Palavras Chave: Territorio; Quilombola; Mandira; Etnoarqueologia; Patrimônio cultural. 


\section{ABSTRACT}

In view of the maroons studies and how archaeology is thrown to position themselves in these discussions, the present work discusses about the archaeological practices in maroons communities, contributing to the debates of the Community and Public Archaeology. For that, we presented the study etnoarchaeological within maroons of Mandira, located in the municipality of Cananéia, in the Ribeira Valley low.

For archaeological research in maroon is crucial to understand the historical background of the formation of territories because, this knowledge is often used as a tool of territorial rights of these people. Through the phenomenological study of territoriality of Mandira aim to understand the mode of appropriation of landmark and elements of the landscape including archaeological remains, which are the set of places of resistance forming this landscape. Thus, from a multivocal and interdisciplinary research between archaeology, anthropology, history and geography seek to explore how the diversity of Mandira interpret archaeological remains in their territory, to demonstrate how this implies the process of occupation and formation.

Key-words: Territory; Maroon; Mandira; Etnoarchaeology; Cultural heritage. 


\section{Sumário}

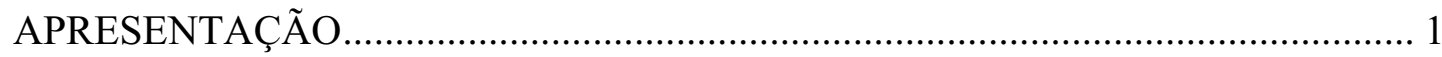

1. ARCABOUÇO TEÓRICO E METODOLÓGICO .............................................. 6

1.1 Introdução: As perspectivas antropológica e histórica sobre a atual noção de quilombo.

1.2 Arqueologia da resistência escrava: uma abordagem da arqueologia da escravidão.

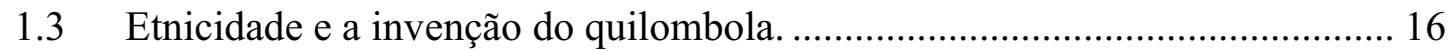

1.4 Diferentes abordagens arqueológicas sobre comunidades quilombolas.......... 18

1.5 Etnoarqueologia e Arqueologia do Presente................................................... 24

1.6 Narrativas e história oral como fontes da memória. ...................................... 29

1.7 Comunidade, negociação e aplicação metodológica. ..................................... 35

2. A HISTÓRIA QUILOMBOLA MANDIRA..................................................... 41

2.1 Posição geográfica e características ambientais da Comunidade. ................... 41

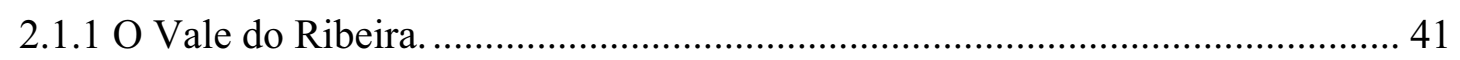

2.1.2 Aspectos físicos do município de Cananéia. ................................................... 43

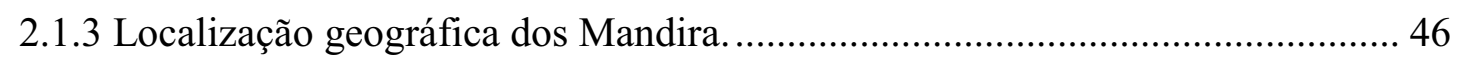

2.2 Histórico de formação da comunidade quilombola Mandira........................... 47

2.2.1 A família Andrade em Cananéia. ..................................................................... 48

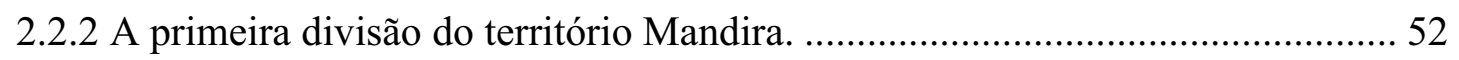

2.2.3 Atividades econômicas: a caça e a roça............................................................... 54

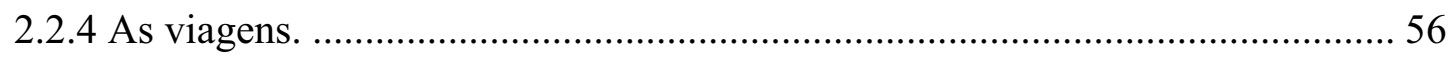

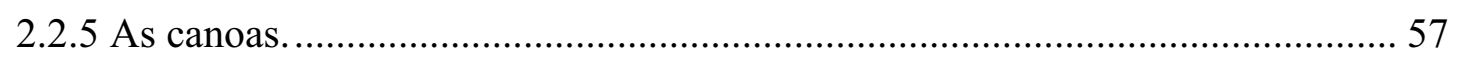

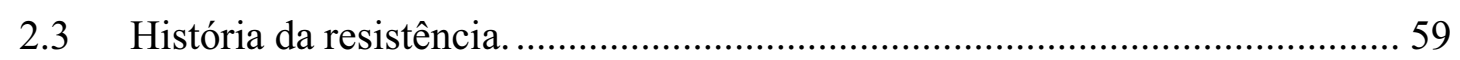

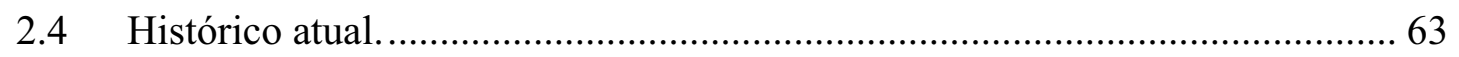

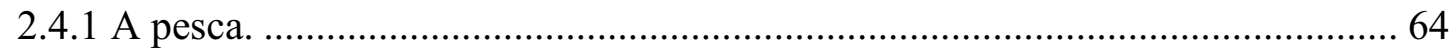

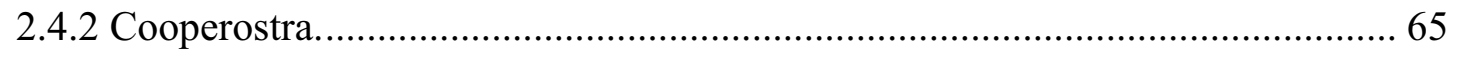

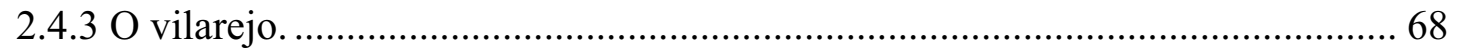

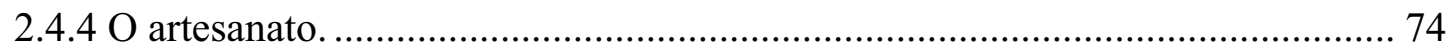

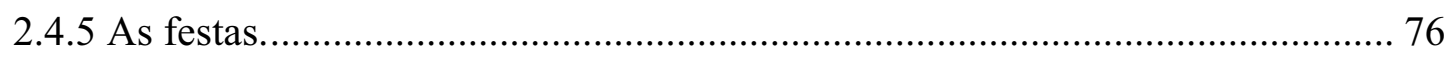

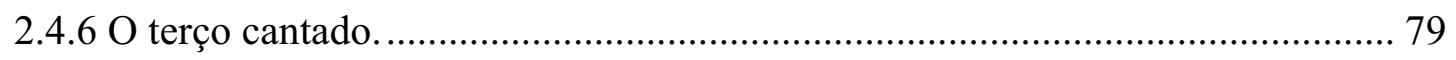


3. O TERRITÓRIO QUILOMBOLA MANDIRA............................................... 82

3.1 FENOMENOLOGIA DA PAISAGEM: espaço, paisagem e lugares ............. 82

3.2 TERRITÓRIO ENQUANTO OBJETO AGREGADO: Terra, território,

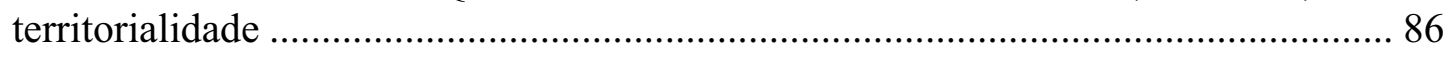

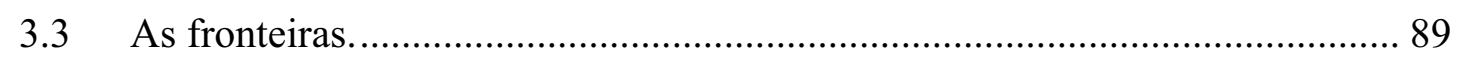

3.4 Portos, mangues e canais como lugares culturais......................................... 92

3.5 Os antigos carreadores e os caminhos contínuos.......................................... 100

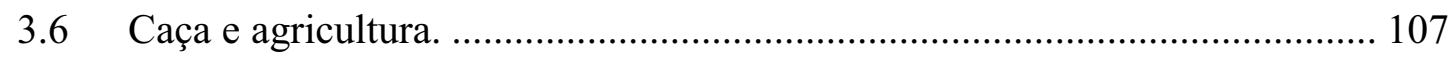

4. AS DIVERSAS OCUPAÇÕES NO TERRITÓRIO MANDIRA ..................... 113

4.1 Lugares de histórias e histórias dos lugares: os sítios arqueológicos. ............ 113

4.1.1 A Casa-de-pedra/ O engenho de arroz. ..................................................... 114

4.1.2 A Casa-de-pedra/ A Revolução de 1932 ..................................................... 116

4.1.3 O Abacateiro/ O Sambaqui/ O dilúvio...................................................... 118

4.1.4 A Camboa/ O Caratuba/ Os Sambaquis. ..................................................... 120

4.1.5 O Palimpsesto na paisagem do Território. ................................................ 123

4.1.6 A Barra do rio/ Os estaleiros/ O dilúvio................................................... 125

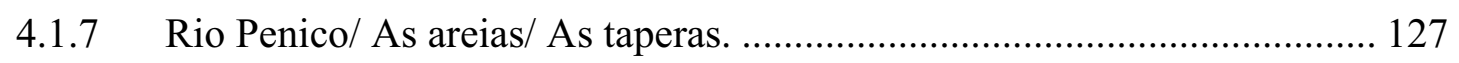

4.2 A reformulação da paisagem. .................................................................. 132

5. ARQUEOLOGIA E PATRIMÔNIO QUILOMBOLA....................................... 135

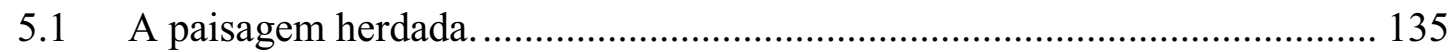

5.2 Contradição: A titulação como Área de Proteção Ambiental (APA). ............ 136

5.3 A institucionalização da "Gestão do Patrimônio Arqueológico". ................. 138

5.4 O patrimônio quilombola no contexto brasileiro.......................................... 141

5.5 O conflito intrínseco ao patrimônio cultural.................................................. 147

5.6 Conclusão: Território Quilombola como Patrimônio..................................... 152

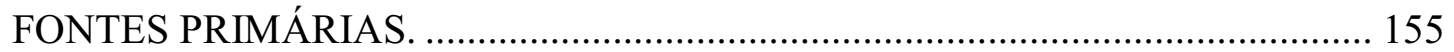

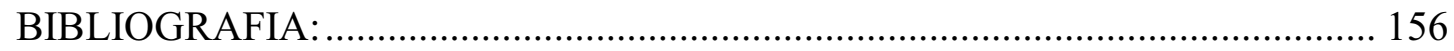

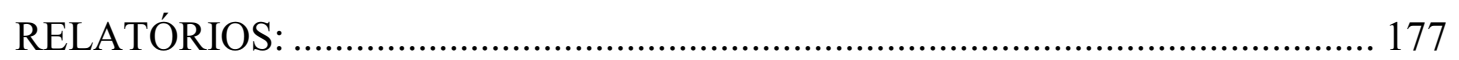

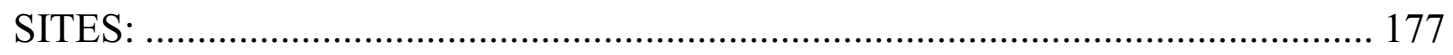

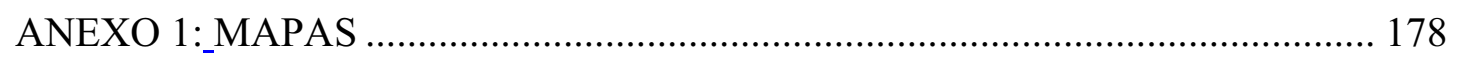

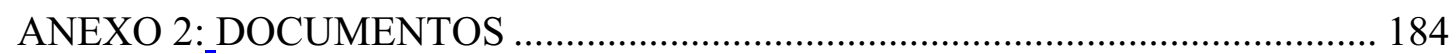

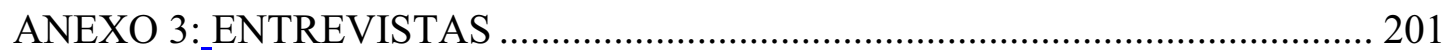




\section{Tabela.}

Tabela 1: Divisão geomorfológica do Baixo Vale... 44 


\section{Lista de figuras.}

Figura 1: Reunião da RESEX Mandira, quando foi apresentado o Kit de Educação

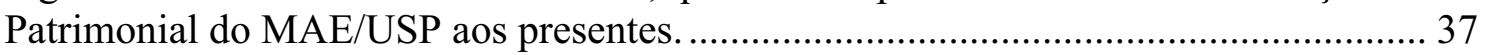

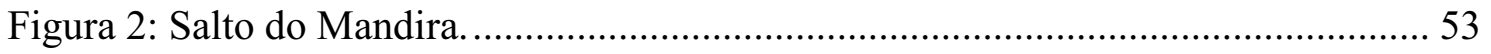

Figura 3: Estrutura do antigo porto na ilha de Cananéia, ao lado da atual balsa............ 56

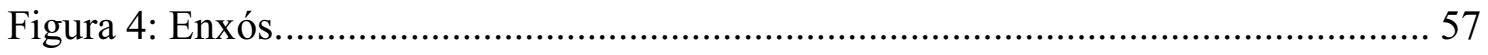

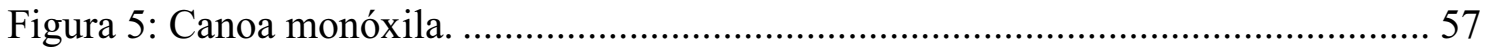

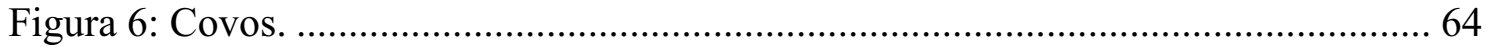

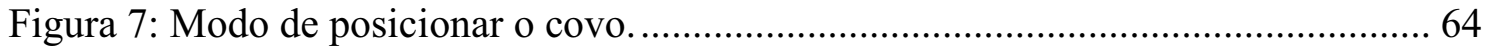

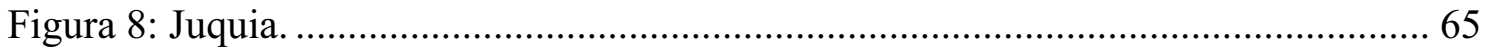

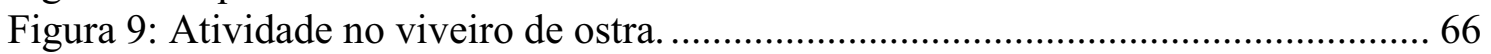

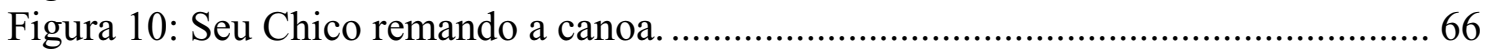

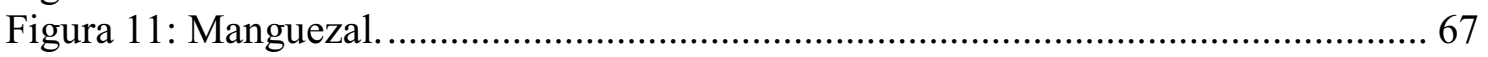

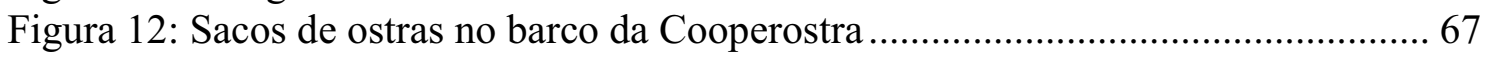

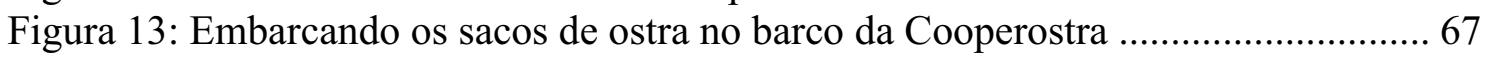

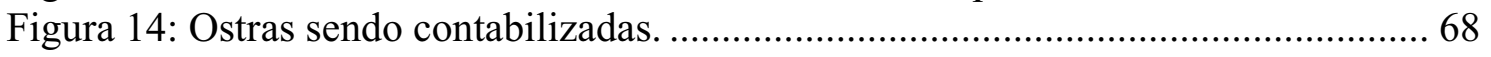

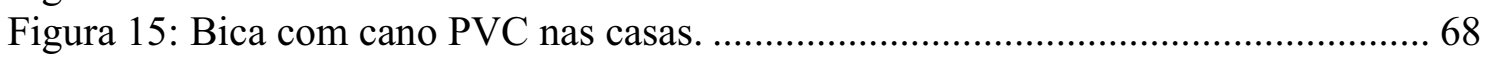

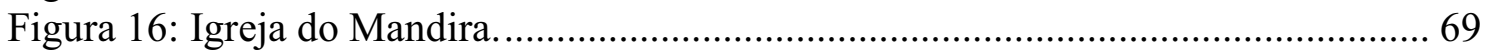

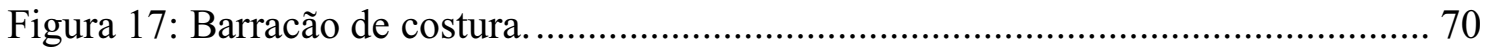

Figura 18: Cozinha comunitária. ........................................................................ 70

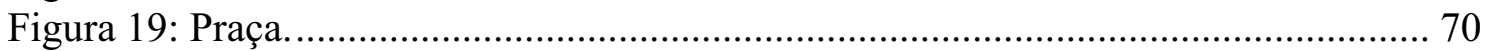

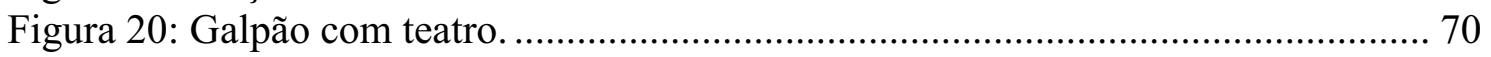

Figura 21: Ruas pavimentada com casca de ostra................................................... 71

Figura 22: Casqueiro sendo medido com ajuda da pequena Gabriela.......................... 71

Figura 23: Casa de Seu Jango e Dona Creusa. .............................................................. 71

Figura 24: Casa de alvenaria com corte do terreno. ................................................. 72

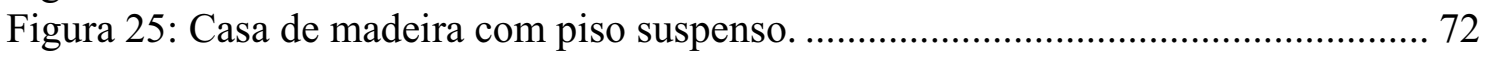

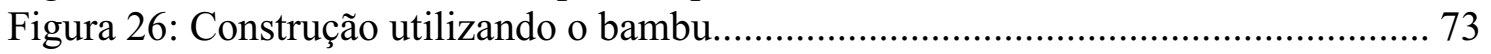

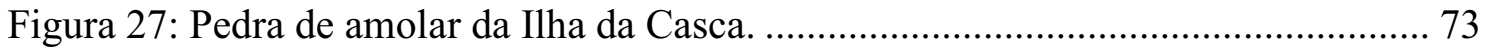

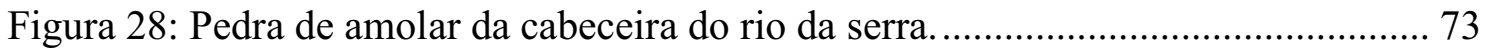

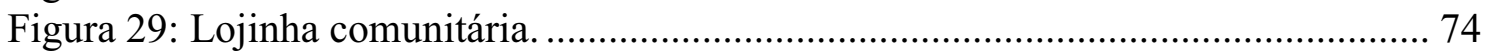

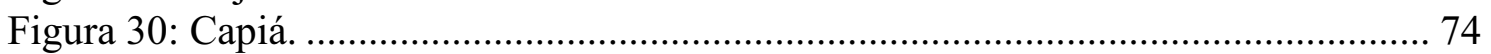

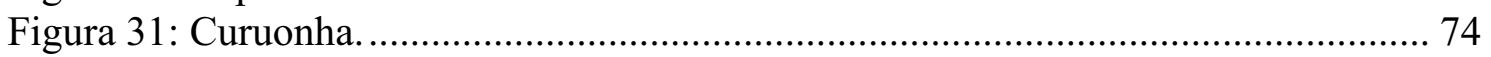

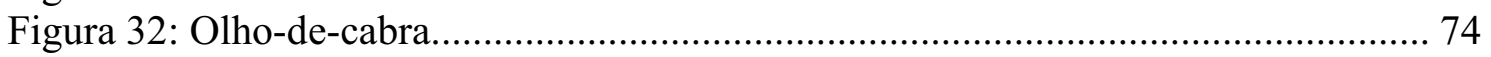

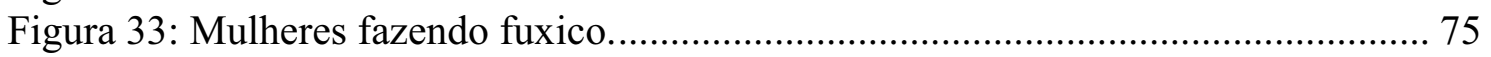

Figura 34: Dona Creusa confeccionando cesto com Imbé. ....................................... 75

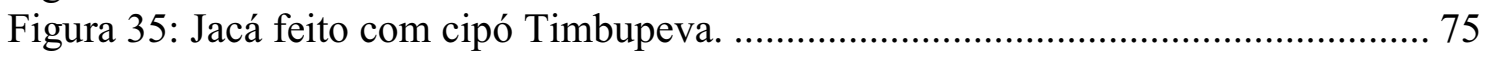

Figura 36: Dona Creusa com as esteiras de Peri. ......................................................... 76

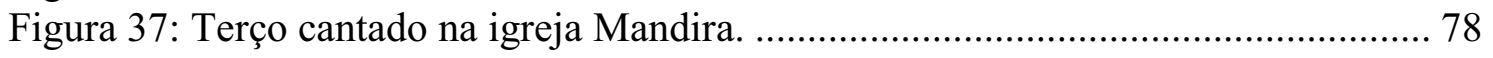

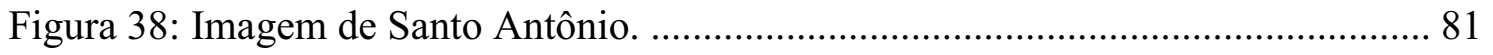

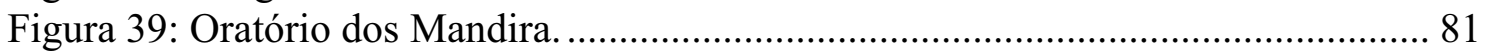

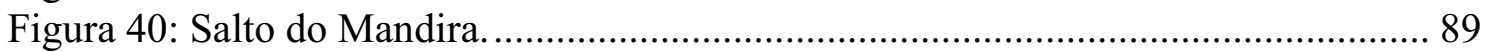


Figura 41: Vista do território Mandira pela Barra do rio. ............................................ 92

Figura 42: Detalhe dos materiais de confecção dos viveiros....................................... 93

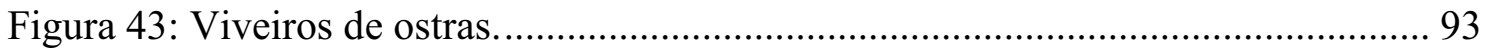

Figura 44: Detalhe da aglomeração dos esteios dos antigos viveiros abandonados no

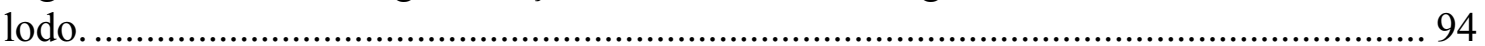

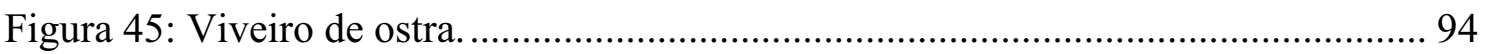

Figura 46: Viveiro e esteios dos antigos viveiros abandonados no lodo........................... 94

Figura 47: Aspecto do Rio das Minas em 1956 (Acervo IO/USP). .............................. 95

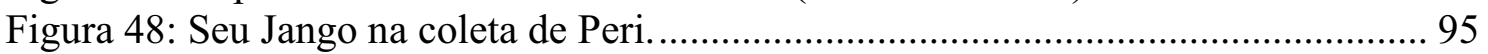

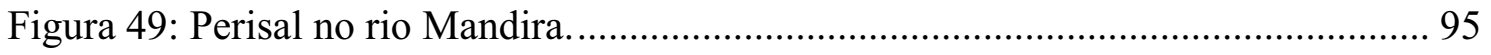

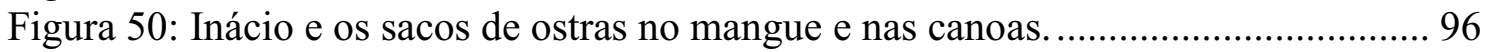

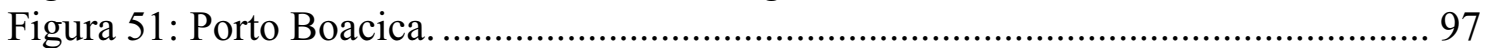

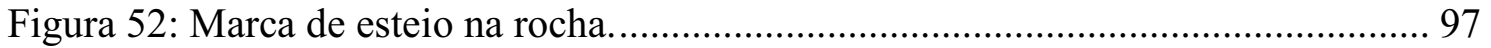

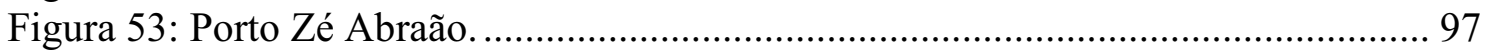

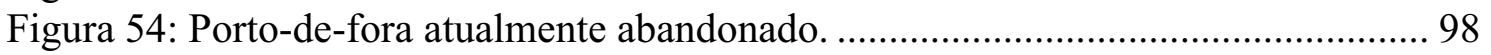

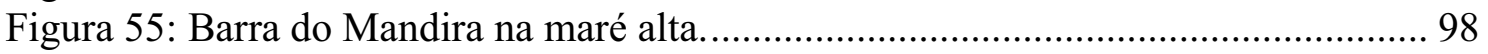

Figura 56: Caminho dos antigos. Trilha do Pindauva. ............................................... 100

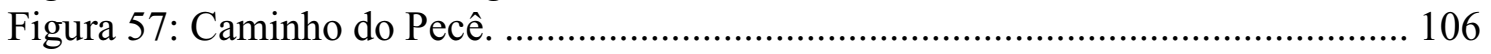

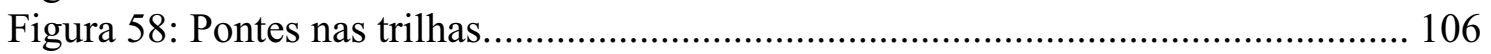

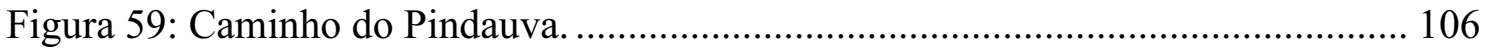

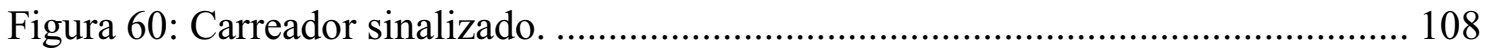

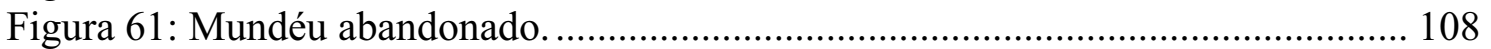

Figura 62: Laço pra caçar gambá e paca. (Fonte:

http://triboescoteira.blogspot.com.br/2008/02/armadilha-ii-armadilha-de-lao-i-1-

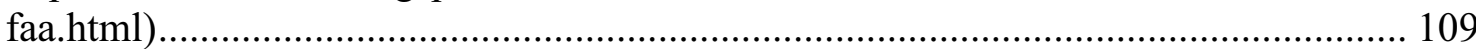

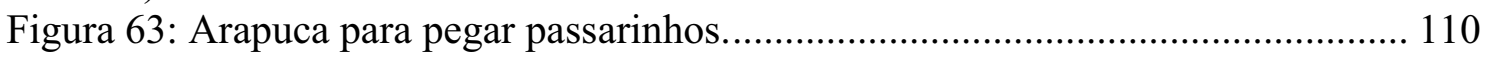

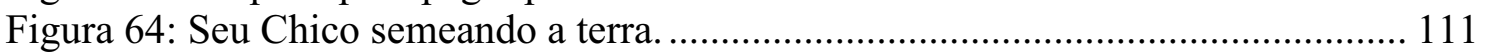

Figura 65: Detalhe do tamanho das pedras, da fresta e da argamassa.......................... 114

Figura 66: Fachada frontal da Casa-de-pedra do Mandira. ........................................... 114

Figura 67: Lateral de paredes altas com três janelas e uma porta. ................................ 114

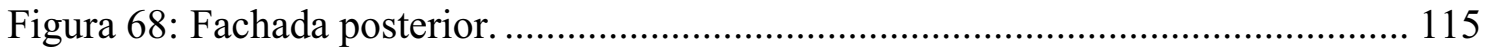

Figura 69: Luis na vala de condução hidráulica na vertente do morro......................... 115

Figura 70: Vestígio da parede divisória interna. Detalhe para o vão na lateral esquerda

da parede, por onde entrava a água para mover o moinho. ...................................... 115

Figura 71: Lâmina de faca, com cabo estilizado, encontrado na região....................... 117

Figura 72: Tigela de metal encontrada por Seu Leonardo. ......................................... 117

Figura 73: Seu Leonardo. Com uma espingarda encontrada na região........................ 117

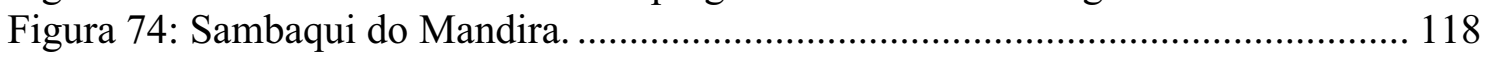

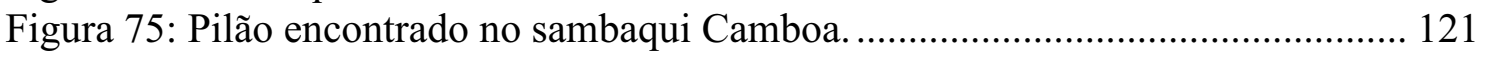

Figura 76: Sambaqui da Camboa em destaque na paisagem..................................... 121

Figura 77: Objeto lítico encontrado, provável quebra-coquinho............................... 121

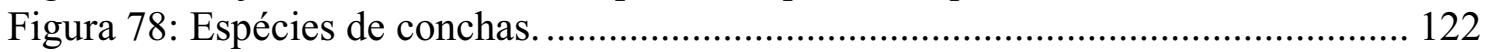

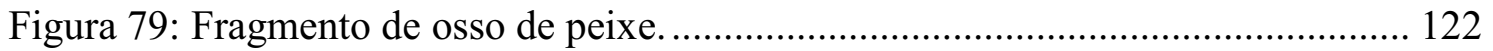

Figura 80: Nei Mandira na base exposta do sambaqui................................................ 122

Figura 81: Vestígio de construção de pedra em cima do sambaqui. ............................. 124

Figura 82: Palimpsesto evidenciado na paisagem: estrutura de ocupação histórica sobre

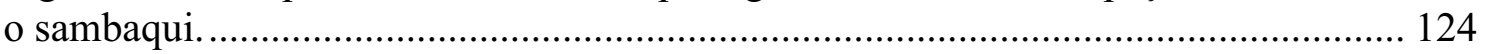

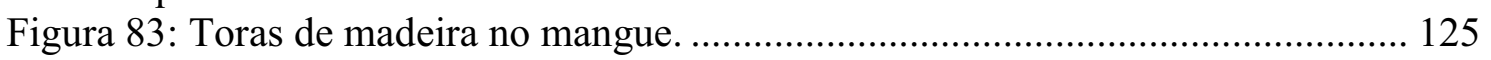

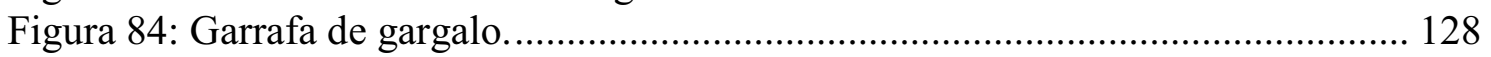

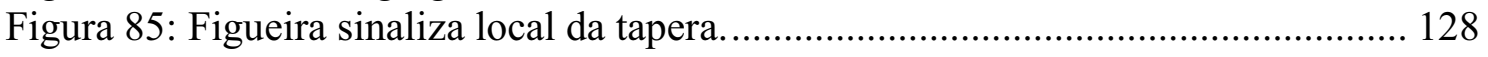




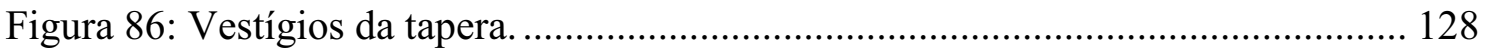

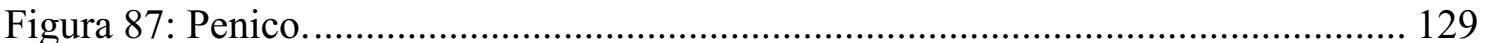

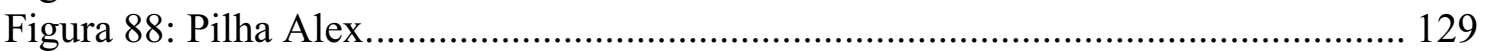

Figura 89: Fossa na tapera da Dona Zumira.............................................................. 130

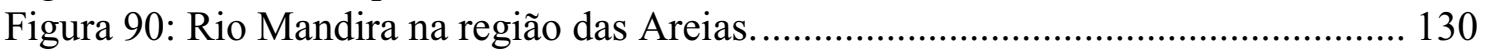

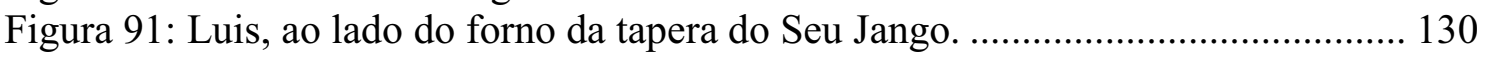

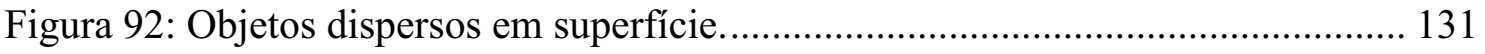

Figura 93: Pedra de quartzo com evidência de resina com conchas trituradas. ............ 131 


\section{APRESENTAÇÃO}

Ainda são incipientes as pesquisas etnoarqueológicas em comunidades autodefinidas e reconhecidas como remanescentes quilombolas no Brasil. Segundo o historiador Adelmir Fiabani, entre os estudos realizados sobre remanescentes de quilombo predominam os trabalhos antropológicos: "Acontece que para o reconhecimento de uma comunidade como remanescente de quilombo há a necessidade de um laudo antropológico. Muitas das obras citadas são laudos das referidas comunidades" (FIABANI, 2005:8). Tais laudos, que têm como finalidade proporcionar a titulação das terras em benefício das comunidades reconhecidas, adotam como estratégia o levantamento das origens históricas, os processos de transformações e configurações sociais sobre os quais as comunidades estão organizadas e as condições de vida que caracterizam o espaço territorial destas comunidades.

A Arqueologia, por sua vez, é a ciência humana especializada em evidenciar, registrar e analisar os vestígios materiais em espaços determinados, com o intuito de examinar como se procedeu a ocupação humana ao longo do tempo nestes lugares. Os arqueólogos investigam as sequências de eventos do passado através do estudo em espaços determinados. Ou seja, para entender o passado o arqueólogo busca entender os lugares (BINFORD, 1983).

Sendo assim, questionamos o fato de os laudos de reconhecimento territoriais para titulação de terras e pesquisas antropológicas com os grupos considerados "remanescentes de quilombos" terem fraco diálogo com a arqueologia.

Em 1998 ocorreu a Primeira Reunião Internacional de Teoria Arqueológica na América do Sul, realizada durante a XXI Reunião da Associação Brasileira de Antropólogos em Vitória. Incentivados pelos dez anos da promulgação da Constituição 
Brasileira - que determinou pelo artigo 68 do Ato das Disposições Constitucionais Transitórias (ADCT), que fossem conferidos direitos territoriais aos remanescentes de quilombos que estejam ocupando suas terras, sendo-lhes garantida a titulação definitiva pelo Estado - vários trabalhos antropológicos sobre comunidades quilombolas foram apresentados, bem como algumas pesquisas arqueológicas sobre o tema. Deste modo, apesar das escavações arqueológicas em quilombo acontecerem desde o fim da década de 1970, foi a partir desse encontro entre arqueólogos e antropólogos que um profícuo debate sobre pesquisa arqueológica em território quilombola se iniciou no Brasil de forma significativa (FUNARI, 1998). Entretanto, passados mais de dez anos, poucos avanços tivemos em um terreno que ainda há muito para ser explorado.

No intuito de colaborar com esse debate, o presente trabalho traz uma pesquisa etnoarqueológica na comunidade quilombola Mandira, situada no município de Cananéia, no Baixo Vale do Ribeira, considerando os elementos sociais e históricos e demonstrando as profícuas contribuições que a arqueologia oferece aos estudos sobre identidade, território e patrimônio cultural.

Este trabalho se apresenta em cinco capítulos, com subdivisões em cada um deles. O critério de divisão dos capítulos levou em conta a apresentação dos caminhos teóricos utilizados na abordagem dos diferentes assuntos relacionados com o tema. Assim, o primeiro capítulo apresenta o arcabouço teórico-metodológico no qual a dissertação se baseia para desenvolver uma prática arqueológica em comunidade quilombola. Discorremos, em um primeiro momento, sobre os debates e estudos históricos e antropológicos para situar o leitor no tema. Em seguida, pelo viés da Arqueologia Histórica é exposto o caminho pelo qual a Arqueologia da Resistência Escrava se constituiu enquanto parte da Arqueologia da Escravidão. 
A pesquisa etnoarqueológica no quilombo Mandira se desenvolve a partir da perspectiva da Arqueologia do Presente. Mesmo a Arqueologia do Presente definida por Gonzalez-Ruibal (2008) como algo distinto das pesquisas etnoarqueológicas comumente trabalhadas, nossa abordagem etnoarqueológica buscou princípios teóricos da Arqueologia do Presente para, entre outras coisas, estabelecer uma postura ética e política à medida que promovemos uma relação simétrica no trabalho com os Mandira.

Nosso trabalho também se desenvolve dentro de alguns parâmetros teóricometodológicos do que se define como Arqueologia Pública ou Comunitária. Buscamos construir uma proposta de trabalho que antes de tudo fosse de interesse da comunidade, no intuito de que pesquisador e comunidade sejam co-participantes nas etapas de construção do conhecimento arqueológico.

Procuramos explorar as diferentes vozes sobre o passado a partir das interpretações dos elementos presentes na paisagem cultural do território quilombola. Para isso, utilizamos das narrativas e histórias orais na pesquisa etnoarqueológica como fontes de análises e instrumentos de interpretação sobre o processo de formação do território Mandira.

Com isso, nos capítulos seguintes, expomos com detalhes os resultados do trabalho de campo etnoarqueológico. No segundo capítulo, descrevemos a localização dos Mandira e a história de formação dessa comunidade quilombola. Pela perspectiva da etnoarqueologia destacamos alguns aspectos da cultura material dos Mandira que envolvem essas narrativas históricas. Entre estas narrativas se sobressaem os relatos de resistência através dos quais o grupo se constitui hoje enquanto comunidade quilombola.

No terceiro capítulo, exploramos a territorialidade dos Mandira na formação de seu território. No intuito de revelar a relação espaço-tempo e homem-natureza que 
envolve esse processo, utilizamos a abordagem fenomenológica da Arqueologia da Paisagem discutida no início do referido capítulo. Através da vivência e histórias compartilhadas, buscamos entender o conjunto de lugares significativos formador da paisagem de resistência que caracteriza o território quilombola.

Aprofundando o estudo da territorialidade e da formação da paisagem cultural no território Mandira, o quarto capítulo apresenta a interpretação que os próprios quilombolas fazem dos vestígios arqueológicos em seu território. $\mathrm{Na}$ primeira parte, o capítulo explora o modo como os Mandira reagem à diversidade de vestígios arqueológicos presentes em suas terras e demonstra como isso implica diretamente no processo de formação destas.

Na segunda parte do capítulo, tendo compilado as narrativas e histórias orais associadas aos vestígios da história de ocupação e a formação da paisagem cultural, podem ser vislumbrados os processos de continuidade, mudanças e rupturas na trajetória dessa população durante a ocupação e formação desse território quilombola.

Desse modo, um trabalho que visa a demonstrar as diferentes vozes interpretativas sobre o passado e os significados dos registros arqueológicos não pode privar-se de discutir o conceito de patrimônio. Para tanto, realizamos uma abordagem teórica própria para tratar o patrimônio cultural e arqueológico em território quilombola no último capítulo.

A fim de produzir um fechamento mais completo e condizente com a proposta da dissertação, discorremos sobre as dicotomias envolvendo o tema patrimônio, a institucionalização da arqueologia na gestão do patrimônio cultural no mundo, a legislação em torno do patrimônio quilombola no Brasil, para finalmente pensar no território enquanto patrimônio quilombola. 
Entender a trajetória histórica de formação dos territórios torna-se crucial em contextos de pesquisa arqueológica em quilombo, pois este conhecimento muitas vezes é utilizado como ferramenta fundamental dos direitos territoriais desses povos e, particularmente, de garantia de suas terras. Em todo o mundo os arqueólogos vêm sendo chamados a se posicionarem frente às questões relativas à definição de posse e delimitação dos territórios de populações tradicionais e preservação do patrimônio arqueológico encontrado naqueles. Por outro lado, o próprio conhecimento produzido por algumas correntes teóricas da Arqueologia vem sendo questionado dentro da academia pelas interpretações de outras áreas científicas e por segmentos sociais relacionados à causa negra (p. ex. ALMEIDA, 1998; FUNARI, 2001).

Torna-se cada vez mais necessário alcançar um entendimento mais profundo e diversificado a respeito dessas populações que fizeram parte do nosso processo histórico de ocupação territorial e, por isso, hoje ocupam parte do território nacional, embora constantemente têm visto suas terras ameaçadas por uma herança histórica de preconceito.

Sendo assim, esta dissertação pretende refletir sobre a prática arqueológica em território quilombola e, nesse sentido, o diálogo entre Arqueologia, Antropologia, História e Geografia é imprescindível. 


\section{ARCABOUÇO TEÓRICO E METODOLÓGICO}

\subsection{Introdução: As perspectivas antropológica e histórica sobre a atual noção de quilombo.}

O termo quilombo deriva da palavra bantu kilombo. Essa palavra foi pronunciada no Brasil pelos povos africanos de lunda, ovimbundu, mbundu, kongo, imbangala e outros trazidos como escravos, cujo território se divide hoje entre as regiões de Angola e Zaire. Apesar de kilombo ser uma palavra da língua umbundu, seu significado remete a uma milícia iniciática de jovens da região mbundu adotada pelos invasores Java (ou imbangala). Esta milícia era formada por homens guerreiros de várias etnias, desenraizados de suas comunidades e introduzidos na milícia através de rituais de iniciação para servirem ao comando da grande líder, a Rainha Ginga. Com forte atuação na África subsaariana no século XVII, a milícia da Rainha Ginga ficou conhecida por suas histórias de lutas e conquistas e temida por sua força e ousadia. Combatiam não só os colonizadores, mas também outras etnias africanas, conforme seus interesses e acordos (MUNANGA, 1995) ${ }^{1}$.

Apesar da Rainha Ginga nunca ter vindo para o continente americano, sua fama e exemplo de luta atravessou o Atlântico. Revoltas e atos de resistência ao regime escravocrata se deram em todo o Novo Mundo. As formas como essas resistências se constituíram e o modo como foram denominadas são próprias do contexto social e histórico ao qual estavam sujeitas. No Brasil, o termo quilombo é encontrado pela primeira vez em documentos do século XVIII. Antes disso, os lugares onde se concentravam os negros insubmissos ao cativeiro eram genericamente denominados pelos portugueses de mocambos, termo oriundo de mukambu, voz africana do quimbundo, significando literalmente "telhado de palha" (FREITAS, 1977). A partir do começo do século XVIII, a palavra kilombo foi adaptada ao português, passando a denominar tais povoações de quilombos.

Juridicamente o termo é referido pela primeira vez em 1740, na carta resposta do Conselho Ultramarino ao rei de Portugal, quando quilombo é definido como "toda

\footnotetext{
${ }^{1}$ Para saber mais sobre a grande figura da Rainha Ginga ver Câmara Cascudo, "Made in África", SP: Global, 2001 e Carlos M. H. Serrano, "Ginga, A Rainha quilombola de Matamba e Angola", In.: Revista USP. Dossiê Povos Negros - 300 anos. SP: USP, CCS, 1989.
} 
habitação de negros fugidos, que passem de cinco, em parte despovoada, ainda que não tenham ranchos levantados e nem se achem pilões nele” (ALMEIDA, 1998:12).

Segundo o antropólogo Alfredo Wagner Berno de Almeida (1998), tanto os primeiros estudos científicos de Perdigão Malheiro (1866), como os estudos mais recentes de Clovis Moura (1996) desenvolvem pesquisas sobre o tema a partir dessa definição essencialista de quilombo que apresenta cinco elementos normativos: 1) a fuga; 2) a quantidade mínima de cinco escravos; 3) o isolamento geográfico; 4) a existência do rancho, ou seja, moradia e benfeitoria na terra; e 5) a presença do pilão, enquanto instrumento que transforma o grão colhido, representando a materialização simbólica da autonomia de produção e consumo.

Por esta perspectiva do termo, quilombo representa a reinvenção da África no Brasil, uma reprodução de seu modo de vida original e, portanto, a negação plena da subordinação do africano ao sistema colonizador e escravocrata. É a visão do quilombo como um projeto restauracionista, no sentido de que os fugitivos almejariam restaurar a África neste lado do Atlântico (ALMEIDA, 1998).

Os pesquisadores Arthur Ramos e Edison Carneiro são as principais referências dessa perspectiva aplicada ao tema. Em seus estudos, Ramos e Carneiro afirmaram que os negros escravos fugiam para o quilombo a fim de preservar a cultura que traziam da África, mantendo-a livre da ameaça de aculturação provocada pelos brancos. Assim, o quilombo seria uma alternativa para manter a identidade negra distante de uma suposta deformação, provocada pela contaminação de uma cultura branca. Interessante observar a ideia predominante na formação desse raciocínio de uma cultura pura e essencialista: o branco seria sempre formado por uma única cultura branca e o negro imutavelmente negro. Esses autores inspiraram uma concepção popular de quilombo enquanto comunidade isolada, preservada da contaminação de uma cultura branca.

Suas ideias, divulgadas nos anos de 1930 e 1940, foram amplamente combatidas pelos historiadores da década de 1960. Encabeçado por Clóvis Moura e Décio Freitas os autores dessa outra perspectiva de discussão do tema debatem sobre a rebeldia dos escravos e a existência dos quilombos embasando-se em teorias marxistas. Dentro de um contexto analítico de luta de classes, Moura e Freitas defenderam o Quilombo de Palmares como inerente à escravidão, ou seja, ele só existiu porque havia exploração de classes (FREITAS 1977; 1978; MOURA, 1981; 1993; 1996).

Por outro lado, na perspectiva da análise jurídica, o termo não é mencionado na legislação durante toda a República, pois se imaginava que os quilombos 
desapareceriam com a abolição da escravidão ou que não teriam razão de existência. Quando cem anos depois o termo ressurge pelo artigo 68 do ADCT da Constituição Federal de $1988^{2}$, já aparece com a conotação de remanescente, como vestígio do que fora, como resto e sobra de algo (ALMEIDA, 1998).

Para Wagner de Almeida (op. cit.), é fundamental a discussão sobre o que reconhecemos como "remanescentes das comunidades dos quilombos". Segundo ele, sendo o artigo 68 da Constituição um instrumento operacional, acionado para efetivar questões sobre a posse de terra e de legados patrimoniais colocados à ordem do dia constitucional, não pode estar restrito a um conceito de moldura passadista. Ao trabalhar com um conceito que remete mais ao passado ou ao que teria sobrevivido de um passado a ser preservado no presente por seu valor social e histórico, o artigo provoca o dissenso entre o entendimento do que existiu para o que se constitui hoje enquanto comunidade quilombola.

Reconhecer o caráter histórico dessas comunidades é reconhecer que existe um processo de transformação inexorável ao período histórico de mais de cem anos de regime Republicano. Com a retomada das reivindicações organizadas do movimento negro e dos movimentos sociais do campo, o único instrumento legislativo legal produzido pós-abolição que se refere ao patrimônio e ao território dos ex-escravos e seus descendentes revelou-se essencialista e ideológico. Mesmo assim, este termo da Constituinte vem sendo acionado pelos herdeiros das terras e grupos de negros marginais ao cativeiro do regime escravocrata, agora tendo no fator étnico mais um critério político-organizacional pelo qual trilham seu processo histórico, forjando sua identidade a partir da relação com o Estado (ALMEIDA, 1998).

Sendo assim, cabe aos cientistas que trabalham com essas comunidades autodenominadas quilombolas definir o que foi um quilombo e como esses assentamentos se constituíram. A partir deste parâmetro podemos estabelecer elementos comparativos entre os diferentes aspectos definidores das continuidades e das transformações ocorridas no tempo e no espaço, para definir as enquetes interpretativas e estabelecer possíveis estruturas para o reconhecimento dos atuais territórios quilombolas.

Em se tratando do trabalho do arqueólogo, partimos da perspectiva de que sua ciência, a Arqueologia, é acima de tudo uma ciência social plenamente capaz de

\footnotetext{
${ }^{2}$ Artigo 68 do Ato das Disposições Constitucionais Transitórias da Constituição Federal de 1988: "Aos remanescentes das comunidades dos quilombos que estejam ocupando suas terras é reconhecida a propriedade definitiva, devendo o Estado, emitir-lhes os respectivos titulos".
} 
estabelecer parâmetros comparativos para contribuir com esse entendimento da "história de longa duração" de diferentes populações, incluindo, os quilombolas (p. ex. HODDER, 1992; 1996:1-8; 2003:125-155; GNECCO, 1999; FUNARI \& ORSER, 2001; FUNARI \& FOGOLARI, 2005; FUNARI, 2008).

\subsection{Arqueologia da resistência escrava: uma abordagem da arqueologia da escravidão.}

Ao escolher trabalhar em território de comunidade quilombola, sabíamos que não seria possível realizar uma pesquisa arqueológica convencional. Estudos arqueológicos em comunidade quilombola no Brasil exigem um exercício teórico e metodológico que esteja em diálogo com as abordagens antropológicas, históricas, geográficas e arqueológicas contemporâneas.

Frente a esse desafio, desenvolvemos um trabalho etnoarqueológico em uma comunidade quilombola a partir do campo da arqueologia da escravidão, desde uma abordagem arqueológica que entende quilombo enquanto espaço emancipador. Desta forma, a arqueologia da resistência nos parece ser a abordagem mais adequada no campo da arqueologia da escravidão, pois permite pensar o Quilombo como espaço formado por ações de resistência e liberdade, herdadas por grupos de familiares que hoje se auto-denominam remanescentes de comunidades quilombolas.

Segundo Lúcio Menezes Ferreira (2011) foi nos Estados Unidos que a arqueologia da escravidão se institucionalizou em primeiro como um campo da arqueologia histórica. Não foi por menos que, no mesmo país, ocorreram os projetos sistemáticos e de maior alcance sobre as dimensões públicas desse campo de pesquisa arqueológico.

A ciência Arqueológica foi constituída nos Estados Unidos perante a dicotomia entre a Arqueologia Pré-histórica e a Arqueologia Histórica, onde a primeira se empenharia nos estudos das populações indígenas, ou ainda, do "outro", enquanto que a segunda se dedicaria ao período da colonização no qual se formou a nação, ou seja, a "nossa" história. Desde o início, os arqueólogos históricos desenvolveram escavações nas ruínas das treze colônias e nas plantations, priorizando como patrimônio da história nacional a monumentalidade das casas senhoriais e a vida luxuosa dos colonos. Quando, 
por volta da década de 1960, identificaram nos sítios das fazendas coloniais vestígios de cultura material escrava, dedicaram-se à tarefa inicial de descrição dos materiais encontrados. Acreditava-se que os escravos afro-americanos não possuíssem uma representação material de sua cultura. Esta pressuposição foi refutada com o desenvolvimento das pesquisas arqueológicas (FERREIRA, 2011).

Assim surgiu a arqueologia da escravidão. Enquanto parte da Arqueologia Histórica nos Estados Unidos, as fortuitas escavações no espaço das senzalas auxiliavam na descrição histórica das gloriosas fazendas coloniais contextualizando os vestígios referentes à escravidão. Entretanto, a partir de 1990 houve um aumento exponencial nos temas estudados pela arqueologia da escravidão, destacando entre estes a diáspora negra como o principal interesse do público em geral (ORSER, 1998).

Durante este período, com o surgimento das correntes teóricas de influência pósmoderna, os pesquisadores reconheceram as agências sociais dos sujeitos e passaram a investigar suas formas de atuação. As exigências das minorias sociais se destacam e deflagram as manifestações pelo seu reconhecimento, incluindo seus direitos históricos. Por outro lado, pesquisadores envolvidos em disciplinas formadas originalmente por práticas colonialistas são cobrados por diferentes setores da sociedade a reconhecer a produção do conhecimento como formadora de paradigmas e, por isso, como ação política inerente à prática científica (GNECCO, 1999).

Diante das novas perspectivas nas abordagens de pesquisas, surgem na arqueologia os estudos do registro arqueológico com o foco na tensão entre colonizador e colonizados (p.ex. RUBERTONE, 1994; SILLIMAN, 2001; SMITH \& WOBST, 2007; GNECCO, 2007). Entre estes estudos, Silliman (2001) chama a atenção para a necessidade de reconhecer estruturas e relações de poder no colonialismo, com o objetivo de identificar as agências dos povos não industrializados ${ }^{3}$, suas intenções, formas de resistências, tradições e distintas práticas pelas quais negociaram suas identidades e reconhecimento como coletivos diferenciados.

Ao examinar os estudos arqueológicos norte-americanos sobre "contato cultural", revelando as terminologias e interpretações distintas entre "contato" e "colonialismo", Silliman reconhece uma contradição existente nos estudos de

\footnotetext{
${ }^{3} \mathrm{O}$ conceito de povos não industrializados colocado por Silliman está associado à ideia de povos nativos que se encontram em oposição social à expansão ocidental movida pela exploração colonialista e capitalista da produção e acúmulo de capital. Ao longo desse trabalho, nos apropriamos desse conceito para nos referir aos povos nativos ou não do Brasil, que seguem a posição opositora a esse sistema de exploração e por isso estabelecem vínculos não monetários no local que ocupam.
} 
Arqueologia Histórica na América do Norte. Segundo ele, pesquisas sobre o período colonial, corriqueiramente utilizam o termo contato cultural para se referir às relações entre populações indígenas e europeias, mas nos estudos das fazendas escravocratas este termo não é empregado. O autor explica que os estudos sobre populações indígenas negligenciam a relação colonialista estabelecida entre diferentes níveis de poder político ao enfatizar encontros de curta duração. Com isso, a ideologia formada preserva traços culturais pré-definidos como marco de uma suposta inferioridade evolutiva natural. Por outro lado, os estudos das fazendas escravocratas privilegiam uma abordagem interpretativa embasada em zonas culturais e modelos de aculturação. $\mathrm{O}$ africano escravizado e levado à América deveria fazer parte da política de colonização. Isso implicava nas proibições das manifestações culturais africanas, em decorrência das táticas de opressão da cultura dominadora do senhor branco (SILLIMAN, 2001).

Entre os trabalhos de arqueologia histórica que estudam os vestígios e ruínas das antigas fazendas de escravos nos Estados Unidos, Caribe e Brasil ${ }^{4}$, é discutido o desafio arqueológico sobre a capacidade de identificar traços singulares que relacionem a cultura, a história e a dimensão material da resistência diária das populações escravas. Segundo Orser (1998), os estudos se deparam com o fato da natureza ambivalente da cultura material em questão. Pela acentuada abordagem interdisciplinar característica dos trabalhos de Arqueologia Histórica, os estudos apontam para o fato de que alguns artefatos eram usados de modo mutável ou ambivalente, o que sugere uma resistência escrava. Esses arqueólogos passaram a perceber que, contextualizados, tais artefatos poderiam ter sido utilizados tanto funcionalmente como simbolicamente. Ou seja, escravos podem ter usado alguns objetos aparentemente utilitários - como potes e cachimbos de barro - para promover coesão de grupo e identidade própria. Todos esses processos, entretanto, eram de extrema sutileza e exigem um denso exercício de interpretação da parte dos arqueólogos.

Nos Estados Unidos, algumas correntes do movimento negro têm empregado longos esforços, desde o começo da década de 1960, no intuito de revisar as formas

\footnotetext{
${ }^{4}$ São muitas as pesquisas de arqueologia histórica que trabalham com a cultura material da diáspora africana em fazendas escravistas. Entre os norte-americanos destacamos: Lee, 2008; Thomas, 1998; Yentsch, 1994; Orser, 1989. Na América Central podemos citar: Singleton 2001; La Rosa, 2005. No Brasil, além da bibliografia já citada, encontramos também Agostini, 1998; Symanski, 2007; Symanski e Souza 2007. Para outras referências bibliográficas e uma ampla abordagem do caminho histórico da chamada arqueologia da escravidão é preciso citar o trabalho de Lúcio Menezes Ferreira "Arqueologia da Escravidão e Arqueologia Pública: Algumas Interfaces”. In: Vestígios. Revista latino-americana de arqueologia histórica, v. 5, n.1, p. 7-23, 2011.
} 
institucionais de representação do negro no país. Em 1976 a Associação de Museus Afro-americanos foi formada, e sua militância e serviços resultaram na conquista do Centro para a História e Cultura Afroamericana, em 1995. O objetivo de ambas as instituições é trabalhar o modo como a participação dos afroamericanos é demonstrada na formação histórica do país pelas exposições e pesquisas formadoras de opinião pública (FERREIRA, 2011).

No Brasil, o Projeto Arqueologia da Serra da Barriga, elaborado pelo arqueólogo brasileiro Pedro Paulo Funari e o norte americano Charles Orser Jr, tendo em seguida a incorporação do inglês Michael Rowland e posteriormente sendo continuado pelo arqueólogo Scott Allen, foi um dos primeiros projetos a enfatizar a importância das pesquisas arqueológicas produzirem questionamentos quanto à interpretação e utilidade de sítios arqueológicos. Quando em 1992, Funari, Orser e sua equipe deram início ao trabalho arqueológico na Serra da Barriga, o lugar já era utilizado pelos ativistas negros desde 1970, por conta da reivindicação do dia 20 de novembro como dia da Consciência Negra em homenagem a Zumbi dos Palmares, líder do quilombo (FUNARI, 2005).

Segundo Funari (2005), a pesquisa teve estreito contato com a comunidade local e o movimento negro. Muitas das leituras produzidas pelos arqueólogos como, por exemplo, a hipótese de que o quilombo não teria sido um assentamento unicamente de negros, ou uma entidade cultural africana homogênea, provocou controvérsias dentro do movimento negro. Alguns construíam seus discursos sobre Palmares como um refúgio da africanidade negra no Brasil, resistindo à opressão branca. Outros aceitavam o quilombo como uma sociedade heterogênea, aberta, lutando contra a opressão. Neste último caso, o simbolismo de Palmares começa a ser redefinido e reconstruído.

Mesmo entre os arqueólogos que trabalharam em Palmares as leituras sobre os vestígios materiais encontrados não são unânimes. Segundo Aline Vieira de Carvalho (2005:15), cada arqueólogo propôs uma interpretação do que teria sido o Quilombo de Palmares segundo sua corrente teórica bastante específica. O projeto comprovou para os arqueólogos a importância de promover meios teóricos e metodológicos que viabilizassem o diálogo e as vias adequadas para acolher os conflitos dos diferentes discursos provenientes das diferentes correntes teóricas e grupos sociais, principalmente dos movimentos organizados que reivindicavam o uso de evidências arqueológicas no combate a discriminação e ao racismo. O trabalho sobre o patrimônio arqueológico de Palmares mostrou, assim, que os discursos não buscam o consenso, mas se pautam por 
interesses e experiências próprios de cada um dos grupos. Eles registram as múltiplas maneiras de interpretar o passado e situá-lo no presente (FUNARI, 2005).

Com base na experiência de pesquisa com a comunidade quilombola Saramaka, no Suriname, Richard Price (1996) sugere que ao invés de interpretarmos a história de Palmares segundo as necessidades ideológicas exclusivamente acadêmicas, seria mais propício e assertivo - produzindo mais conteúdo para ser aprendido - tentar ler Palmares na perspectiva das comunidades quilombolas atuais. Deste modo, tentaríamos apreender esses conhecimentos para direcioná-los às necessidades e ameaças que os descendentes dessas históricas comunidades continuam sofrendo ainda nos dias de hoje.

A noção de produção do passado apresenta-se de extrema relevância aos atuais debates arqueológicos, em especial pelo crescente interesse público nos temas, resultados, materiais e áreas de estudo das pesquisas arqueológicas. Claire Smith e Martin Wobst (2007) afirmam que esse despertar faz com que a prática arqueológica seja reconhecida como ato político.

Com esse movimento de reflexão sobre a prática científica, os arqueólogos passam a rever seus métodos e teorias, buscando a maior abertura da disciplina para uma reestruturação das relações de poder na formação e utilização do conhecimento arqueológico. Deste modo, diferentes abordagens arqueológicas como Arqueologia da Descolonização (GNECCO, 1999), Arqueologia da Resistência (LEONE, 1995; RUBERTONE, 1994), Arqueologia Comunitária (TULLY, 2007), Arqueologia Pública (MERRIMAN, 2004), Arqueologia Social (LUMBRERAS, 1974), Arqueologia do Presente (GONZALES-RUIBAL, 2008) surgem em diversas partes do mundo para discutir métodos e teorias que valorizem a diversidade cultural, com tentativas de efetivar a multivocalidade e as interpretações plurivocais do passado.

Esta diversidade teórica pode ser vista como o indício de um processo reflexivo que ainda necessita de uma clara estratégia de atuação. Gemma Tully (2007) reconhece a falta de uma estrutura teórico-metodológica ordenadora para a pesquisa arqueológica que a Academia Britânica denomina Arqueologia Comunitária. Segunda a autora, essa falta de estrutura teórico-metodológica explícita é justificada pela diversidade dos contextos nos quais as Arqueologias Comunitárias são praticadas.

Através de sete metodologias gerais propostas pelo Projeto Quseir, desenvolvido por Tully no Egito, são produzidas análises comparativas com os seis estudos de caso mais citados na literatura da Arqueologia Comunitária. O resultado desse estudo demonstra que fundamentos da abordagem comunitária, como a interação social, 
comunicação e reconhecimento de dificuldade, assim como o uso de entrevistas e histórias orais para prover mais diversidade cultural nas interpretações das evidências e enriquecer a construção da história de longa duração dos sítios são métodos compartilhados entre todos os exemplos analisados.

Desta forma, a autora reconhece que "um sistema fundamentalmente instintivo tem sido operado na prática da Arqueologia Comunitária. Apesar disso, uma metodologia mais focada e explícita se faz necessária ao caso desse tipo de pesquisa ter mais efetividade nas discussões da ciência arqueológica". E conclui: "Entretanto, as culturas são construídas e, sendo assim, estão eternamente abertas às negociações (Kreps, 2003:159), isso significa que o método colaborativo precisa ser flexível. Portanto, o método proposto precisa ser constantemente reavaliado (...)” (TULLY, 2007:179).

Na Austrália, a mudança na legislação no início deste século XXI concedeu todo o direito de decisão sobre as ações em terras indígenas aos próprios aborígines habitantes das terras. Portanto, agora são eles que controlam muitos aspectos das pesquisas arqueológicas em suas terras, incluindo também as publicações e disseminação dos resultados. Essa transferência do controle da produção do conhecimento arqueológico aos habitantes locais - os quais dificilmente compartilham dos mesmos interesses e percepções científicas - exige uma reformulação na metodologia teórica do trabalho de campo, da análise dos dados e da disseminação dos resultados.

Pela experiência etnoarqueológica entre os aborígines da região de BarungaWugullarr, no North Territory, Austrália, Claire Smith e Gary Jackson mostram que detalhes corriqueiros como a escolha de um informante local, por exemplo, é determinante para o resultado da pesquisa. Entre os aborígines australianos, os informantes e acompanhantes dos pesquisadores são escolhidos pelo próprio grupo e seguem critérios segundo o tema de pesquisa e a posição social do pesquisador em termos de idade, sexo e estado civil. Sendo assim, o modo como o pesquisador se coloca para a comunidade acaba estipulando qual será o informante que o acompanhará e, ao mesmo tempo, determinará a colocação do arqueólogo na própria comunidade aborígine e os tipos de informações que ele poderá ter acesso (JACKSON \& SMITH, 2007).

Quando afirmamos que o conhecimento arqueológico sobre o passado é construído e que o arqueólogo não é o único a participar da construção deste 
conhecimento, alargamos suas possibilidades. (SHEPHERD, 2003). O passado é reconhecido como um artefato cultural com muitas versões, cuja interpretação arqueológica é apenas uma destas versões. Junto ao grande movimento pós-moderno das minorias étnicas e movimentos sociais que clamam para ter sua alteridade reconhecida, outras vozes e versões históricas encontram crescente espaço de legitimação. A existência simultânea destas vozes é o que chamamos de multivocalidade (GNECCO, 1999:ix).

Nossa pesquisa etnoarqueológica explora as vozes sobre o passado, a partir das interpretações dos elementos presentes na paisagem cultural do território de um quilombo contemporâneo, situado no Baixo Vale do Ribeira: o Mandira. Desde uma perspectiva arqueológica, partimos do mundo material como elemento fundamental no processo de construção de identidades. Procuramos, assim, desvendar o modo como a construção do discurso histórico e arqueológico quilombola aciona a cultura material do seu território, incluindo os sítios, para legitimar e reproduzir as relações de pertencimento, tendo em vista a diversidade de interesses coletivos e formações políticas que a comunidade apresenta no presente e no passado (GONZALEZ-RUIBAL, 2008).

A temática da resistência, por sua vez, é abordada como elemento formador de uma identidade coletiva, manifestada nas formas mais diversificadas dentro das perspectivas arqueológica, antropológica e histórica. Neste sentido, adotamos a imagem do quilombo entendido como a maior expressão das ações de resistência ao sistema escravocrata (GUIMARÃES, 1995), para pensar nesse espaço como território de resistência, não de escravidão. Compartilhamos da opinião de que os "estudos em comunidade quilombola proporcionam assim, a melhor oportunidade para investir em importantes progressos na arqueologia da resistência escrava, em especial, e em entender a arqueologia da resistência em geral" (FUNARI \& ORSER, 2001:70).

Desta forma, a arqueologia da resistência escrava, que pretendemos seguir neste trabalho, tem o propósito de se alinhar com as perspectivas de uma arqueologia descolonizadora que assume a tarefa de reconhecer e legitimar as mais diversas percepções e interpretações do passado. Busca, com isso, a conotação de resistência que os discursos de formação da identidade quilombola apresentam e suas formas de representações materiais. 


\subsection{Etnicidade e a invenção do quilombola.}

$\mathrm{Na}$ busca por entender as particularidades históricas de tradições culturais em movimento, a concepção de etnicidade está além da definição de culturas específicas, sendo composta de mecanismos de diferenciação e identificação que são acionados conforme os interesses dos indivíduos, em consonância com o momento histórico no qual estão inseridos. Apresenta-se como processo pelo qual indivíduos e grupos se identificam dentro de situações específicas e para propósitos específicos, ou seja, uma categoria fluida pela qual as semelhanças relacionadas podem ser manipuladas simbolicamente para moldar uma identidade e uma comunidade (BARTH, 1997).

Os grupos têm sido estudados pelos antropólogos e sociólogos com base na autodenominação e definição pelos outros. Assim, o processo de construção da identidade étnica e a seleção de características culturais e linguísticas particulares, como símbolos relevantes de representações de identidade, ocorrem no contexto de interação social e envolvem a atribuição de identidade frente aos outros (CARNEIRO DA CUNHA, 1986). Alguns antropólogos ressaltam que em certos casos a construção ativa da identidade está embutida na negociação dos interesses econômicos e políticos, o que pode ser amplamente denominado de relações de poder (BARTH, 1997; JONES, 2005).

Admitindo este dinamismo na formulação, manutenção e transformação de identidades, a definição de parâmetros de comportamentos tradicionais e não tradicionais pode ser vista como a maneira cujas identidades são manipuladas. Terence Ranger (1997), em seu artigo “A Invenção da Tradição na África Colonial”, relata alguns aspectos das formas de como o florescimento das tradições inventadas na Europa nas últimas três décadas do século XIX influiu diretamente nas novas tradições surgidas na África. Neste mesmo período, os europeus finalmente conseguiram penetrar no continente africano, efetivando a colonização da África depois de quatro séculos. O autor demonstra como os colonizadores, movidos por sentimentos imperialistas, nacionalistas e militares, basearam-se nas tradições europeias inventadas tanto para definir quanto para justificar sua posição, e também para fornecer modelos de subserviência, nos quais foi possível incluir os africanos. A grande ambiguidade neste processo do colonizador, segundo Ranger, se traduz no modo como os europeus empregaram estas neotradições, pensando e valorizando costumes africanos enquanto conjuntos de regras e rituais rígidos que proporcionavam segurança em um momento de transformação por representar algo imutável. Como escreve o autor: 
"Quase todos os estudos recentes sobre a África pré-colonial do século XIX frisaram que, longe de existir uma identidade "tribal" única, a maioria dos africanos assumia ou rejeitava identidades múltiplas, definindo-se em certos momentos como súditos de um chefe, em outros como membros de certas seitas, em outros ainda, numa categoria profissional. Tais redes superpostas de associação e permuta estendiamse por amplas áreas. Assim as fronteiras da comunidade "tribal" e as hierarquias de autoridade nelas existentes não definiam os horizontes conceituais dos africanos" (RANGER, 1997:255).

Os costumes africanos não somente ajudavam a manter um sentido de identidade, mas também permitiam uma adaptação tão espontânea que passavam muitas vezes despercebidas. Através desta fluidez, o autor analisa como alguns grupos estabelecidos por fatores étnicos, de gêneros, de gerações ou de classe manipularam as neotradições europeias adquirindo um caráter peculiar e produzindo uma gama de novas tradições na África colonial.

Esta reformulação ou invenção das identidades nos parece um ponto central no contexto das relações entre os escravos africanos e seus descendentes no Brasil. Como já assinalado, os grupos que hoje são considerados remanescentes de quilombos se constituíram a partir de uma grande diversidade de processos históricos (GUSMÃO, 1996; ALMEIDA, 1998). Existem quilombos formados por heranças de ex-senhores de escravos, doações de fazendas, recebimento de terras como pagamento por serviços prestados ao Estado, pela simples permanência nas terras das grandes propriedades abandonadas pelos senhores de escravos falidos, ou pela compra de terras, tanto durante a vigência do sistema escravocrata, quanto após a sua existência (ALMEIDA, 1998). Completamente diferente da definição jurídica do termo que apresenta a imagem de um quilombo sem história, congelada no tempo, como remanescentes de um acontecimento do passado. Essa visão reduzida e retrógrada que a definição jurídica apresenta das comunidades negras reflete, na verdade, a "invisibilidade" produzida pela história oficial, cuja ideologia, propositadamente, negligencia os efeitos da escravidão na sociedade brasileira (GUSMÃO, 1996).

Além disso, os efeitos da inexistência de uma política governamental que regularizasse a situação desses grupos e/ou famílias negras após a abolição, reforçou a 
ignorância sobre os efeitos da contribuição escrava na formação histórica da nossa nação. O resultado dessa marginalização é uma herança de luta e resistência que é clamada a fazer parte da identidade desses grupos até os dias atuais, incluindo entre as estratégias de resistência a própria manutenção e (re)significação do sentimento de etnicidade (AGOSTINI, 2002). Assim, a (re)elaboração e manutenção destes sentimentos de etnicidade são dinamizados pelas redes de sociabilidade. A identidade cultural destes povos passa pela ativação de estruturas simbólicas conforme a necessidade e os interesses políticos e econômicos, somando às práticas de relação e interação com o meio ambiente e tendo o outro (indivíduo ou sociedade) como referência para a definição de sua alteridade e sua auto-denominação.

\subsection{Diferentes abordagens arqueológicas sobre comunidades quilombolas.}

Com diferentes categorias envolvidas, o tema quilombola revela questões extremamente contemporâneas. Os debates entre historiadores e antropólogos giram em torno dos conceitos e parâmetros teóricos na tentativa de definir as subjetividades que caracterizam esses coletivos, diferenciando-os de outros coletivos que procuram da mesma forma terem sua alteridade reconhecida. Os estudos arqueológicos que trabalham com quilombos e comunidades quilombolas perpassam o igual desafio de investigar os processos históricos de formação dessas comunidades, na tentativa de apontar elementos de permanências e transformações, que legitimam, no presente, a esses coletivos se auto-denominarem comunidades quilombolas.

Com tal desafio as dificuldades são instigantes. Toda a documentação histórica que menciona o termo quilombo foi escrita por uma elite letrada que almejava o extermínio ou a permanente invisibilidade destes grupos. A maioria da população da época era analfabeta de escrita e leitura, às vezes muito distante tanto física como subjetivamente, cuja sociabilidade podia ser muito diversa daquelas do escritor (FUNARI \& CARVALHO, 2005). A maioria dos registros escritos sobre o período da escravidão no Brasil foi destruído, incinerado sob a ordem do ilustre intelectual da elite nacional, Rui Barbosa. Além disso, durante todo o período colonial até as primeiras décadas da República, as manifestações rituais e costumes africanos eram proibidos no Brasil, pois não faziam parte do universo cultural europeu e não representavam a 
prosperidade nacional. Deste modo, assim como os objetos eram usados e percebidos de modo mutável ou ambivalente, o que sugere uma resistência escrava para promover coesão de grupo e identidade própria, os assentamentos de negros no Brasil também apresentam as mesmas propriedades.

Pesquisas dos últimos vinte anos vêm desconstruindo a imagem isolacionista dos quilombos. Historiadores e arqueólogos mostram através de pesquisas e estudos de caso específicos que a sobrevivência dos escravos fugitivos na sociedade brasileira se apoiou pela contradição do próprio sistema escravocrata, no qual, ao mesmo tempo em que esses fugitivos eram criminosos, interessavam economicamente à sociedade, fosse para complementar o abastecimento de insumos das cidades ou até mesmo para fomentar o comércio negreiro (BARBOSA, 1985; FUNARI,1991a; GOMES, 1996; REIS, 1996; GUIMARÃES, 1996).

Flávio Gomes (1996) ao estudar os quilombos da Baía de Guanabara, no Rio de Janeiro, estruturou as relações que os envolviam na teoria que chamou de "campo negro". Segundo ele, este espaço social tecido pelos negros transcende os limites traçados pela dicotomia senhor e escravo fugido, calcada na lógica normativa da relação entre autoridade e ilegalidade. Sob um pretexto comercial ou mesmo ideológico, os antigos quilombos configurados como uma espécie de "comunidade camponesa" paralela à sociedade envolvente, embora a ela articulada, constituíram uma relação com as cidades que lhes garantiam algum acobertamento e uma convivência relativamente pacífica com a sociedade escravista (GOMES, 1996).

Entre as pesquisas arqueológicas sobre o espaço afro-brasileiro, Agostini (2002) investiga nas fazendas do município de Vassouras, no interior do Rio de Janeiro, os espaços sagrados das chamadas comunidades de escravos. Com vistas ao entendimento do processo de sociabilização de africanos e afro-brasileiros numa sociedade escravista e entre estes e uma sociedade mais abrangente, a autora aponta para a possibilidade da existência de um espaço de liminaridade na sociedade da época. Construído fundamentalmente por afro-brasileiros, estes espaços liminares teriam sido formados por pequenas comunidades intermediárias entre as comunidades das senzalas e dos quilombos, na forma de uma classe campesina miscigenada, que vive dos recursos da floresta estabelecendo relações comerciais e religiosas com os povoados do entorno. Teria, assim, constituído uma classe de antigos escravos fugidos, abandonados pelo Estado, não sendo oficialmente reconhecidos por seus mecanismos sociais. Aos poucos, essas "comunidades do mato", como são denominados, encontravam espaços, sofriam 
pressões, institucionalizavam situações, que proporcionaram a possibilidade delas tecerem amplas redes de sociabilidade, permitindo sua permanência e presença na sociedade.

Outro estudo arqueológico sobre assentamentos quilombolas é a dissertação de João Rosa (2008) sobre os quilombos do Vale do Guaporé, ao redor do município de Vila Bela da Santíssima Trindade, no Mato Grosso. Segundo o autor:

\begin{abstract}
"Parece haver uma confusão entre diferentes assuntos: 1) terras de remanescentes de quilombos e 2) indenização por serviços prestados por seus ancestrais (...) Conquanto os espaços de trabalho, dominação e poder dos escravizadores fossem a base de sua própria negação pelos trabalhos escravizados, a transformação atual naquilo que expressava o seu oposto reafirmação de domínio sobre sua força de trabalho e de liberdade parece não dar conta do sentido histórico que representaram as ações dessa negação. O entendimento de que esses espaços também são quilombos evidencia minimamente uma manipulação daquilo que simbolizaram as variadas resistências contra a opressão no período da escravização, ou, no pior das hipóteses, um parco domínio e até mesmo um desconhecimento do conceito em questão" (ROSA, 2008:163).
\end{abstract}

Como veremos mais pormenorizadamente durante os próximos capítulos, o modo como os indivíduos e grupos interagem com o ambiente e os vestígios arqueológicos presentes neste ambiente, manipulando, forjando, ressignificando e criando símbolos referentes a sua identidade, fornece uma importante chave para entender os aspectos sociais de formação das complexas redes de interação das comunidades quilombolas no passado e no presente. Relativizar e (re)significar o termo quilombo exige que o arqueólogo assuma o desafio de trabalhar com categorias sociais extremamente mutáveis e fluidas como artefato, identidade e território.

Neste sentido vemos a afirmação de Wagner Almeida (1998:16), quando escreve:

“(...) necessário que nos libertemos da definição arqueológica, da definição histórica strito senso e das outras definições que estão frigorificadas e funcionam como uma camisa de força. (..) a relativização desta força do 
inconsciente coletivo nos conduz ao repertório de práticas e as auto definições dos próprios agentes que vivem e construíram estas situações hoje denominadas como quilombos".

Limitar o vetor da negação dos escravos ao espaço de trabalho, dominação e poder dos senhores negligencia o fato dos mesmos terem, em alguns casos, permanecido nas fazendas escravocratas após o abandono dos senhores, ou, em outros casos, ter ocorrido a compra das terras dos senhores falidos pelos seus próprios escravos. Do mesmo modo, achar que as ações e símbolos da resistência escrava projetadas no espaço não dão conta de processar a transformação de um espaço de repressão em um de libertação, ou seja, que os atuais quilombos não podem estar assentados no mesmo espaço das antigas fazendas escravistas é negar todas as teorias de reapropriação e ressignificação dos espaços. Fato este que, em nosso entendimento, é fundamental para entender as próprias táticas de resistência africana e afro-brasileira à escravidão. A transformação, ou até mesmo a dominação dos espaços escravizadores em espaços emancipadores faz com que estes lugares possam ser entendidos como territórios de resistência.

Para Sidney Chalhoub (1990) a participação dos próprios negros na resistência ao cativeiro e luta pela liberdade foi decisiva para o fim da escravidão. Nesse sentido, o quilombo configura-se como a expressão máxima das lutas pela desestruturação do sistema escravista, cuja formação foi a estratégia encontrada para quebrar efetivamente as relações de dependência e de dominação. Foi o momento em que o escravo, para recriar sua identidade, cria um território de liberdade.

O Projeto Fronteiras Ocidentais, desenvolvido pela empresa Zanettini Arqueologia, com subsídio da Lei de Incentivo a Cultura do Mato Grosso, coordenado pelo arqueólogo Paulo Zanettini, promoveu entre outras ações a Expedição aos Territórios Quilombolas do Vale do Guaporé, em 2007. Somados os dados arqueológicos e etnoarqueológicos levantados nas investigações iniciadas desde 1989, vislumbra-se o fato de que o núcleo urbano de Vila Bela da Santíssima Trindade foi palco de uma cidade quilombo. Segundo o Relatório Final da Fase 4, volume IV do projeto, após a transferência do poder político do estado para Cuiabá, em 1860, a cidade sofreu gradual abandono da camada branca dominante. Esse processo culminou na confirmação de uma comunidade negra na sede do município, composta por negros livres, escravos abandonados pelos senhores e escravos aquilombados que retornaram à 
cidade. É provável que a partir deste momento a cidade se transformou em um centro agregador das comunidades quilombolas que ocupavam o Vale do Guaporé (ZANETTINI, 2007:23-25).

Ainda segundo o mesmo relatório, os quilombos do Vale do Guaporé na época da colônia eram miscigenados entre negros e índios da região. Esse foi o caso do quilombo Piolho, que teria se formado desde os primeiros tempos da exploração das minas de Guaporé. Situado no norte da Vila Bela, à beira do rio Piolho, o quilombo foi batido pela primeira vez em 1770, por uma bandeira que capturou 79 negros e 30 índios. Ele foi destruído, mas logo depois reconstruído pelos membros que haviam conseguido fugir. Quando quinze anos depois nova bandeira abateu o mesmo quilombo, foram capturados 59 quilombolas dos quais existiam negros, índios e caburé ${ }^{5}$ nascidos no próprio aldeamento (ZANETTINI, 2007:21-22).

Outro estudo sobre quilombo já comentado nesse trabalho, é o Projeto Arqueologia da Serra da Barriga, em Alagoas, local onde se encontrava a maior área do Quilombo de Palmares. Com o objetivo de localizar e evidenciar aspectos da vida sóciopolítico-cultural de Palmares, o projeto logrou duas etapas de campo iniciais no ano de 1992 e 1993, com a coordenação dos professores Pedro Paulo Funari e Charles Orser Jr. e a participação do professor inglês Michael Rowland. Posteriormente, no ano de 1996, o assentamento foi escavado pelo norte-americano Scott Joseph Allen, mas, sem a participação dos outros três pesquisadores.

Segundo Carvalho (2005), as primeiras etapas interventivas nos sítios arqueológicos resultaram em diferentes interpretações sobre o modo como esses aquilombados foram capazes de organizar um assentamento que concentrou todo tipo de camada social excluída do regime colonial. Para Funari (1996a;b;d), o caráter original e sincrético dessa sociedade, teria se constituído dentro de um grande sistema regional, como uma cidade não isolada, mas compondo uma cultura e identidade, que interagiam com colonos e nativos. Dinamismo similar é sustentado pelas interpretações de Orser (1996), quando afirma que o quilombo estaria integrado ao "mundo moderno, capitalista, europocêntrico, e marcado pelo colonialismo global”. Assim, Palmares

5 Segundo o Dicionário do Aurélio Online: Dicionário da Língua Portuguesa. Site: http://www.dicionariodoaurelio.com/Cabure. "SIGNIFICADO DE CABURÈ - s.m. Bras. mestiço de negro com índio; cafuzo./ Caipira, matuto./ Sertanejo./ Vaso de feitiço./ Sujeito feio e melancólico./ Indivíduo que só sai a noite; coruja./ Ave da família dos estrigídeos, noturna, que é uma espécie de mocho". 
teria mantido relações estreitas com os colonos regionais, não apenas comerciais, mas também na esfera particular da vida cotidiana, pois compartilhavam de uma identidade mais próxima a dos palmarinos do que com a dos latifundiários ou as elites locais.

Por sua vez, Scott Allen (1998) decifra Palmares a partir do processo da etnogênese e da identidade multiétnica: os quilombolas teriam criado, em um ambiente natural e social desconhecido, uma nova cultura e identidade. Suas roupas, nomes, utensílios, dentre outras expressões culturais (materiais ou não), eram compostos a partir da articulação de elementos tradicionais e novos. Por fim, Michael Rowlands (1999) define Palmares como detentor de uma estrutura plural. Nessa linha argumentativa, o quilombo não seria constituído por uma sociedade multiétnica e harmoniosa. Ao contrário, se configuraria como uma sociedade muito próxima à existente no mundo colonial da época. Haveria distinções entre a elite palmarina e os outros habitantes dos quilombos; em outras palavras, distinções de classe, e diferenciações determinadas por gênero e etnia.

Assim, os estudos da cultura material e das estruturas evidenciadas forneceram indícios suficientes para afirmar (entre todas as interpretações, talvez seja a única conclusão unanime) que o assentamento de fugitivos abrigou não apenas negros, mas também índios fugidos da escravidão, mulçumanos, judeus, mulheres acusadas de bruxarias e todas as figuras sociais excluídas e perseguidas pelas autoridades do Estado (FUNARI, 1996d).

Importante salientar que os estudos arqueológicos em contextos como os de comunidades quilombolas devem atentar para os vestígios arqueológicos na formação de palimpsestos de ocupação. Como buscaremos demonstrar mais adiante, em muitos casos, faz parte da história dos territórios quilombolas as diversas ocupações, reocupações e abandonos territoriais através do tempo por sociedades culturalmente diferenciadas, ou ainda, de diversas maneiras pela mesma sociedade durante um determinado período, sendo que ambas as possibilidades podem resultar em conjuntos de vestígios arqueológicos diversos e dispostos espacialmente de modo muito complexo. Consequentemente, estudados enquanto palimpsestos de ocupação, os territórios quilombolas permitem pensar contextos de reutilização de estruturas e artefatos (PANJA, 2004:112).

Deste modo, o abandono da imagem dos quilombos propagada pelo senso comum, de comunidades homogêneas, formadas por escravos fugidos, assentados em locais isolados de difícil acesso e refugiados da sociedade escravocrata, vivendo na 
labuta pela subsistência - representada pela cultura material do pilão - resulta, talvez, no maior desafio para a arqueologia da resistência escrava, que trabalha com vestígios da cultura material. Por isso, trabalhos que pensem em práticas descolonizadoras e inclusivas da arqueologia em território quilombola, como forma de pensar as trajetórias históricas de formação dessas comunidades, apresentam-se relevantes no cenário contemporâneo da disciplina.

\subsection{Etnoarqueologia e Arqueologia do Presente.}

Estudos etnoarqueológicos em consistente diálogo com as atuais teorias científicas exigem, entre outras coisas, que sejam expostas questões políticas envolvidas aos temas abordados, provocando um posicionamento crítico e ético do pesquisador. Para isso, adotamos a perspectiva teórica da Arqueologia do Presente, descrita por Gonzalez-Ruibal (2009), para pensar no desenvolvimento do trabalho de pesquisa etnoarqueológico na comunidade quilombola do Mandira.

Como sabemos, a Etnoarqueologia surgiu com o advento da Arqueologia Processual na década de 1960, quando Binford (1968) começou a discutir de maneira sistemática o uso de dados etnográficos para os trabalhos arqueológicos. Posteriormente, os arqueólogos processualistas desenvolveram o campo de pesquisa e definiram as bases metodológicas da etnoarqueologia a partir dos pressupostos processuais. Neste sentido, a etnoarqueologia transformou-se em uma das mais importantes sub-disciplinas da Arqueologia por promover uma base de dados etnográficos arqueologicamente relevantes para desenvolver modelos interpretativos sobre os processos culturais de formação do registro arqueológico (KENT, 1987; DAVID \& KRAMER, 2001; TRIGGER, 2004; POLITIS, 2004; SILVA, 2009).

Desta forma, a etnoarqueologia surge pela valorização dos estudos etnográficos com um olhar arqueológico para explicar a formação do registro arqueológico. Os arqueólogos que seguem esse campo de pesquisa procuram formular generalizações interculturais sobre a relação dos homens com o mundo material e procuram evidenciar os resultados materiais dessa relação (POLITIS, 2004).

Entretanto, no começo da década de 1980, a etnoarqueologia já ampliava seu enfoque para além da abordagem processualista. Guiada pelo pós-processualismo, a 
etnoarqueologia expandiu seu campo de interesse buscando discernir a maior complexidade das relações existentes entre os correlatos materiais e os aspectos cognitivos, sociais e ideológicos dos grupos sociais. Dentro do novo marco conceitual da arqueologia, a etnoarqueologia passou a investigar os aspectos superestruturais da cultura material nas sociedades. Desta maneira, o enfoque voltou-se para o estudo dos significados simbólicos e as dimensões não funcionais da cultura material dentro da rede de relações sociais. Assim, os estudos etnoarqueológicos tomaram um rumo hermenêutico (POLITIS, 2004:89-90).

A partir dos debates que se desenrolaram entre a Arqueologia Processual e Pósprocessual, torna-se crescente a diversidade de percepções e leituras sobre os dados arqueológicos. Aumenta expressivamente o número de pesquisas etnoarqueológicas, contemplando uma diversidade de contextos sociais, com diferentes tipos de abordagens (DAVID \& KRAMER, 2001). O passado começa a ser percebido a partir de uma realidade mais complexa, que incluem as percepções do próprio pesquisador e os interesses do presente (HODDER, 1982a; 1986). Isso torna cada vez mais evidente que os problemas arqueológicos não podem ser solucionados apenas por um ou outro referencial teórico (TRIGGER, 2004).

No início do século XXI, os debates arqueológicos incorporam as questões de dimensão política. Essa tendência se faz explícita principalmente através dos trabalhos etnoarqueológicos (POLITIS, 2004:91). No centro desse debate político sobre a prática descolonialista no desenvolvimento das pesquisas arqueológicas, Gonzalez-Ruibal (2003:12) define etnoarqueologia como:

“o estudo arqueológico de sociedades geralmente pré-industriais, com o objetivo de produzir uma arqueologia mais crítica e menos restringida culturalmente, de gerar ideias que favoreçam o debate arqueológico e de contribuir para o conhecimento das sociedades com as quais se trabalha, tendo em conta suas tradições, ideias e pontos de vista".

Empenhado na sofisticação dos estudos de sociedades do presente, GonzalezRuibal (2008) debate os problemas epistemológicos e éticos que os estudos etnoarqueológicos enfrentam. $\mathrm{O}$ primeiro refere-se à realidade de que nenhum arqueólogo se utiliza dos trabalhos etnoarqueológicos para compreender o registro arqueológico. No caso dos arqueólogos processualistas, voltados ao estudo dos padrões 
tecnológicos da cultura material, o autor sugere que isso se deve ao fato da opinião comum supor que diferentes especializações vinculadas à disciplina promovem o refinamento da abordagem arqueológica. Pela arqueometria, por exemplo, poderíamos controlar variáveis de procedimentos físico-químicos da fabricação de objetos, que minimizam a necessidade de observar os procedimentos específicos dos artesãos tradicionais.

Por outro lado, quando se trata de questões mais específicas do universo simbólico ou sociopolítico, os pós-processualistas preferem recorrer a pesquisas que revelam aspectos amplos da cosmologia dos grupos estudados. Com essa exigência, os arqueólogos buscam comparações com estudos históricos, antropológicos e etnohistóricos, que apresentam uma visão holística da vida social de comunidades específicas ou aspectos específicos da vida social de diferentes grupos. Entretanto, o autor alerta para o fato de que os trabalhos dessas disciplinas apenas mencionam alguns aspectos da cultura material. A materialidade presente nos contextos das sociedades estudadas não é o ponto de partida e tão pouco o ponto central das pesquisas. O que se torna também uma das críticas dirigidas à arqueologia pós-processual: a ênfase nos sistemas sociais faz com que negligenciem os aspectos mais puramente materiais da existência humana.

Além do que, o fato das variáveis dos processos de fabricação dos objetos serem mais precisamente controlados por experiências em laboratório do que pelos trabalhos de campo está relacionado, entre outras coisas, pelas barreiras de linguagem que envolve a prática de campo etnoarqueológico. A vivência dos arqueólogos com os grupos sociais estudados implica em longos períodos de aprendizagem da comunicação local e representações simbólicas em torno do mundo material. Compreender estas representações implica no melhor entendimento das variáveis presentes no processo de fabricação dos objetos.

Esse debate nos leva a outro questionamento enfrentado pela etnoarqueologia, neste caso de caráter ético: é lícito pesquisar as sociedades tradicionais do presente apenas como objetos de estudos para melhor compreender o passado? No mundo globalizado, onde a prática democrática é valorizada, o cientista é levado a rever sua postura aristocrata de detentor do conhecimento. Como vimos, ao arqueólogo é exigido rever sua postura colonialista de detentor do conhecimento sobre o passado, construída no século XIX. Neste sentido, Gonzalez-Ruibal (2008:19) propõe que os arqueólogos "estudem os grupos com que trabalhamos com um fim em si mesmo, mais do que como 
uma fonte de analogias". Trata-se, em certa maneira, de resgatar a dimensão antropológica da arqueologia. Assim, ao invés de se fazer uma etnografia do passado (o que é impossível, pois etnografia envolve observação do tempo presente), o autor propõe que seja produzida uma Arqueologia do Presente. Desde uma perspectiva arqueológica, que parte do mundo material, a Arqueologia do Presente produz estudos arqueológicos do mundo contemporâneo, que nos permite compreender melhor as sociedades vivas.

Deste modo, Gonzalez-Ruibal apresenta três pontos chaves dos princípios teóricos e metodológicos da Arqueologia do Presente que, segundo ele, se diferencia da abordagem etnoarqueológica:

Primeiro, a Arqueologia do Presente não está preocupada em elaborar modelos e padrões sobre o comportamento Humano que servem como parâmetro comparativo para se pensar a formação do registro arqueológico. O objetivo final da Arqueologia do Presente não é o analógico - apesar de seus resultados poderem ser aplicados desta forma em outros trabalhos comparativos. Antes disso, procuramos entender o modo como os contatos culturais ocorrem, as mudanças sociais são conduzidas e a noção do hibridismo emerge. $\mathrm{O}$ arqueólogo do presente parte da consciência de que os povos que estudam são comunidades contemporâneas que não permaneceram isoladas e inalteradas no tempo. São coletividades formadas por agentes de seus destinos e, por isso, dotadas de uma noção própria de tempo histórico que envolve relações diversas e conhecimentos aplicados. A Arqueologia do Presente constrói uma pesquisa que leva em conta a complexidade de interações culturais de um povo, entre diferentes necessidades e formações políticas no presente e no passado, facilitando as relações étnicas ou criando barreiras (GONZALEZ-RUIBAL, op cit:19).

Como discutimos anteriormente, as comunidades quilombolas no presente, por mais arcaicas e exóticas que possam vir a ser interpretadas pelo senso comum denominadas por termos como comunidades remanescentes de quilombo - não foram formadas por uma cultura insular durante mais de cem anos. Pela postura crítica da Arqueologia do Presente tomamos como parte dos objetivos da pesquisa na comunidade quilombola dos Mandira "abordar questões relacionadas com a globalização, a violência politica, as interferências estatais" (GONZALEZ-RUIBAL, op. cit:18) que fazem parte do processo de formação do território dessa comunidade auto-denominada quilombola. Trata-se de entender, assim, as possibilidades de respostas do comportamento humano frente às exigências do modo de vida contemporâneo 
globalizado e que apontam para as mudanças e continuidades que se processam na dinâmica de formação do território quilombola dos Mandira.

O segundo ponto é que a Arqueologia do Presente "estuda potencialmente todo o mundo atual: tanto sociedades não modernas como capitalistas. Não estabelece uma distinção rígida entre nós e os outros” (Gonzalez-Ruibal, op. cit:20). Respeitando os diferentes discursos, procura entender os diferentes contextos sociais a partir do mundo material. Deste modo, a Arqueologia do Presente adota uma postura política à medida que procura estabelecer relações menos assimétricas com os povos com que trabalha. Evita assim, de um ponto de vista Ético, converter os povos com que trabalha em meros objetos neutros de analogias arqueológicas.

Para isso, utilizamos como método de pesquisa de campo a investigação participativa e democrática da arqueologia colaborativa. Isso implicou, primeiramente, na apresentação formal do projeto de pesquisa à comunidade e na consulta sobre sua importância e seus interesses no desenvolvimento da pesquisa. Para além disso, não buscamos o consentimento e/ou convencimento da comunidade sobre a relevância da pesquisa, mas o engajamento crítico e a interação durante todo o processo de construção do conhecimento arqueológico. Na tentativa de superar o modelo colonialista tradicional da prática arqueológica, investimos na incorporação de perspectivas culturais plurais para a investigação e interpretação do passado. Essa prática busca diversificar as vozes interpretativas sobre o passado e os significados do registro arqueológico, construindo uma educação mútua entre arqueólogos e comunidade (SILVA, 2009:208).

Por último, o terceiro ponto específico da Arqueologia do Presente que pretendemos adotar em nossa pesquisa, "não contempla uma distinção drástica entre passado e presente: em vez de considerar um a serviço do outro, como faz a etnoarqueologia, [essa nova perspectiva científica] acredita que ambos, passado e presente, estão intrinsecamente unidos” (GONZALEZ-RUIBAL, op. cit:20).

Como já abordamos anteriormente, muitos trabalhos com comunidades não industriais demonstram que a história é acionada como parte do processo de vida dessas comunidades que fazem do passado uma referência para o presente e da paisagem uma parte da sua memória. Como vimos, podemos pensar então, em histórias construídas a partir de questões e interesses impostos pelo presente. É essa questão que trataremos agora, expondo o método de investigação adotado. 


\subsection{Narrativas e história oral como fontes da memória.}

A fim de alargar as possibilidades de construção do conhecimento arqueológico utilizamos das narrativas e história oral na pesquisa etnoarqueológica como fontes de análises e instrumento de interpretaçãos sobre o processo de formação do território Mandira. Valorizando as várias narrativas sobre o passado, procuramos investigar o modo como os quilombolas se apropriam dos elementos do seu território, incluindo os sítios arqueológicos, formando uma identidade compartilhada entre os Mandira.

Como um dos métodos de produção do conhecimento historiográfico de comunidades afro-americanas a história oral tem sido utilizada desde o começo do século passado nos Estados Unidos. Segundo Paul Thompson (1992:136-137), uma das autobiografias coletivas mais importantes até hoje publicada é a transcrição das entrevistas com antigos escravos das grandes fazendas e com seus dependentes, colhidas nas décadas de 1920 e 1930. Como a história só interessa quando é utilizada para justificar ou negar os reclamos da supremacia dos brancos, esses documentos ficaram sem ser utilizados pelos historiadores por mais de três décadas. Isso foi corrigido agora pela publicação integral das narrativas dos escravos, em dezoito volumes de título The American Slave: A Composite Autobiography, organizados por George Rawick.

Nos Mandira existe um trabalho de levantamento e registro da história oral coordenado pelo professor Dr. Antônio Carlos Diegues. As entrevistas foram realizadas com Francisco de Sales Coutinho, também conhecido como Chico Mandira e sua esposa, Irene Cândido Mandira Coutinho. A entrevistadora foi a socióloga Wanda Terezinha Passos de Vasconcellos Maldonado e ocorreu em 06 de maio de 2002. As entrevistas foram publicadas como capítulo titulado "Mandira: nome de terra, nome de gente", do livro Enciclopédia Caiçara: História e Memória Caiçara. Vol. IV, Editora Hucitec - NUPAUB-CEC/USP, São Paulo, 2005, organizado por Carlos Diegues. Elas abordaram diversos temas como a origem do quilombo, os trabalhos, a RESEX, religião, festas, as lutas, as mudanças e outros assuntos também explorados nesta pesquisa dissertativa.

Em nossa perspectiva de trabalho entendemos história enquanto termo sujeito a influências de seu tempo e contexto social. De forma geral, podemos dizer que a história é contada de acordo com seu narrador, ou seja, a construção histórica está sujeita as expensas de seu tempo e local e ao conhecimento e interesse de seu autor: seja indivíduo ou coletivo. 
De forma parecida vemos a maioria das comunidades não industrializadas, que fazem do passado uma referência para o presente. Assim como a identidade não é uma quintessência imanente e imutável, imune às transformações, convêm ter presente que a memória é tratada como um processo historicamente mutável, de um trabalho, e não de algo objetivado ou de um pacote fechado de recordações induzidas (MENESES, 2007: 47-48). A história para esses grupos é parte do processo vivido e a paisagem do seu território é a referência de sua memória (ANSCHUETZ et all, 2001:190).

Não existe memória espontânea. A memória precisa ter raízes em objetos ou lugares concretos e precisa ser ativamente relembrada e mantida por aniversários e celebrações. Monumentos e a cultura material de forma geral atuam como ferramentas culturais no processo de ativar a lembrança ou o esquecimento. Desse modo, o patrimônio é constituído e dialeticamente agencia a organização pública e a memória histórica (SMITH \& WATERTON, 2011:47).

Através da memória, o território quilombola torna-se um espaço investido pelo tempo, mas não um tempo cronológico. Trata-se de uma temporalidade particular, historicamente constituída que se revela através das narrativas históricas e das histórias de vida que unificam a origem e o destino de cada um e de todos com relação ao território em que vivem e viveram seus antepassados (GUSMÃO, 1995:119).

Segundo Gusmão (op. cit:122) é no movimento vivo das inter-relações sociais que as histórias e narrativas são (re)visitados e as tradições (re)significadas, instrumentalizando seu mundo no conflito com o outro. A validade destas fontes parte da premissa de que todas elas constituem-se em suas funções originais de transmitir e preservar a memória e o sistema de conhecimento local. Nesse sentido as narrativas históricas proporcionam a fusão entre passado e presente, redimensionando o tempo e gerando o sentimento de pertencimento. O modo como isso acontece é o foco desse trabalho.

Ao formular um livro dividido em duas partes que se desenvolvem simultaneamente, sendo uma parte as narrativas históricas dos Saramakas do Suriname e outra parte os comentários do escritor/organizador do livro sobre as narrativas selecionadas, Richard Price (1983:5) salienta que as histórias e tradições são o modo como os Saramakas transformam o passado geral (todas as coisas que aconteceram) em um passado significativo, com narrativas selecionadas. $\mathrm{O}$ autor define história como sendo "uma seleção radical do imenso rico moinho de atividades humanas do passado". 
Para Muniz Sodré (1988:154) a fusão entre passado e presente operada pela temporalidade histórica comanda a possibilidade de ação coletiva com base na tradição. A razão está no fato da tradição, ao mesmo tempo em que reflete uma relação subjetiva com o passado, mostra o passado, não como o retorno ao fato que passou, mas como meio de afirmação coletiva e pública no presente. Deste modo, segundo Muniz Sodré, opera a forma de comunicação no tempo e, concomitantemente, o conjunto de saberes que se transmitem entre gerações.

Na maioria das sociedades quilombolas a palavra escrita é quase inoperante, principalmente entre os mais velhos. A palavra escrita é dotada não da força vital própria da oralidade, mas de um poder nela investido e que o quilombola não possuía. Por isso, a maioria das comunidades não dispõe de documentos comprobatórios de seus direitos, ou simplesmente não dão importância a esses documentos, e o "outro" toma o fato como meio de expor-lhe a negatividade de seu espaço e condição no mundo. A terra torna-se o elemento central desse processo, posto que o documento escrito destitui seu estado de pertencimento e atribui ao outro, até então distanciado, o direito de proprietário. Sem a validade da sua palavra e sem acesso à palavra escrita as comunidades quilombolas tornam-se muito vulneráveis às discriminações, ameaças e explorações (GUSMÃO, 1995:126).

$\mathrm{Na}$ particular história dos Mandira a escrita aparece na forma de documento de demarcação do território exigido por eles desde o começo do século XX. Entretanto, como veremos, mais do que estabelecer a delimitação de fronteiras, o documento tornou-se uma fonte histórica da territorialidade dos Mandira. A maioria dos Mandira desconhecem o documento que está arquivado na Oficial de Registro de Imóveis e Títulos e Documentos da sede Comarca de Cananéia, entretanto, contam as histórias de conflitos existentes entre João Vicente Mandira e o Coronel Cabral, tempos em que João Mandira se deslocava até Santos de canoa a remo para resolver questões ligada a terra.

Entre a oralidade e a escrita estão em jogo os processos que legitimam as inscrições dos indivíduos e grupos em seu universo particular, cuja relação é dada no âmbito político e econômico que envolve o mundo do "Eu" e o mundo do "Outro". (GUSMÃO op.cit.:127). Segundo Meyhi (2005), a história oral é capaz de dar voz a setores antes inaudíveis por outros documentos. Por meio da história oral, minorias culturais discriminadas têm encontrado espaço para abrigar suas palavras, dando sentido social a situações vividas sob diferentes circunstâncias. A história oral busca (re)inserir 
o indivíduo no contexto social, e, ao logra-lo, também contextualiza e mantêm a memória de patrimônios culturais e arqueológicos, que de outra forma correria o risco de desaparecer.

Entre os trabalhos de etnoarqueologia que utilizam a história oral e as narrativas tradicionais como fontes de informações, destacamos o trabalho de Stewart, Keith e Scottie no baixo rio Kazan, no norte do Canada, entre os povos Inuits. Para esses autores, histórias e contos consistem em narrativas tanto reais quanto imaginárias, sendo que, a negociação entre crença e dúvida acontece através das cerimônias e tradições. Deste modo, os pesquisadores trabalham com as interpretações arqueológicas enriquecidas pelos conhecimentos indígenas, incluindo a tradição e história oral, cujas narrativas informam rigorosamente sobre os registros nas paisagens incluindo os sítios e vestígios arqueológicos (STEWART et all, 2004:185).

Nosso trabalho desenvolvido com os Mandira seguiu o mesmo método de coleta e análise dos testemunhos dos relatos orais, aplicados no intuito de desvendar os processos pelos quais tornam-se memória em seu sentido social (MONTENEGRO, 2007). As narrativas dos Mandira sobre o passado estruturam as relações deles com os elementos da paisagem territorial no presente, sendo extremamente relevantes ao gerenciamento de práticas com a terra, assim como às relações que estabelecem com os patrimônios culturais e arqueológicos no território. Portanto, como metodologia de pesquisa foi realizado o registro, análise e interpretação das histórias orais e das outras formas de narrativas e relatos históricos praticados pelos Mandira, para entender sua territorialidade e paisagem, com especial atenção às interpretações que envolvem o patrimônio arqueológico.

Com isso, os relatos orais foram coletados de três maneiras: no início da pesquisa, demos atenção especial ao registro de informações que conduziram ao reconhecimento do gênero vivido, como forma de apreensão dos significados que os atores fornecem às experiências. Caracterizou-se em um trabalho etnográfico que objetivou nesse primeiro momento a familiarização da linguagem e a percepção do olhar local sobre a formação da paisagem. Para isso, realizamos conversas correntes, como elemento constitutivo da observação participante da rotina local. Nesse momento, os registros foram orientados pelas diferentes nomenclaturas empregadas aos objetos, elementos da fauna e flora, lugares, eventos e festas, atos e práticas específicas, ou nomenclaturas que dizem respeito a algum momento histórico específico ou elemento 
subjetivo que faz parte da cosmologia dos Mandira. Essa estratégia também orientou o registro dos primeiros relatos orais apresentados fortuitamente pelas exigências das atividades experimentadas e das conversas ocorridas no convívio do etnoarqueólogo com os membros da comunidade.

Em seguida, buscamos coletar informações específicas sobre ofícios e lugares. Após um primeiro momento de apresentação, reconhecimento e familiaridade, o pesquisador adquiriu mais liberdade de mobilização dentro da comunidade pela interação com as pessoas do local. Deste modo, a linguagem se tornou mais fácil e as informações obtidas tornaram-se mais confiáveis. Nesse momento contamos ainda com observações atentas e participantes, incluindo perguntas e conversas mais estruturadas e direcionadas. Conforme as regras da própria comunidade, assuntos específicos foram direcionados às pessoas responsáveis por essas informações. Ou seja, quando a intenção era levantar informações sobre algum tipo de artesanato, procurávamos o artesão correspondente, quando o assunto era a pesca, ou o cultivo de ostra, procurávamos os homens responsáveis, quando era sobre as histórias das trilhas, procurávamos conversar com os mais velhos, e assim por diante.

$\mathrm{Na}$ terceira e última etapa utilizamos a metodologia da história oral para coletar testemunhos em entrevistas voltadas exclusivamente para os moradores mais velhos do Mandira: Seu Floriano Mandira, Seu Arnaldo Mandira, Dona Saturnina Mandira de Oliveira, Seu Rubens de Oliveira e duas lideranças: Francisco Coutinho (conhecido como Chico Mandira) e sua esposa Irene Mandira. As entrevistas ocorreram nas casas dos entrevistados e foram estruturadas com perguntas livres, guiadas por temas, como: moradia, trabalho, pesca, roça, parentesco, lugares, histórias, comemorações, religiosidades, lembranças. O objetivo foi proporcionar uma conversa casual, que possibilitasse aflorar na memória seletiva do entrevistado as histórias significantes de sua vida e de seus antepassados.

Assim, a amostra de entrevistados não foi aleatória, visto que se prescindiu de aspectos minimamente relevantes para a representatividade e significância da amostra. O que se buscou, ao invés de grande quantidade de entrevistas, foi a qualidade das informações, conciliadas com as diferentes origens das fontes. Como procedimento padrão desse tipo de pesquisa, as entrevistas foram gravadas em câmara filmadora digital portátil. Todas as gravações foram transcritas na integra, em forma de documento, sendo apresentadas no anexo. Junto também se encontra os respectivos “Termos de Cessão Gratuita do Uso da Imagem e Depoimento", devidamente assinados. 
Deste modo, a história oral se alinha com a proposta da Arqueologia do Presente, de modo que "a evidência oral transforma os 'objetos' de estudos em sujeitos". (THOMPSON, 1992:137). As narrativas e histórias orais são importantes fontes de conhecimento para analisar as conseqüências materiais e os sistemas simbólicos que são subjacentes ao modo como as pessoas usaram, ocuparam e transformaram seu território. Por isso, os relatos orais proporcionaram dados tanto ao trabalho de living archaeology, explorando os lugares significativos e marcos simbólicos no território dos Mandira, quanto no trabalho de pesquisa nos documentos históricos.

Os trabalhos de levantamento e análise dos documentos históricos ocorreram em quatro instituições distintas: primeiro foi feito o levantamento dos estudos sobre a comunidade Mandira existentes na Fundação Instituto de Terras do Estado de São Paulo (ITESP-SP), onde encontramos o Estudo Técnico-Científico, que reconhece os Mandira como comunidade remanescente de quilombo. Este material foi de extrema importância para orientar o início dos trabalhos, tendo em vista a necessidade imediata existente em relação à demarcação do território e o relacionamento estabelecido entre o órgão público e a comunidade.

A outra instituição a ser pesquisada foi o Arquivo Público do Estado de São Paulo. Algumas etapas de pesquisa foram realizadas nos seus arquivos, no intuito de levantar o maior número de documentos referentes à comunidade e a fazenda Mandira ao longo do tempo. Infelizmente, devido a reforma da infra-estrutura do prédio, muitos serviços da instituição não estão funcionando temporariamente, entre eles a transcrição dos documentos que foram levantados. As pesquisas ocorreram basicamente em três tipos de documentação: O Livro dos Registros de Terra da Província de São Paulo; o Maço de Populações de Cananéia; e os Ofícios Diversos de Cananéia. As informações contribuíram muito para esclarecer alguns fatos históricos característicos da história dos Mandira. Essas informações foram compartilhadas com os próprios moradores do quilombo, gerando imenso interesse e novas curiosidades.

Houve ainda as pesquisas no Oficial de Registro de Imóveis e Títulos e Documentos da sede Comarca de Cananéia e de Jacupiranga. As pesquisas em ambas as instituições foram facilitadas, pois os documentos relativos ao registro das terras do sítio Mandira já estavam organizados nos sistemas de arquivos digitalizados. Na matrícula do terreno consta todo o histórico das ações sobre o mesmo e se revela documento testemunho da história oral dos Mandira. 
Outros documentos importantes para a reconstituição histórica dos Mandira seriam os registros de batismos e falecimentos que possivelmente se encontram nos arquivos da igreja, na Diocese de Registro. Entretanto, a diocese não possui uma infraestrutura adequada para o trabalho de arquivo e pesquisa desses documentos históricos. Em contato com a irmã Odete, responsável por esse serviço, fomos informados da impossibilidade de ter acesso a eles nesse momento.

Deste modo, na medida do permitido, realizamos uma verdadeira escavação sobre os documentos oficiais que envolvem direta ou indiretamente a história dos Mandira e de seu território. Procuramos, assim, levantar documentos que auxiliaram nas investigações etnoarqueológicas, a medida em que permitiram exercer um olhar crítico sobre as informações coletadas e inter-relações com as outras fontes de pesquisa. Com isso, logramos no intuito de que esses documentos forneceram luzes para novos questionamentos e informações que foram investigadas no território Mandira.

\subsection{Comunidade, negociação e aplicação metodológica.}

Nosso trabalho tem o cuidado de não assumir 'comunidade' e 'patrimônio' como termos confortáveis e ontologicamente fechados. Adotar esses termos seria reproduzir uma imagem atemporal e primitiva desses grupos que exigem o reconhecimento de sua alteridade. Antes disso, essas comunidades se apresentam como um agregado heterogêneo e alternativo de pessoas, com interesses diversos e disputas internas.

Também é importante salientar que um indivíduo pode pertencer a mais de uma comunidade ao mesmo tempo. Da mesma forma (como vamos ver), a comunidade como um todo pode ter mais de uma auto-denominação, tendo em vista as narrativas históricas e as relações cotidianas. Além disso, os próprios membros desses grupos, conscientes de sua condição marginalizada e do jogo político institucional, criam e utilizam essa imagem nostálgica da comunidade para estabelecer alianças com os especialistas que podem garantir seus direitos e assistências básicas.

Um dos argumentos centrais desse trabalho é discutir o fato do patrimônio ser um processo pelo qual grupos de comunidades estão envolvidos, devendo ser um processo aberto e acessível às diferenças, no sentido mais rico do termo. Essa orientação das diferenças suscita situações de conflitos sobre as definições e entendimentos de uma 
mesma coisa, solicitando trocas úteis e gratificantes de duas formas de ideias, experiências e interpretações sobre o patrimônio (SMITH \& WATERTON, 2011:15).

A partir deste posicionamento teórico, concordamos com a ideia de que a comunidade deve ser a preocupação central para toda a prática arqueológica e patrimonial. Por conta disso, o presente trabalho não se retém sobre as relações particulares entre os membros do Mandira. Apesar de algumas situações históricas, casos e relatos transparecerem essas relações, as discussões do trabalho giram em torno do foco da pesquisa que busca o processo pelo qual os Mandira se constroem enquanto comunidade quilombola. O modo como eles constroem os discursos pelos quais reivindicam sua alteridade, principalmente as responsáveis pelos seus interesses agrários e patrimoniais.

Muitos dos conflitos e tensões existentes entre comunidades e os profissionais do patrimônio (sejam pesquisadores ou legisladores) giram em torno das posições diferenciadas na participação significativa que cada grupo tem sobre a administração do processo patrimonial. Isso faz com que a inter-relação com a comunidade esteja além da programação do pesquisador ou do trabalho de campo. Essa relação acontece a todo o momento e envolve diferentes interesses e agentes. Quando se almeja realizar um trabalho multivocal com pretensões descolonizadoras, o modo como o cientista se posiciona nesse jogo de interesses estabelecendo relações e marcando posições, deve ser muito bem cuidado desde antes do começo dos estudos.

Por isso, já durante a fase de elaboração da pesquisa foram realizadas visitas a campo para conversar sobre a proposta do trabalho e adaptar o projeto às suas exigências e interesses. Nesse período participamos de reuniões da Associação Quilombola dos Mandira e do Conselho da Reserva Extrativista, no intuito de conhecer os membros e deixar claro o interesse e relação de poder envolvida. Por ser uma área de preservação ambiental federal, a reunião do Conselho é presidida pelo funcionário do Instituto Chico Mendes, do IBAMA, Valtency Negrão da Silva. Além dele, o conselho é formado por representantes do quilombo, dois representantes da Fundação Florestal (um da sede de Cananéia e outro da capital) e por representantes de organizações civis interessadas no assunto, como, por exemplo, a EAACONE - Equipe de Assistência e Assessoria das Comunidades Negras do Vale do Ribeira.

Nas duas reuniões, realizamos uma explanação sobre Arqueologia e o trabalho do arqueólogo, utilizando os materiais arqueológicos do Kit de Educação Patrimonial do Setor de Difusão Cultural do MAE. A proposta não era propriamente fazer um 
trabalho de educação patrimonial, mas usar as peças arqueológicas do kit como material de apoio interativo para despertar uma discussão sobre as possibilidades de pesquisa e uso do conhecimento arqueológico junto a comunidade. Desenvolver o projeto dentro dos interesses concreto da comunidade foi o primeiro desafio apresentado à pesquisa.

Enquanto pesquisador, então, conhecemos as pessoas, apresentamos nossa

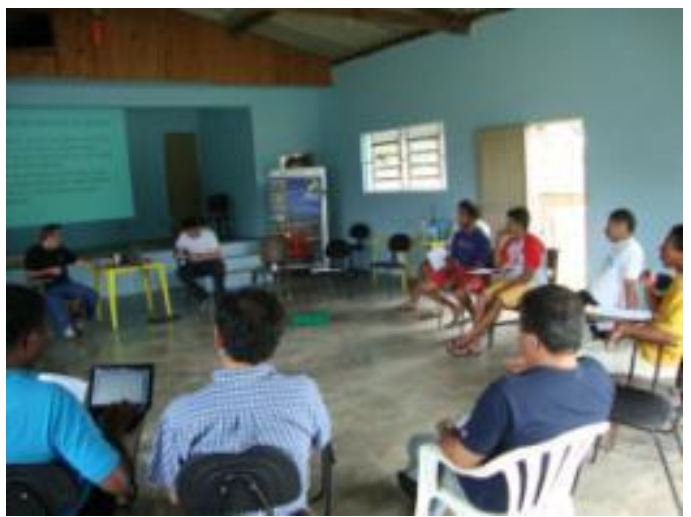

Figura 1: Reunião da RESEX Mandira, quando foi apresentado o Kit de Educação Patrimonial do MAE/USP aos presentes. biografia e proposta de pesquisa, para depois dar inicio a coleta e registro sistemático dos dados. Procuramos aplicar métodos de campo para abordar os moradores e conhecer as histórias à medida que participávamos das atividades pertinentes e das conversas informais e direcionadas: informações eram solicitadas, dúvidas retiradas, indicações coletadas, na tentativa de tornar nossa atuação e penetração no habitus da comunidade mais abrangente e menos agressiva.

Com isso, objetivamos documentar: 1) os processos de produção e uso de sua cultura material, incluindo a referência espacial; 2) o modo como a população quilombola usa o espaço territorial e doméstico em que vive, configurando as áreas de atividade; 3) a identificação e registro das estruturas e vestígios arqueológicos existentes em seu território; 4) as interpretações dos quilombolas sobre essas estruturas e vestígios arqueológicos; 5) o modo como esta população utiliza e se relaciona com os diferentes ambientes em que vivem, configurando uma paisagem cultural, composta de lugares significativos.

A partir da observação participante orientada arqueologicamente (living archaeology) e do levantamento das tradições e histórias orais, foram obtidas as informações possíveis sobre todos os elementos envolvendo essas práticas relacionadas. Desta forma, as prospecções arqueológicas não interventivas foram realizadas de forma assistemática, à medida que os lugares prospectados foram as áreas de atividades diárias e exponenciais dos moradores do Mandira e alguns lugares prospectados em momentos específicos levando em conta algumas informações levantadas nos relatos e histórias orais. 
As etapas de campo etnoarqueológico foram realizadas em etapas de campo de distintas durações: um período de mais de 30 dias seguidos, quatro etapas de campo de 15 dias e inúmeras visitas de uma semana a dois dias no quilombo, conciliando os diferentes períodos do ano. Seguindo a normalidade da comunidade, durante as estadas no Mandira, fomos hospedados sempre na casa de seu Chico e Dona Irene. Exceto os pesquisadores que chegam em grupos - por isso são instalados no galpão com colchonetes, mas fazem as refeições na casa de Dona Irene - a regra é o Seu Chico e Dona Irene receberem e hospedarem as pessoas de fora da comunidade que não são parentes.

Como não poderia deixar de ser, nossos informantes transitaram entre Seu Chico, Dona Irene, seus filhos Luis, Nei, Inácio e Agnaldo e uma de suas noras, a Thais $^{6}$, além de outros mandirenses como Bill, Evaristo, Zacarias, Zé Abraão, Dona Creusa, Jango e o falecido Seu Henrique Bernardo Coutinho, todos com algum grau de parentesco, e Seu Leonardo, que mora ao lado da escola e trabalha como caseiro do proprietário das terras dos Mandira. Para acompanhar as atividades diárias e as ações de prospecções programadas tivemos a principal companhia do Seu Chico ou de seu filho Luis. Mas também contamos inúmeras vezes com a presença de Bill e Inácio e em ocasiões pontuais com Dona Creusa, Seu Jango e Nei.

A presença de Luis, Bill e Inácio como principais acompanhantes nas prospecções realizadas pelo território seguiu critérios sociais quanto a categoria de gênero e idade. Alem disso, procuramos o convívio mais próximo com outras pessoas da comunidade que pudessem variar o gênero e idade, entre estes devemos citar: Vardo, Nilso, Juca, Vui, Cassiane, Jose, os meninos Rodrigo, Bruno, Romário, Jean e Chapolin e as crianças Lais, Ruele, Gabriela, Otávio e Henrique.

Esse convívio possibilitou o acesso às diferentes paisagens do território podendo realizar vistorias assistemáticas, oportunísticas, orientadas pelo próprio modo de ocupação do espaço territorial dos moradores. Além disso, rotas de reconhecimento foram realizadas em momentos específicos, contando com as informações orais da população local, para registro e mapeamento dos sítios e estruturas arqueológicas existentes fora da área de acesso cotidiano da comunidade.

\footnotetext{
${ }^{6}$ Durante minhas pesquisas no Mandira, o ISA (Instituto Socioambiental) realizou o levantamento dos bens patrimoniais de natureza imaterial das comunidades quilombolas do Vale do Ribeira. Nesta ocasião a Thais foi a principal interlocutora entre os Mandira e os pesquisadores do instituto, por isso tivemos algumas conversas sobre os bens patrimoniais da comunidade.
} 
As estruturas arqueológicas encontradas foram registradas com fotos e georreferenciamento (GPs - posições georreferenciadas), descritas e identificadas objetivando principalmente aferir sobre a forma, a extensão, a relação com o ambiente do entorno e o tipo do sítio em superfície, sem a intervenção na estrutura do mesmo (MORAES, 2006). Os locais que se configuraram como sítio arqueológico e não possuíam registro oficial foram devidamente catalogadas no Cadastro Nacional de Sítios Arqueológicos (CNSA), mantido pelo Instituto do Patrimônio Histórico e Artístico Nacional (IPHAN).

Todas as etapas foram georreferenciadas e a partir da comparação com outros mapas do território Mandira, produzidos pelo ITESP e pelo ISA, foram confeccionados três mapas temáticos do Território Mandira, dois históricos e um atual, um mapa da visão panorâmica do recôncavo de Cananéia e outro mapa geológico da região estuarino-lagunar. $\mathrm{Na}$ presente pesquisa os mapas temáticos são apresentados como instrumento comparativo do processo de ocupação do espaço e possíveis padrões de assentamento, quanto aos sistemas simbólicos que lhes são subjacentes e possibilitam a compreensão da inserção dos sítios na paisagem.

Deste modo as informações obtidas em campo pelas prospecções, observações, mapeamentos, conversas e entrevistas foram depuradas em laboratório. Essa etapa póscampo consistiu no detalhado processo de examinar e sistematizar as anotações e fotos coletadas, sendo organizadas segundo o critério de classificação determinado pelo recorte do projeto de pesquisa. Desta forma, foi embutido na própria trajetória de transformar as expressões coletadas em campo em expressões próprias do discurso da pesquisa acadêmica, as abordagens de diferentes crivos avaliativos (MACEDO, 2006).

Por fim, este método de pesquisa é continuo na medida em que se retorna ao campo para submeter às interpretações e sínteses aos membros da comunidade quilombola dos Mandira. Como todo processo de campo, este momento também se apresenta como um momento de negociação. Procuramos adotar aqui a metodologia empregada por Jackson \& Smith (2007), já exposta anteriormente, cuja prática de campo possibilitou desenvolver um parâmetro de consulta com as pessoas com quem trabalhavam na tentativa de adotar métodos não colonizadores e mais colaborativos ao estudo etnoarqueológico. Assim como a experiência no território aborígene, australiano, também no quilombo Mandira essa prática foi um dos fatores condicionantes na 
constante (re)avaliação crítica sobre o recorte do conteúdo pesquisado e (re)definição dos objetivos do projeto de pesquisa. 


\section{A HISTÓRIA QUILOMBOLA MANDIRA.}

Feito os esclarecimentos da base teórica e metodológica a ser percorrida, com alguns pontos dos debates históricos, antropológicos e arqueológicos sobre a noção de quilombo, pretendemos contribuir com as pesquisas em território quilombola e sobre arqueologia da resistência escrava através dos apontamentos etnoarqueológicos realizados em uma comunidade quilombola historicamente dedicada à resistência: $\mathrm{o}$ Mandira.

\subsection{Posição geográfica e características ambientais da Comunidade.}

\subsubsection{Vale do Ribeira.}

A comunidade Quilombola dos Mandira está localizada na parte continental do município de Cananéia, no extremo sul do litoral paulista, no Vale do Ribeira, mais especificamente, na região denominada Baixada do Ribeira, ou região EstuarinaLagunar de Iguape-Cananéia.

Com mais de 23 mil quilômetos quadrados, o Vale do Ribeira é a maior área contínua de Mata Atlântica do mundo, sendo 1.119.133 hectares no Estado do Paraná e 1.711.533 hectares no Estado de São Paulo (MAGALHÃES, 1997). Composto pela bacia hidrográfica do Rio Ribeira de Iguape e pelo complexo Estuarino Lagunar de Iguape, Cananéia e Paranagua, o Vale do Ribeira possui características de excepcional atenção aos estudos de deslocamento e assentamento humano. Entre outros fatores, pela peculiar característica do Ribeira de Iguape ser o único rio do Estado de São Paulo que atravessa a Serra do Mar e desemboca no Oceano Atlâncico, o Vale constitui-se como corredor de ligação entre planalto e litoral.

Segundo Aziz Ab’Saber (2006), a história geológica regional do Baixo Ribeira comporta um esquema brutal de soerguimento e dobramentos, aplicado à um conjunto litológico de rochas ígneas e metamórficas pouco desiguais. Portanto, essa faixa de dobramentos está incluída na compartimentação geotectônica da Faixa Ribeira, mais precisamente na Faixa de Dobramento Apiaí, a qual é caracterizada pela presença de rochas metamórficas, com idades variando desde o Arqueano até o Neoproterozóico. 
Essa região sofreu sucessivos eventos deformacionais com metamorfismo atingindo as fácies anfibolito e granulito. No Neopaleozóico, rochas graníticas pós-tectônicas intrudem as rochas metamórficas do Dobramento Apiaí.

Nesse contexto de formação das escarpas da Serra do Mar, associado aos processos erosivos e a topografia favorável à deposição de sedimentos, geraram extensos depósitos quaternários na região. Esses depósitos são caracterizados segundo a descrição das unidades litoestratigráficas do Mapa Geológico (IPT, 1981) como depósitos areno-argilosos de origem eluvio ou coluvionar, próximo às encostas, denominado como Sedimentos Continentais Indiferenciados (Qi) e os sedimentos Marinhos Mistos (Qm), que são depósitos marinhos, retrabalhados, de deposição fluviomarinho-lacustre e depósitos de mangue. Nas porções mais distantes, ocorrem as areias marinhas finas inconsolidadas da Formação Cananéia (Qc). Esses depósitos quaternários caracterizam a atual planície costeira de Cananéia e Iguape, no Baixo Vale, (conforme representado pelo Mapa Geológico no Anexo 1).

A cerca de dois milhões de anos atrás, a região já apresentava as características gerais que propiciaram o encaixamento do rio Ribeira e seus afluentes até o nível dos baixos terraços cascalhentos quaternário, pertencente a Formação Pariquera-Açu, a qual delimita a faixa de transição entre o atual médio Vale do Ribeira e a planície costeira de Cananéia e Iguape, ou Baixo Vale (AB'SABER, 2006:92).

Devido às constantes mudanças climáticas iniciadas no fim do Pleistoceno e durante todo o Holoceno, as intensas variações do nível do mar foram a principal causa do acúmulo de sedimentos sobre a planície costeira de Cananéia e Iguape. Sabe-se que há cerca de 120 mil anos atrás, o nível do mar estava aproximadamente a 8 metros acima do atual, no ápice da transgressão denominada "Transgressão Cananéia". A paisagem regional era formada por uma grande paleobaia que cobria toda a planície costeira e banhava os pés do terraço cascalheiro da Formação Pariquera-Açu.

Nos períodos sucessores o nível do mar desceu formando uma rede hidrográfica sobre seus depósitos sedimentares, atingindo em 17.500 anos AP., um nível marinho 100 metros abaixo do atual. Após este máximo regressivo, o nível do mar subiu exponencialmente. Quando o mar em ascensão atingiu o presente nível, entre 7 mil e 6.500 anos AP. (Transgressão Santos), as zonas baixas resultantes da erosão dos antigos terraços foram invadidos pelo mar, formando assim um sistema lagunar mais extenso. A ascensão do nível marinho atingiu 4 metros de altura aproximadamente à 5.150 anos AP. De lá até os dias de hoje, o nível do mar voltou a descer mais ou menos 
regularmente, com duas importantes flutuações negativas entre 4.100 e 3.600 ano AP e 3 mil e 2.500 anos AP, até atingir o nível atual (MARTIN et al., 1985).

\subsubsection{Aspectos físicos do município de Cananéia.}

Diferente da parte alta do Ribeira, na planície sedimentar da baixada o rio serpenteia lentamente os inúmeros meandros e é banhado por seus afluentes, até desaguar ao norte de Cananéia, no município vizinho, Iguape, de encontro ao extremo norte da Ilha Comprida, mais especificamente na Barra de Icapara. Toda a região do baixo vale pode ser caracterizada sob o aspecto biofísico como representante típico do complexo estuarino-lagunar, marcado pela presença de montanhas e escarpas da Serra do Mar, pequenos morros e morrotes distantes um dos outros, que mais se destacam na planície e nas ilhas perto da costa, formando distintos ambientes como ilhas, lagunas e canais. A flora da região é desenhada por mangues, restinga, várzea, vegetação hidrófila e floresta tropical, compondo uma biodiversidade rica, características típicas da Mata Atlântica.

Pasquale Petrone (1966) diferencia a Baixada do Vale do restante da fachada atlântica, por possuir uma extensa planície litorânea, que se aprofunda aproximadamente 80 quilômetros para o interior, no extremo norte e 30 quilômetros entre a costa e a Serra do Mar, no extremo sul, com largura de aproximadamente 90 quilômetros. Nesta porção de planícies retilíneas de maiores extensões apresentam trechos de terras firmes e elevadas, discretamente onduladas, com baixa densidade de drenagem. Quanto mais para o interior, a paisagem vai gradualmente sendo entremeada com traços de serra, até as escarpas da serra de Paranapiacaba a noroeste e norte, e a serra do Mar a nordeste e oeste, que a emolduram em um grande semi-círculo, formador da paleobaía. A Área abrange as três Zonas da Província Costeira: a Serrania Costeira, estando representada por quatro Subzonas, a Baixada Litorânea e a Morraria Costeira, além do Planalto do Alto Turvo, no Planalto Atlântico, conforme apresentado na tabela 1 adaptada do mapa geomorfológico do IPT (1981). 


\begin{tabular}{|c|c|c|}
\hline PROVÍNCIA & ZONAS & SUBZONAS \\
\hline \multirow{4}{*}{ Costeira } & & 1a. Serra do Mar \\
& 1-Serrania Costeira & 1c. Serrania de Itatins \\
\cline { 2 - 3 } & & 1d. Serrania do Ribeira \\
\cline { 2 - 3 } & $2-$ Baixadas Litorâneas & 1e. Planaltos Interiores \\
\cline { 2 - 3 } & $3-$ Morraria Costeira & - \\
\hline $\begin{array}{c}\text { Planalto } \\
\text { Atlântico }\end{array}$ & $13-$ Planalto do Alto Turvo & - \\
\hline
\end{tabular}

Tabela 1: Divisão geomorfológica do Baixo Vale.

Nesse mosaico de terras recortado por águas, historicamente chamado Lagamar, encontra-se ao sul, a área munícipe de Cananéia. Esta área, denominada por Petroni (op. cit.) de Recôncavo de Cananéia, é formada pela ponta sul da Ilha Comprida à leste, pela Ilha de Cananéia estendida de nordeste ao centro, pela Ilha do Cardoso ao sul e pelo continente a norte, noroeste e oeste (ver "Mapa Panorâmico" no Anexo 1).

A abundância hidrográfica certamente está relacionada à uma pluviosidade elevada, de 1.500 a $2.000 \mathrm{~mm}$ anuais, com precipitações constantes durante o ano, sem uma estação de seca. Contudo, os traços do relevo regional e a proximidade da Serra do Mar funcionam como protetor dos ventos continentais e como tampão das massas de ar do Oceano, produzindo uma dinâmica atmosfera regional responsável por manter o clima quente e úmido.

A temperatura também permanece constante na maior parte do ano. Nos meses de inverno, quando chove menos, de junho a agosto, a massa de ar frio proveniente do pólo sul no ambiente úmido da região provoca queda brusca da temperatura, chegando a mínima de $10^{\circ} \mathrm{C}$. No verão, com chuvas em $50 \%$ dos dias a temperatura atinge $40^{\circ} \mathrm{C}$.

Associado à geologia, o complexo sistema hídrico desta região proporciona constantes processos de transformação da paisagem. Segundo Adams (2000), as águas da Mata Atlântica podem ser divididas em dois tipos: as claras e as escuras. Os rios de águas claras são alimentados pelas águas de chuva e originam-se nas escarpas da Serra do Mar. Como o substrato do Pré-Cambriano (da Serra do Mar) é muito antigo, com lixiviação avançada, há baixíssima adição de nutrientes à água da chuva. Portanto, a alimentação da fauna de insetos aquáticos é basicamente dos materiais em 
decomposição vindos da mata. Ao atingirem a planície costeira, forma-se uma rica fauna de peixe.

Já os rios de água preta, são lentos cursos d'água que drenam lentamente a planície aluvial da restinga. Com elevação média de 4 metros, estas planícies permitem a entrada da água do mar, dependendo das condições da maré e da época do ano. Nas épocas de chuva, principalmente, os nutrientes da decomposição incompleta da matéria orgânica proveniente dos ecossistemas de alto relevo são devolvidos pela água do mar ao ambiente costeiro da restinga, promovendo a cor escura dos rios (ADAMS, 2000:77).

A restinga é uma formação vegetal com substrato Pleistoceno-Holoceno, compondo ambientes entre a encosta das Serras e a linha costeira. As formações mais antigas estão situadas no interior e em altura de até 10 quilômetros do nível do mar e a elas estão associadas às ocupações humanas mais antigas da faixa litorânea do Baixo Vale do Ribeira. O terreno é sedimentar, formada por cordões litorâneos paralelos à linha costeira. A sedimentação constante e o assoreamento provocaram a fusão destes cordões de sedimentos marinhos predominantemente arenosos com base argiloarenosos, denominada Formação Cananéia (SUGUIO, 1973). Extremamente pobre em nutrientes, a topografia é praticamente plana, marcada por pequenas depressões onde o solo pode apresentar composição mais rica, com a deposição de turfas, que permite o aparecimento de uma vegetação de maior porte. As plantas epífitas são predominantes, como as bromélias, as orquídeas e as aráceas. Já a fauna é reduzida, geralmente composta por roedores introduzidos ou lagartos raros.

Outro ecossistema importante formado em ambientes de costa protegida e banhada pela maré são os manguezais. Formados da mistura de águas doce e salgada e a consequente riqueza de nutrientes fazem com que os manguezais sejam zonas de elevada produtividade biológica, uma vez que são encontrados representantes de todos os elos da cadeia alimentar. Esses ambientes são vistos como fixadores de energia por possuírem abundante diversidade de espécies de peixes, crustáceos, poliquetas e um grande número de bivalves, que buscam refúgios nas raízes das plantas. Por ser um ambiente intermitente entre os momentos encharcados e inundados pelas águas salobras, sua vegetação desenvolveu um grande sistema radicular, que escora vegetações arborescentes ou arbustivas.

Além da rica cobertura vegetal, a fauna do Lagamar também é extremamente diversificada. Composta principalmente pela fauna aquática, com diversas espécies de peixes, camarão, tartarugas, anfíbios e molusculos em geral, como ostras (Crassostrea 
brasiliana), além de mamíferos aquáticos, como os botos-cinzas (Sotalia guianensis). Entre outros animais da Mata Atlântica encontramos no Lagamar animais de médio e grande porte, como anta, macaco-prego, bugio, quati, tatu, gambá, tamanduá, raposa, veado e a onça-pintada. Existem também os repteis e em maior quantidade as aves, muito apreciadas tanto pelas populações locais como pelos visitantes.

\subsubsection{Localização geográfica dos Mandira.}

A Serra do Mandira está localizada entre a Serra do Boacica e a Serra do Porto do Meio. Esse conjunto de Serras é definido como um alto topográfico regional, pertencente a Faixa de Dobramentos Apiaí, caracterizada pela presença no seu embasamento de rochas ígneas e metamórficas. Portanto, fazem parte da área fonte dos sedimentos quaternários depositados tanto na base das encostas (sedimentos mais grosseiros), como na planície litorânea (areias marinhas finas).

A comunidade está situada na estreita faixa de terra entre a encosta da Serra do Mandira e a restinga interna que abriga os vários mangues que banham a área. O local onde se encontra o território quilombola Mandira e seu entorno é descrito por Aziz Ab'Saber da seguinte forma:

“A planicie lagunar de Cananéia-Iguape é o império das alternâncias costeiras entre restingas e lagunas, rigidamente orientadas de nordeste para sudoeste. Na região de Cananéia, após a Ilha Comprida, se sucede o Mar de Fora de Cananéia, a Ilha de Cananéia, o Mar de Dentro ou de Cubatão; e, por fim, a Restinga Interna, separada da retroterra cristalina por córregos e pelo embrião de lagunas do baixo Itapitangui." (AB'SABER, 2006:95-6, grifo onde sinaliza o local de moradia dos mandirenses).

Há cerca de $10 \mathrm{Km}$ do bairro Itapitangui, seguindo a estrada municipal Colônia Santa Maria - Mandira, que leva a comunidade do Ariri, já na divisa com o Paraná, na parte continental do município de Cananéia, encontra-se o Território Mandira, entre as UTM 23J 0800485/ 7232432, a leste e UTM 23J 795262/ 7231147, a oeste. Ocupando 
áreas da restinga interna até o mar de dentro, ao sul e a extensão do morro do Mandira, de retroterra cristalina, ao norte, a comunidade se localiza entre o rio Boacica e o rio Acaraú (ver "Mapa Panorâmico" no Anexo 1).

\subsection{Histórico de formação da comunidade quilombola Mandira.}

Contando com 21 famílias, segundo os dados levantados pelo Ponto de Cultura Caiçara de Cananéia $^{7}$, atualmente residem no Mandira cerca de 120 pessoas. Localizados entre a encosta da Serra do Mandira e os vários mangues que banham a área, os Mandira formam uma comunidade entendida como um conjunto de núcleos familiares interligados por laços de parentesco, que compartilham o mesmo ambiente historicamente explorado, conhecido e habitado. Assim como outras comunidades, existem pessoas com o sobrenome Mandira espalhados por outras regiões, tanto do Vale do Ribeira quanto do Estado de São Paulo, entretanto, por um processo histórico, a maioria dessas pessoas não cultivam laços estreitos com o território Mandira, por isso, como veremos, não são considerados quilombolas.

A comunidade do Mandira é reconhecida como remanescente de quilombo pelo "Relatório Técnico-Científico sobre os Remanescentes da Comunidade de Quilombo de Mandira/ Cananéia-SP”, elaborado pela antropóloga Maria Cecília Manzoli Turatti, em 2002, a pedido da Fundação Instituto de Terras do Estado de São Paulo "José Gomes da Silva" (ITESP) ${ }^{8}$.

Os primeiros registros históricos confirmam na região a presença de africanos trazidos como escravos, no final do século XVIII (CHIQUINHO, 2007:65). Segundo os estudos do Ponto de Cultura Caiçara existem indícios de que os negros que vinham sem sobrenome, procuraram o Salto do Ipiranguinha para se refugiar, um lugar que fica

\footnotetext{
${ }^{7}$ Ponto de Cultura é atualmente a principal ação de um programa do Ministério da Cultura chamado Cultura Viva, concebido como uma rede orgânica de gestão, agitação e criação cultural. O Ponto de Cultura não é uma criação de projetos, mas a potencialização de iniciativas culturais já existentes. $\mathrm{O}$ Ponto de Cultura Caiçara foi criado em Cananéia há cinco anos. Durante este tempo adequaram um espaço físico para a compra de equipamentos áudio visuais e realizam cursos, oficinas culturais e produção contínua de linguagens artísticas (músicas tradicionais, danças, vídeos, capoeira, livros, entre outras). Para mais informações sobre Ponto de Cultura ver o site: http://www.cultura.gov.br/culturaviva/ponto-de-cultura/

${ }^{8}$ A Fundação Instituto de Terras do Estado de São Paulo (ITESP) é o órgão estadual responsável por planejar e executar as políticas agrárias e fundiárias e pelo reconhecimento das Comunidades de Quilombos de São Paulo. É vinculado à Secretaria de Estado da Justiça e da Defesa da Cidadania.
} 
perto da Serra do Mandira, nas proximidades do bairro Santa Maria. Segundo Seu Chico Mandira, o início do quilombo remete ao século XIX, com a memorial figura de Francisco Mandira, fruto da relação amorosa de um senhor branco com sua escrava negra.

\subsubsection{A família Andrade em Cananéia.}

Francisco seria então filho de Antônio Florêncio de Andrade, homem branco, natural de Iguape, com uma de suas escravas, cujo nome não se sabe ao certo. Os primeiros registros de Antônio Florêncio de Andrade como morador da Comarca de Cananéia encontra-se no rolo 0039 do "Maço de População" do Arquivo do Estado, referente ao ano de $1811^{9}$. Neste registro, Antônio Florêncio de Andrade aparece com 33 anos, vivendo de lavoura, casado com Rita Francisca, de 42 anos, pai de dois filhos, José de 03 anos e João de 02 anos, e senhor de cinco escravos, dois adultos, uma jovem e duas crianças. Todavia, assim como todos os dados pesquisados, os registros escritos devem ser analisados com cautela, de forma investigativa, procurando contextualizar o modo como as informações foram formadas.

Como vimos, Cananéia é um distrito composto de parte continental e parte insular, com comunidades e sítios isolados do centro urbano, por terra ou mar. Esse era o caso da Fazenda dos Andrades, isolada na parte continental do município, por onde só se chegava pelo canal do Mar de Dentro. O "Maço Populacional” pretendia abranger os dados da totalidade dos habitantes da capitania e depois da Província de São Paulo. As informações eram coletadas seguindo importantes e modernas técnicas de recenseamento da época, implantadas pela Ordem Régia de 21 de outubro de $1797^{10}$. Entretanto, no final do século XVIII Cananéia passava por uma de suas piores crises econômicas em decorrência do edital de setembro de 1787, ordenado pelo capitãogeneral Bernardo José de Lorena, pelo qual todas as embarcações que zarpassem dos portos do litoral, ficavam obrigados a escalar em Santos. A ordem visava arrecadar

\footnotetext{
9 Arquivo Público do Estado de São Paulo, referente ao microfilme do "Maço de População" de Cananéia, ordem 0039, anos 1806 à 1829 (ver páginas correspondentes digitalizadas como imagem no Anexo 2).

${ }^{10}$ Os "Maços de População de São Paulo" formam uma extensa série documental de caráter censitário produzida entre 1765 e 1850 . A confecção dessas listas de caráter nominativo visava, inicialmente, coletar informações sobre a disponibilidade de homens aptos ao serviço militar. Somente em 1797, a Ordem Régia norteou novas orientações que buscavam uma política mercantilista mais dinâmica e preocupada em racionalizar a máquina administrativa colonial e em incrementar a população, a agricultura e o comércio do Império português.
} 
impostos, abastecer a capital e tirar Santos de seu isolamento econômico. Segundo Paulino de Almeida (1948), seu efeito foi o fim da liberdade comercial marítima entre os portos do litoral, principalmente para o Rio de Janeiro. As embarcações sumiram, os estaleiros foram fechados e a maioria da população de Cananéia mudou-se para Iguape e Paranaguá ou se embrenharam pelo interior em busca de ouro, cuja ocorrência já existia desde o fim do século XVI.

Essa situação só começou a mudar quando em 1808, com a chegada da família real, os portos foram novamente abertos e o comercio entre eles liberado. Aos poucos o porto de Cananéia volta a ser um importante centro comercial na exportação de mantimentos, como farinha, arroz, feijão, fumo, erva-mate e principalmente produtos da pesca. Ainda hoje, Cananéia é caracterizada por esse tempo. No centro da cidade predomina preservado o traço arquitetônico dos grandes casarões coloniais dessa época, edificadas com pedras e assentadas com argamassa constituída basicamente da moagem de conchas dos sambaquis e misturadas com óleo de baleia (ALMEIDA, 1961; DURAN, 2008; BAVA DE CAMARGO, 2009).

Entre os mantimentos exportados predominava a comercialização do arroz, que atingiu seu auge ainda na primeira metade do século XIX, quando a mão-de-obra escrava e as embarcações a vela eram essenciais para sua produção e escoamento. Segundo Bava de Camardo (2009:24) os engenhos de arroz na região de Cananéia eram exclusivamente movidos a energia hidráulica até a década de 1880. Depois desta data passaram a utilizar os engenhos mecânicos primeiro a vapor e depois a explosão, os quais poderiam centralizar o serviço de pilar arroz no núcleo urbano. Deste modo, até o fim do século XIX, os engenhos de arroz eram instalados longe dos núcleos urbanos, em locais propícios ao aproveitamento da força hidráulica para funcionar. Assim, a produção de arroz do recôncavo de Cananéia era encaminhada em sua maioria, aos engenhos rurais para serem processados. Só após serem beneficiadas, as sacas de arroz eram encaminhadas em grande quantidade aos entrepostos urbanos.

Esse particular sistema de circulação dos produtos foi favorecido pela característica geográfica de Cananéia. Em uma região sem estradas ou ferrovias, extremamente irrigada, com entraves de rios e canais interligando ambientes navegáveis em mares de dentro, o sistema de navegação interior favoreceu a descentralização comercial. Associado a isso, problemas com a conservação dos gêneros e a dificuldade dos pequenos produtores em estabelecer uma navegação de grande porte e regular, que justificassem os gastos dos trajetos mais longos até os centros urbanos (BAVA DE 
CAMARGO, op. cit:24-25), fez com que os engenhos de beneficiamento de arroz funcionassem como atravessadores nas comercializações dos produtos.

Assim, os engenhos eram alimentados por produtos de pequenos agricultores familiares, que utilizavam canoas ou as tropas de mulas para encaminhar as sacas de arroz onde seriam beneficiados. Provavelmente, outros gêneros de subsistência também eram comercializados nestes engenhos, que concentravam os produtos de diversas localidades. O engenho também era alimentado pela produção da fazenda onde estava situado, cuja mão-de-obra era inicialmente escrava (BAVA DE CAMAGO, op. cit:2527).

Os dados apontam que a fazenda dos Andrades no entorno do rio Mandira era uma dessas fazendas com um engenho de beneficiar arroz, que funcionava como entreposto dos produtos dos pequenos agricultores do entorno. Assim, do mesmo modo em que a técnica de recenseamento foi sendo apropriada pela administração pública de Cananéia, a Fazenda dos Andrades parece ter acompanhado a ascensão econômica da Comarca. Apesar da incoerência na relação de algumas idades com as datas de coleta dos dados e a falta de lógica nos anos de registro, constatamos pelos documentos que, depois de 1811, a próxima menção sobre Antônio Florêncio de Andrade data do ano de 1825, quando ele aparece com 40 anos e sua mulher com 45, vivendo de lavoura. A família já tem três filhos: José, 14, João, 13 e Celestina, 12 e dezesseis escravos: quatro homens, seis mulheres, cinco crianças e um bebe de seis meses (11 escravos a mais que o último registro, treze anos atrás). Entre a relação de nomes dos escravos aparece o substantivo Francisco, referente a uma criança de três anos de idade.

$\mathrm{Na}$ sequencia dos documentos ${ }^{11}$ temos em ordem o registro de 1831, onde mostra um dos escravos de Antônio Florêncio de Andrade, chamado Francisco, com sete anos e em 1848 o mesmo escravo com 24 anos. Já nesta época Antônio Florêncio com 64 anos e sua mulher com 78, vivem apenas com uma filha, Celestina com 37 anos, e vinte e oito escravos.

A partir de 1831 o filho João não aparece mais nos documentos e não se sabe do seu paradeiro. José Florêncio de Andrade, por sua vez, aparece registrado no $2^{\circ}$ Quarteirão da Villa de Cananéia no ano de 1842, o que indica sua mudança para o centro urbano do município, já que seu pai Antônio Florêncio permanece no $5^{\circ}$

\footnotetext{
${ }^{11}$ Arquivo Público do Estado de São Paulo, referente ao microfilme do "Maço de População" de Cananéia, ordem 17.01.0038, anos 1830 à 1856 (ver páginas correspondentes digitalizadas como imagem no Anexo 2).
} 
Quarteirão de Itapitangui. Essa informação é confirmada pelo material referente aos "Ofícios Diversos" de Cananéia ${ }^{12}$, onde encontramos o nome de José Florêncio de Andrade como membro da Câmara Municipal por diversas legislaturas assinando cartas e decretos.

Não existem mais registros de Antônio Florêncio de Andrade depois de 1848. Sabe-se que o recenseamento dos Maços Populacional encerrou em 1850, quando inicia-se o registro de Terras. Neste livro, pesquisado também no Arquivo Público do Estado, indica que Antônio Florêncio de Andrade faleceu antes de 1854, já que as terras do sítio Mandira aparecem nessa data divididas e registradas em nome de Rita Francisca de Jesus, Celestina Benécia de Andrade e José Florêncio de Andrade ${ }^{13}$.

Com o falecimento de Antônio Florêncio de Andrade, o sítio Mandira foi então dividido em quatro partes: a Rita Francisca coube dois quartos referentes às partes localizadas rio acima; à José Florêncio um quarto referente às terras da Barra do Mandira e uma porção de terras rio acima; e para Celestina Benécia de Andrade "uma quarta parte do sítio Mandira, sendo por herança de seu finado pai Antônio Florêncio de Andrade, cujas terras dividem para rio a cima com terras de sua mãe e para rio a baixo com terras de seu irmão José Florêncio de Andrade" (Registro de Terras da Província, distrito de Cananéia, cód. 17.04.039, no. 107, pág. 25 - ver Anexo 2).

Não podemos afirmar quais os limites exatos de cada parte do sítio, pois as delimitações eram feitas com menção ao nome do proprietário vizinho, entretanto, pelo que tudo indica, Rita Francisca era uma mulher de idade avançada e não tardou muito a falecer. Celestina aparece nos registro como mulher solteira e sem filhos. Com a morte do pai, ela deve ter ficado junto à mãe, morando com o irmão ou perto do mesmo, como era de costume naquela época.

Não se sabe ao certo como foi a divisão das terras do sítio Mandira após a morte de Rita Francisca. Sabe-se, através de um texto de doação guardado pelos moradores mais velhos da comunidade do Mandira e transcrito pelo falecido padre João Trinta, da paróquia do município de Cananéia, que, no ano de 1868, Celestina Benícia de Andrade, filha legítima de Florêncio de Andrade, doou uma sorte de terras denominada

\footnotetext{
${ }^{12}$ Arquivo do Estado de São Paulo, referente aos "Ofícios Diversos" de Cananéia (Caixa 00862).

${ }^{13}$ Registro de Terras da Província, município de Cananéia, ano 1854, vol. 120, código 17.04.039, página 24 verso (no. 106), pág. 25 (no. 107) e pág. 38 (no. 167) (ver páginas digitalizadas como imagem no Anexo 2). José Florêncio de Andrade aparece também entre os 50 primeiros nomes do mesmo Registro de Terras da Província, município de Cananéia (código 17.04.039, registros número 46, 47, 48 e 49), como possuidor de terras na costa do rio Taquari e no rio Piranguinha de cima por compra e outras terras no lugar denominado Morrete, no rio Das Minas, adquirido por doação de seu pai.
} 
"Sítio Mandira" à seu meio irmão, Francisco Vicente ${ }^{14}$. Nessa data, podemos aferir por base nos registros do "Maço Populacional", que Francisco provavelmente tinha 44 anos de idade e sua meia-irmã 57 anos (TURATTI, 2002:19).

Celestina era uma mulher solteira, sem herdeiros, e seu irmão, José Florêncio, dono de muitas terras. Os documentos mostram que Florêncio investiu na carreira política e, por isso, estava mais interessado na vida social da cidade do que no trabalho do campo. Nesta época, meados dos anos 1870, o tráfico de escravo já estava proibido há quase vinte anos. A pressão para por fim a escravidão era muito forte no país, principalmente na Província Paulista, onde se concentravam os principais líderes dos movimentos abolicionistas e políticos que tendiam a Proclamação da República (SCHMIDT, 1941; SANTOS, 1942; MORSE, 1970; PEREIRA, 1979). Provavelmente, esses fatos foram decisivos para José Florêncio e Celestina de Andrade doarem o sítio Mandira, como ato de caridade ao seu meio irmão, ao mesmo tempo em que se viam livres das despesas com as terras e os escravos.

\subsubsection{A primeira divisão do território Mandira.}

Segundo as histórias orais levantadas em campo, quando Francisco Vicente herdou as terras, ele já estava casado com a escrava de nome Teresa e possuía filhos. Apesar do recenseamento do maço populacional de 1831 não apresentar nenhuma referência ao nome Tereza, o registro de 1847 mostra esse nome entre a lista de escravas de Antônio Florêncio de Andrade, com 20 anos de idade. Não existem narrativas históricas sobre Francisco Vicente após a doação das terras, ou sequer conseguimos levantar documentos escritos do Mandira relativo a esse período. Dizem que ele teve muitos filhos e que permaneceu vivendo com os outros ex-escravos na fazenda, estabelecendo relações com os vizinhos e comerciantes locais da mesma forma, mas livre para obter seus próprios recursos da terra e estabelecer seus próprios relacionamentos.

Antes de morrer, Francisco dividiu as terras do sítio entre dois filhos: Antônio Vicente Mandira e João Vicente Mandira. Ao primeiro coube a porção de terras a cima do Salto do Mandira, já o segundo estabeleceu-se na área situada ao sul do mesmo

\footnotetext{
${ }^{14}$ Uma cópia deste texto de doação encontra-se como anexo do "Relatório Técnico-Científico Sobre os Remanescentes da Comunidade de Quilombo de Mandira/Cananéia-SP", escrito por Maria Cecília Manzoli Turatti, a serviço do ITESP, fevereiro de 2002.
} 
ponto. Segundo Dona Saturnina neta de João Vicente Mandira e, atualmente, uma das moradoras mais antigas da comunidade - os dois herdeiros de Francisco brigavam muito sobre o local exato do divisor das terras. Os dois queriam se apropriar do salto do Mandira.

Relatam que Antônio morava ao

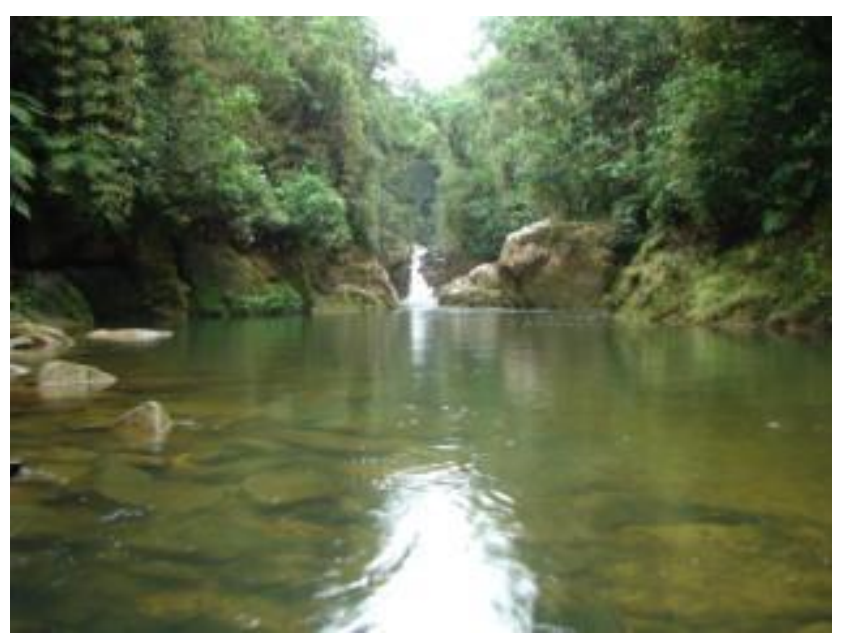

Figura 2: Salto do Mandira. lado do salto, e estabelecia como marco divisor das terras um Arapaçu que emitia um forte ruído quando seu tronco era incidido com algum objeto rígido. Mas João brigava para ele morar acima do salto, querendo estabelecer a cachoeira como marco divisor.

Seu Rubens de Oliveira, marido de Dona Saturnina e herdeiro do Sítio do Porto do Meio, vizinho ao Mandira ${ }^{15}$, conta que João Vicente Mandira era uma pessoa com gênio forte. Segundo ele, João não deixava Antônio parar a canoa no porto de baixo. Antônio tinha então que carregar a canoa alguns quilômetros rio a cima, até perto do salto.

Seu Chico apresenta a versão inversa da história: em seu relato, João aparece como um homem pacífico e Antônio é apresentado como uma pessoa ruim e egoísta:

\begin{abstract}
"Pelo o que eu sei (...) Antônio não gostava que ninguém pegasse nada dele, ele escondia sua canoa no meio do mato pra ninguém pegar (...) João fazia roça no salto e quando o milho estava bom de quebrar, Antônio quebrava tudo e carregava. Com a canoa, ele quebrava a canoa de João ao meio e levava metade em borá, quando João ia varar a canoa estava só metade. Foi ai que eles dividiram. Pra evitar confusão, Antônio ficava do morro da pedra pra lá e João ficava do morro da pedra pra cá. "16
\end{abstract}

\footnotetext{
${ }^{15}$ Seu Rubens é filho do falecido Antônio Leandro de Oliveira e neto de Beijamin Constante de Oliveira, antigos proprietários do sítio Porto do Meio, vizinho do Mandira. Ele é casado com Dona Saturnina há mais de cinquenta anos. Ele vivenciou o período em que seus pais e avôs ainda vivos conviviam amigavelmente com os moradores dos Mandira. Ainda guarda na memória as histórias que seu pai e avô contavam sobre a relação que existia entre os moradores dos dois sítios.

${ }^{16}$ Nota-se aqui que Seu Chico é bisneto de João Mandira e as histórias contadas à ele foram dos filhos e netos do João Mandira.
} 
Independente das duas versões da história, a figura de João Vicente Mandira é lembrada por sua habilidade como vidente. Dizem que ele podia prever quando alguma coisa iria acontecer dias antes do fato consumado. Com esse dom, João brigou durante muito tempo com o Coronel Cabral de Cananéia, quem dizia ser proprietário da porção de terras que se estendia desde o bairro de Itapitangui, em Cananéia até Guaraqueçaba, na baia de Paranagua, no estado do Paraná. Contam que ele previa as emboscadas armadas pelos capangas do Coronel, quem queria ver João Mandira morto para desestruturar a comunidade e se apossar das terras. Por causa disso João teria registrado as terras em seu nome no ano de 1912 (ver documento do registro de imóveis Comarca de Cananéia reproduzido com imagem no Anexo 2).

Já Antônio Mandira é retratado entre os Mandira por sua força descomunal. Dizem que para não pegarem seu remo, ele fez um com mais de dois metros de cabo. Esse remo pesava tanto que não havia pessoa capaz de tirá-lo do lodo do mangue. Sua força era tanta que na época da seca, ele carregava a canoa nas costas do Porto-de-fora até a região chamada de "as Areias", onde ele morava antes da divisão das terras. Outros já falam que para evitar as brigas com o irmão, ele levava a canoa nas costas rio à cima, até o salto. Lembram-se dele também como um ótimo caçador. Dizem que ele conseguia tanta caça que sobrava carne pra vender na cidade.

\subsubsection{Atividades econômicas: a caça e a roça.}

Entre os Mandira a caça nunca foi uma atividade para a obtenção de lucro. As carnes de caça eram para consumo próprio e a partilha com familiares e amigos. "Nunca ninguém vendia (...) Se matava uma caça também era dividida, cada um comia um pedaço." Seu Chico conta que antigamente, quando a caça não era proibida, os homens andavam com a arma nas costas, sempre a espreita de uma caça. “(...) e tinha caça a vontade... Tinha caça, tinha passsarinho. Por que o pessoal respeitava a época de criação do bicho." Para Seu Chico, a proibição da caça negligencia o sentido ancestral de caçar. Colocada na clandestinidade, a atividade ocorre sem conhecimento e envolvimento com o ambiente e seus elementos. A caça passou a ser feita as escondidas durante todo o ano, sem distinção de animal ou lugar. Essa mudança de hábito, causado pelo desconhecimento, faz com que a ação do homem seja um fator de desequilíbrio entre as espécies, sendo sentida pela diminuição da quantidade de animais. 
Antigamente, quando a caça não era proibida, as crianças cresciam brincando de capturar passarinho. Os meninos faziam armadilhas e desde os oito, nove anos já usavam o estilingue e o bodoque. Assim, a atividade de caça era desenvolvida desde muito cedo, sempre presente na vida das pessoas. Quando nascia um filho homem, era costume o avô ou o pai dar um tiro de espingarda para o mato. Diziam que isso fazia o menino crescer como um bom caçador.

O bom caçador é retratado como a pessoa que tem uma boa mira. Mas para caçar não basta ter uma boa vista, tem que saber antes no que está atirando, pois cada animal tem um costume próprio e se desloca de um jeito no meio do mato. Contam que entre os Mandira existia um homem com problema de vista, mas não errava um passarinho, acertando todos na cabeça.

As mulheres não caçavam, a única coisa que faziam nesse ramo de atividade era armar arapuca para pegar passarinhos pequenos. Normalmente, as mulheres cuidavam da casa e ajudavam os homens a cuidar da roça. Seu Chico conta que o homem fazia o trabalho pesado de derrubar o mato pra roçar e a mulher carpia, cavava, plantava e colhia. Quando a mulher tinha filho pequeno, ela levava as crianças no jacá. Amarrava uma rede perto da roça para a criança poder descansar e trabalhava até o meio dia. Assim, a criança apreendia bem cedo o trabalho da roça. Costumavam imitar os mais velhos e quando tinham seis ou sete anos já sabiam pegar em uma enxada e na foice.

A agricultura era a principal atividade econômica dos Mandira. Frederico Mandira, com 83 anos é atualmente um dos mais velhos da comunidade. Ele afirma com autoridade que "hoje em dia a vida é muito fácil. Naquela época o trabalho era duro. Hoje em dia o povo tem preguiça de trabalhar". Seu Frederico associa trabalho à atividade da roça. Tal sinônimo deixa clara a constância da atividade em tempos de outrora.

Contam que antigamente, os Mandira plantavam tudo o que precisavam para seu consumo: arroz, milho, feijão, batata, cara, rama, café, banana, cana, limão, laranja, jabuticaba e outras frutas. A rama era para fazer a farinha. Seu Chico e Dona Irene Mandira contam que cada conjunto de moradia, formado por casas de familiares próximos, tinha seu tráfico de fazer farinha, composto pela roda, o forno, a prensa e o tipiti. Normalmente o tráfico ficava próximo a casa da pessoa mais velha da família.

"Quem não tinha usava o tráfico emprestado do outro. Mas ninguém cobrava nada. O que acontecia era deixar um litro de farinha como agrado 
para o dono do tráfico, mas ninguém cobrava nada. Outra coisa que é importante, é que não se vendia peixe, não se vendia caça na comunidade. Podia pescar o peixe o tanto que fosse e o pessoal da comunidade toda comia" (DIEGUES, 2005:359).

Os conjuntos de moradia eram formados por casas de parentes próximos, como pai, mãe e irmãos. As casas eram construídas de sapé, pau-a-pique, com chão de barro socado. As paredes eram amarradas com o cipó Imbé (philodendron imbe) antes de barrear e os telhados de palha eram tecidos com o cipó Timbopeva. Geralmente, os núcleos familiares assentavam-se ao lado de um curso d'água. Conduziam a água com o tronco da embaúba (cecropia pachystachya) cortado ao meio até o local apropriado para a coleta, denominado "bica". Assim, cada conjunto de moradia tinha sua própria bica para coletar água, construída com o tronco da embaúba.

\subsubsection{As viagens.}

Como em outras comunidades do Vale do Ribeira, o arroz era o principal produto de comercialização e troca. Normalmente, vendia-se o arroz para a obtenção de poucos gêneros de primeira necessidade não produzidos na comunidade, como óleo e sal. A maioria dos moradores mais velhos do Mandira lembram as viagens de canoas a remo e a vela, com as cargas de arroz para serem comercializados em Cananéia. Toda a família participava dessas viagens. Dona Saturnina conta quando preparava a canoa forrada com a esteira de peri para deitar seu filho, Reinaldo, recém nascido, no meio dos sacos de arroz, durante a viagem de canoa à cidade. Nesse tempo, as canoas aportavam

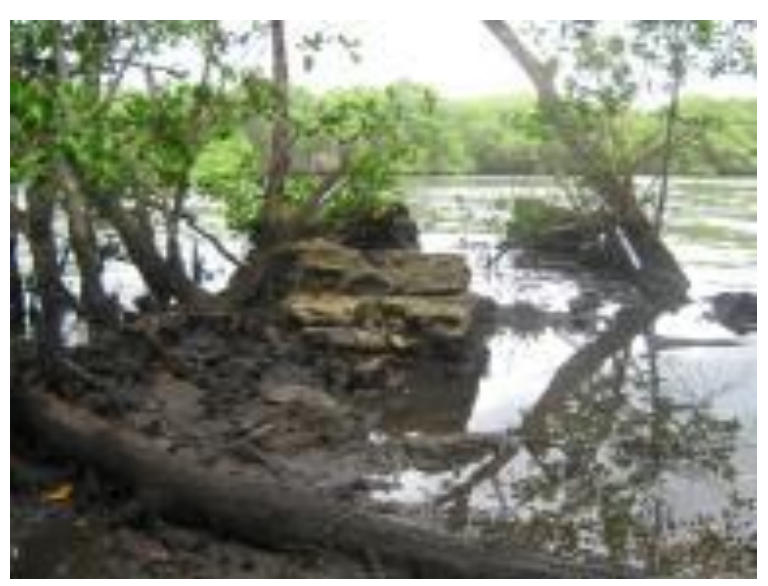
em Cananéia na prancha do antigo porto, próximo ao local da atual Balsa (ver "Mapa Panorâmico" no Anexo 2). De lá as mercadorias eram levadas de carroça até o mercado no centro da cidade.

Os antigos contam que as esteiras

Figura 3: Estrutura do antigo porto na ilha de Cananéia, ao lado da atual balsa. 
de Peri serviam para os mais diferentes fins. Com esse material era feito esteiras usadas para dormir, como camas dentro das casas, como encosto nas cadeiras, como tapete das casas e como forro nas redes. Dona Saturnina lembra que antigamente, a esteira de Peri também era usada para enrolar a pessoa falecida dentro de uma rede e levar o corpo até o cemitério de Cananéia.

Segundo os Mandira, os enterros sempre foram feitos no cemitério de Cananéia. Quando alguém morria, seu corpo era velado em casa. Depois da primeira cerimônia o corpo era envolvido pela esteira de Peri e suas pontas amarradas em um tronco. Assim, o corpo do falecido era carregado em revezamento, com uma pessoa em cada extremidade do tronco, até o porto do Mandira, para de lá seguir em procissão pelo mar, até a Ilha de Cananéia. Hoje em dia, nem o Peri, nem a canoa são mais usados. No lugar existe o caixão e a procissão até Cananéia é feita de carro.

Além do comércio de arroz e das procissões de finados, as viagens para Cananéia também eram feitas em tempos de festas. Dona Irene se lembra das viagens que fazia com seu pai, mãe e os irmãos na época da Festa de Nossa Senhora dos Navegantes: "Meu pai levava todos para a festa dos Navegantes, dia 15 de agosto. Iamos todos na mesma canoa".

\subsubsection{As canoas.}

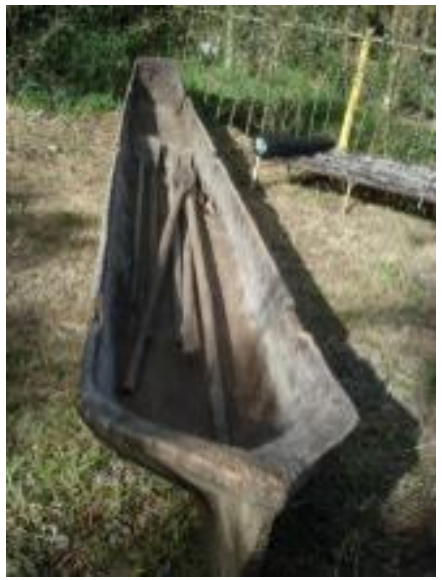

Figura 5: Canoa monóxila.
Bernardo Henrique Coutinho, pai de Seu Chico, contou que os irmãos de Dona Judith, Cesar e Cristino sempre fizeram canoa de um tronco só. Ele explicou que as madeiras boas para fazer canoa são as madeiras de cerne, que na região são conhecidas como guapiruvu, quarifica, canela, carapaçu. As madeiras mais leves são boas para barcos de pesca, já as mais pesadas como canela são boas

para canoas de transporte. As madeiras eram derrubadas com o machado bem afiado na pedra-de-amolar. Depois de derrubado o tronco era trabalhado com o próprio machado e com o enxó, ambos bem afiados. Faziam uso de três tipos de

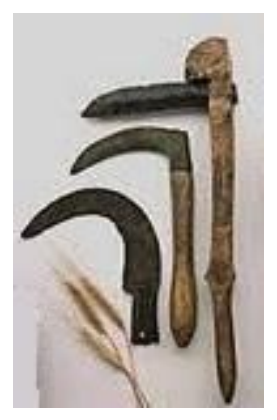

Figura 4: Enxós. 
enxó para fabricar as canoas: um do cabo grande que se fazia por cima a proa e a poupa; outro de cabo curto que moldava o tronco na parte de dentro da canoa; e o terceiro também de cabo curto que alisava o bojo da canoa.

Algumas canoas tinham um buraco no último banco da proa para colocar um mastro com a vela. As velas eram feitas de pano costurados pelas mulheres. Com uma corda amarrada à vela e percorrida no topo do mastro podia hastear as velas em poucos minutos. Outra corda amarrada na ponta da haste que mantém a vela aberta possibilita controlar a velocidade da canoa, manejando a quantidade de ar que a vela apanha. Por fim, a direção é controlada pelo remo colocada na água pela popa da canoa. As velas não são mais utilizadas, mas as canoas monóxilas ainda hoje são usadas, principalmente para a pesca e a coleta de materiais no mangue.

Para Bava de Camargo (2009), o transporte de mercadorias por canoas monóxilas aparenta uma peculiaridade da cadeia produtiva de Cananéia. Enquanto no restante do Ribeira a navegação a vapor conseguiu estabelecer uma linha contínua, que concentrava as operações de transporte ao porto marítimo ou a estação ferroviária, isso nunca aconteceu em Cananéia. Talvez pela geografia recortada e a distância em relação à Barra do rio Ribeira, as canoas monóxilas, popularmente conhecidas como canoa-deum-pau-só, não foram substituídas completamente pelos barcos a vapor, permanecendo como elos vitais na cadeia produtiva, transportando as mercadorias de pequenos agricultores aos entrepostos comerciais e engenhos e destes ao porto de Cananéia até meados de 1950 .

Bava de Camargo (2009:28) confirma que as principais atividades náuticas no Mar-de-Dentro, também conhecido como Mar de Cubatão são relativas à comercialização do arroz, que data de fim do século XVIII até meados de 1950. O autor descreve a cadeia de circulação das mercadorias que seguiam em pequenas quantidades das plantações aos locais de entrepostos ou diretamente aos engenhos, os quais recebiam diversas cargas dos arredores. Depois de beneficiado partiam diretamente para o mercado consumidor (Santos, Paranaguá, Rio de Janeiro) ou para o Porto de Cananéia, onde seria despachado com outras mercadorias em embarcações maiores.

Esse transporte de mercadorias foi sendo substituído paulatinamente pelo barco a vapor e depois pelo barco a motor. Mas a canoa monóxila é tão marcante na paisagem marítima de Cananéia que, mesmo sem as velas, até hoje as canoas são utilizadas para atividades de pesca e alguns poucos comércios entre as comunidades mais afastadas da cidade. Entre os Mandira a canoa é usada diariamente principalmente para a pesca e a 
coleta de materiais nas barras dos rios. Falaremos sobre as atividades vinculadas a pesca e coleta de material à diante.

\subsection{História da resistência.}

Segundo Sales e Moreira (1996:43-44), após o fim da primeira metade do século $\mathrm{XX}$, ocorreu entre os Mandira "fases subseqüentes de predominância de exploração comercial de um determinado recurso". Assim, apontam para o fim de um período no qual a predominância de recursos agrícolas diversificados deu lugar a maior exploração de um único produto específico, primeiro a guanandi, depois o palmito e a caixeta, culminando na exploração de ostras, atividade na qual a comunidade vem laborando há cerca de 20 anos.

Essa mudança nos costumes e hábitos dos Mandira, substituindo a atividade agrícola de produção diversificada de insumos com vistas, principalmente, para o consumo próprio, em troca da agricultura de produtos específicos, é uma tendência dos tempos modernos da globalização. Como exemplo deste vetor do mercado, os Mandira recordam-se da época recente quando a exploração de guanandi (Calophyllum brasiliense Cambess) e outras árvores de madeira nobre eram valorizadas devido a demanda comercial das serrarias do Paraná e de Pariqüera-Açu. Meados dos anos 1960, deu-se início a extração de palmito e caixeta também para fins comerciais. Impulsionada pela crescente demanda advinda da instalação de indústrias de beneficiamento nos municípios vizinhos, o palmito era recurso de alto interesse comercial, chegando inclusive a valorizar as terras onde existiam as palmeiras.

Conciliada com a tendência moderna de apropriação das terras pelo mercado, ditada pela demanda de consumo dos centros urbanos, desde meados dos anos 1970, as Legislações Ambientais também produzem considerável abalo às atividades agrícolas. Assim como outras comunidades caiçaras de Cananéia, Iguape, Jureia, Peruíbe e Paranaguá, os Mandira sofrem com as políticas públicas do meio ambiente. Segundo Diegues (1998), em decorrência destas políticas ambientais as coletas de palmito e caixeta passaram a ser proibidas. Isso, associado com a criação das Áreas de Proteção Ambiental e dos Parques Estaduais, determinou o declínio da agricultura tradicional e a grande desestruturação na organização social das comunidades agrícolas. 
Fatos como estes infelizmente não ocorrem com exclusividade no Vale do Ribeira. O mesmo processo de desapropriação das terras que comunidades inteiras costumavam explorar observa-se nos relatos históricos dos moradores do quilombo do Açude, em Minas Gerais, com a comunidade quilombola do Carmo, em São Roque-SP, com a população do quilombo de Boa Vista do Pixaim (também conhecida como comunidade do Curral), no interior da Bahia ${ }^{17}$, e em muitos outros quilombos de todo o Brasil, onde os quilombolas são impedidos de trabalhar ou ocupar suas terras originais, sendo confinados em pequenas glebas "oferecidas" pelos novos proprietários (geralmente adquirida a título de grileiros) ou fornecidas pelo poder público em ações de remanejo.

Com os Mandira ocorre o mesmo processo de desapropriação das terras. $\mathrm{Na}$ década de 1970, a comunidade sofreu uma segregação no seu próprio território. Esse ocorrido é descrito por Turatti (2002), como uma "transformação" de seu território causado pelo deslocamento forçado do local de origem da vila dos Mandira, caracterizado como tentativa de expulsão dos Mandira de seu território ${ }^{18}$.

Segundo Seu Chico, o Sítio Mandira agregava originalmente cerca de 1.200 alqueires (2.900 hectares) de terras. Com a divisão entre os dois irmãos coube a cada um deles a metade das terras (cerca de 600 alqueires), tendo o Salto do rio Mandira como marco divisor. Contam ainda que, após o falecimento de Antônio Vicente Mandira, seus familiares venderam suas terras paulatinamente e não existem mais contatos entre estes e os atuais ocupantes do Mandira. Já os descendentes de João Vicente Mandira permaneceram na porção do território que lhes cabia.

Assim, os descendentes de João Mandira se expandiram e ocuparam as terras a baixo do salto do rio conforme seus interesses e necessidades. $\mathrm{Na}$ medida em que os mais velhos faleciam, outros adquiriam o papel de resguardar e afirmar a união da comunidade. Entre os líderes, uma das figuras mais lembrada é a de João Vicente Mandira Filho, filho mais novo de João Vicente Mandira. Conhecido como Jango, ele foi referência na comunidade durante muito tempo. Desenvolveu a mediunidade e implantou a prática do espiritismo entre os mandirenses. Tornou-se um forte curandeiro

\footnotetext{
${ }^{17}$ Informações levantadas por mim, em viagens às comunidades quilombolas citadas durante os anos de 2004 à 2007.

${ }^{18}$ Segundo deixa claro no Relatório Técnico-Científico, Maria Cecília Manzoli Turatti descreve esses fatos balizada em informações coletadas pelo trabalho de campo antropológico e documentos oficiais, como certidões do Cartório de Registro de Imóveis de Cananéia (TURATTI, 2002). Tais informações, também foram devidamente confirmadas pelo trabalho de campo etnoarqueológico, inclusive localizando os locais dos núcleos das antigas moradias. Trataremos disso ao longo do texto.
} 
usando ervas e benzimentos para tratar as enfermidades do corpo e da alma. Sua habilidade era reconhecida em toda a região.

Quando Jango faleceu, na década de 1960, seu herdeiro Amâncio Mandira ficou como porta voz da comunidade. Com este status de liderança, Amâncio foi persuadido por dois intermediários - um corretor imobiliário da cidade de Registro e um policial florestal - da necessidade de venda das terras devido às péssimas expectativas de continuidade das práticas comunais. Vale lembrar novamente, que a área aqui descrita é apenas a porção de terras do sítio Mandira correspondente a João Vicente Mandira, ou seja, metade da área original do sítio Mandira.

Assim, Amâncio convenceu os outros membros da família a venderem as terras aos dois pretendentes compradores, Affonso Antonio Di Trani Splendore e Aluísio de Assis Buzaid. Entretanto, alguns membros da comunidade recusaram-se a negociar suas terras e tentaram convencer os parentes a desistirem da idéia. Segundo as lembranças dos moradores mais velhos, Amâncio já havia se comprometido com a venda e sofria ameaças de perseguição e morte caso desistisse do negócio. A solução foi vender e se mudar com os parentes próximos e alguns outros familiares para o bairro de Porto Cubatão ${ }^{19}$.

Mesmo assim, onze famílias resistiram à venda e permaneceram nas terras, procurando superar todo tipo de adversidade. Splendore e Buzaid adquiririam as terras referentes às partes que cabiam aos familiares que se mudaram para Porto Cubatão, por meio de um tratado de aquisição de terras, deixando a outra parte aos que resistiram à venda. Consta no Cartório do Registro de Imóveis da Comarca da Jacupiranga sob a matrícula 4027, menção a inscrição número 1174 , do livro 4-B, do mesmo cartório, referente ao contrato particular de compromisso de compra e venda de parte do imóvel à Splendor \& Buzaid Ltda. Assessoria Integrada, datado de 24 de janeiro de 1975 (ver Registro de Imóveis Comarca de Jacupiranga reproduzido como imagem no Anexo 2). Assim, em 14 de dezembro de 1977, podemos verificar na mesma matrícula, sob a Forma do Título no. 4346, o imóvel com área de 605.124 alqueires paulista ficando pertencendo integralmente aos senhores mencionados acima. Mais curioso, que na

\footnotetext{
${ }^{19}$ Porto Cubatão é o bairro de maior infra-estrutura na parte continental do município de Cananéia. Distante aproximadamente $20 \mathrm{kms}$. do Mandira, na beira do Mar de Dentro (ver "Mapa Panorâmico" no Anexo 1), ele foi constituído historicamente por ser o primeiro local de travessia da Ilha, onde hoje é o local da Balsa (ver ALMEIDA, 1963:94-98). O bairro conta hoje com a escola estadual de ensino médio que atende todos os jovens das comunidades do entorno, posto de gasolina e um condomínio fechado, fatores que oferecem mais opções de trabalho aos moradores, além da proximidade com o centro de Cananéia.
} 
mesma matrícula, na averiguação no. 6, datada de 25 de setembro de 1978, referente a matrícula no. 5069, registro no 1 , foi transmitido 56 alqueires paulistas (igual a 13.55.200 m2) do mesmo lote de terra a Maria Egidia Mandira, Florindo Mandira, Arnaldo Mandira, Frederico Mandira, Antônio da Silva Mandira, Cristino Mandira, Angelo Mandira, Judite Mandira, Elza Mandira Alves, Algusta Mandira e Saturnina Mandira de Oliveira (ver folha 2 e folha 2 verso do Registro de Imoveis da Comarca de Jacupiranga no Anexo 2).

Conforme podemos ver nos registros da matrícula 4027 do Livro 02 do Registro Geral da Comarca de Imóveis de Jacupiranga (ver Anexo 2), os cálculos e critérios de distribuição das terras não são muito claros, pois a unidade do alqueire não segue um padrão, variando entre alqueire (que parece ser o equivalente a $10 \mathrm{mil} \mathrm{m} 2$ ) e alqueires paulistas (que apresenta uma variação em torno de 24 mil m2). Segundo Turatti (2002), os trâmites legais realizados pelas pessoas físicas de Splendor e Buzzaid na compra das terras do Mandira não seguiram o estabelecido pelo contrato particular de compromisso de compra e venda desse imóvel que estabelecia a venda de apenas metade das terras. Para a pesquisadora, Splendor e Buzzaid alegaram que foi subtraída parte das terras como forma de pagamento das despesas com os encargos jurídicos e cartoriais para a legalização final dos títulos de domínio de toda a área. Feito isso, os supostos compradores, subitamente transformados em vendedores das terras demarcaram os 56 alqueires paulistas remanescentes do território Mandira em lotes iguais distribuídos para cada um dos herdeiros de maneira individual, em conformação espacial absolutamente aleatória e totalmente estranha ao modo de ocupação anterior.

Desta forma, os Mandira que resistiram a venda das terras e permaneceram em seu território foram iludidos pelo processo de regularização de suas terras e transformados pelo documento de "Compromisso de Compra e Venda" em compradores de suas próprias terras. Os resistentes Mandiras, totalmente vulneráveis e submetidos às determinações dos especuladores só poderiam receber os alqueires referentes às partes que lhes cabiam se estes fossem localizados em uma das extremidades do território geral. Os novos proprietários não queriam os quilombolas habitando o meio de suas terras, por isso forçaram os que permaneceram no território a abandonarem suas casas, habituais áreas de plantio, os locais entre mangues e perto do rio Mandira utilizados de porto das canoas e todos os espaços habitados, para ocuparem outra área na extremidade do território. 
Na memória dos moradores ainda está vívida a lembrança das ameaças sofridas para abandonar suas casas e as terras produtivas e se deslocarem para glebas de terras periféricas. Em seguida ao fato, muitos membros dos Mandira venderam seus lotes, pois não resistiram ao processo de adaptação à nova localidade, além das fiscalizações cada vez mais intensas movidas pelos empecilhos impostos pela legislação ambiental. As pessoas que venderam seus lotes foram viver no bairro de Porto Cubatão, onde hoje vivem muitas famílias de sobrenome Mandira ${ }^{20}$.

Enganados e desestruturados com a fragmentação de suas terras em lotes individuais, os Mandira que não abandonaram seu território, honram sua história de resistência. Atualmente, permanecem na luta para que seja revisto essa injustiça histórica e assim possam voltar a habitar e decidir a melhor forma de explorar o território como herança de seus antepassados e referência de suas histórias.

\subsection{Histórico atual.}

O que inicialmente era um sítio de quase 3 mil hectares, depois uma área dividida em duas porções de 600 alqueires paulista (1.344 hectares), reconhecida pelas comunidades vizinhas, hoje se reduz quase exclusivamente a um assentamento da área residencial e a área da Reserva Extrativista (na qual falaremos a seguir), totalizando aproximadamente 22 alqueires (53,2 hectares). Entretanto, é neste ambiente bem conhecido e explorado que as mais de vinte famílias do Mandira permanecem vivendo e contando suas histórias.

Privados de fazer roça, os Mandiras compram no mercado da cidade a maioria dos produtos que consomem. A agricultura não é mais praticada como antes. Porém, se por um lado o trabalho agrícola não faz mais parte da vida ativa da comunidade, a pesca, por outro, é fundamental. A área de enclave da comunidade é bastante piscosa e os moradores fazem da pesca caiçara uma tradição conduzida por muitos mandirenses. Os rios nomeados pela comunidade como rio da Camboa, rio Boacica, rio Marimbondo, rio Preto, rio Mandira e outros, além das áreas de mangue (hoje utilizadas mais para a extração de ostras), são meandros intensamente aproveitados em atividades pesqueiras,

\footnotetext{
${ }^{20}$ Hoje em dia algumas destas famílias querem voltar a ocupar o Território Mandira, tendo em vista as melhorias e perspectiva de titulação das terras. Entretanto, enfrentam a falta de reconhecimento dos atuais habitantes do Mandira por não terem passado pelo processo de resistência às terras e a mágoa pelo abandono.
} 
especialmente para a obtenção de alimento, que "delimitam esta área de importância fundamental para a manutenção sócio-econômica da comunidade tanto no passado quanto no presente" (TURATTI, 2002:26).

\subsubsection{A pesca.}

A pesca sempre foi prática tradicional entre os Mandira. Dizem que antigamente era fácil pescar, bastava esticar a rede de dentro da canoa e bater com o remo na água que a tainha pulava e caia dentro da canoa. As redes também não eram como as de hoje, confeccionadas com linha caseira, bastava um laço de arrasto para apanhar bagre, pescado, robalo e todo tipo de peixe. A malha era maior que as de hoje em dia, por que não se apanhava peixes pequenos.

Antônio Carlos Diegues (1973:187) define a pesca caiçara como uma modalidade de pesca artesanal, cujos pescadores trabalham sozinhos ou utilizam mãode-obra familiar com produção destinada total ou parcialmente ao comércio. $\mathrm{O}$ autor menciona ainda que os pescadores artesanais exploram ambientes localizados próximos à costa, pois a embarcação e aparelhagem utilizadas para tal possuem pouca autonomia.

A captura e o desembarque de toda a classe de espécies aquáticas são feitos através de técnicas transmitidas entre gerações, direcionadas mais para a seleção das espécies capturadas, do que para o alto rendimento relativo. Muito difundido entre os

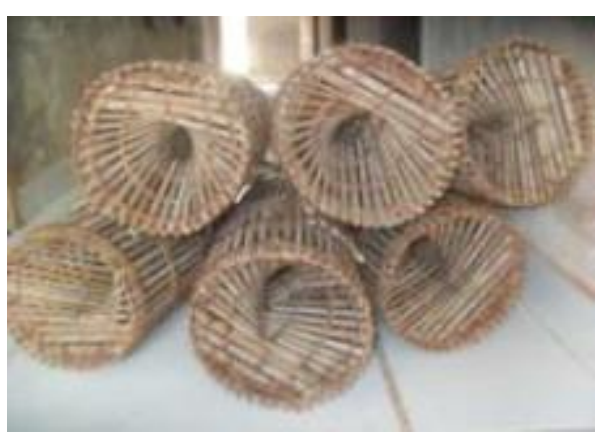

Figura 6: Covos.

Fonte da figura:

http://produto.mercadolivre.com.br/MLB434870782-covos-de-bambu-pesca-armadilhaotima-camaroes moradores do litoral, o covo e o juquiá são exemplos típicos de armadilhas tradicionais de pesca caiçara.

O covo é confeccionado com uma sequencia de vara de taquara, amarradas em formato cilíndrico com barbante, arame ou cipó imbé. Um dos lados é tampado para servir de fundo da armadilha. No outro lado é colocado um funil invertido de menor extensão (denominado por eles de filho), de modo que ocupe no máximo metade da área interna do

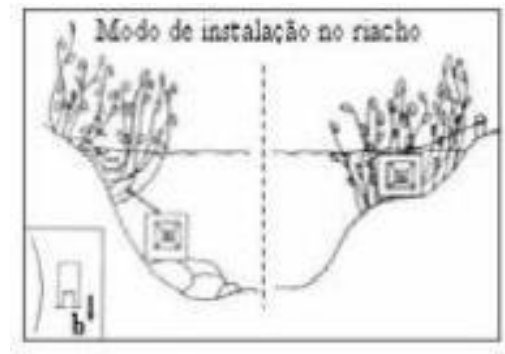

Boca voltada na diroçlo da correnteza (b)

Figura 7: Modo de posicionar o covo. 
cilindro e sua entrada seja amarrada no lado aberto do cilindro. Com a abertura posicionada na mesma direção que a correnteza, a armadilha fica submersa, colocada estrategicamente na borda das águas dos pequenos rios, riachos e canais, com uma isca na parte interna para atrair o peixe. O tamanho da saída do funil seleciona o tamanho dos peixes que entram no covo e não conseguem mais sair.

O juquia é mais simples. Feito com os mesmos materiais possui o formato semicilíndrico, com o detalhe de uma degola no meio do corpo do objeto, que funciona para selecionar o tamanho da presa. A armadilha é colocada contra a correnteza, assim o peixe que entra não consegui sair. Trata-se de uma captura passiva dos peixes, pela qual a armadilha não necessita ser movida ativamente. A coleta é determinada pelo tempo da correnteza, podendo ser feita horas ou até dias (dependendo do lugar) depois de ser instalada.

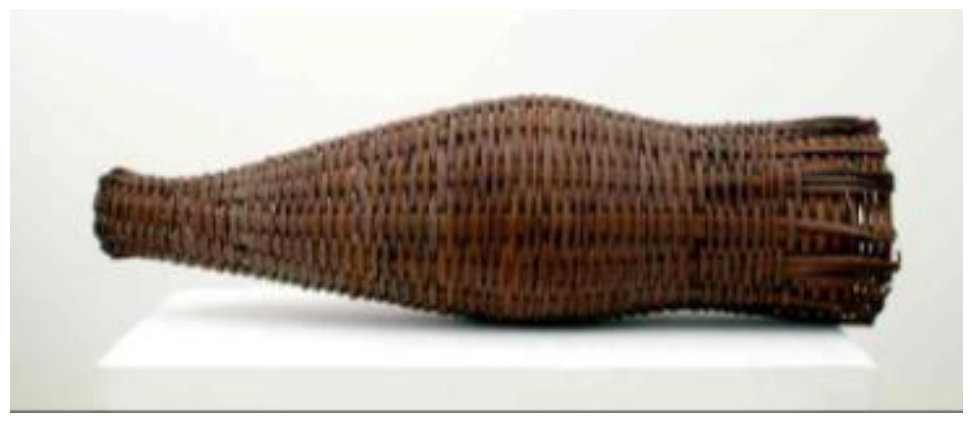

Figura 8: Juquia.

\subsubsection{Cooperostra.}

Apesar dos Mandira não dependerem mais da pesca artesanal para sobreviver, é da atividade pesqueira que vem a maior fonte de renda para a comunidade: da extração e comercialização de ostras. Apoiados por instituições de pesquisa como o Núcleo de Pesquisa sobre Populações Humanas e Áreas Úmidas Brasileiras (NUPAUB-USP) e o Centro Nacional de Desenvolvimento Sustentável de Populações Tradicionais (CNPT/IBAMA), moradores do Mandira participaram de uma avaliação técnica, na década de 1990, que apontou a viabilidade do projeto de implantação de uma Reserva Extrativista contígua ao território. Os Mandira concordaram com a implantação do projeto Reserva Extrativista dos Mandira, (RESEX Mandira), oficializado pelo IBIO/IBAMA, que configurou como área núcleo do Projeto de Ordenamento da Exploração de Ostras no Mangue. Na mesma época, foi criada a Associação dos 


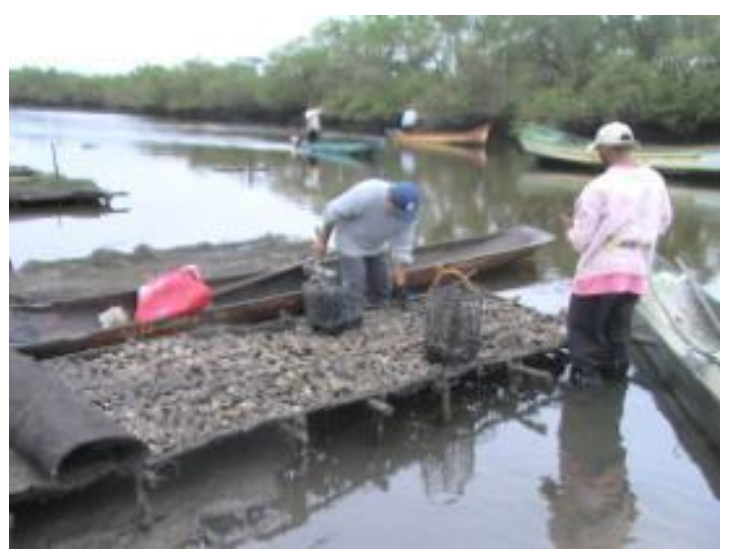

Figura 9: Atividade no viveiro de ostra.

Moradores da Reserva Extrativista dos Mandira (REMA) e a Cooperativa dos Produtores de Ostras de Cananéia, a Cooperostra, com auxílio de planejamento e gestão da Fundação Florestal em conjunto com o Instituto de Pesca, Comissão Pastoral dos Pescadores, Fundação Botânica Margaret Mee, Instituto Adolfo Lutz, Coordenadoria de Planejamento Ambiental da Secretaria do Meio Ambiente-SP, ONG Visão Mundial e o Programa Estadual para a Conservação da Biodiversidade (PROBIO-SP).

Com sua grande maioria formada por membros do Mandira, a Cooperostra já conta com dois barcos, carro e uma sede construída em mutirão compondo telefone, computador, internet e materiais de escritório. Esta sede é onde ocorre o beneficiamento e a embalagem das ostras.

Como principal fonte de renda, a maior concentração de energia da comunidade quilombola é direcionada à extração, manejo e comercialização das

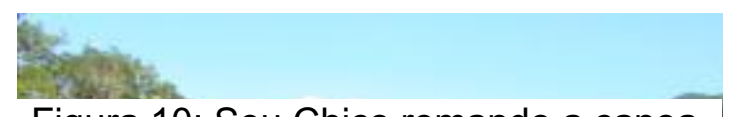

Figura 10: Seu Chico remando a canoa.

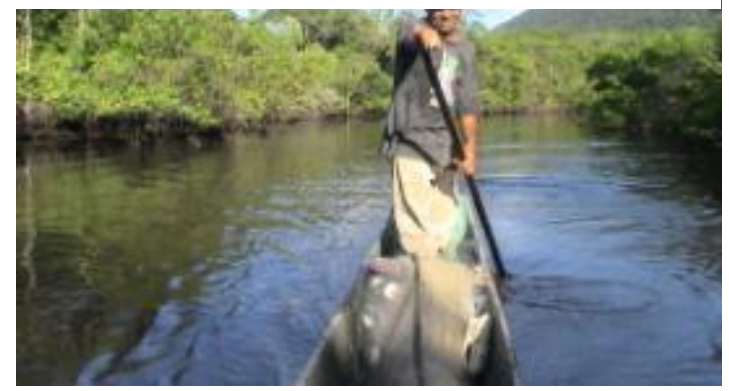
ostras. A rotina dos membros é ditada pelo trabalho com a ostra, que por sua vez depende do período da maré vazante para coletar as ostras no mangue ou manejá-las nos viveiros.

Assim, nos primeiros dias da semana, os Mandira membros da Cooperostra, "vão à maré", como denominam o período de trabalho do manejo da ostra nos mangues. Rumam ao porto de onde apanham as canoas e se direcionam aos viveiros. Precisam sair na maré vazante para encurtar o caminho e trabalharem nos viveiros ou nos mangues com a maré baixa. $\mathrm{O}$ trabalho mais penoso é remar o barco até o local no mangue onde as ostras são coletadas. Saber qual o melhor lugar para a coleta da ostra faz parte da sabedoria e experiência do pescador. Geralmente os mais experientes se sobressaem nesse requisito. 


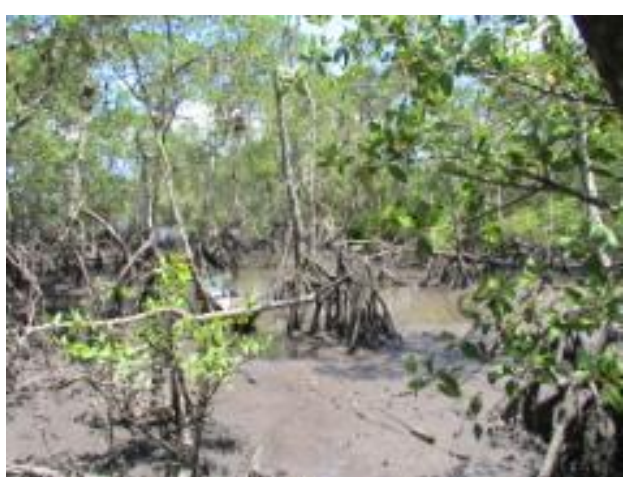

Figura 11: Manguezal.

No mangue o trabalho também não é fácil. As canoas são amarradas na beira do mangue e os indivíduos se lançam mangue a dentro. Utilizando foice, facão, botas e balde, as raízes das árvores são agilmente examinadas e as ostras coletadas e armazenadas em baldes. Caminhar no mangue não é fácil e conhecer o ambiente para saber quais ostras podem ser coletadas é essencial para o manejo adequado. Já na canoa, as ostras são transferidas para os sacos. Precisa-se de três a quatro baldes cheios para completar um saco. Depois de um ou mais sacos completos, as ostras são levadas ao viveiro, onde permanecem até atingir o tamanho certo para serem comercializadas.

Cada cooperado tem seu próprio viveiro. Alguns cooperados podem vir a compartilhar os viveiros na intenção de potencializar a produção. Isso normalmente acontece entre membros da mesma família nuclear, ou entre as mulheres, que são minoria entre os cooperados. O trabalho na maré é dispendioso e no inverno torna-se mais penoso. Normalmente, é exercido pelos homens, apesar de algumas mulheres também participarem. Mas como o trabalho envolve a pesada tarefa de remar as canoas, elas optam por realiza-lo sempre na companhia de uma figura masculina da família.

Ainda no viveiro, os pescadores fazem a tarefa de "bater as ostras", ou seja, retirar as cracas que ficam presas na parte externa das cascas. As ostras "limpas" são ensacadas e encaminhadas para comercialização.

Nas quartas-feiras todos carregam o barco da cooperativa com seus sacos de ostras, para o cooperado escolhido levar as ostras até a sede. Quando os cooperados de

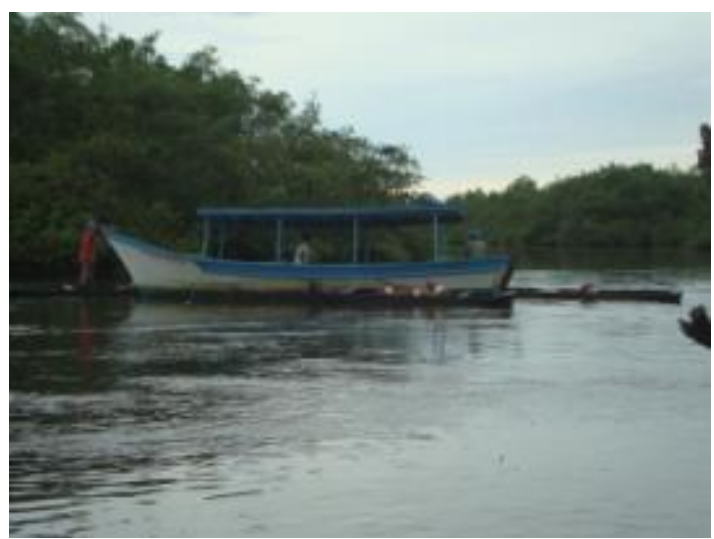

Figura 13: Embarcando os sacos de ostra no barco da Cooperostra

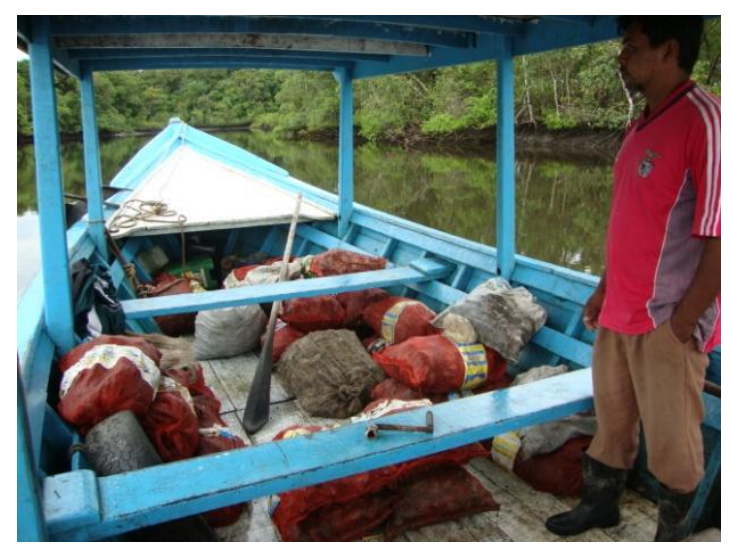

Figura 12: Sacos de ostras no barco da Cooperostra 
fora da comunidade quilombola não levam suas porções de ostras direto para a sede da Cooperostra, suas ostras são coletadas durante este percurso. Em uma das etapas da pesquisa de campo, pudemos conferir outros dois núcleos de cooperados fora do Território Mandira: o bairro do Retiro e de Itaquarí.

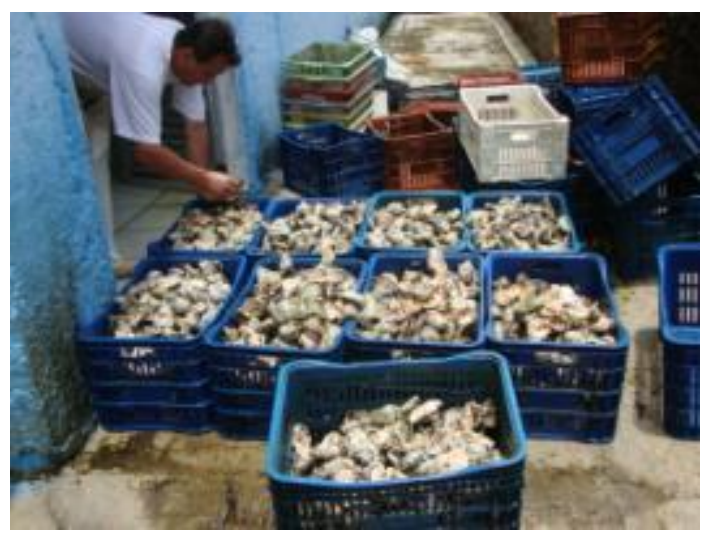

Figura 14: Ostras sendo contabilizadas.

Já na sede da Cooperostra as ostras são contabilizadas, lavadas e embaladas. Todo este trabalho é feito até quarta-feira, pois na quinta e na sexta acontecem as entregas das encomendas em residências e empreendimentos nas cidades de Santos, São Paulo, Guarujá, Bertioga, São Sebastião e Ilha Bela.

\subsubsection{0 vilarejo.}

Segundo Seu Chico Mandira, hoje em dia a comunidade possui uma maior prosperidade comparada com a complicada situação em que eles se encontravam há dez anos. Apesar de ainda hoje os jovens serem obrigados a se deslocar 20 quilômetros para terem acesso à escola de ensino fundamental e médio e ao posto de saúde mais próximo, no bairro de Porto Cubatão, a comunidade já conta com uma escola que oferece ensino básico e o serviço de ônibus escolar, que faz o trajeto três vezes ao dia, buscando e levando alunos para a escola. Por outro lado, ainda faltam atendimentos básicos do serviço público municipal, como por exemplo, a coleta de lixo que é feita apenas duas vezes por mês e linha de ônibus circular que não seja vinculada a escola.

Dona Irene, mulher de Seu Chico, conta que a luz elétrica só chegou à

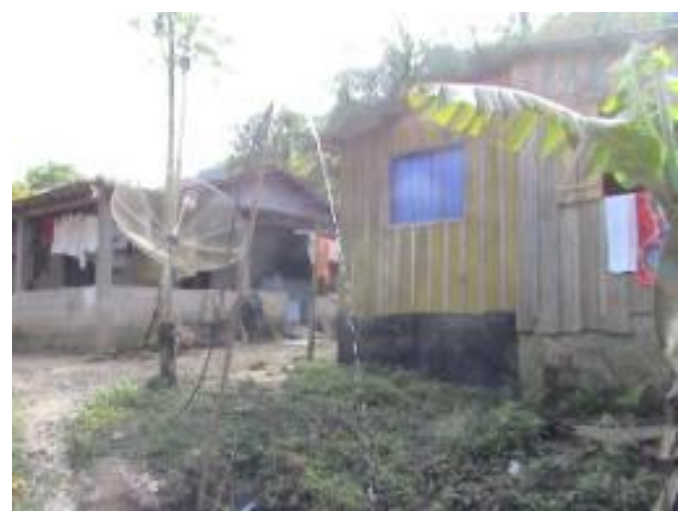

Figura 15: Bica com cano PVC nas casas. comunidade nos anos 1980, quando eles já tinham se mudado do antigo local de assentamento. Hoje todos têm geladeira e televisão. As casas não possuem sistema de 
saneamento básico da SABESP. A água é coletada nas nascentes no topo do morro, atrás da vila, e conduzida por canos de PVC. Ainda permanece a prática de se construir bicas, apesar de não serem utilizadas como antes, pois as casas já possuem sistema de encanamento da água.

Apesar de existirem mandirenses habitando outros dois núcleos de moradia nas imediações do território Mandira, onde encontramos membros da família Mandira casados com pessoas das famílias vizinhas, ${ }^{21}$ no território Mandira existe atualmente três núcleo de moradia, localizado no sopé do Morro Mandira, que por sua proximidade podemos chamar de vila. Este vilarejo é composto por menos de 20 casas distribuídas entre três concentrações de moradia.

Em cada um dos núcleos habitacionais existe uma construção de uso coletivo:

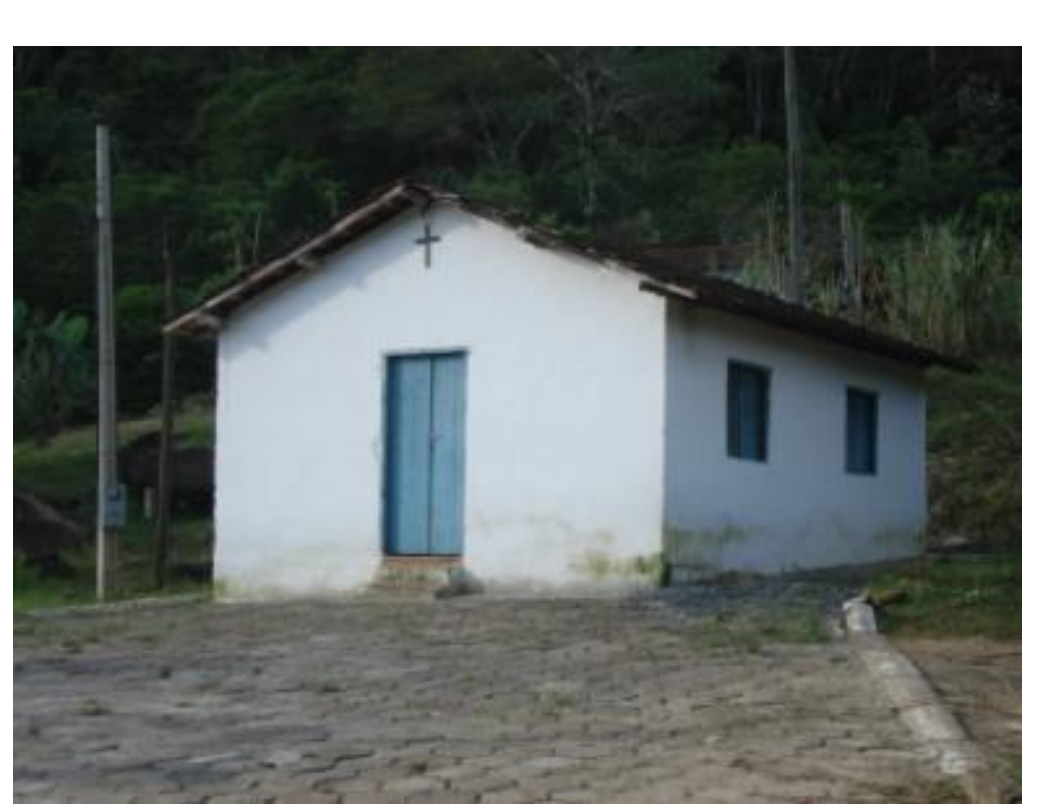

Figura 16: Igreja do Mandira.
No primeiro encontramos o campo de futebol. No outro núcleo de moradia existe a quadra de futebol de salão e a capela. A capela (também chamada de igreja) do Mandira foi construída em 1982, inicialmente de madeira. Depois ela foi reformada, construída de alvenaria em formato quadrangular, com duas

águas no telhado de cerâmica. Sua arquitetura simples comporta duas janelas em cada lateral e uma estreita porta frontal com dois degraus de acesso. Como em outras comunidades quilombolas a igreja é um ponto de referência entre os Mandira, local histórico de celebrações religiosas e guardião de imagens e objetos simbólicos à comunidade.

\footnotetext{
${ }^{21}$ Esse é o caso de Dona Saturnina Mandira casada com Seu Rubens Oliveira, vivendo no Porto do Meio e de Inácio Mandira (filho de Seu Chico e Dona Irene) casado com Rose, vivendo no sítio Boacica.
} 


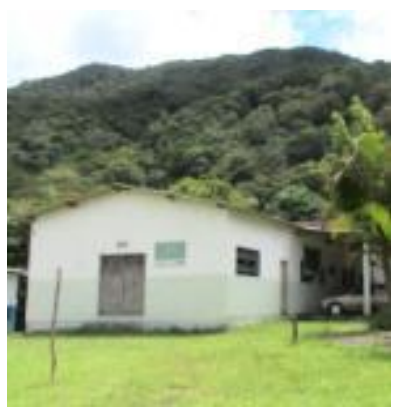

Figura 20: Galpão com teatro.

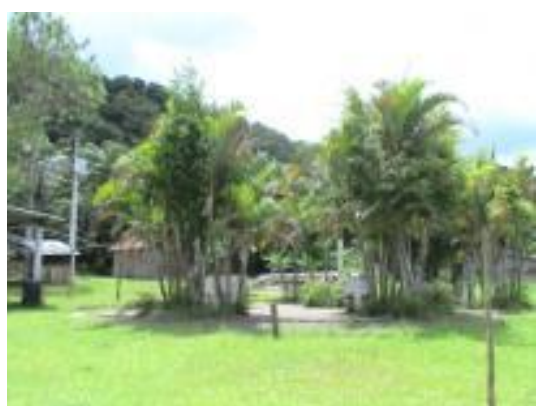

Figura 19: Praça.
No

núcleo

habitacional central existe as maiores construções comunitárias: a praça, toda feita de alvenaria em formato quadrangular, com quatro bancos no

entorno, envolvida por coqueiros e uma iluminação ao centro. O galpão grande construído para ser um teatro, possui palco e dois banheiros um de cada lado do palco na parte interna. Possui formato retangular, pé direito alto e telhado de zinco, com uma porta frontal e degraus de acesso, vitros laterais na parte alta da construção e uma cozinha comunitária aos fundos. A cozinha é interligada com o galpão por uma porta

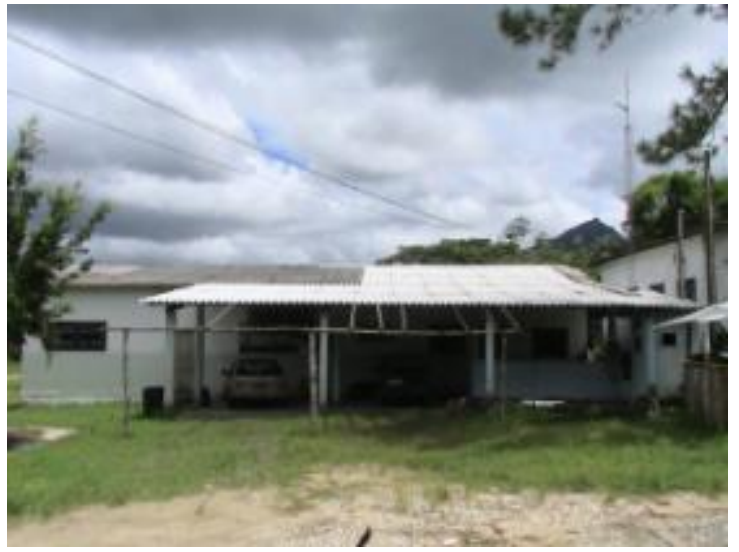

Figura 18: Cozinha comunitária.

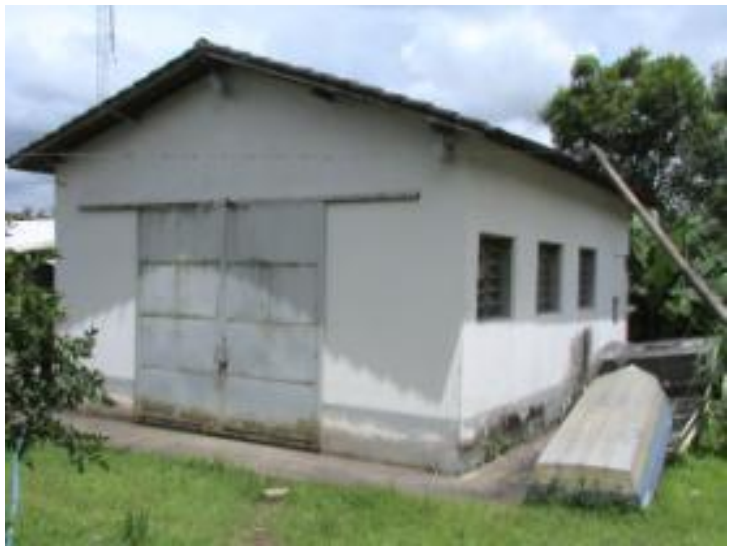

Figura 17: Barracão de costura.

localizada atrás do palco e com a parte externa por uma porta localizada aos fundos da construção. Existe ainda uma janela-galpão na lateral da cozinha. Próximo a cozinha encontramos o barracão da associação. O barracão também de alvenaria é quadrado, com pé direito alto, telha de amianto e três janelas na parte alta das laterais. Uma porta de correr de mais de dois metros na frente, com os fundos fechados, onde possui um banheiro interno.

Como as casas estão na vertente baixa do morro, as ruas do vilarejo são pavimentadas com cascas de ostras para conter a terra em dias de chuva e facilitar a entrada e saída dos carros. Os Mandira preferem as cascas de ostras ao invés dos seixos de pedras para essa função, pois as pedras são levadas com a água da chuva, enquanto 
as cascas de ostra permanecem no lugar declinado, apesar de muitas vezes rasgarem os pneus dos carros e bicicletas.

As cascas de ostras usadas para pavimentar as ruas são retiradas dos casqueiros existentes atrás das casas. Esses casqueiros foram formados na época em que não existia a cooperostra e os Mandira precisavam desmariscar as ostras para vender apenas os mariscos. A

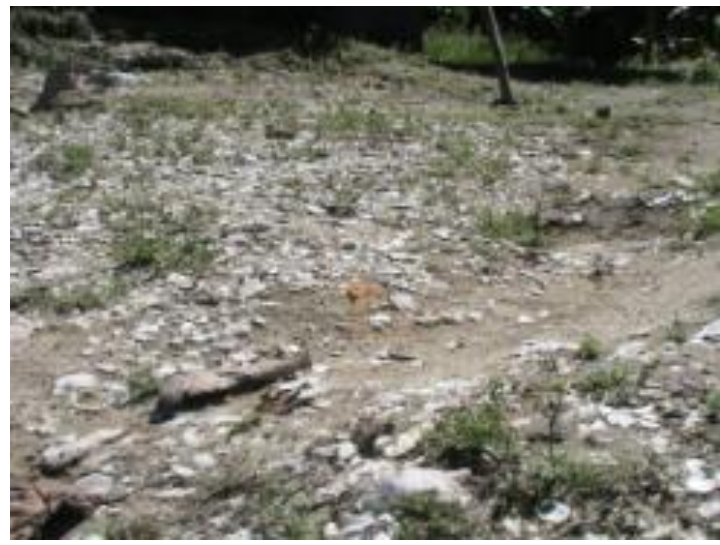

Figura 21: Ruas pavimentada com casca de ostra. atividade de desmariscar ocorria duas ou três vezes por semana com todos os membros da família trabalhando e o rendimento era baixo. A quantidade de cascas de ostras que

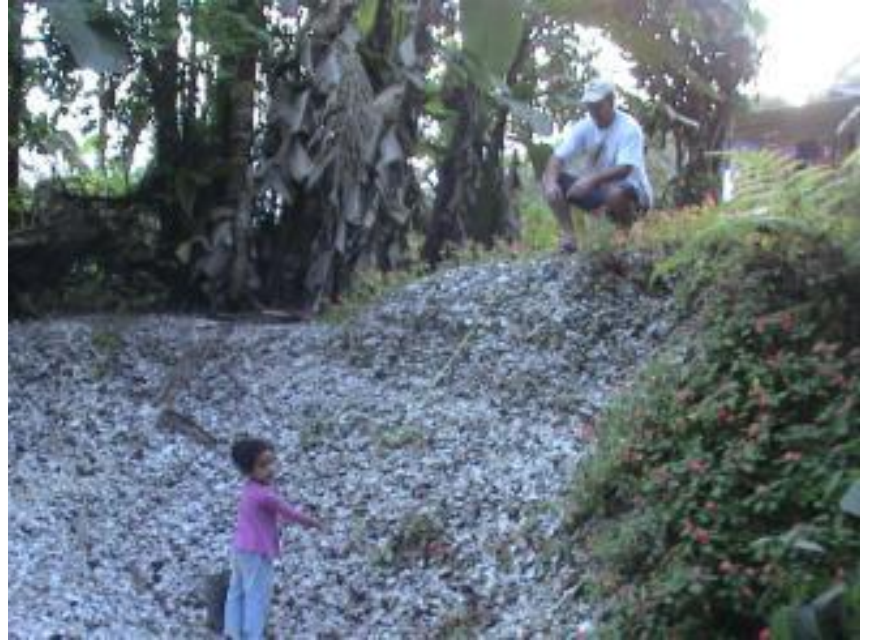

Figura 22: Casqueiro sendo medido com ajuda da pequena Gabriela. se acumularam nos fundos da casa durante os anos formou uma montanha de aproximadamente um metro de altura, com formato côncavo e uma base circular de um metro de raio. Hoje esse casqueiro é usado como mais uma fonte de recurso, na venda esporádica das cascas de ostras para empresas que revendem o material para a fabricação de pastas de dente e outros produtos.

Nos últimos 20 anos as casas do vilarejo vem sofrendo alterações. O que antigamente eram em sua maioria casas construídas de barro, pau-a-pique, ou com pranchas de madeiras alinhadas umas as outras tanto nas paredes como no chão, hoje em dia vem sendo substituídas por

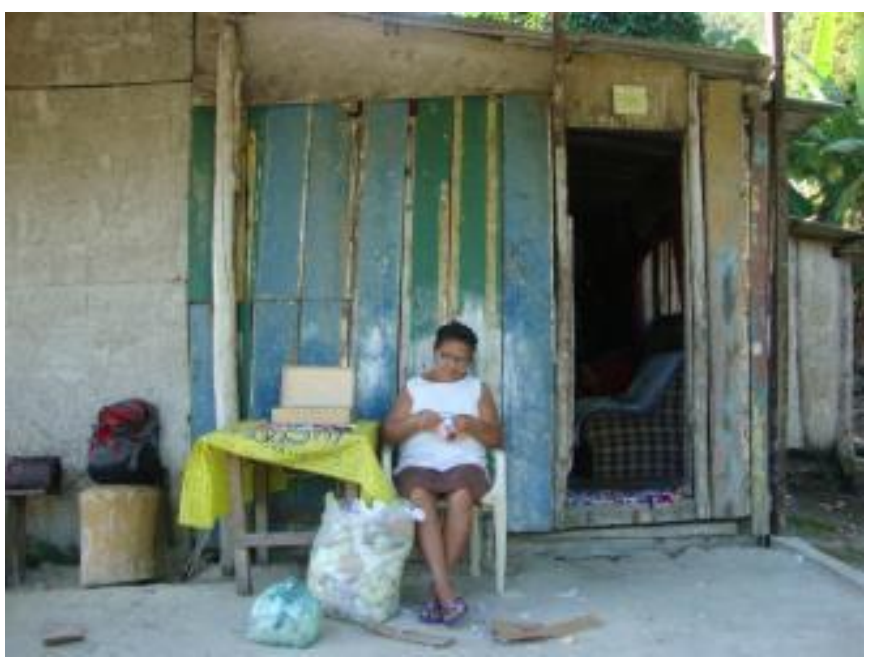

Figura 23: Casa de Seu Jango e Dona Creusa. 71 
casas de alvenaria e telhas de cerâmica. Com a proibição da extração de madeira e do barro, aliado ao fetiche comercial das casas construídas de cimento, atualmente a maioria dos Mandira importam todo o material de fora do seu território para construir as casas de alvenaria, cobertas de telhas.

Ainda restam algumas casas de madeira construídas pelo próprio morador ou por algum parente. Nestes casos são utilizados recursos do local, tais como as madeiras de lei para fazer as pranchas das paredes e as vigas e pilastras dos telhados, mas, na maioria das vezes, são obrigados a pagar pelo trabalho especializado de corte e plaina das pranchas.

Aparentemente, as construções não seguem um padrão próprio. São casas de três ou quatro cômodos, construídas quando os filhos saem da casa dos pais para casar. Posteriormente, as casas são ampliadas com os puxadinhos, conforme a família aumenta. Com o tempo, o telhado é trocado e os puxadinhos são incorporados aos outros cômodos da casa, que pode ser ampliada com varanda e garagem para os carros. Existem também as casas no início da média vertente do morro, onde não chega carro e não tem garagem ou sequer varanda. Mas em todas as casas existe uma área de serviço, geralmente próxima a cozinha.

Existem duas técnicas utilizadas para construir as casas na vertente do morro: a técnica mais prática consiste no nivelamento do piso superior utilizando toco de tronco bruto ou vigas de cimento como alicerce, compondo um porão, com acesso pela parte externa da casa, utilizado para guardar utensílios diversos; o segundo método é fazer um corte no terreno com a retirada de terra, nivelando o piso. Esse método já era utilizado nas casas de pau-a-pique com o chão batido de barro.

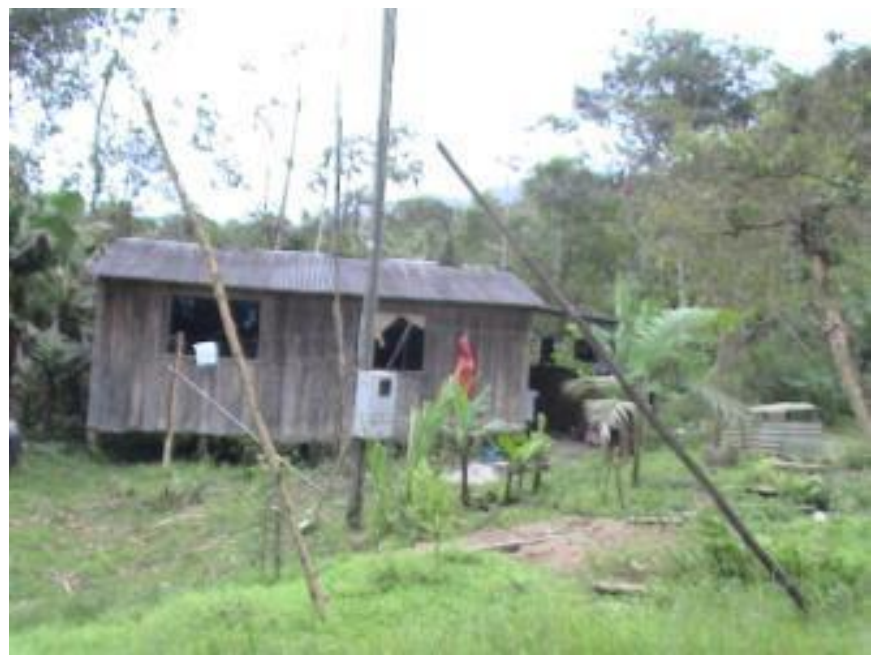

Figura 25: Casa de madeira com piso suspenso.

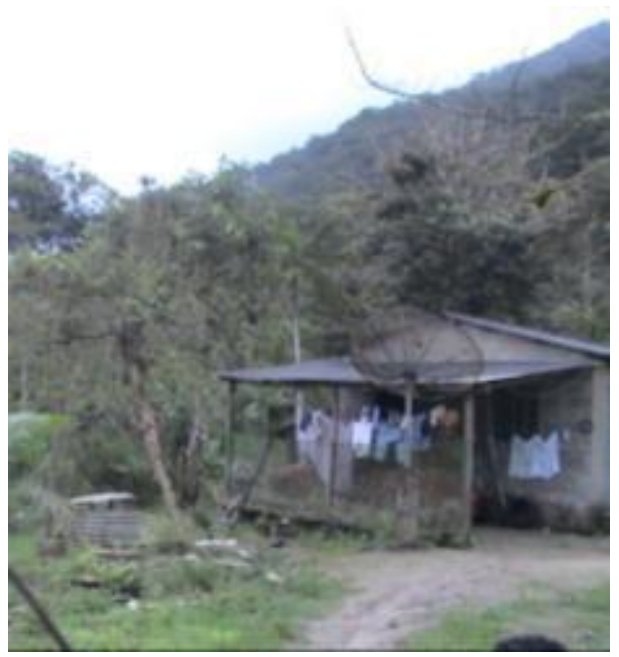

Figura 24: Casa de alvenaria com corte do terreno. 
Outro material utilizado, principalmente em construções de espaço coletivo, como bares e quiosques de festas, são os bambus. Muito utilizados, os bambus são ornados junto aos troncos de madeira compondo muretas, balcão, paredes e acabamentos do telhado de amianto. O Bambu é um material em abundância no território e seu uso é livre, todos podem cortar e usar o

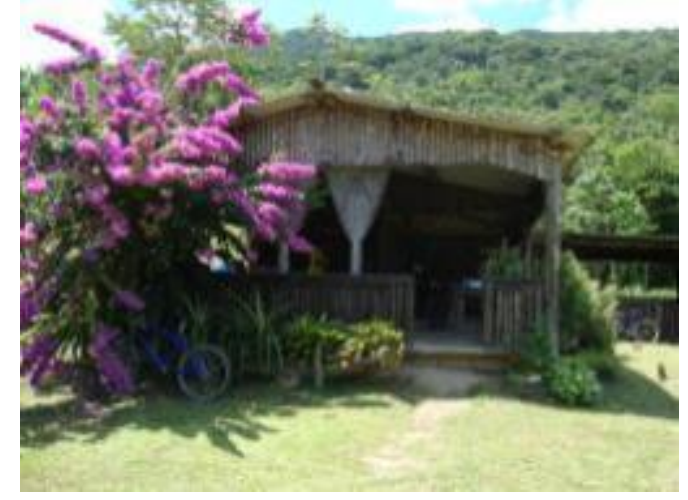

Figura 26: Construção utilizando o bambu. bambu sem restrição. Mas existe o alerta de que não se pode plantar bambu, pois acreditam que a pessoa que plantar bambu morre cedo ou vai embora da região e nunca mais volta.

Nas vilas, encontramos muitos materiais dispostos nas varandas ou no entorno das casas. Tratam-se de materiais diversos que não tem mais utilidade, como louça e telhas quebradas, brinquedos de crianças desmontados ou partidos, chinelos arrebentados e bolas furadas. Ou objetos que ainda são utilizados, como ferramentas de pá, foice e facão, redes e varas de pescas, galões de gasolina, botas e botinas. Entre os objetos que são utilizados, estão as pedras-de-amolar facões e machados que remetem a tempos antigos. Essas pedras são objetos específicos encontrados fora do território da comunidade e trazidos para serem transformados em ferramentas de uso, utilizados durante longos períodos.

Alocada em um tronco na frente da casa, Seu Chico exibe a pedra-de-amolar que seu falecido sogro trouxe da cabeceira do rio da serra há muitos anos atrás. Outra pedrade-amolar encontrada em um suporte em frente a casa da família de Seu Frederico foi

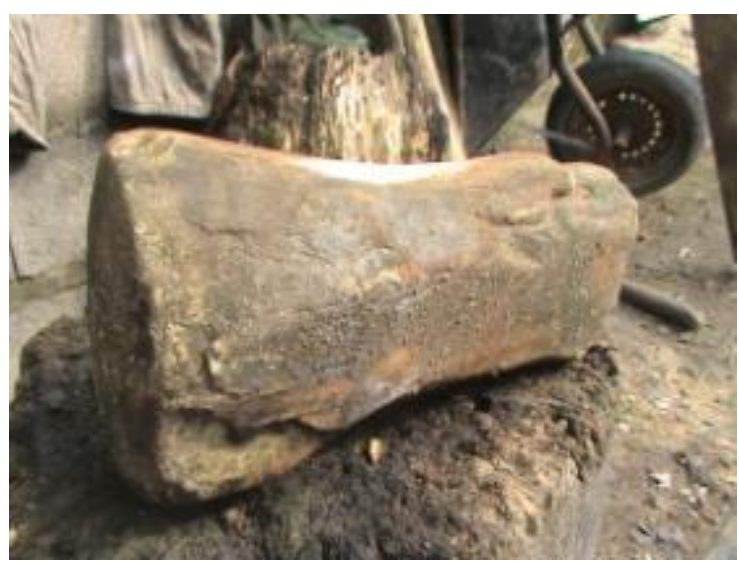

Figura 28: Pedra de amolar da cabeceira do rio da serra.

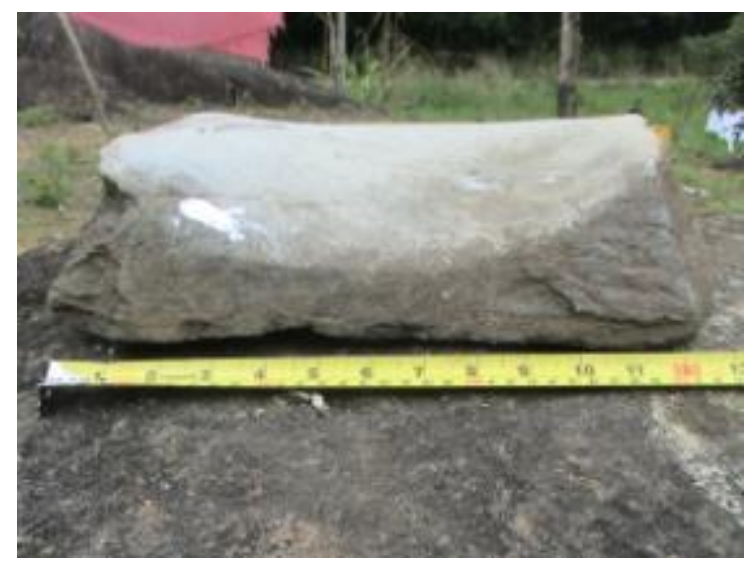

Figura 27: Pedra de amolar da llha da Casca. 
coletada pelo próprio, na companhia de Seu Chico, na Ilha da Casca, na entrada do Canal Ararapira. Essas pedras são usadas hoje em dia para amolar facas e facões. Segundo eles a pedra boa para amolar não pode ser muito mole. Ela tem que ser dura pra durar bastante tempo.

Já as atividades de corte e costura das mulheres são realizadas desde 2000 no barracão da associação construído em mutirão. Segundo Dona Irene, as mulheres sempre praticaram essa atividade, mas foi depois de 2000, com o auxílio do ITESP

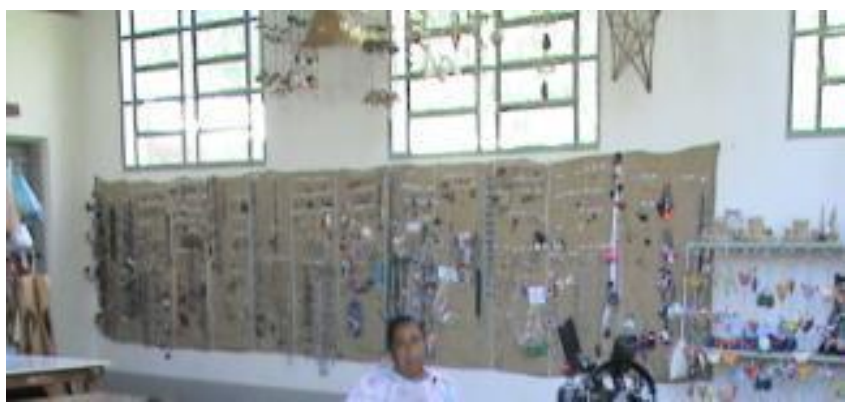

Figura 29: Lojinha comunitária. fornecendo curso de capacitação, que a comunidade adquiriu as máquinas para o serviço. Hoje, as mulheres produzem roupas e artesanatos que são vendidos na lojinha da comunidade frequentada pelos visitantes.

\subsubsection{0 artesanato.}

Os objetos do artesanato são trabalhados destacando a matéria-prima encontrada na região. São diferentes tipos de objetos confeccionados conforme a criatividade da artesã ou artesão, para atender a demanda dos visitantes da comunidade. Os brincos e colares, por exemplo, em sua maioria são feitos com diferentes tipos de sementes coletadas nas trilhas, no mangue ou próximo às casas. Algumas dessas sementes são conhecidas por nomes fornecidos pela comunidade, como Capiá para a Lágrima-denossa-senhora, Curuonha para o Olho-de-boi, o que demonstra a familiaridade com o material. Outras são coletadas apenas pelos homens, como o Olho-de-cabra, por ser encontradas em mata fechada, onde poucos frequentam e são lugares relacionados às

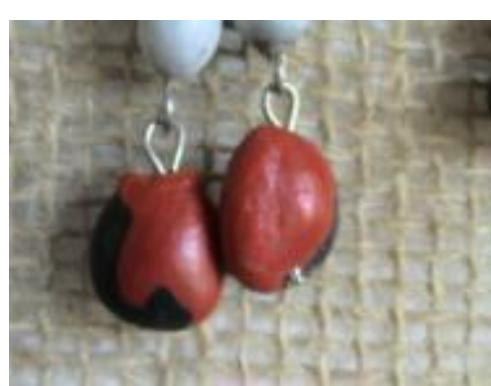

Figura 32: Olho-de-cabra.

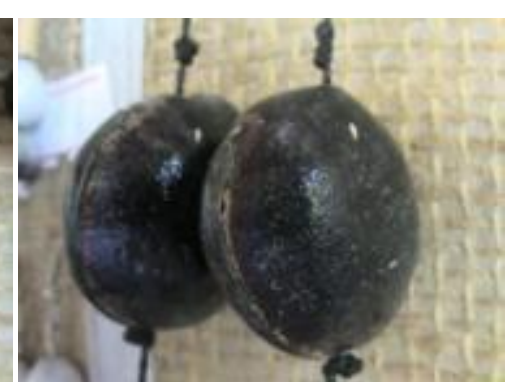

Figura 31: Curuonha.

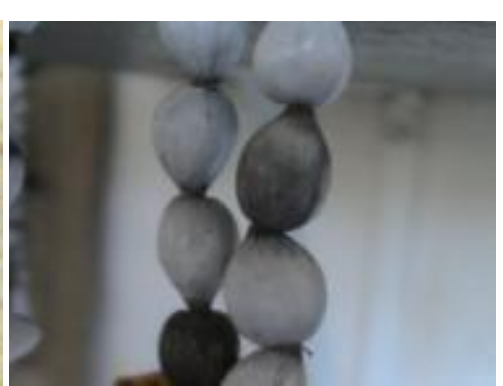

Figura 30: Capiá. 
antigas atividades masculinas de caça e extração de madeira.

Outros brincos e colares também são confeccionados com palha de ouro, casca de árvore ou da própria semente, casca de ostra e unha e dente de animal. Tem também as cortinas que misturam sementes com enfeites de fuxico e as almofadas de tecido preenchidas com palha de milho. Além de talheres, cadeiras e enfeites de porta feitos de madeiras da região. Entretanto, os artefatos mais tradicionalmente utilizados pelos Mandira são os cestos feitos de cipó

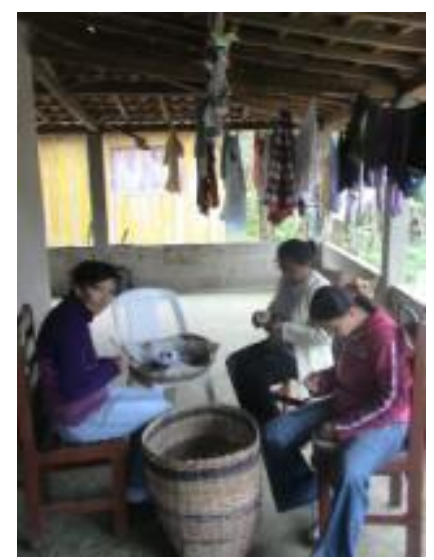

Figura 33: Mulheres fazendo fuxico. timbopeva e Imbé e as esteiras de Peri.

O imbé é um cipó menos largo que o Timbopeva. Para utilizá-lo, o artesão tira a casca e corta o cipó ao meio ou em quatro partes dependendo do tipo de cesto que quer confeccionar. Normalmente, é feito primeiro o fundo do cesto, de onde partem as tiras

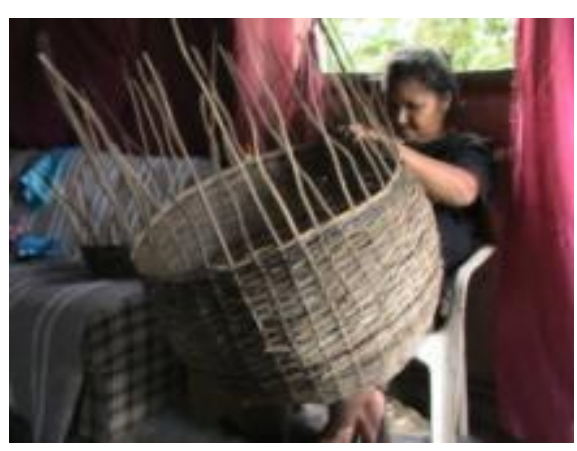

Figura 34: Dona Creusa verticais para serem transadas pelas tiras que partem na horizontal. Depois de feito o corpo do cesto, confecciona-se sua borda. A tampa é opcional. Geralmente são feitas nos cestos de Imbé por ser menos espesso é mais fácil de confeccionar base e tampa reta. Depois de pronto o cesto deve confeccionando cesto com Imbé.

ficar exposto ao sol até secar completamente para

O Timbopeva é um cipó largo e espesso, que não requer secar no sol. Com ele é confeccionado cestos arredondados, geralmente feitos com alças para carregar nas costas ou nos ombros, como bolsas e mochilas. Com o Timbopeva fazem o jacá.

O Peri (Cyperus giganteus) requer mais trabalho e conhecimento para utiliza-lo. Assim como o Imbé, ele precisa passar pelo processo de

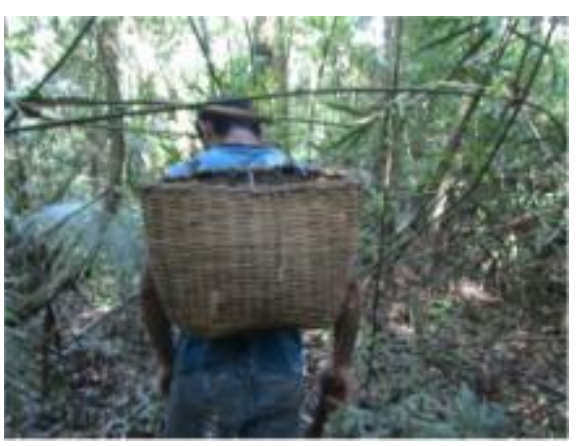

Figura 35: Jacá feito com cipó Timbupeva. secagem ao sol para não embolorar. Mesmo antes de fazer a esteira, o Peri tem que passar pelo tempo de secagem. Depois da esteira feita, se ainda não estiver completamente seco, deve voltar ao sol. 


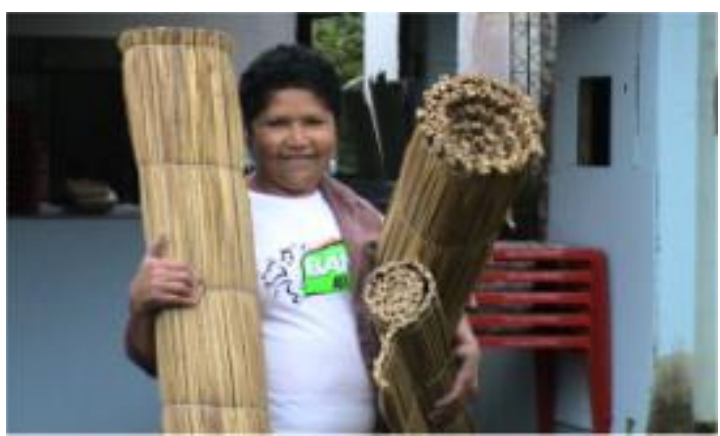

Figura 36: Dona Creusa com as esteiras de Peri.

O Peri é coletado em áreas alagadas e tem a época certa para ser coletado. Dona Creusa é a principal artesã entre os Mandira que trabalha com esse material. Segundo ela, a coleta deve ser na lua minguante, pois "quando se respeita a lua, o Peri seca e fica flexível e macio, bom para fazer esteiras", caso contrário o Peri fica seco e duro, podendo quebrar facilmente.

Os objetos artesanais são feitos o ano todo, mas a produção se intensifica nas épocas de festas. O Mandira é um povo muito festeiro e alegre. A fama da comunidade entre os vizinhos é de ser unida, hospitaleira e divertida. Em dias de festa o quilombo recebe pessoas de todos os bairros e cidades vizinhas, como Pariquera-Açu, Jacupiranga, Porto Cubatão, Itapitangui, Cananéia, Iguape, Juréia, São Paulo, Curitiba e outras procedências.

\subsubsection{As festas.}

São duas as principais festas patrocinadas pela comunidade: a tradicional festa do padroeiro da comunidade, a Festa do Santo Antônio, dia 13 de junho e a Festa da Ostra, dia 20 de novembro.

A Festa da Ostra é uma celebração realizada há cinco anos, como homenagem ao dia nacional da consciência negra. O principal objetivo é divulgar a culinária e os atrativos turísticos dos Mandira. Durante os três dias de festa são elaborados atrações com a temática da ostra durante o dia e shows de bandas de músicas tradicionais da região no período da noite. Na festa de 2008 tiveram apresentações de maculele e capoeira de grupos de jovens de Cananéia e da própria comunidade.

A culinária dos Mandira é uma grande referência tanto entre as comunidades quilombolas de todo o vale do Ribeira, como entre as próprias comunidades de Cananéia. Com pratos voltados a temática da ostra, são apresentados pasteis, tortas, risotos e farofa de ostra, além de porções de ostra grelhada e em natura. Para além da ostra a comunidade apresenta pratos com peixes típicos da região. 
Tradicionalmente a festa de Santo Antônio é a festa do padroeiro da comunidade, realizada dia 13 de junho. Dizem que essa festa acontece desde o tempo da fazenda. Todo ano a comunidade se mobiliza para organizar a festa. A festa começa a ser preparada um mês antes, mas na última semana os preparativos são intensos. Toda a comunidade é enfeitada com bandeirinhas triangulares, caixas de som com alto falantes, uma fogueira com mais de três metros de toras de lenha e um pau de sebo muito bem preparado para a festança. As prendas para o bingo chegam de todas as famílias e amigos mais próximos. As ostras, peixes e outros alimentos são preparados. Além de pintarem a quadra para o futebol de domingo e, principalmente, a igreja, para o tradicional terço cantado do início da noite de sábado.

Muito religiosa, Dona Irene conta que antigamente a festa era prioritariamente religiosa. Acontecia em torno do terço cantado. Seu Arnaldo, o capelão responsável pelo terço, lembra que "nesse tempo, as pessoas tinham muito amor, muita fé pelo trabalho que faziam. O terço era cantado com muito capricho, com muito respeito e por isso a festa ficava muito bonita".

O terço cantado no começo da noite, na véspera do dia de Santo Antônio, abria a celebração. Todos participavam do terço, com muita fé. Depois do terço, sempre tinha fandango. Durante toda a noite o povo permanecia em vigília tocando e cantando, celebrando o dia de Santo e dançando fandango. Os cantos de festa intermediavam os cantos de reza. Antes dos primeiros raios de sol, próximo às seis horas da manhã, soltavam foguetes para acordarem as pessoas que tinham ido dormir. Todos se juntavam novamente e tornavam a cantar o terço, ainda com mais fé, como encerramento. Depois faziam a despedida apreciando um chocolate bem quente e cada qual ia buscar seu descanso.

O problema, segundo Seu Arnaldo, "é que começou a juntar um pessoal que começava a bagunçar a noite. Traziam muita bebida para o baile e começou a ter muita briga e confusão. Então meu tio Jango, pra evitar essas coisas, parou com o fandango no tempo das festas. Ele não dava mais ordem pra fazer o fandango. E nesse tempo o pessoal era muito unido e sempre aceitava o que ele determinava. Então parou o fandango, não fizemos mais fandango".

Hoje, a festa acontece em horários e ambientes separados do terço. Segundo a justificativa, essa separação entre o canto de reza e o canto da festa foi por que a festa perdia seu sentido religioso por causa da bagunça e confusões que começaram acontecer. 


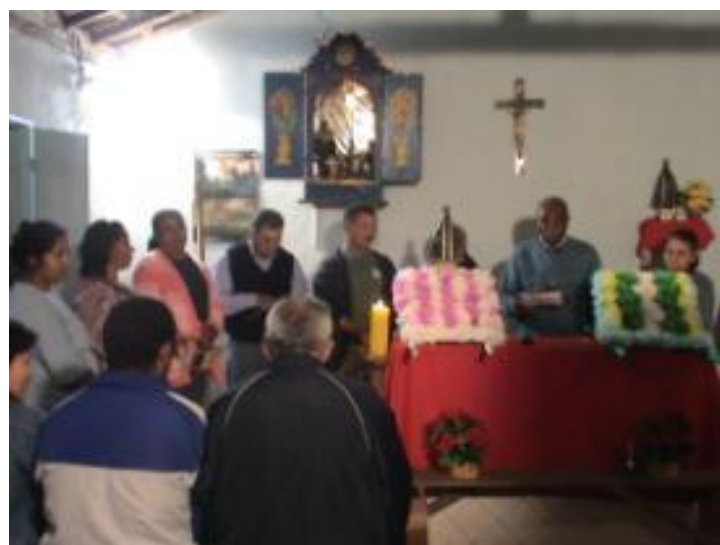

Figura 37: Terço cantado na igreja Mandira.
Ainda hoje, o terço é cantado no começo da noite, na véspera do dia de Santo Antônio, dia 12 de junho. Depois do terço tem a festa, mas com outro sentido do que o de antigamente. No lugar do fandango, a comunidade organiza uma quermesse, com brincadeiras de bingo e distribuição de prendas, vinho quente e quentão.

No dia 13, logo cedo, as pessoas acordam para dar início às celebrações do dia de Santo Antônio com o delicioso chocolate quente, mantendo a tradição. São enfeitados dois andores com flores e papeis coloridos em torno das imagens de Santo Antônio e Nossa Senhora Aparecida para a procissão. Ainda pela manhã, as imagens são carregadas pelos caminhos da comunidade, sempre com uma pessoa em cada braço do andor, como ato de glorificação dos Santos. Enquanto as imagens são carregadas para a capela, as pessoas caminham atrás entoando a reza da Santa Mãe. Na capela, o padre da paróquia reza uma missa.

Após a missa, tem início a festa do domingo, com futebol, comida e bebida. Há venda de churrasco e um torneio de futebol é organizado, com prêmios e troféus para os ganhadores. Deste modo, os Mandira utilizam das festas para promover a sociabilização com as comunidades do entorno. Muitas pessoas dos bairros de Cananéia e cidades vizinhas aparecem na festa.

Além das festas, o futebol vem a ser uma forma de estabelecer parcerias entre as comunidades de Cananéia e entorno. Os Mandira gostam muito de futebol. Nos fins-desemana sempre sociabilizam com as comunidades sendo convidados ou convidando para uma partida de futebol. As partidas acontecem normalmente aos domingos e são, por regra, seguidas de uma confraternização que inclui comidas e bebidas fornecidas pelos donos da casa. Assim, a sociabilização entre eles acontece através da busca por recursos para receber os convidados.

Como veremos a seguir os Mandira utilizavam dos Caminhos dos Antigos para irem nas comunidades vizinhas no intuito de vender alguns produtos ou simplesmente para se divertir e sociabilizar. 


\subsubsection{0 terço cantado.}

Entretanto, a principal forma de sociabilidade interna entre os próprios Mandira sempre foi pela fé. Pelo terço cantado os Mandira exercem seu espírito de fé ao mesmo tempo em que estabelecem alianças. Apesar de não ser mais o atrativo principal da festa do padroeiro, ele continua sendo uma das grandes tradições entre os Mandira. Além da festa de Santo Antônio ele acontece durante toda a quaresma e na casa das pessoas, sempre que alguém quer pagar alguma promessa ou pedir alguma bênção especial ${ }^{22}$.

No tempo da quaresma, o terço cantado adquiria o significado de penitência e todo ano tinha que ser feito em todos os dias santos: na quarta-feira de cinzas, depois sexta-feira dos passos, sexta-feira das dores e na semana santa começava de quarta-feira de trégua até sexta-feira da paixão. O responsável por dirigir o terço é o capelão. É ele o responsável por entoar o ritmo da melodia e manter elevada a vibração dos cânticos. $O$ capelão é sempre um homem mais velho, que herda o talento e sabedoria de cantar de algum antepassado direto, assim como as letras das canções e sua melodia e assume a responsabilidade de dirigir a parte espiritual da comunidade. $\mathrm{O}$ atual capelão do terço é Seu Arnaldo Mandira, de 62 anos, que mora em Porto Cubatão com a família, apesar de ter sido criado no Mandira.

Seu Arnaldo é filho de Geraldo Mandira e Maria Izídia Mandira. Seu avô paterno é João Vicente Mandira e seu avô materno é Joaquim Mateus, do vilarejo de Taquari. Para ele o terço cantado sempre existiu. Ele surgiu por necessidade, por que como o Mandira é longe da cidade, as pessoas não vão todos os domingos ás missas e os padres nunca apareciam no Mandira. Então, as pessoas praticam o terço cantado como forma de manifestar sua fé. Seu Arnaldo conta que sempre se interessou em ajudar a preparar e cantar o terço. Não lembra muito da época que seu avô rezava o terço, mas sabe dos acontecimentos pelas histórias que sua mãe lhe contava. Sabe que depois de João Vicente Mandira foi João Vicente Mandira Filho, o Jango, quem assumiu a direção do terço.

Como Jango era médium e curandeiro, adepto ao espiritismo, ele adequou algumas práticas do espiritismo ao terço cantado. Conta Seu Arnaldo que antigamente, quando não tinha igreja na comunidade, o terço era realizado na casa das pessoas. As

\footnotetext{
${ }^{22}$ Recentemente, o terço cantado do Mandira virou livro e CD titulado "Produção áudio visual do Terço Cantado - Preservação da memória e história desde a comunidade remanescente de quilombo Mandira, Cananéia, SP", com coordenadoria de Agane Fibra Tela, em parceria com a ONG Idesc e financiado pela Secretaria da Cultura do Estado de São Paulo, através do PROAC, 2010.
} 
salas eram arrumadas, com as esteiras de Peri e os travesseiros forravam o assoalho onde as pessoas podiam ajoelhar e rezar. $\mathrm{Na}$ outra parte da casa deixavam uma mesa com toalha branca, onde colocavam o oratório com as imagens dos Santos. Durante as rezas, Seu Jango incorporava seus guias para benzer as pessoas, benzer as águas e praticar a cura da comunidade.

Quando Seu Jango faleceu, a comunidade sofreu forte desestruturação por conta das proibições acompanhada do processo de segregação. Durante esse período, o terço cantado ficou meio abandonado. Até que Cristino Mandira assumiu a posição de capelão e líder da comunidade. Seu Arnaldo se lembra de Seu Cristino como "um homem de ideia e intenções muito boas. Muito consciente, ele entendia muito bem o processo das coisas. Uma pessoa de muita paciência, muito católico que deu continuidade no terço até o final da vida dele." E prossegue com as lembranças de como herdou a posição de capelão de seu tio-avô:

\begin{abstract}
"Por que no tempo do Cristino a gente aprendeu a rezar junto. Sempre era eu e ele. Quando tinha um terço nas casas ele me avisava e eu ajudava ele. Então agente começava a oração, ele começava cantar um verso e eu entoava. Ai depois eu continuava e ele prosseguia. Ai ficava que cada um cantava um verso. Eu acho que ficava mais bonito do que agora. Mas depois que ele morreu não teve um camarada que ajudasse pra mim. Eu dei continuidade no terço sozinho. Então hoje eu dirijo o terço lá."
\end{abstract}

Para Seu Arnaldo a função do capelão é principalmente começar as orações do terço. O capelão é quem sabe a sequência das orações. No começo da cerimônia existe uma ordem dos cânticos que o capelão deve seguir. Em todas as orações ele começa o cântico e em seguida os ajudantes prosseguem a entoada.

Entretanto, cada capelão dirige a cerimônia conforme seus conhecimentos e sua forma de praticar a fé. Assim como no tempo de Seu Jango existia durante a cerimônia do terço um momento de cura e benção, hoje em dia Seu Arnaldo sente a necessidade de reservar um momento na cerimônia durante o qual ele lê trechos da bíblia. Segundo ele “a bíblia faz parte de todo o tipo de oração.” E desta forma ele está pedindo proteção, pedindo ajuda, pedindo a benção e essa é a função do capelão durante a conduta do terço cantado nos Mandira. 
As rezas sempre foram as mesmas, com as mesmas letras e a mesma toada lenta, devagar, cansada. Junto com as músicas existe o oratório com as esculturas dos Santos, ambos feitos da madeira Canela-preta. As imagens sempre estiveram presentes nas cerimônias. Dizem que o oratório e outras duas das esculturas- uma de Santo Antônio e outra de Nossa Senhora Aparecida - têm mais de duzentos anos e foram feitas pelos escravos, na época da fazenda. Os sinais desse tempo eram visíveis na escultura de menos de vinte centímetros de altura e dez gramas de peso, que representa a imagem desgastada de um Santo Antônio negro, segurando uma criança também negra e portando uma capa escura. Sua expressão é serena e seu olho não demonstra a direção do olhar, o que representa, entre as esculturas africanas, a onipresença.

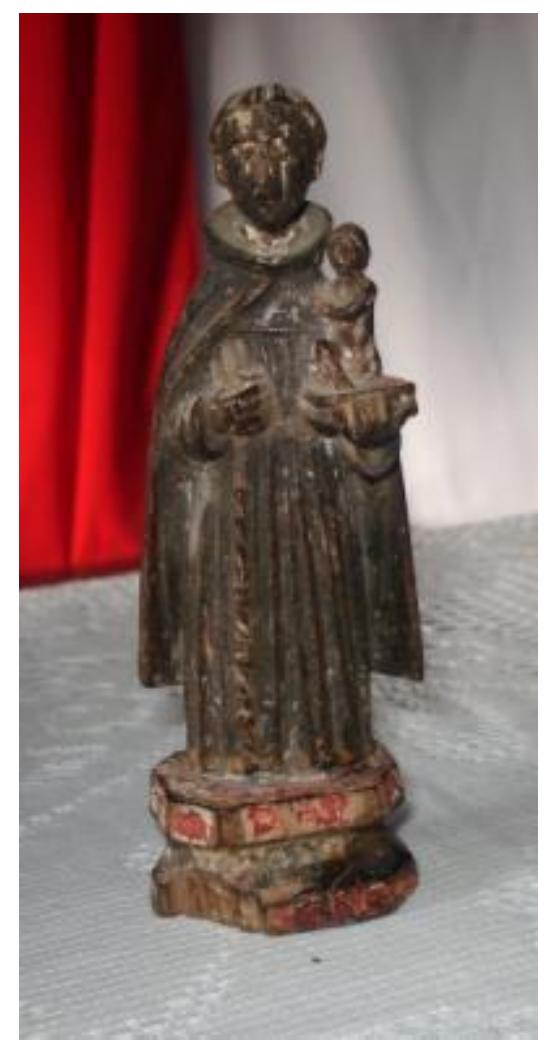

Figura 38: Imagem de Santo Antônio.

De qualquer forma, a imagem foi restaurada pelo padre da paróquia, padre Victor Hernández. Transferido para Cananéia após o falecimento do conhecido padre João Trinta, logo em contato com os Mandira o Padre Victor procurou agradar a comunidade revitalizando as peças. Para isso, ele pintou as peças na imagem tradicional do Santo Católico colocando ainda uma aureola dourada. O resultado não foi a gosto da

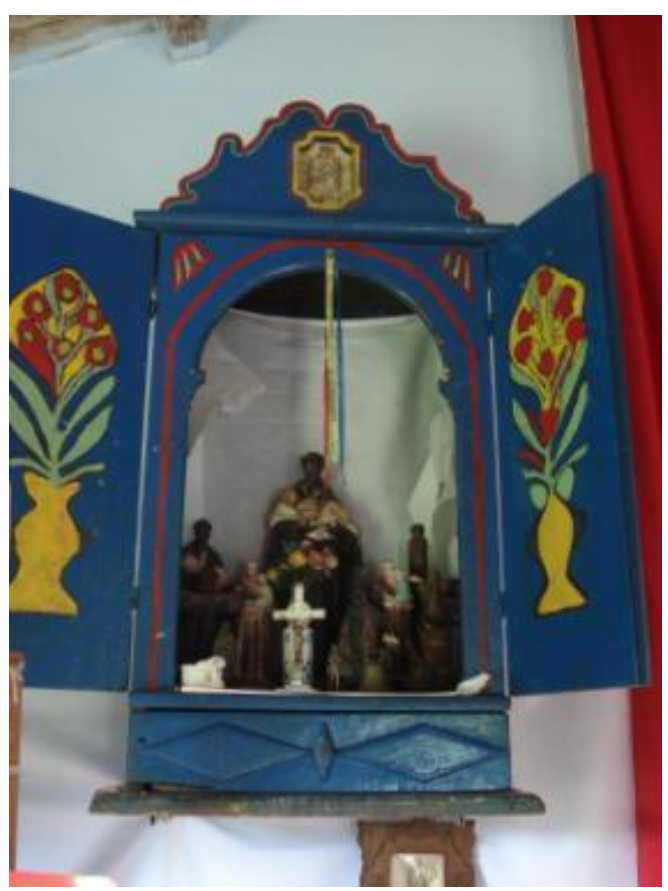
comunidade, que muito serena e asseverante de sua essência, espera o tempo voltar a revelar por detrás da imagem branca e frágil que a escultura aparenta ter, a verdadeira imagem antiga, feita de madeira com a cor forte da terra, que representa mais do que um santo, mas o Santo Padroeiro do quilombo do Mandira.

Figura 39: Oratório dos Mandira. 


\section{O TERRITÓRIO QUILOMBOLA MANDIRA.}

$\mathrm{Na}$ luta pelo reconhecimento histórico do direito de uso de toda a extensão de seu território, os Mandira permanecem recriando as formas de territorialidade herdadas pelos seus antepassados. O modo como essa territorialidade ocorre corresponde ao constante processo de formação e reformulação do território Mandira. No intuito de revelar a relação espaço-tempo que envolve esse processo, utilizamos a abordagem fenomenológica da Arqueologia da Paisagem como guia do estudo etnoarqueológico no quilombo Mandira. Com isso, almejamos entender o modo de apropriação dos elementos da paisagem, incluindo os sítios arqueológicos, que constituem a paisagem cultural desse território.

\subsection{FENOMENOLOGIA DA PAISAGEM: espaço, paisagem e lugares}

De uma forma geral, a abordagem fenomenológica objetiva apreender o modo como as pessoas experienciam e entendem o mundo. Fenomenologia envolve o entendimento e a descrição do pensamento, como eles são vividos pela subjetividade (TILLEY, 1994:12). Na arqueologia, a perspectiva fenomenológica tem sido aplicada principalmente nos estudos etnoarqueológicos contemporâneos sobre o uso do espaço (ZEDEÑO; 1997; 2009; INGOLD, 2000; CARROLL et al., 2004; WHITRIDGE, 2004; STEWARD et all., 2004).

Como uma vertente da Arqueologia da Paisagem, os estudos dos fundamentos fenomenológicos do espaço buscam superar a dicotomia entre sujeito e objeto, sem tornar-se refém de uma subjetividade que não apresenta uma unidade de análise (TILLEY, 1994). Para este desafio, a Arqueologia trabalha com o conceito de paisagem e suas derivações como um espaço-objeto, cuja vantagem está na capacidade de promover uma unidade analítica adequada para o diálogo entre diferentes perspectivas. A arqueologia da paisagem, contribuindo para o entendimento do modo como as pessoas interagem com os elementos do entorno nas variações do tempo, espaço, ecologia e contexto cognitivo, possibilita a superação da dicotomia entre uma 
perspectiva positivista e outra humanística (ANSCHUETZ et al., 2001). Para entender melhor como a perspectiva fenomenológica da paisagem se manifesta é interessante ver como essa polaridade científica foi construída.

A visão positivista da nova Arqueologia e Geografia dos anos 1960 apresenta a paisagem como um espaço generalista. As atividades, eventos e espaços são separados tanto conceitualmente como fisicamente uns dos outros. Suas relações são apresentadas de forma contingente, apenas como explicações específicas para medições de escalas geométricas ou pontos ilustrativos de modelos e formulações generalizadas. A paisagem é tratada como um espaço desabitado, atemporal. Visto como um palco, que pode ou não ser habitado pelo homem, mas que se apresenta neutro e quantificado, desprovido de qualquer estrutura de agência ou significado.

A oposição desta perspectiva positivista surge com a reteorização da geografia humana dos anos 1970 em diante e os debates da arqueologia pós-processual a partir dos anos 1980. Apoiados no estruturalismo, essas novas correntes teóricas consideram o espaço como um meio ao invés de palco da ação humana. A paisagem emana como manifestação simbólica e cognitiva, da dinâmica interação das pessoas com os elementos físicos do ambiente. É algo altamente simbólico não compreendendo mais do que uma representação subjetiva dos distintos mundos culturais.

No inter-fluxo destes dois caminhos, Ingold (1993:189) propõe o termo “dwelling perspective", pelo qual "paisagem é constituida enquanto um duradouro registro - e testemunho - de vidas e trabalhos de gerações passadas, que habitaram esse ambiente, e fazendo isso, deixaram seus vestígios". Assim, paisagem é o resultado da ação e percepção humana, no qual pessoas e meio ambiente são componentes constitutivos do mesmo mundo. A paisagem natural é conhecida e incorporada de significados relacionados através das experiências da coletividade.

Nesse sentido, a percepção do pesquisador não se dá no vazio, mas na experiência concreta do convívio. Para Tim Ingold (2000:189), da mesma forma que os moradores nativos formulam seus conhecimentos históricos pela atividade do convívio na paisagem codificada, a prática arqueológica também é uma forma de convívio. Por isso, "tanto ao arqueólogo quanto ao morador nativo, a paisagem conta - ou antes, éuma história”. O que diferencia são as regras e métodos de envolvimento empregados por cada uma das partes, por isso as narrativas históricas que ambos contam também são diferentes. 
Contudo, o conjunto das tarefas e ações empregadas ao longo do tempo (sejam atividades diárias ou eventos temporários), em suas mútuas ligações, é chamado por Ingold de taskscape. Esse termo implica em uma noção de temporalidade vinculada às interatividades de convívio social. Essa "temporalidade da taskscape”, por sua vez, envolve todos os elementos sensoriais percebidos, que não estão limitados aos homens, mas também aos seres animados e inanimados. Isso exige uma percepção ampliada da noção de interatividade, assim como a cultura material resultantes dessas ações. Projetar a temporalidade das relações para além das pessoas e animais do presente envolve pensar o comportamento em relação às pessoas e animais do passado, elementos perceptíveis como o mar, o vento, o movimento da maré, a presença ou ausência do sol, as fases da lua, enfim, todos os elementos ativos e significativos na interatividade social (INGOLD, 2000:194).

O entendimento do conceito de temporalidade da taskscape auxilia as pesquisas arqueológicas e etnoarqueológicas no campo da Arqueologia da Paisagem, pois amplia também a percepção da cultura material para além dos objetos e vestígios evidenciados nos sítios arqueológicos. Recentes trabalhos etnográficos e históricos entre os Numic, expostos por Carroll, Zedeño e Stoffle (2004) mostram como feições topográficas, como montanhas, cavernas e campos e recursos naturais, como rios e cachoeiras, são incorporados nas práticas ritualísticas desse grupo. Os autores demonstram como a interpretação destes dados combinando parâmetros geográficos, fenomenológicos e da cultura material conferem um padrão estrutural válido para determinar a configuração de lugares ritualísticos e suas posições em relação a outros lugares que não são usados para rituais (CARROLL et al, 2004).

Compreendida pela relação constante entre pessoas e os elementos físicos do meio ambiente, a paisagem é vista dialeticamente tanto como meio, quanto como resultado da ação presente e das ações no passado. O processo de atuação em um espaço, seja permanente ou por eventos realizados entre intervalos de tempo, envolve projeções e reconhecimentos de significados que codifica o ambiente, criando lugares significativos, com memórias e biografias. Tais lugares associados e memorizados remetem a noção de lugares corporificados (BROWN, 2004) humanizados e significativos (TILLEY, 1994; ZEDEÑO \& BOWSER, 2009; ANSCHUTZ et al. 2001).

Com a mesma ênfase nos lugares significativos, alguns arqueólogos examinam o sistema de assentamento e enfatizam a variabilidade contextual que cada lugar poderia apresentar em diferentes momentos do dia, do ano ou de períodos de vida. Em outras 
palavras, eles afirmam que o sentido dos lugares e as atividades neles realizadas são complexas e mutáveis, envolvidas materialmente com seqüências de decisões e disposições (ASHMORE, 2009:1176).

Ashmore (2009:15-30), ao analisar o sítio Quiriguá, na Guatemala, conhecido como assentamento dos povos Maia, observa que os lugares podem adquirir sucessivos significados de uso ao longo do tempo. A biografia dos lugares pode ser reescrita pela associação a novos mitos criados, pela modificação de seus elementos, pela associação e distribuição de novos elementos, por uma memória seletiva ou pelo distanciamento entre o lugar e seus usuários. Segundo o autor, a biografia dos lugares envolve a percepção seguida da ação de uso dos seus signatários, podendo ser manipulado por um indivíduo, por um fragmento social, por todo o grupo, ou até por mais de um grupo simultaneamente, criando um sentido de continuidade ou ressignificação.

Através dessas novas perspectivas teóricas que reconhecem a dialética estruturante das relações entre vetores sociais, os lugares adquirem agência, sendo estruturados e estruturantes das ações sociais. Por não serem estágios passivos, providos de signos e significados compartilhados, os sítios também podem influenciar as relações e mudanças sociais (ZEDEÑO \& BOWSER, 2009). Esses trabalhos exploram a concepção holística do lugar ou do conjunto de lugares enquanto paisagem que incorpora biografias ativas, podendo adquirir diferentes significados simultâneos (ASHMORE, 2009). Compreender as diferentes contextualizações da paisagem é entender a codificação cultural dos povos que ocupam esses lugares, para buscar compreender os elementos da inter-relação entre pessoas e ambiente físico como processo que leva a coerência cosmológica transmitida de geração à geração.

Assim, é importante notar que a paisagem é infinita aos olhos de quem vê. Nenhuma característica na paisagem é, por si só, uma fronteira. Ela só se torna uma fronteira, em relação às atividades das pessoas (ou elementos) para as quais ela é reconhecida ou vivida como tal (INGOLD, 2000:193).

Assim, para Tilley (op. cit.) as fronteiras territoriais são preferencialmente os protótipos naturais como rios, montanhas, rochas e o mar por serem apropriados simbolicamente, como significantes e delimitadores territoriais. Por outro lado, Zedeño (1997:71) aponta que os territórios freqüentemente são delimitados por zonas limítrofes (buffer zonas) geralmente usadas por mais de uma sociedade e coincidem com marcos geográficos maiores, rotas comerciais, áreas migratórias, ou lugares sagrados. Entretanto, pesquisas têm mostrado que na maioria das vezes, os limites dos desenhos 
fronteiriços apresentam de fato um registro da história de uso da terra por outro grupo particular, ou seja, sítios arqueológicos apropriados como marcos fronteiriços. De qualquer forma, as fronteiras dizem respeito a escolha de lugares e redes de sociabilização, que apontam para identificações e alteridades de grupos e indivíduos. Sendo assim, a partir do reconhecimento de fronteiras na paisagem estabelecem-se os territórios.

\subsection{TERRITÓRIO ENQUANTO OBJETO AGREGADO: Terra, território, territorialidade}

Segundo Zedeño (2008:210-211), a habilidade de dialogar com conceitos e modelos de largos e, algumas vezes, diferentes campos científicos e conhecimentos tradicionais, construindo a partir desses uma estrutura interpretativa sobre sociedades humanas, é uma rara característica da prática arqueológica que garante seu lugar nos estudos contemporâneos de território, de uso da terra e territorialidade.

Os territórios surgem então, como estruturantes da paisagem, delimitando a relação entre os elementos "de dentro" e os elementos "de fora", assim como entre o "nosso lugar" e os "outros lugares" (TILLEY, 1994:17). Entretanto, os territórios não são homogêneos, formados por fronteiras bem definidas. Essa visão derivada do pensamento da geografia moderna do ocidente, não se aplica aos territórios de sociedades não industrializadas (ZEDEÑO, 1997:70; 2008:211). Ao contrário, pretendemos demonstrar que território, assim como paisagem, para seu amplo entendimento deve ser analisado não como a forma de um espaço geográfico, mas como objeto de análise social (SANTOS,1994).

O território é formado pela operação da interatividade ampliada (taskscape) da sociedade. Trata-se de um recorte na paisagem, constituído por um único lugar ou uma composição de lugares, em termos das formas efetivas de ocupação e uso da terra. Os vestígios materiais, registros dessa interatividade ampliada, refletem as mudanças na paisagem empregadas pelos Homens, assim como os ajustes das estratégias de uso da terra em relação às mudanças ambientais. 
São muitos os sinônimos aplicados à palavra terra. De forma geral, terra pode ser entendida como um tipo de espaço natural, que se apresenta em diferentes tipos de escalas. Assim, chamamos costumeiramente de terra um terreno, um lugar desconhecido e inexplorado, ou o planeta Terra. Neste trabalho, adotamos o termo terra utilizado por Zedeño (1997) para pensar o processo de formação de um território. Desta forma, deve ser entendida como um termo que abarca a noção espacial de uma área conhecida habitualmente, com seus elementos incorporados, onde se encontram os recursos da natureza e os objetos da ação Humana.

Território, por sua vez, pode ser entendido como a manifestação material da territorialidade humana. Para Zedeño (1997:72), território, enquanto objeto de análise arqueológica que totaliza o espaço de pertencimento de uma sociedade, pode ser definido pela presença e combinação de três materiais elementares: I) Terra; II) Recursos naturais e III) Vestígios da ocupação Humana.

Através desses elementos, o território é visto como sendo um conjunto de objeto agregado, reunidos historicamente através de processos dinâmicos de interação sócioambiental, que direcionam para três fatores de dimensões essenciais do território:

I) A gama de interações do homem com a terra;

II) As escalas espaciais dessas interações; e

III) O processo histórico do uso da terra e dos recursos naturais.

Com esse modelo a pesquisadora almeja vislumbrar as trajetórias sociais de estabelecimento, manutenção e transformação pelas quais passa a história de formação dos territórios, revelando os processos de continuidades, mudanças e rupturas das populações que habitam e habitaram esses territórios. A variabilidade dos conjuntos de materiais arqueológicos e sua disposição espacial, portanto, está relacionada com as atividades levadas a cabo nestes locais, revelando a disposição das áreas de atividades, a funcionalidade dos sítios, a dinâmica dos processos de deposição dos materiais (SCHIFFER, 1972; BINFORD, 1983b, 1983c, 1983d, 1983e) e, ao mesmo tempo, revela o modo como os materiais deixados por um grupo podem ter sido apropriados como objeto de uso ou objeto simbólico - pelos grupos herdeiros dessa paisagem (HODDER, 1992; ZEDEÑO, 1997; 2008; 2009; PANJA, 2004; STEWARD et al., 2004; CARROLL et al., 20004; ASHMORE, 2009). 
Sendo assim, a história de vida do território é o resultado da combinação da história natural da região e de seus recursos, com as diferentes histórias sociais do uso da terra e de seus recursos. O exame desses processos através dos vestígios deixados na paisagem permite ao arqueólogo identificar não apenas territórios em geral, mas também, específicas formas e estratégias de territorialidade. A partir dessa constatação, Zedeño (1997:86-95) elabora um modelo teórico - apropriando-se do "diagrama de fluxo" de Schiffer (1987:13) - das possíveis etapas e sub-etapas do ciclo de vida de um território, que visa subsidiar as análises sobre o processo de formação territorial em diferentes contextos históricos e culturais.

Para além da história de vida do território, nosso trabalho etnoarqueológico no quilombo Mandira pretende explorar a territorialidade dos Mandira para pensar como se constituiu o processo de formação de seu território. Para isso, partimos dessa perspectiva de território enquanto unidade espacial que abriga o escopo dos elementos que envolvem o comportamento humano em sua interação com a paisagem natural e arqueológica, buscando traços específicos do significado sócio-cultural destas duas dimensões da paisagem.

Estudos mostram que desde o passado remoto toda a região que hoje é o município de Cananéia, onde está localizado o território Mandira, foi ocupada por povos bastante distintos. Várias identidades e histórias se sucederam ou coexistiram neste território, formando um palimpsesto de ocupações, re-ocupações e abandonos territoriais que precisam ser estudados. Nosso objetivo, neste trabalho, é contribuir na recuperação da história dos Mandira em seu território.

Procurar explorar o modo como a população quilombola do Mandira reage à diversidade de vestígios arqueológicos presentes em seu ambiente habitado, implica diretamente no processo de formação do seu Território. Entender, a trajetória de formação territorial é crucial em contextos de pesquisa arqueológica em comunidades tradicionais (por exemplo, quilombolas, indígenas, caiçaras, caboclos), pois tal conhecimento é, muitas vezes, fundamental e estratégico para os direitos territoriais e a manutenção da autodeterminação dessas populações (FUNARI, 2008; SILVA, 2009).

“Em contextos territoriais ocupados por populações indígenas e quilombolas, a arqueologia pode desvendar as múltiplas ocupações e modos de vida que ali se sucederam e a mudança dos ambientes com o tempo. Neste sentido "a relação simbólica desses grupos com seus ambientes encontra, na pesquisa arqueológica, 
contrapontos e recursos para a sua re-interpretação da comunidade como entidade histórica" (FUNARI, 2008:3-4 apud SILVA, 2009:212).

\subsection{As fronteiras.}

$\mathrm{Na}$ história de formação do território Mandira os dados apontam para um acontecimento curioso. Como vimos, existiu uma primeira divisão das terras originais da Fazenda Mandira ocasionada pelas brigas de João com seu irmão Antônio. Como ponto delimitador entre as duas partes de terra, o Salto do rio Mandira tornou-se um lugar significativo presente nas narrativas históricas.

Na primeira certidão arquivada no

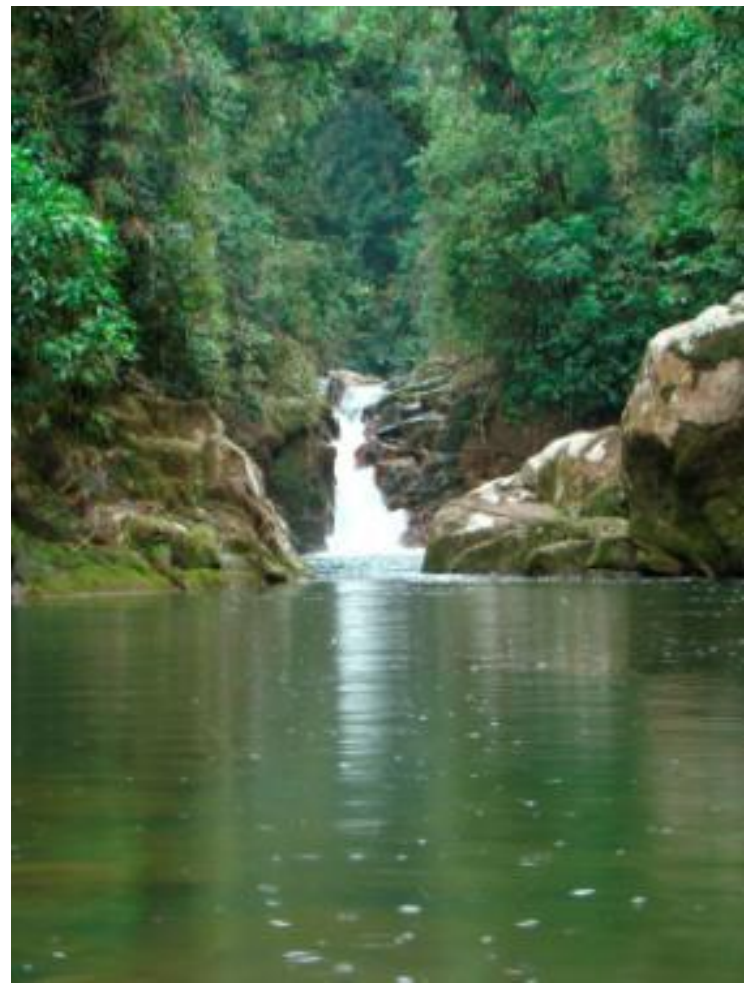

Figura 40: Salto do Mandira. ex-Registro de Imobiliário da extinta Comarca de Cananéia, referente às terras da fazenda Mandira, o salto também é apontado como um dos pontos limítrofes das terras. Denominado sítio Mandira, o documento do dia 14 de setembro de 1912 em nome de João Vicente Mandira (ver Certidão reproduzido em imagem no Anexo 2) apresenta o imóvel, situado no Rio das Minas, Distrito de Paz de Cananéia, dentro das seguintes confrontações: "Para cima com terras de Anna Jacintha Peniche; para baixo com terrenos do "Boacica"; e fundos com terras do Salto. Benfeitorias existentes: casas de moradia, regod'água, cafeeiros, arvoredos de espinhos, bananeiras, mandiocal. "23

Percebe-se que, mesmo sendo uma descrição registrada em documento oficial, cujo intuito é definir legalmente os limites e extensão do território, os três marcos fronteiriços citados não apresentam uma escala cartográfica homogênea e apenas um deles pode ser considerado um ponto de referência para a demarcação do território: o

\footnotetext{
${ }^{23}$ Certidão do sítio denominado Mandira, do Livro de Registro Facultativo de Terras e Domínio do ExRegistro Imobiliário da extinta Comarca de Cananéia, atualmente sob o arquivo e guarda do Ofícial Registro de Imóveis, Titulos e Documentos, Civil de Pessoa Jurídica e Civil das Pessoas Naturais e de Interdições e Tutelas da sede Comarca de Cananéia. - Estado de São Paulo. 14 de setembro de 1912: página única (ver imagem no Anexo 2).
} 
Salto do rio Mandira. As terras de Anna Jacintha Peniche a oeste não apresentam nenhum marcador de fronteira bem definido, e a leste, os terrenos do Boacica, também não é exatamente uma marcação precisa. $\mathrm{O}$ fato de o documento pretender descrever $\mathrm{o}$ sítio Mandira com limites bem definidos demonstra o quanto João Mandira estava preocupado com a extensão e os limites do território, desde antes de 1912. Pressupõe-se que ele buscava os direitos de posse sobre essas terras, concedido pelo registro escrito, sobrepondo o direito de pertencimento formado pelo dinâmico processo de uso.

Neste sentido, segundo os relatos orais indicam, João apresentava os limites de baixo e de cima das terras com a pretensão de salvaguardar a porção de terras do Mandira que estava sob ameaça do Coronel Cabral, alem de criar oposição com a porção de terras além do Salto. Provavelmente, em decorrência dos fatores geográficos, como estar mais longe do mar, não ter acesso direto ao mangue e ter a maior porção de terra em declive agudo, as terras além do Salto não apresentavam grandes interesses. Por outro lado, João procurava os meios de restringir o uso das terras de baixo do salto a seus descendentes diretos. Isso leva a crer que as principais áreas de uso se concentravam na porção sul do território e que Antônio Mandira e seus descendentes também utilizavam essas áreas, inclusive para as atividades diárias, podendo vir a reivindicá-las por direito.

Fato é que João Vicente Mandira fez questão de registrar os limites e extensão do território, forjando assim um território denominado Mandira, em oposição a seu irmão Antônio, apesar deste carregar o mesmo sobrenome. Ao acionar a palavra escrita, João Vicente Mandira não só legitimou, como também perpetuou o acesso de seus descendentes ao seu universo particular das terras ao sul do Salto. O território Mandira foi definido então tendo o salto como marco fronteiriço, em oposição a seu parente Antônio Vicente Mandira, que também ocupava e explorava a mesma porção de terra.

Deste modo, não nos surpreende que, atualmente, quando questionados sobre os limites de seu território, os Mandira apresentem os mesmos marcos forjados na primeira Certidão Oficial de Registro de Imóveis do sítio Mandira, em nome de João Vicente Mandira. Assim, o Relatório Técnico-científico do ITESP delimita apenas a percepção territorial herdada de João Vicente Mandira, ou seja, metade de toda a área da fazenda originalmente doada a Francisco Vicente Mandira - tendo o salto como o marco divisor das terras: 
"João Vicente Mandira estabeleceu-se na área situada ao sul do Salto do rio Mandira, delimitada pelo rio Acaraú, a oeste, e pelo rio Cambupuçava e a Serra da Boacica, a leste, até o encontro com o Mar de Dentro, pela frente" (TURATTI, 2002:27).

Cada marco descrito acima faz parte da representação histórica transmitida por João Vicente Mandira, que orientou as relações sociais de seus descendentes. Comumente, as fronteiras são dinâmicas, sendo constantemente negociadas e justificadas pelas atividades de uso e políticas de interesses, que acionam as atualizações destas representações simbólicas. Atualmente, com os processos de retomada das histórias de seus antepassados, os Mandira reconhecem a porção de terra a cima do salto como parte de seu território. Como veremos, essa região abriga uma das trilhas mais antigas, utilizadas pelos Mandira para visitar os parentes e vender peixes no município vizinho. Esses lugares de montanhas guardam também algumas antigas áreas de moradia e muitas histórias das caças de Antônio Mandira.

Entre os Mandira, o ato de caçar dentro do território contribuiu para a manutenção e preservação dos limites do território. Os locais de caça comumente utilizadas sempre foram afastados das áreas de moradia, por isso, não raramente, pessoas de fora também fazem uso velado desses lugares. Entretanto, eles não se configuram enquanto locais compartilhados com outros grupos regionais. Pela constante disputa de terras os limites e uso do território sempre foi muito preservado pelos Mandira. Os locais de caça compartilhados com outros grupos são fora dos limites territoriais do Mandira. Do mesmo modo ocorre com a pesca que pode ser feita nos inúmeros rios e riachos existentes no território ou em regiões distantes, em outros territórios ou em locais coletivos de rios e mares.

Contudo, durante nossas pesquisas, observamos que o território dos Mandira configura-se com os seguintes marcos fronteiriços: A leste, delimitado pela Serra da Boacica, a oeste, pelo rio Acaraú, a norte, pelo divisor da Serra do Mandira, onde nasce o rio e se estende até o encontro com o Mar-de-Dentro, no local denominado Barra do Rio.

A toponímia de alguns desses lugares confirma a função fronteiriça que eles exercem na paisagem. A Barra do Rio, por exemplo, é onde o rio Mandira e o rio Boacica encontram o Mar-de-dentro. O Mar-de-dentro, também conhecido como Mar 
de Itapitangui ou Cubatão ${ }^{24}$, separa a porção territorial do município da Ilha de Cananéia. Entre a terra firme e a Barra do Rio se estende uma longa faixa de paisagem intermitente, variando entre mangue e espelho d'água, fato geográfico que enriquece a beleza da cena pela sucessiva transformação diária da paisagem, imprimida pelo movimento da maré.

Nesta área está localizado a Reserva Extrativista (RESEX) do Mandira. Trata-se de uma importante porção do território, muito utilizado nas atividades de pesca e extração de ostra. Assim, a Barra do Rio é o marco limite referencial, pois formula a hidrografia do Território, incluindo toda a extensa porção da paisagem alagada, além de toda a área banhada pelo serpenteado do rio, que leva o nome da comunidade.

A hidrografia do território Mandira é um espaço formado por lugares de extrema beleza e magia. Procurando romper com a posição de afastamento da ciência positivista, vamos entrar nesse espaço pela cadência das águas, até atingir as trilhas nos morros, buscando entender o sentido dos lugares significativos na formação da paisagem cultural do Território Mandira.

\subsection{Portos, mangues e canais como lugares culturais.}

Comecemos então pelo Mar-de-dentro, um ambiente ainda muito utilizado no deslocamento, visto como passagem para entrar e sair. É o lugar de acesso entre o mundo de dentro e o de fora. Por ele, os Mandira travam viagens ao mundo de fora, normalmente para comercializar produtos em Cananéia ou Iguape e, antigamente, também usado para visitar os parentes.

Pelo Mar-de-Dentro o território Mandira é acessado, entrando pela Barra do Rio. A partir da Barra do Rio, existem dois caminhos mais comumente usados

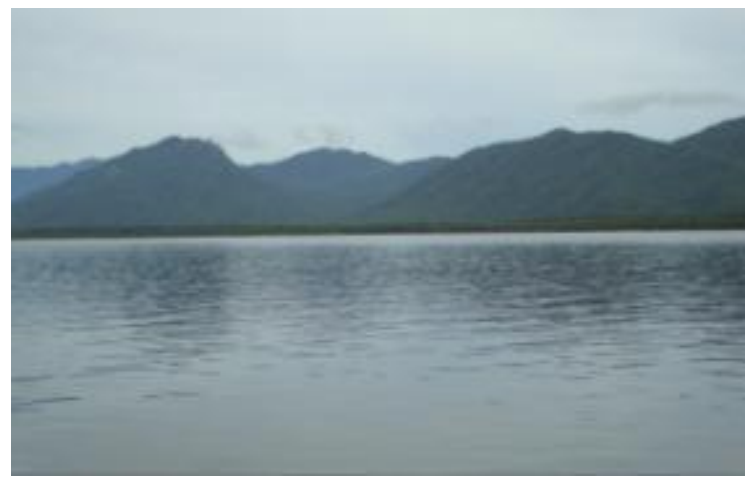

Figura 41: Vista do território Mandira pela Barra do rio.

\footnotetext{
${ }^{24}$ No livro de Paulino de Almeida, "Memórias de Cananéia" Vol. I. Coleção da Revista de História. São Paulo - Brasil. 1963, a porção do Mar-de-Dentro onde se encontra a Barra do Mandira é denominada de Mar de Itapitangui. Já no estudo de Benedito Calixto (1908) encontramos o Mar-de-Dentro sendo denominado pelos indígenas como Parana Mirim.
} 
para penetrar nas águas do território Mandira: ou pelo rio Mandira ou pelo rio Boacica. Por esses dois rios é possível transitar de canoa e barco por toda a área hidrográfica do território, acessando outros lugares de atividades específicas de pesca e coleta.

Todo esse espaço é denominado pelos Mandira de MARÉ. É um espaço onde o deslocamento e usos diários fazem surgir diferentes lugares significativos como portos, mangues, poços ou entrepostos de canais e rios onde se pesca, armam o juquiá, o covo e lançam as redes de pesca, coletam os fardos de Peri, capturam caranguejos, praticam a extração de ostras, montam e conservam os viveiros.

Os locais de instalação dos viveiros de ostras é, atualmente, uma das principais áreas de atividade freqüentadas pelos Mandira. Nos suaves meandros do rio Boacica, nos locais onde as águas não são profundas e correm suavemente, são construídos os viveiros para o cultivo das ostras (Crassostrea brasiliana) (ver indicação no Mapa Atual no Anexo 1). Os viveiros são montados com madeiras escolhidas, como Araça

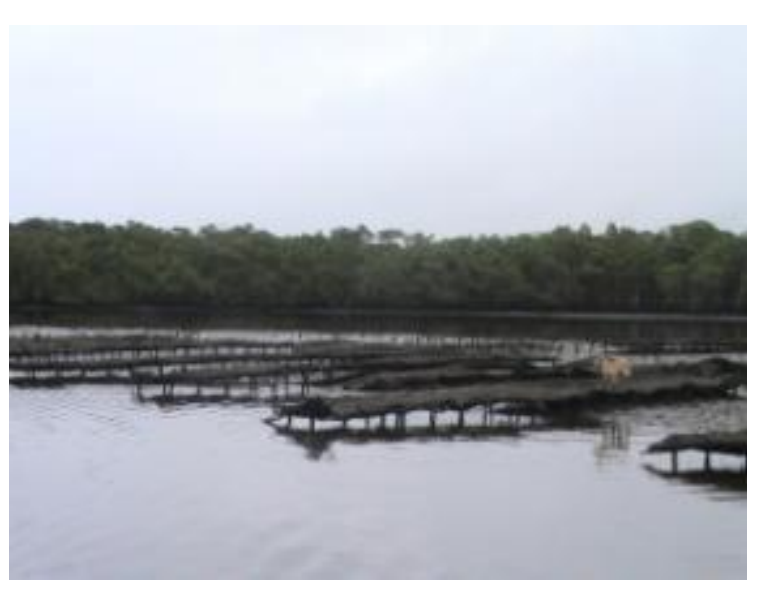

Figura 43: Viveiros de ostras.

(Psidium cattleianum), Guariroba (Syagrus oleracea), Pindaúva (Duguetio marcgraviana Mart), Pixirica (Miconia hyemalis), para conservar a estrutura no ambiente de forte ação da maré. A principal ameaça à essas madeiras nesse ambiente é o buzano (Teredo sp.), um verme que come madeira no mangue.

Os viveiros são montados com os esteios dessas madeiras enterrados no lodo do rio, formando três fileiras paralelas com pouco menos de um metro de distância uma da outra. Outros troncos finos são deitados e amarrados horizontalmente, interligando a fileira dos esteios paralelos. Por fim, são deitados mais troncos finos, emendados uns nos outros, formando três ou quatro colunas paralelas, em cima da estrutura. Nestes últimos troncos é amarrada a tela do viveiro, onde se coloca as ostras em cima e se tampa com outra tela do mesmo tamanho. A tela e as amarras são feitas com um arame encapado com plástico

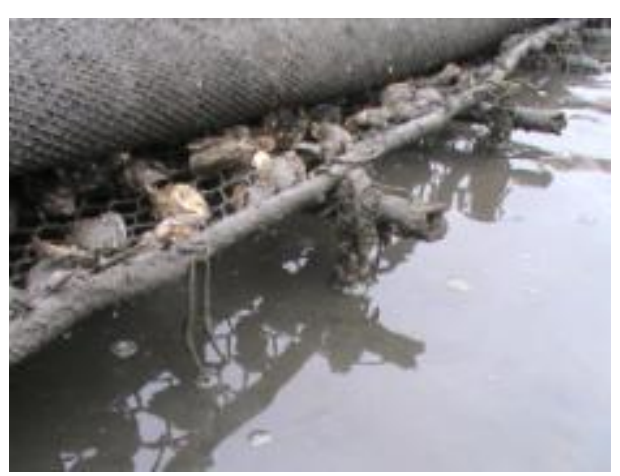

Figura 42: Detalhe dos materiais de confecção dos viveiros. 


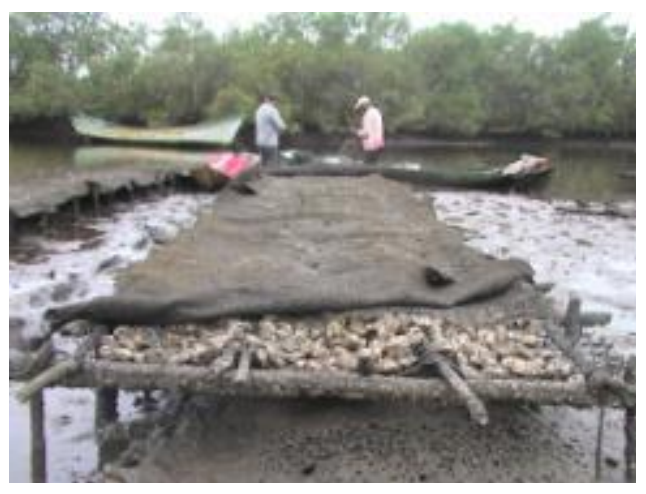

Figura 45: Viveiro de ostra.

grosso, mas antigamente poderia ser usado o Imbé.

Toda a estrutura retangular possui aproximadamente 10 X 1,5 metros de extensão. Segundo Seu Chico, essa estrutura feita de Guariroba, desde que mantenha os devidos reparos, que são basicamente repor os esteios atingidos pelo buzano, pode durar até dois anos sofrendo os impactos da maré. Depois do período de vida útil do viveiro, as telas de arame e plástico são reaproveitadas, mas os esteios são abandonados. No mesmo lugar é feito outro viveiro seguindo o mesmo modelo. Aos poucos, o lodo concentrado e o material abandonado formam montes de sedimentos assoreados, formando contextos específicos dessa ação humana na paisagem.

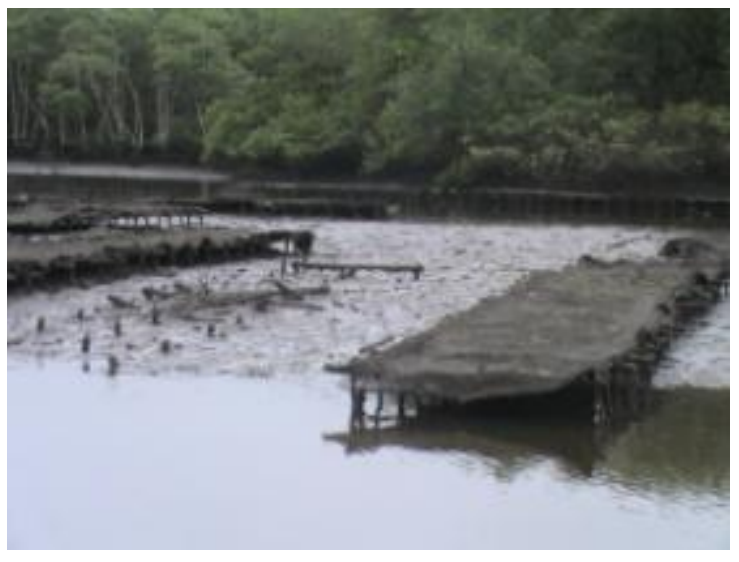

Figura 46: Viveiro e esteios dos antigos viveiros abandonados no lodo.

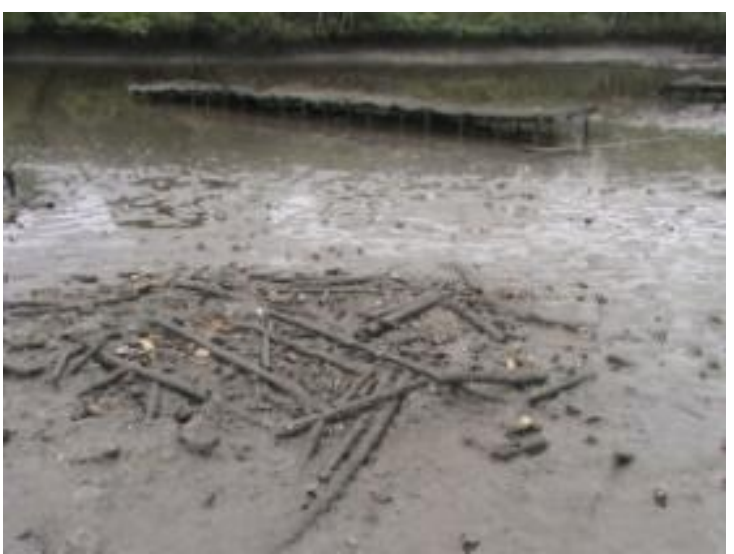

Figura 44: Detalhe da aglomeração dos esteios dos antigos viveiros abandonados no lodo.

Entretanto, os vestígios da ação humana sofrem constantes transformações nesses ecossistemas dinâmicos, com paisagens diariamente interrompidas. Somente uma ocupação intensa, com seguidas atividades repetidas ao longo de centenas de anos deixaria essas marcas duradouras na paisagem.

Um exemplo do dinamismo desse ambiente é lembrado pelos moradores mais antigos do Mandira. Seu Rubens e Dona Saturnina contam que no tempo em que a extração de caixeta era praticada para o sustento da comunidade, existia um canal que ligava o rio Mandira com o rio das Minas. Por esse canal as caixetas coletadas no rio das Minas eram levadas ao local de praia no rio Mandira, ao lado do canal (ver local sinalizado no "Mapa Histórico: Década de 1960” no Anexo 1). Nessa praia os troncos 


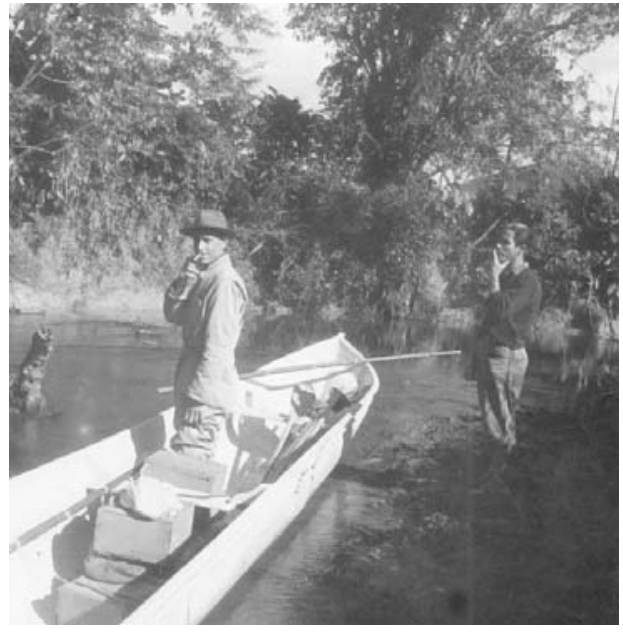

Figura 47: Aspecto do Rio das Minas em 1956 (Acervo IO/USP).

de caixeta eram vendidos ao atravessador, que os levava de lancha para serem revendidos em Cananéia ou em outras cidades. Eles lembram que antigamente não existia rua, "as ruas que tinham era só canoa, os rios e mais nada. Todos moravam na beira dos rios" e por eles se deslocavam. Por isso, os canais dos rios mantinham-se limpos e bem conservados. Quando os Mandira deixaram de trabalhar com a caixeta, em seguida foram segregados no extremo leste do território e as estradas abertas, muitos canais dos rios foram abandonados. O processo de deposição de sedimentos, troncos e galhos fez com que crescesse vegetação nos caminhos e canais. Com isso, passagens como esta entre o rio Mandira e o rio das Minas fechou em menos de trinta anos. Hoje, o caminho dos Mandira para o rio das Minas de canoa ficou bem mais longo.

Próximo a esse antigo canal, do lado do rio Mandira existe um perisal, onde alguns moradores visitam de tempos em tempos para

coletar Peri. O Peri é uma planta palustre da Figura 49: Perisal no rio Mandira. família das ciperaceas. Seu caule é longo e produz uma fibra semelhante ao linho, por isso é boa matéria-prima para a fabricação de esteiras. Típica de lugares encharcados e espelhos d'água, no Mandira existem poucos

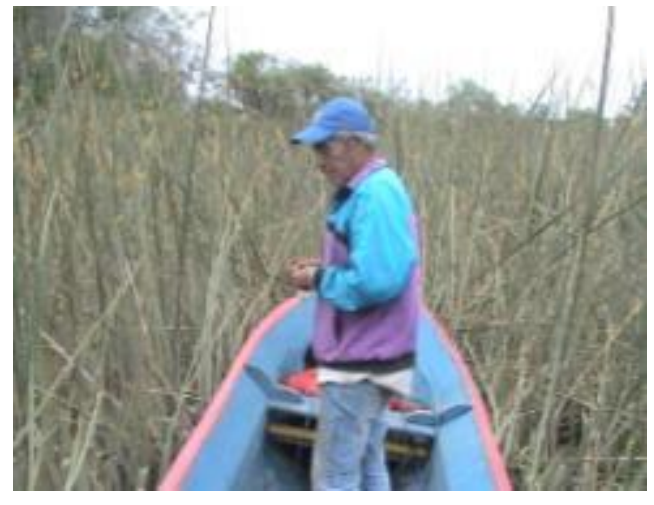

Figura 48: Seu Jango na coleta de Peri.

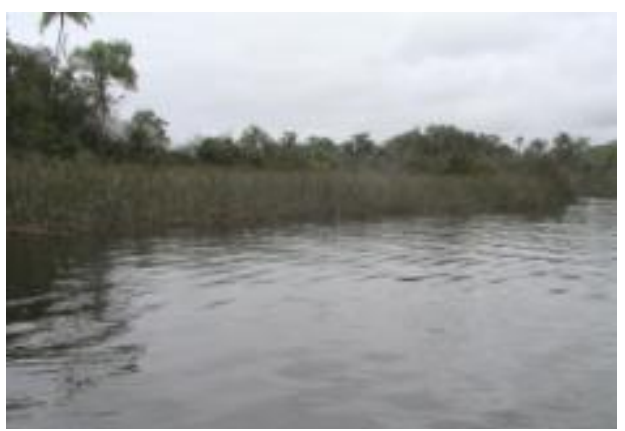
perisais, que são encontrados principalmente no rio Mandira (ver mapas no Anexo 1). Os principais perisais estão localizados nas mediações do território, no rio das Minas, na Barra do Caratuva, e mais afastado, no rio Taquari.

Dona Creusa e seu marido Jango coletam o peri durante a maré baixa da lua certa, cortando o caule bem rente a terra para 
aproveitar o maior tamanho. A planta tem que ser coletada ainda verde, para quando secar sua fibra ficar flexível, caso contrário o peri fica duro e quebradiço. Depois da coleta, o peri é amarrado em fardos para o melhor tranporte e acomodação na canoa. Transportado para a área de moradia, os peris são expostos ao sol para secar e não ter perigo de embolorar (como já abordado).

A presença das mulheres na Maré é menos freqüente que a dos homens. Geralmente, são as mulheres mais velhas que vão à Maré, aquelas que não precisam mais cuidar das crianças. Normalmente, elas vão para coletar algum material ou para coletar ostra e trabalhar nos viveiros, mas sempre acompanhadas de alguma figura masculina da família.

Como já abordado, a companhia de um homem é necessária, pois remar a canoa é tarefa pesada e quem exerce é o homem. Por causa disso, a pesca de rede sempre foi uma prática dos homens. As mulheres pescam de linha com anzol. Nos poços e canais da Barra do Mandira a pesca é feita pelos homens. Normalmente, a pesca só das mulheres é uma pesca de diversão, para pegar lambari no rio Mandira.

Assim, a paisagem da porção hidrográfica do território Mandira é formada por estas atividades de trabalhos e passagens diárias, onde as marcas da intervenção humana estão presentes também pelos objetos portáteis: como as unidades artificiais de pesca autônoma, conduzida pelos pescadores artesanais, e outros vestígios ligados ao cultivo das ostras, como os sacos carregados

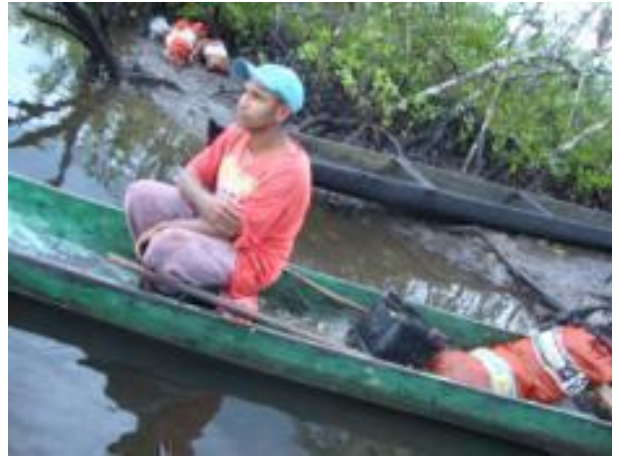

Figura 50: Inácio e os sacos de ostras no mangue e nas canoas. de ostras e jogados na entrada dos mangues esperando para serem transportados de barcos à Cananéia.

Além desses sinais resultado de ações cotidianas do presente, existem outros vestígios da intervenção humana ao longo de toda a área denominada Barra do Rio. São troncos grossos e compridos de uma madeira dura e resistente, que estão enterrados nas entradas dos mangues. Essas estruturas de madeira não remetem a fatos da memória recente dos moradores do Mandira. Eles também sabem que não são elementos originários do mangue, mas foram introduzidos de alguma forma nessa paisagem. Voltaremos a analisar esses vestígios mais a diante. 
Outros objetos portáteis e semiportáteis referente às atividades diárias dos Mandira nessa paisagem são encontrados nos

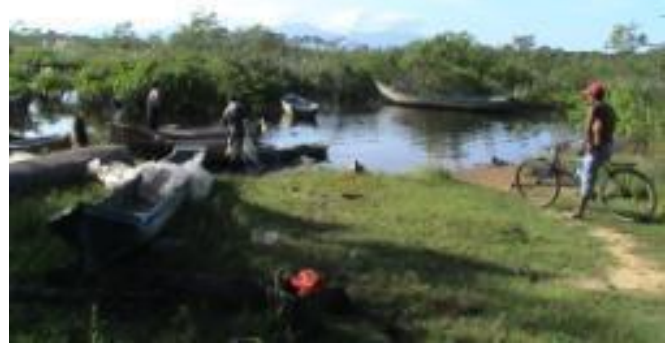

Figura 51: Porto Boacica. portos, como: canoas, barcos, remos e garrafas de plásticos com gasolina; cordas, redes de linha e redes de ticum ou tucumã (Astrocaryum vulgare Mart); os galões de plástico transformados em cestos e os cestos de Timbopeva; muitas estacas de madeira para amarrar canoa e algumas para confeccionar os viveiros; baldes, sacos de batata, foices e facões para pegar as ostras; botas para entrar no mangue, algumas cascas de ostras jogadas e outros artefatos.

Em meio a estes materiais encontramos no Porto do Boacica, também conhecido como Porto da Maré, uma rocha metassedimentar, com marcas de uso. A rocha apresenta uma concavidade esférica no centro artificialmente formatada, ainda hoje usada como base para a fixação de estacas de madeira para amarrar canoa.

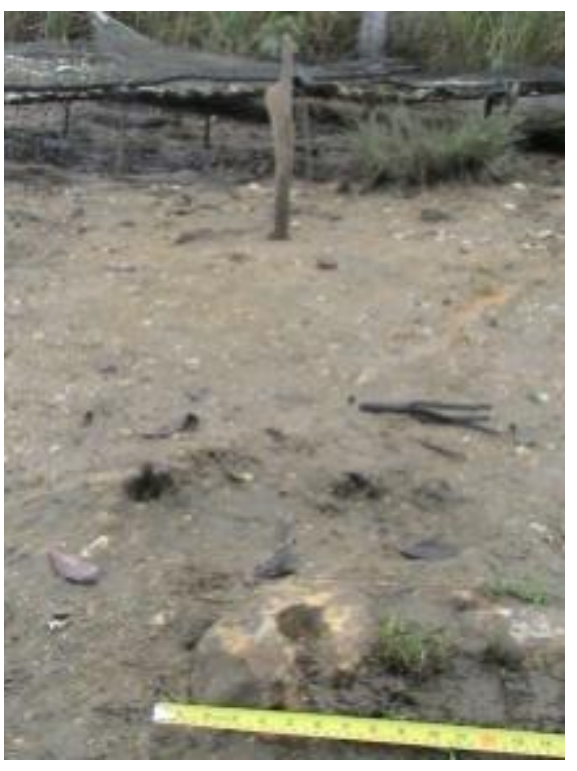

Figura 52: Marca de esteio na rocha.

Hoje em dia os Mandira utilizam o Porto Boacica e o Porto Zé Abrão. Entretanto, ambos portos foram ocupados e passaram a ser referência após o processo

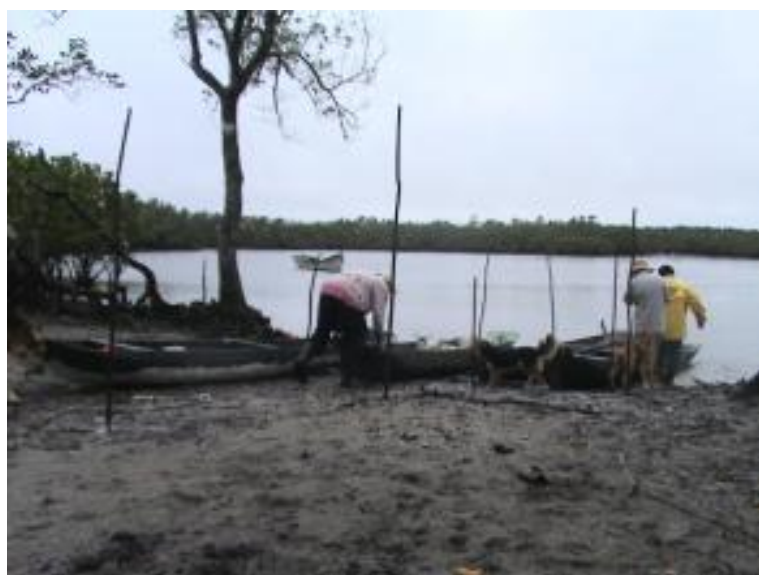

Figura 53: Porto Zé Abraão. de segregação dos Mandira no território. Antigamente, o porto utilizado como referência para a fazenda e posteriormente para o quilombo dos Mandira era o Porto-de-fora, conhecido originalmente como Porto do Mandira, por desembocar direto no rio Mandira. Contam que os sítios eram conhecidos pelo nome de seu porto principal. Assim, o primeiro porto era o porto do Mandira, 


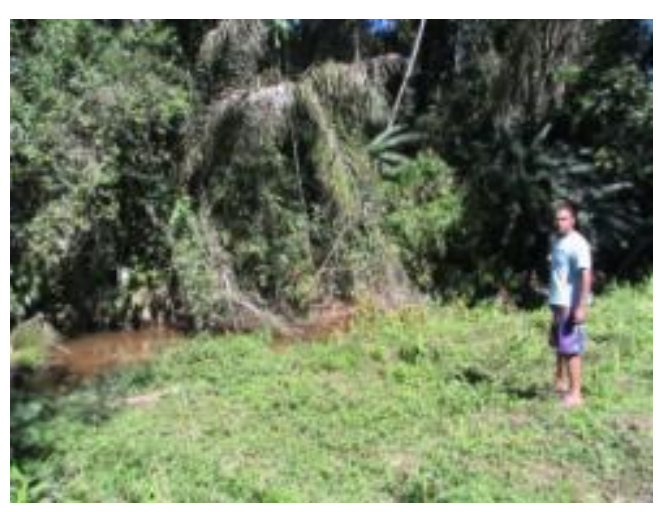

Figura 54: Porto-de-fora atualmente abandonado. por causa do rio do mesmo nome, mais para oeste existe o porto do Meio e em seguida o porto do Rio das Minas, que também levava o nome do rio. Seu Rubens lembra que o sítio do seu avô, Benjamin Constam de Oliveira, era conhecido como sitio do Porto do Meio, por referência a sua localização entre o porto do Mandira e o porto do Boacica (ver "Mapa Panorâmico" no Anexo 2).

Quanto às características físicas desses portos podemos dizer que são espaços naturais propícios às adequações necessárias às atividades sociais relacionadas ao seu ambiente. Segundo Bava de Camargo (2009:47-48) esse tipo de porto é "geralmente estabelecido em locais com boas condições naturais de ancoragem, muitas vezes numa desembocadura de rio ou estuário e não possuí cais ou pier". Entretanto, continua o autor: "[essas] áreas afeiçoadas (BLOT, 2003) estão longe de serem ambientes naturais, de serem portos naturais. Constituiriam ambientes onde as feições naturais foram trabalhadas pela ação humana com o intuito de maximizar suas qualidades imanentes. Em termos de

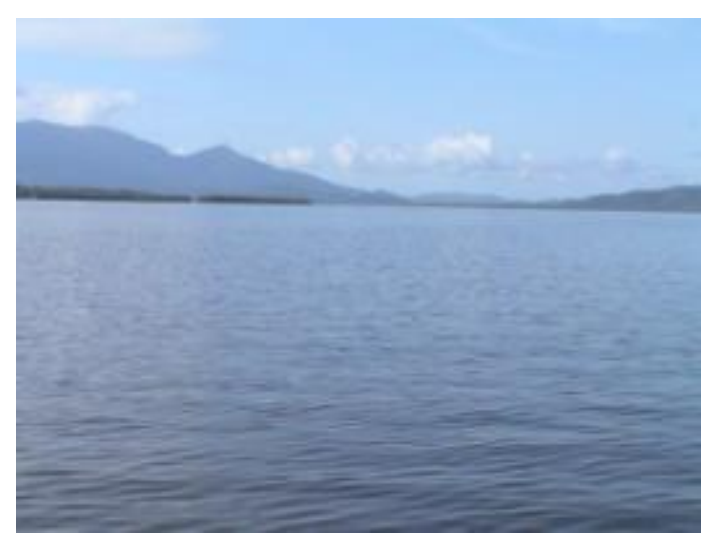

Figura 55: Barra do Mandira na maré alta.

estruturas materiais, o que caracteriza esses portos são sua espacialidade singular apropriada a mobilidade marítima (...)”.

Mais do que espaço físico, a Maré é uma rede de lugares interligados por rotas marítimas criadas e conhecidas pela rotineira atividade de pesca e coleta de matériaprima. A constante ocupação pela prática contínua dessas atividades conduz a organização social do espaço e a orientação cultural dos lugares por fatores ecológicos e marcadores simbólicos. O conhecimento e familiaridade com os elementos da paisagem é extraordinariamente demonstrada por um simples passeio de canoa. Para nós, "os de fora", o espaço é todo ele muito semelhante, ou seja, uma cenografia formada pelo infinito espelho d'água, banhando os pés das árvores do mangue que protegem a entrada de uma contínua área verde. Os morros ao fundo parecem estar de mãos dadas, 
contando ao céu sobre a vida na terra. Tudo parece estar muito perto, ao mesmo tempo em que a sensação de imensidão toca no fundo da alma para mostrar como somos frágeis. Aos olhos desconhecidos, as entradas dos rios e córregos parecem indissociáveis, dando a idéia de labirinto, já os mangues e morros das ilhas confundemse com os morros do continente, dando a noção única e contínua da paisagem.

Conversando com Bil, um jovem mandirense, perguntei como ele conhecia os lugares e sabia conduzir a canoa e barco nesse espaço. Ele respondeu com a maior naturalidade: "Eu conheço tudo por aqui!". Insisti para obter maiores detalhes: "Mas como você sabe onde é cada lugar? É pelos morros e vales? [era só o que eu podia distinguir na paisagem]" e ele, entendendo o que eu queria saber, respondeu: "É! $E$ pelos canais! Já andei por todos os canais.".

Mas não só os homens habitam esses lugares. Os mangues e canais de rios são lugares repletos de vida animal. Na descrição dos Mandira esses elementos adquirem características humanizadas, onde os peixes são representados com vida semelhante a do homem (DIEGUES \& NOGARA, 2005). Essas representações são percebidas nas histórias contadas pelos Mandira:

Segundo contam, houve um ano no qual um morador do Mandira foi pescar no dia da sexta-feira da paixão. Como todos sabem, esse dia é sagrado para os católicos, pois nesse dia acreditam que foi a morte de Cristo, por isso não se pode comer carne. Esse mandirano queria pegar uma traíra (peixe de água parada), então foi pescar em uma lagoa próxima a sua casa, que estava cheia de traíra. Logo chegando pegou uma ranzinha como isca e lançou a vara. Depois de algum tempo sem pega nada, trocou a isca por uma tripa de frango. Mesmo assim não teve resultado. Como última tentativa iscou um pedaço de carne. Nesse momento saltou uma enorme traíra, que olhou firme para o pescador e resmungou: "Hoje é sexta-feira santa, não comemos carne”. E foi embora

A história revela a intimidade com que os pescadores se relacionam com os peixes. Ao mesmo tempo em que os pescadores conhecem os lugares de morada dos peixes e por isso, fazem parte de suas vidas, os peixes são representados como seres que também partilham das crenças e temporalidade social dos Mandira, adquirindo em suas representações, comportamento e linguagem humana. $\mathrm{Na}$ formação da paisagem 
cultural do território dos Mandira, esses elementos naturais são representações carregadas de uma temporalidade socialmente construída, atribuindo significado aos lugares.

Assim, o peixe sabe que não pode comer carne nesse dia, assim como o pescador sabe que depende do tempo da maré para sair para pescar. Ou que a tainha se pesca no inverno e que "o rio preto é lugar bom de se pescar robalo". Todos esses saberes são construídos pela perspectiva de conhecimentos compartilhados entre pescador e peixe, que demonstram a fusão dos mundos, homem-natureza, ao mesmo tempo em que demonstra a fusão da perspectiva de tempo-espaço.

\subsection{Os antigos carreadores e os caminhos contínuos.}

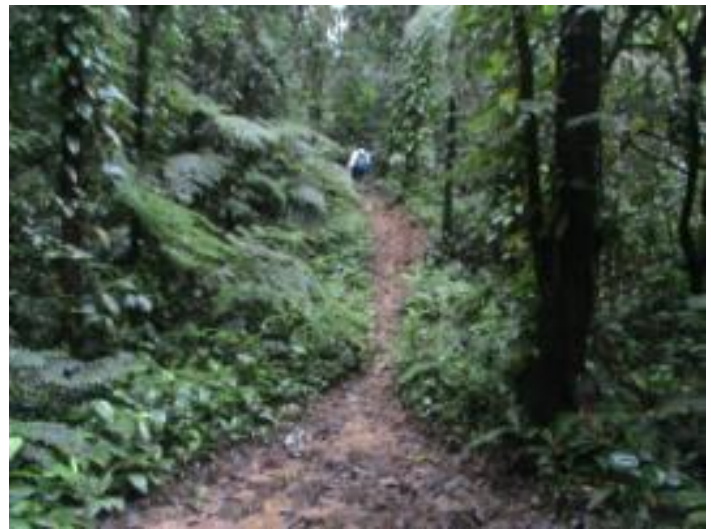

Figura 56: Caminho dos antigos. Trilha do Pindauva.

Além da paisagem alagada, o território é formado também pela paisagem terrestre, que compreende as vertentes dos morros, os sopés dos morros e uma faixa de terra plana estendida entre os morros e o início da área de mangue. Nessa extensão da paisagem encontramos a área de moradia, concentrada atualmente no sopé do morro, e um sistema de lugares significativos estruturados por caminhos e trilhas existentes no território quilombola dos Mandira.

As caminhadas diárias pela paisagem tornam os lugares familiares, começando a biografar encontros de indivíduos, reforçando traços de atividades, eventos e histórias do passado e leituras de sinais. Todos os lugares e paisagens são embebidos no tempo e na memória social e individual (TILLEY, 1994:27). Os caminhos dos Mandira estão marcados no território e incorporados em suas histórias e práticas diárias das atividades com a flora e fauna. Segundo seus moradores mais velhos, alguns destes caminhos sempre existiram. São lugares considerados por eles como "caminhos dos antigos" e fazem parte do movimento diário dos Mandira em seu território. Alguns levam aos portos ou as áreas de mangue e outros às cidades vizinhas. 
Também nesses lugares a presença das mulheres não é freqüente. Antigamente, as mulheres utilizavam alguns desses caminhos acompanhadas de seus maridos para visitar os parentes em outros bairros e cidades. Atualmente, com as estradas e o uso de carros, as trilhas e os caminhos do mato tornaram-se lugares exclusivos do universo masculino e mesmo assim, não são todos os homens que conhecem e sabem se deslocar por essas entranhas da mata.

Hoje, os Mandira sofrem com o conservacionismo das leis do código florestal que limita suas atividades no território. Entretanto, atividades como a caça, a roça e a extração vegetal sempre foram praticadas pelos moradores mais velhos do quilombo, quais faziam uso dos caminhos dos antigos como lugares e passagens para o uso dos recursos da mata. A utilização destes caminhos para a caça e o acesso às áreas de plantio e extração vegetal, ainda faz parte da percepção e incorporação do espaço habitado pelos Mandira.

Entre os Mandira, a diferença entre caminho e trilha faz parte do sistema de estruturação do espaço. Os caminhos são mais estreitos que as trilhas. Dona Irene Mandira conta que antigamente não se usava a denominação trilha. Os caminhos mais largos, usados com maior frequência, eram denominados carreadores. Esses carreadores ligavam as diferentes áreas de moradia entre si e essas áreas aos portos e vilarejos vizinhos. São estruturas mais largas, consideradas mais antigas, que fornecem acesso para fora do território. Já os caminhos eram mais longos e associados às matas fechadas, ligando as áreas de habitação aos diferentes lugares de atividades, como a roça ou os locais de coleta de materiais. São caminhos muitas vezes formados pelos próprios animais e apropriados pelos homens para a caça, agricultura, extração de madeira ou simples deslocamento pelo território.

Histórias são contadas referentes a biografia dos caminhos e carreadores antigos. São diferentes narrativas, que descrevem os caminhos como lugares comuns, presentes em atividades e acontecimentos de personalidades do passado. Contam que:

"em uma de suas caminhadas na mata, Antônio Vicente Mandira viu uma Irara arrancar uma colméia antiga, sem abelhas, de uma árvore. Já no solo, a Irara raspava a colméia com as patas dianteiras, arrancava o mel e sem se virar, colocava o mel na boca do filhote que se posicionava atrás dela. Seu Antônio, muito esperto, aproximou-se bem quietinho, e sem que a mãe Irara notasse, deu um cutucão no filhote colocando-se em 
seu lugar. Porem a mãe Irara, sem notar a mudança de lugares, continuou o movimento, colocando o mel na boca de seu Antônio, que se lambuzava de mel."

Histórias como essa são comuns nos Mandira. Trata-se de uma tradição oral com enredo narrativo simples e despropositado, mas, ao produzir o discurso sobre o passado, revela uma gama de relações possíveis de serem traçadas, tendo em consideração o presente e o futuro. Nessa narrativa, a figura de Antônio Mandira é lembrada pelo seu espírito perspicaz e descontraído, por "ocupar" o lugar do pequeno Irara e comer mel da mão da mãe Irara. Mas também por seu pleno conhecimento e alinhamento com os elementos desse ambiente da mata. Vale lembrar que Antônio Mandira sempre foi reconhecido como exímio caçador.

São histórias que relatam as formas como as atividades e comportamento humano estão estruturados em relação aos outros elementos e ações realizadas nesse ambiente. Por outro lado, explicam também como os elementos visíveis e invisíveis desse ambiente se portam. Os comportamentos dos animais são descritos nas narrativas conforme suas características naturais, mas com traços antropomórficos, próprias da variação do caráter humano. Uma lógica inversa parece fazer parte dessas narrativas, a qual, ao mesmo tempo em que aproxima os Mandira dos outros elementos presentes no território, também define o comportamento e lugares esperados para cada elemento. Assim, os lugares são habitados não só pelos Mandira, mas por outros seres classificados por eles pela relação entre os outros elementos, os lugares e as atividades próprias de cada lugar.

Novamente os nomes dizem muito sobre a biografia dos lugares. Os nomes dos lugares têm importante função por transformar algo que aparentemente é apenas físico e geográfico em algo com significado histórico e social. Pela ação de nomear perpassa todo o desenvolvimento humano de reconhecer e associar os lugares nomeados (WHITRIDGE, 2004).

Dois dos caminhos mais antigos do território Mandira são o Caminho do Pecê e a Trilha do Pindauva. Não se sabe quando surgiu o nome Caminho do Pecê, nem ao que ele se refere. Esse caminho liga os núcleos de moradia no sopé do morro ao mangue e canais. Já a Trilha da Pindauva possui maior extensão e liga o litoral ao bairro Pindauva, no município de Jacupiranga. Seu nome está associado a uma árvore, oriunda 
da região. Interessante que a palavra pindauva vem da família-linguística indígena TupiGuarani e significa "árvore dos caniços ou varas".

Estudos arqueológicos e relatos históricos comprovam a existência de muitos grupos indígenas horticultores, integrantes do tronco lingüístico Tupi ocupando essa região quando se deu a chegada dos colonizadores europeus (STADEN, 1979; SOUSA, 1971; SCATAMACCHIA, 1990; 2004; 2011). Os relatos dos primeiros viajantes e missionários da época comprovam a localização de Cananéia como local limítrofe da etnia carijó, que se estendia para o sul. A partir de Angra dos Reis para o norte, encontravam-se as etnias dos tupinambás e tamoios. Entre estes dois grandes territórios estavam os tupiniquins, interligando as duas áreas por uma grande rede de longas trilhas entre o interior do continente e o litoral.

Em um dos relatos históricos, Hans Staden aponta para o fato dos habitantes da região de São Vicente/Itanhãem serem "de uma tribo de selvagens brasileiros, os tupiniquins, cuja região se estende em oitenta milhas para o interior da terra $e$ quarenta ao longo da costa" (STADEN [1557], 1979:72). Segundo Petrone (1966), esses grupos indígenas eram mais acolhedores que seus vizinhos. Sua presença favoreceu a fixação de moradores no litoral sul do estado de São Paulo.

Como limite geográfico entre os povos horticultores ocupantes da região antes da chegada dos europeus, Cananéia também se configurou como zona limítrofe no período histórico. Situado no extremo sul do ponto terrestre do Tratado de Tordesilha, Cananéia tornou-se um importante ponto de apoio a navegação de exploração do novo continente. Em um ponto desta região encontrava-se o mestre Cosme Fernandes, conhecido como Bacharel, que chefiava uma população de 200 mamelucos juntamente com outros portugueses e castelhanos náufragos e degredados vivendo harmoniosamente com a população tupiniquim nativa. ${ }^{25}$ A presença desse personagem na região é ainda uma incógnita. Sua chegada também desafia as datas oficiais de descobrimento do Brasil, pois existe a possibilidade dele ter chegado antes da viagem oficial de Pedro Alvares Cabral, na expedição de Bartolomeu Dias relatada no Esmeraldo de situ orbis (SCATAMACCHIA, 2011:23). De qualquer forma, sua presença no continente é documentada oficialmente por Martim Afonso no local onde

\footnotetext{
${ }^{25}$ Pelo que consta, este homem foi desterrado pela Coroa Portuguesa para o Brasil, em nome de El Rei D. Manoel, pela Lei de Expulsão de 1447, inscrito no livro dos Degredos, do Museu dos Tombos, na capital pórtuguesa de Lisboa, com destino a $25^{\circ}$ de "ladeza" na costa que seria a ponta sul da ilha do meio, na futura capitania de São Vicente, porem é degredado na Ilha do Cardoso, provavelmente na praia de Itacurussá (MARQUES, 1952; CARVALHO, 2010).
} 
nascia o que seria um dos primeiros povoados brasileiros: "foi a Ilha de Cananéia, que a esquadra de Martim Afonso de Souza fundou a 12 de agosto de 1931" (MARQUES, 1952:161).

Baseado no diário de campo de Martin Afonso de Souza e Pero Lopes de Souza, pesquisas históricas descrevem que por trilhas como essas, partiu de Cananéia a primeira bandeira paulista em busca de ouro. Quando Martim Afonso de Souza aportou na ilha, recebeu a informação dos náufragos que residiam no local, de que as terras eram providas de ouro e prata em abundância. Francisco de Chagas, um dos náufragos que acompanhava o Bacharel, convenceu Martin Afonso a organizar uma grande expedição chamada de oitenta homens, composta de quarenta besteiros e quarenta espingardeiros, a qual, sob direção de Pero Lobo, oficial de sua armada, partiu em direção ao sertão desconhecido em $1^{\circ}$ de setembro de 1531 (TAUNAY, 1948).

Consta que Francisco Chagas tivesse sido um dos sobreviventes da expedição de Aleixo Garcia pelo caminho do Peabiru ao Império Inca, por isso teria aliciado Martin Afonso de Souza a organizar a expedição comandada por Pero Lobo ${ }^{26}$. O objetivo era encontrar a montanha de ouro e prata do poderoso rei branco do Império Inca, mas a expedição foi aniquilada antes de concluída. Todos os oitenta homens morreram, sem deixar vestígios. Sobre o rumo por ela tomado a partir de Cananéia, o historiador Afonso d'E Taunay (op. cit.) sugeri que a mesma teria penetrado ao sertão pela Barra do rio Taquari e rio das Minas, atravessado a Serra em direção ao campo de Curitiba, sendo sucumbida nas nascentes da Foz do Iguaçu.

Entretanto, não nos interessa propriamente inferir sobre a origem dessas trilhas. No momento basta entender como as trilhas são apropriadas e significadas pelos Mandira. Para eles, as trilhas sempre existiram. Provavelmente, quando os europeus chegaram ao novo continente, as trilhas podem ter adquirido diferentes significados simultaneamente atribuídos pelos brancos e pelos povos autóctones. O que interessa é registrar o fato das trilhas seguirem existindo, acompanhando outros modos de uso e formato, como um palimpsesto de significados atribuídos a um mesmo lugar (ANSCHUETZ et al., 2001; ASHMORE, 2009).

\footnotetext{
${ }^{26}$ A personagem de Aleixo Garcia aparece como figura lendária entre as pesquisas históricas sobre as primeiras expedições colonizadoras do novo mundo. Benedito Calixto, em um dos primeiros escritos sobre o tema, especula que os rumores de sua expedição aos Andes despertaram a cobiça pelos metais preciosos entre os primeiros colonizadores do litoral (Calixto, Benedito. Vila de Itanhaém. Segundo povoado fundado por Martin Afonso de Souza em 1532. Santos: Diário de Santos, 1895.)
} 
Assim, existem outras trilhas e caminhos antigos no Mandira, como o Caminho do Cavalo, o Caminho do Mato, o Caminho do Porto Boacica, a Trilha do Porto-de-fora e o Caminho das Areias. A longevidade de existência destas trilhas parece ter produzido um senso de ligação entre a população e esses lugares, resultando na corporificação do lugar enquanto espaço socialmente produzido (BROWN, 2004). As trilhas e caminhos apresentam-se como meio de projeção das relações sociais, conectando impressões espaciais com a temporalidade inscrita na memória coletiva do grupo (TILLEY, 1996).

Muitas histórias de relacionamentos que terminaram em casamentos ou aliança e amizades entre membros de diferentes comunidades são contadas em torno de casos que envolvem a existência dos caminhos e trilhas. Os jovens contam admirados que os mais velhos costumavam percorrer a trilha do Pindauva semanalmente para vender peixes na comunidade vizinha. Relatam que enfrentavam os trechos de morros ingrimes da longa trilha, com os peixes nas costas para comercializar na comunidade do interior. Outras narrativas dos jovens sobre a mesma trilha, contam das atividades de lazer como festas e jogos de futebol que aconteciam entre as comunidades nos fins de semana. Nessas ocasiões (que segundo eles não faz mais do que dez anos atrás), juntavam um grupo de pessoas com seus familiares (pai, mãe e filhos pequenos) para percorrerem a trilha juntos e encontrar os amigos e parentes nos bairros vizinhos.

Outra trilha que também está muito presente na memória dos moradores do Mandira é a trilha do Porto-de-fora. As histórias dessa trilha rememoram os tempos da fazenda dos Andrades. Dona Saturnina lembra das histórias que sua mãe contava sobre a filha do Antônio Florêncio de Andrade, a sinhá Celestina de Andrade. Segundo ela, Celestina era uma mulher muito grande e gorda, que não gostava de caminhar. Quando a sinhá chegava no porto da fazenda (o Porto-de-fora), os escravos tinham que preparar uma carroça para busca-la. A senhorita ia sentada, enquanto precisava de pelo menos dois escravos para puxar a carroça por todo o caminho do Porto-de-fora até a casa dos Andrades. Dona Saturnina conta o fato com ares de sátira, mas ao mesmo tempo, com desaprovação e indignação. A história é lembrada como um ensinamento transmitido por gerações, podendo adquirir interpretações diversas em torno de formas simbólicas de domesticação do capataz: representação do modo como os senhores dependiam dos escravos para fazer tudo, tendo que ser literalmente carregados nas costas; ou ainda mostrar como seus descendentes escravos conheciam as terras, caminhando por todos os lugares, ao contrário dos Andrades, que não chegavam a pisar nas terras da fazenda. 
Dona Saturnina lembra que quando ela era criança, existia muitas casas ao longo da trilha do Porto-de-fora. Ela mesma nasceu e passou sua infância em uma casa na beira desse carreador. O carreador era estreito e envolvido pelo mato. As casas ficavam a poucos metros do carreador, rodeadas pelo mato denso. Nessa época as pessoas não tinham costume de cortar o mato sem necessidade. Seu Rubens lembra dessa época como algo muito distante, com costumes muito diferentes dos de agora. Segundo ele os antigos gostavam de viver no meio do mato. Quando ele e seus irmãos cogitavam cortar o mato que crescia em volta das casas, seus pais e avôs não deixavam. Ele conta que apenas quando pretendiam plantar um pé de café e cultivar uma roça era permitido roçar o mato em volta da casa. Desse modo, eles limpavam a área e faziam a roça bem próxima das casas, ao longo dos caminhos.

Entretanto, ao descrever as características físicas dessas trilhas e caminhos encontramos poucos marcadores de ocupação e uso que apresentem a perspectiva de longa duração de sua história: são caminhos muito bem conservados, com alguns trajetos cobertos com um piso feito de troncos cortados e/ou prancheados e alinhados no solo. Outros trechos são mais largos, com o piso feito de granito e pedras maiores. Existem ainda diversas pontes ao longo das

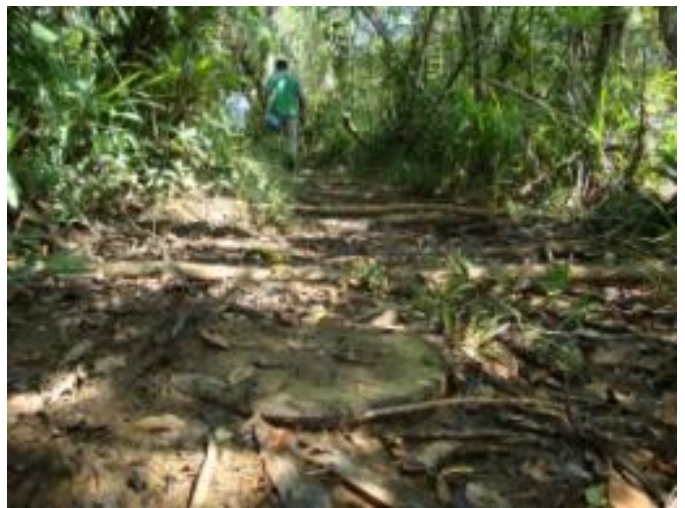

Figura 57: Caminho do Pecê. trilhas, feitas por eles com troncos. Em algumas dessas pontes podemos ver a sobreposição das construções e o aperfeiçoamento nas técnicas de corte e posicionamento das madeiras.

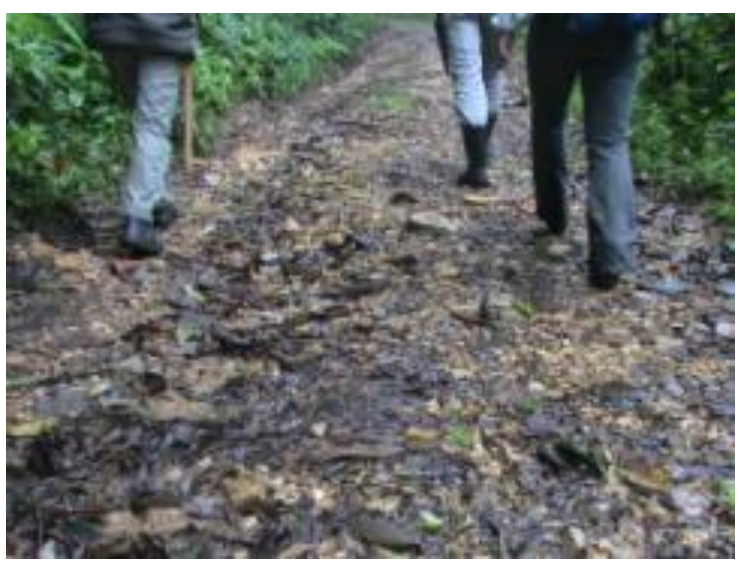

Figura 59: Caminho do Pindauva.

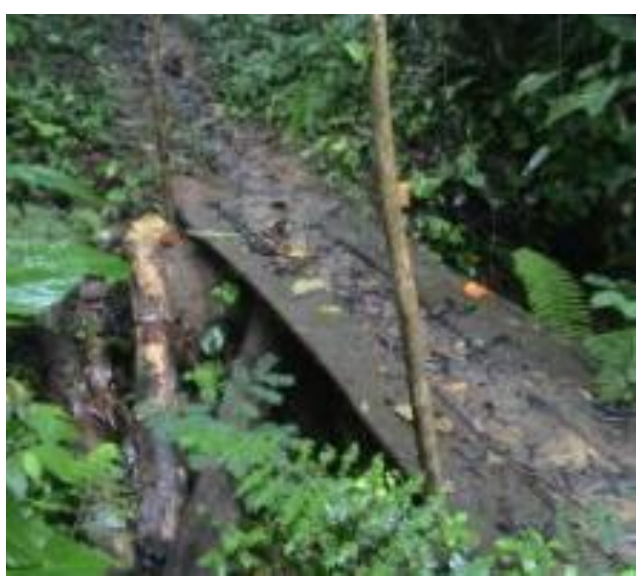

Figura 58: Pontes nas trilhas. 
Ao longo deles encontramos marcos paisagísticos que indicam antigas áreas de moradia, como árvores frutíferas (bananeiras, figueiras, mangueiras, abacateiros, cajueiro, etc) e ervas utilizadas para prognósticos curativos, como alfavacão (Ocimum officinalis L.), carqueja (Baccharis trimera (Less.) DC. Família: Asteraceae), capitiu ou limão-bravo (Siparuna guianensis Aubl. Família: Monimiaceae), capiá ou capim-de-nossa-senhora (Dorstenia multiformis) e outras que ainda hoje são encontradas no entorno das casas. Outros vestígios encontrados ao longo do caminho são cascas de ostra trituradas e espalhadas pelo solo. Mesmo na trilha do Pindauva, que leva ao topo do morro, em alguns lugares planos, onde encontramos árvores frutíferas, também podemos encontrar os vestígios de cascas de ostra distribuídas no entorno. A presença desses vestígios indica as áreas de moradia de um passado recente, quando ainda acontecia constante atividade de desmariscar no entorno das casas.

Os próprios Mandira chamam atenção para esses vestígios quando fazemos a prospecção nos locais de tapera (locais de antigas moradias). Eles diferenciam os vestígios e sinais relacionados às atividades de ocupações antigas, de evidências das ações de pessoas das comunidades do entorno que freqüentam as trilhas. $\mathrm{O}$ ato de caminhar pelo território para realizar atividades básicas do cotidiano como caçar, coletar frutas, coletar sementes e cipós para artesanatos e acessar as comunidades vizinhas e os portos, é um processo de apropriação do sistema topográfico e das características físicas do lugar (TILLEY, 1994:28). Caminhar torna-se para os Mandira um ato de ocupação, vigia e preservação das terras de seu território.

Eles identificam também outros sinais imperceptíveis para nós, "os de fora", como pegadas e rastros de animais, ao longo dos caminhos. Demonstrando um conhecimento transmitido pelas histórias e atividades de caça de seus antepassados. Conseguem saber quais animais freqüentam determinados lugares observando as árvores e frutos marcados por roedores ou encontrando os buracos e tocas dos bichos.

\subsection{Caça e agricultura.}

Antigamente, os Mandira costumavam manter uma cabana para a atividade de caça em lugares estratégicos, afastados dos núcleos de moradia. Nos meses de caça, um grupo de homens organizava excursões de alguns dias para praticar a caça e sociabilizar 
histórias e ensinamentos nestes locais. Um desses lugares era no Açungui, próximo ao Rio das Minas, também conhecido como Rio das Pratas ou Serra do Cadeado. Seu Chico conta que antigamente vinham parentes e amigos de Pindauva para acompanhar a excursão de caça no Açungui. Todos sabiam que a caça lá era abundante e ninguém voltava pra casa sem carne, principalmente carne de anta e porco-do-mato. Eles passavam dias acampados, secavam a carne pra trazer tudo seco. Hoje, a caça é proibida na região. Apesar disso, essa prática ainda está viva na memória dos moradores como um conhecimento ancestral significativo ao entendimento, uso e relacionamento com o território. A caça deve ser entendida como um conjunto de práticas expressivas sobre o modo de relacionamento do povo com seu espaço físico e extra-físico. Sua prática estava plenamente embasada na territorialidade própria dos Mandira.

Com exceção do porco-do-mato e do cateto, que procriam durante todo o ano, as outras caças tem o tempo e o lugar certo de caçada. Normalmente, caçava-se nos meses

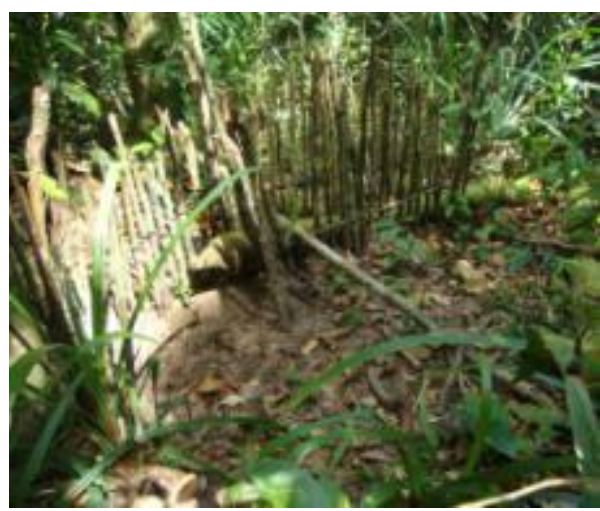

Figura 61: Mundéu abandonado. sem "R" (maio, junho, julho e agosto). Neste período de inverno, os animais não estão procriando e os Mandira podiam armar o mundéu, preparar as armadilhas na ceva e ficar a espreita das caças nos trepeiros. O mundéu é uma armadilha de caça para todo tipo de animal rasteiro, como paca, tatu, quati, raposa e cotia. $\mathrm{O}$ princípio do mundéu é uma arapuca armada para o animal, acionada pelo movimento da presa. Usa-se um tronco de madeira de cerne (pois são as mais pesadas) ou uma laje de pedra, apoiada por um pequeno galho, a guisa da arapuca. Em baixo colocase uma isca e em volta constroem um cerco, com a única entrada na direção do galho de apoio. Assim, quando o animal entra no cerco para comer a isca, desloca o galho de apoio, sendo atingido pelo tronco.

Procuravam armar o mundéu nos carreiros. Os carreiros são pequenos rastros que sinalizam no solo a passagem de pequenos animais. Conforme seu formato, os Mandira sabem classificar o tipo de animal

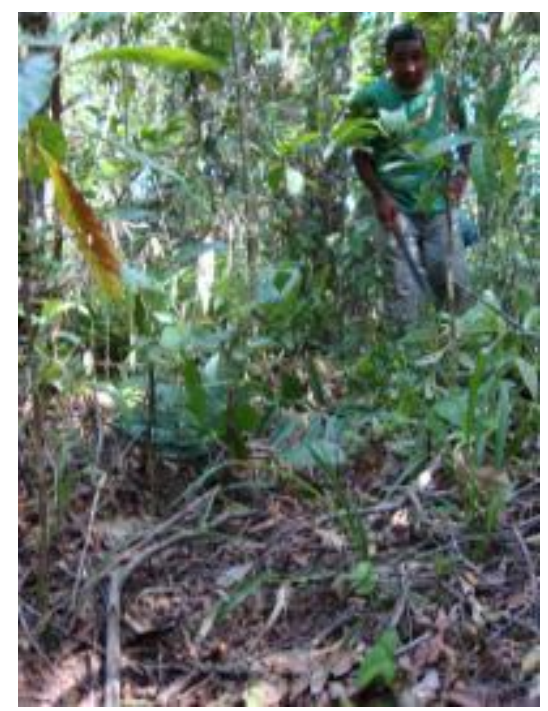

Figura 60: Carreador sinalizado. 
que passa no local. Já os animais maiores, como cateto, porco-do-mato e veado, deixam pegadas no solo e a dificuldade para abatê-los é maior. Normalmente faziam trepeiros perto das plantações, pois sabiam que o cateto, a paca e o veado frequentam os lugares de roças para comer feijão e folha de batata-doce e a cotia para se alimentar da mandioca. O trepeiro nada mais é do que uma escada construída entre duas árvores, onde o caçador pode ficar no topo a espreita do animal.

As cevas são pequenas clareiras na mata (sua extensão é proporcional ao tamanho do animal que se pretende caçar), onde é colocado algum alimento para servir de isca. Próximo à ceva o caçador fica de tocaia no trepeiro. Quando o animal entra na ceva pra comer a isca é abatido pela pontaria do caçador.

Outro tipo de armadilhas comum são as armadilhas de laço, que podem ser armadas de diferentes formas, apresentando técnicas e conhecimentos diversos, mas normalmente se usa o nó de correr (conforme desenho 1 da figura 61). Um tipo de laço são os armados no chão, em cima de um graveto que aciona a armadilha; tudo é escondido com folhas secas por cima no meio do carreiro, para quando o animal passar, pisar no graveto, esticar a corda e ser agarrado na perna pelo laço. Existe também o laço de pegar gambá e paca: este é amarrado aberto na entrada de um cerco, em posição vertical, com um graveto no meio (conforme desenho 3 da figura 61). Dentro do cerco coloca a isca para atrair o animal. Quando ele entra no cerco, desloca o graveto, o laço arma e pega o bicho pelo pescoço.

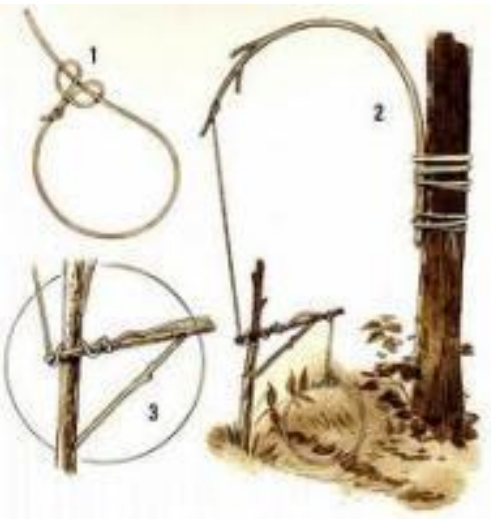

Figura 62: Laço pra caçar gambá e paca. (Fonte: http://triboescoteira.blogspot.com.br/200 8/02/armadilha-ii-armadilha-de-lao-i-1faa.html)

Nos Mandira é muito comum as armadilhas de pegar passarinho. Uma delas era o mundéu Apique feito com uma vara enfiada em uma raiz onde coloca-se a isca e outra envergada para cima com auxílio de uma vara mais fina. Quando o passarinho ciscar na isca, movimenta a vara de apoio e é surpreendido pelo impacto da vara que estava envergada, atingindo-o com violência. Outra armadilha é a forca pra passarinho corta-se a embaúba, lasca-se uma parte da vara e abrem-se as extremidades com outra vareta. $\mathrm{Na}$ lasca que fica em baixo põe-se a comida e amarra-se uma corda que passa pela lasca de cima. O caçador fica na espreita. Quando o passarinho pousa para comer, ele puxa a corda e as duas lascas se juntam no pescoço do bicho. 
Existe também a esparrela: em uma ripa fazem-se dois furos onde em um amarra-se a corda e em outro uma fruta de isca. Na corda faz-se um laço e coloca em uma vareta em frente a ripa, posicionada como um poleiro, onde o passarinha pousa para comer a fruta. Quando o passarinho pousar na vareta ela pende e o laço corre pegando o passarinho pela pata. Por fim, existe a arapulca convencional, conhecida de

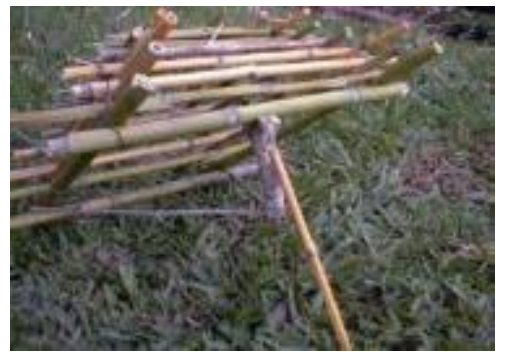

Figura 63: Arapuca para pegar passarinhos. forma geral como uma gaiola piramidal, feita de ripas de madeira trançadas. A armadilha é armada com uma isca dentro da gaiola, que é levantada por um graveto apoiando um dos quatro lados. A pessoa fica a espreita segurando uma corda presa ao graveto. Quando o passarinho vai comer, o graveto é deslocado e a gaiola fecha com o animal dentro.

Antigamente os laços eram feitos com a corda fabricada do linho da folha do tucum. Com os materiais industrializados outras armadilhas foram criadas, como o Jequi e a rede. A rede é usada para capturar principalmente o tatu. Ao descobrir o buraco onde o tatu está escondido, arma-se um sistema de catapulta com a rede amarrada na ponta de um galho de árvore: escolhe-se um galho de árvore flexível o suficiente para envergar até a entrada do buraco e não quebrar; amarra-se a rede na extremidade do galho tampando-se a boca do buraco; por fim, prende-se o galho envergado com um sistema de gravetos para ser liberado quando o animal entrar na rede; ainda amarrada na ponta do galho, a rede é lançada no ar, desenhando uma meia esfera, tendo o galho como raio. Depois de bater de um lado à outro no chão e no mato ao redor, o animal fica preso na rede até ser retirado no dia seguinte.

Já o Jequía é uma armadilha que se coloca na toca do bicho feita de arame. Prende-se a boca da armadilha na toca do bicho, deixando a extremidade afunilada em pé, posicionada apenas com um graveto leve, onde prende a tampa também levantada por um fio. Quando o tatu sai da toca e entra na armadilha o graveto libera o fio que solta a tampa fechando a armadilha com o bicho dentro.

Muitas outras armadilhas devem ter sido inventadas e reinventadas por eles, compartilhando conhecimentos e práticas regionais. Desse modo, não nos foge a percepção de que a atividade de caça envolve um conjunto de regras e conhecimentos relacionados a lugares, períodos e recursos específicos que são sociabilizados. A prática do caçador revela um conjunto de saberes culturalmente estabelecido em torno de 
diferentes atividades, envolvendo os elementos da terra, que por essa relação do material e imaterial na territorialidade, formam os marcos no território dos Mandira.

Outra atividade que envolve o conhecimento dos recursos da terra e marca a paisagem do território Mandira é a agricultura. Os lugares de roças antigas são denominados por eles de tiguera. Seu Bernardo se vangloria de seu tempo, quando todos trabalhavam na roça. Quando questionado onde encontrar tigueras hoje em dia, ele debocha: "faziamos roçar em

todos os lugares. Roçávamos tanto que chegava até próximo daqui [onde hoje é o atual núcleo de

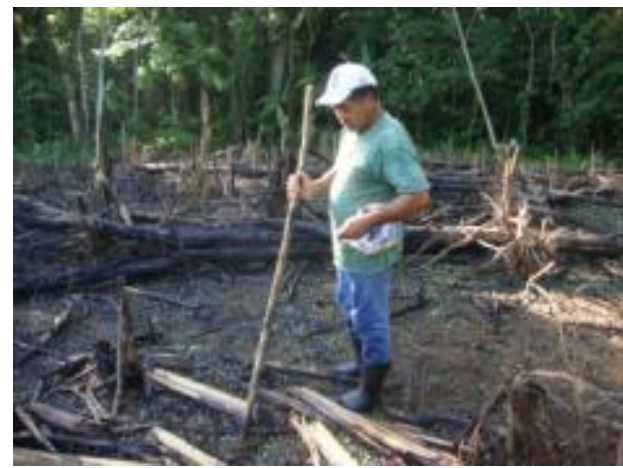

Figura 64: Seu Chico semeando a terra. moradia, distante aproximadamente quatro quilômetros do antigo núcleo]". Ele explica que as roças eram feitas em forma de rodízio, para o descanso da terra. O sistema de plantio praticado era o da coivara realizado em cinco etapas: primeiro a limpeza do terreno com a foice e o machado para derrubar as árvores altas; depois a queima da matéria orgânica; seguido do período de enriquecimento da terra; em seguida carpia; para finalmente abrir as covas e semear. O material usado para abrir as covas é um pedaço de pau simples. O semeador carrega as sementes em uma bolsa feita de cipó timbopeva denominada saquipé. Conforme a mão direita finca o pau na terra e abre a cova, a mão esquerda saca as sementes do saquipé e lança-as no buraco, em seguida o mesmo pau que abriu torna a fechar a cova para que os pássaros não comam as sementes antes de germinarem.

Todo o processo da coivara tendia a se repetir por algumas vezes no mesmo lugar até a terra dar sinais de fraqueza, percebidos pela baixa produção de materiais orgânicos entre uma queimada e outra. Assim, seguia-se um período de pousio ou descanso desta área, que durava aproximadamente cinco a sete anos, até que ela estivesse reestabelecida para voltar a ser explorada. Durante este período outra área era utilizada.

Não existia divisão das terras ou lugares delimitados para o plantio. "A terra era de todo mundo da família, era herança”. A roça era de quem trabalhava nela. Dependendo da cultura que o agricultor iria trabalhar e dos lugares de plantio anteriores, os melhores lugares eram escolhidos. Nas partes mais alagadas plantavam arroz, nas partes mais secas plantavam milho, feijão, batata, cara, perto do morro e envolta das 
casas plantavam rama e ao longo do rio Mandira plantavam pé de café. Cana e banana plantavam em todos os lugares.

A produção agrícola era dividida pelos núcleos familiares em roçados de até cinco hectares dependendo do tamanho da família. Cada família organizava sua roça do tamanho que poderiam cuidar e alimentar as pessoas daquela área. As roças eram feitas pela prática do ajutório. Ajutório é o trabalho na roça com menos pessoas que o mutirão e não tem festa e dança no final, apenas o almoço ou jantar. Segundo Seu Frederico, os Mandira praticavam apenas o ajutório, talvez por que a família foi sempre grande na comunidade e não precisava convidar muitas pessoas de fora. Mas eles sempre foram aos mutirões de outras comunidades.

Hoje em dia os Mandira tendem a retomar a prática de fazer roça. Os mais velhos demonstram sinais de que não querem que esses conhecimentos se acabem com eles. Alguns moradores querem retomar as roças para ensinar seus filhos como se cultiva a terra para plantar milho, arroz, feijão, mandioca. As áreas procuradas para as novas roças são as mesmas de antes: próximas ao rio Mandira, na trilha das Áreias, onde inicialmente habitava a família Mandira. Vamos especificar a diante como se constituíram esses lugares na história do território Mandira e como esse processo influencia no modo como o território quilombola e seus elementos constitutivos, incluindo os sítios arqueológicos, são compreendidos e preservados como patrimônio cultural. 


\section{AS DIVERSAS OCUPAÇÕES NO TERRITÓRIO MANDIRA}

\subsection{Lugares de histórias e histórias dos lugares: os sítios arqueológicos.}

Sabemos que o modo de vida dos Mandira mudou muito nos últimos 50 anos. Como vimos, antes eles caçavam, pescavam, faziam roça e utilizavam todos os recursos que obtinham pelo saber tradicional, mas hoje os Mandira são proibidos de ocupar a maior parte de seu próprio território. Para Seu Chico, os antigos não habitavam aleatoriamente a região no entorno da trilha do Porto-de-fora. Segundo ele, a sede da fazenda era nessa área, por ser o local plano e semi-plano de maior extensão no território. Da mesma forma, encontramos nessa área muitas tigueras (local de antigas roças), pois é unânime entre os Mandira a opinião de que as terras são mais férteis nos meandros mais a vazante do rio.

Trata-se de um espaço de aproximadamente três quilômetros quadrados, repleto de recursos naturais e lugares significativos, socialmente definidos, que contam um pouco da história dos Mandira. Na segunda metade do século XIX, quando as pessoas podiam usufruir livremente dos recursos de seu território, aplicando os conhecimentos transmitidos por gerações passadas, toda essa área era repleta de casas distribuídas em núcleos familiares e envolvidas por áreas de cultivo.

Como podemos observar pelos dois mapas históricos, a maioria das áreas cultivadas eram próximas às casas que estavam localizadas entre a baixa vertente do morro e o começo da área de mangue. Segundo os pontos coletados no trabalho de prospecção e pelas informações das histórias orais, o mapa temático do território, que ilustra a paisagem cultural dos andira no fim do século XIX, apresenta as taperas e tigueras localizadas ao longo da trilha do Porto-de-fora e na trilha das Areias (ver "Mapa Histórico: fim do século XIX" no anexo 1). No entorno das casas encontramos as áreas de pomar, banana e rama. Ao longo do rio Mandira existiam alguns pés de café. E ao longo da Trilha do Porto-de-fora, praticavam o cultivo do feijão, arroz e milho. A trilha do Porto-de-fora interliga o porto à região denominada de Casa-de-pedra, em referência ao sítio histórico mais representativo do território Mandira: o engenho da fazenda dos Andrades. 


\subsubsection{A Casa-de-pedra/ 0 engenho de arroz.}

Conforme vimos, existiam muitos engenhos de arroz em Cananéia e em toda região do Baixo Vale do Ribeira. Nesses engenhos os grãos de arroz eram beneficiados e armazenados (FRANCHI, 1999; VALENTIM, 2006). Encaixada no sopé do morro e no fim da trilha do Porto-de-fora (UTM 22J 0796214/7231542), o antigo

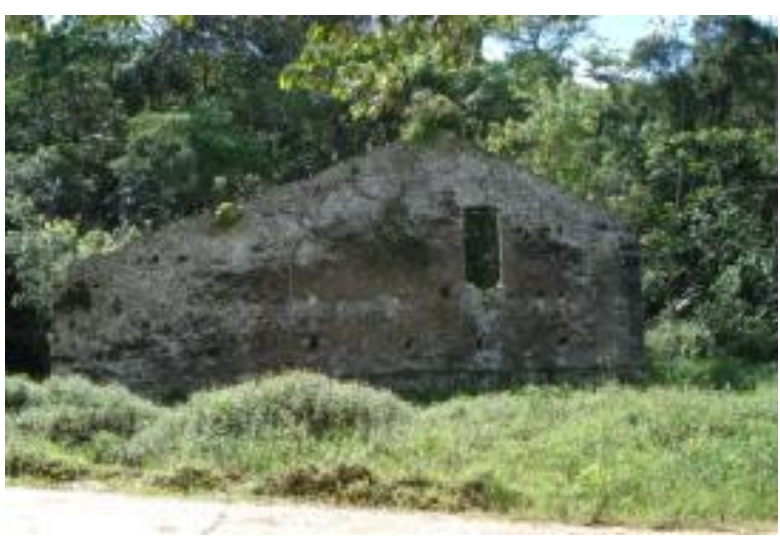

Figura 66: Fachada frontal da Casa-de-pedra do Mandira.

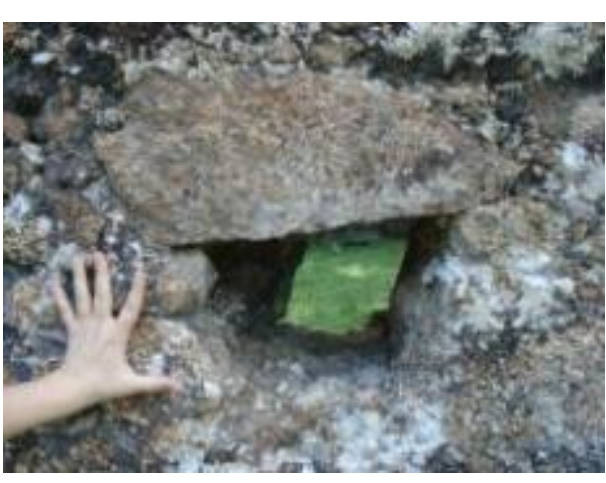

Figura 65: Detalhe do tamanho das pedras, da fresta e da argamassa. engenho de Arroz da fazenda dos Andrades, denominado pelos Mandira de Casa-de-pedra, apresenta o mesmo padrão arquitetônico das demais existentes no Baixo Vale. Sua estrutura é quadrangular construída com pedras brutas de diferentes tamanhos, encaixadas umas às outras com argamassa produzida pela mistura de óleo de baleia e conchas trituradas, provavelmente dos sambaquis.

O telhado de duas águas é dividido por dois lados laterais com paredes de tamanhos distintos. A fachada frontal não possui porta, apenas pequenas frestas entre as pedras e uma janela alta no lado em que a queda do telhado é menor. Na lateral mais baixa, formada pelo maior declive do telhado, tem uma porta de entrada. Na outra lateral (de menor declividade do telhado) a parede é mais alta e apresenta três janelas e uma porta (conforme figura 67). $\mathrm{Na}$ fachada posterior encontramos uma janela posicionada de frente com a janela da fachada frontal e dois vãos menores posicionados mais à baixo, próximos a lateral de maior declividade do telhado

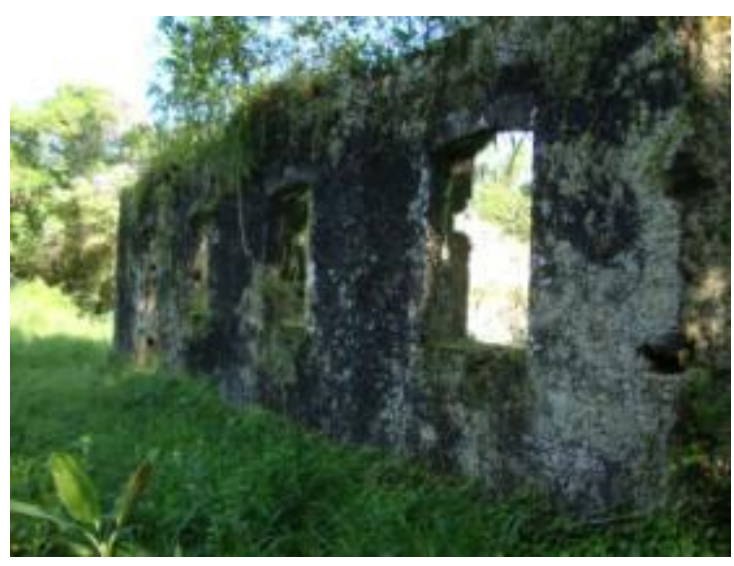

Figura 67: Lateral de paredes altas com três janelas e uma porta. 


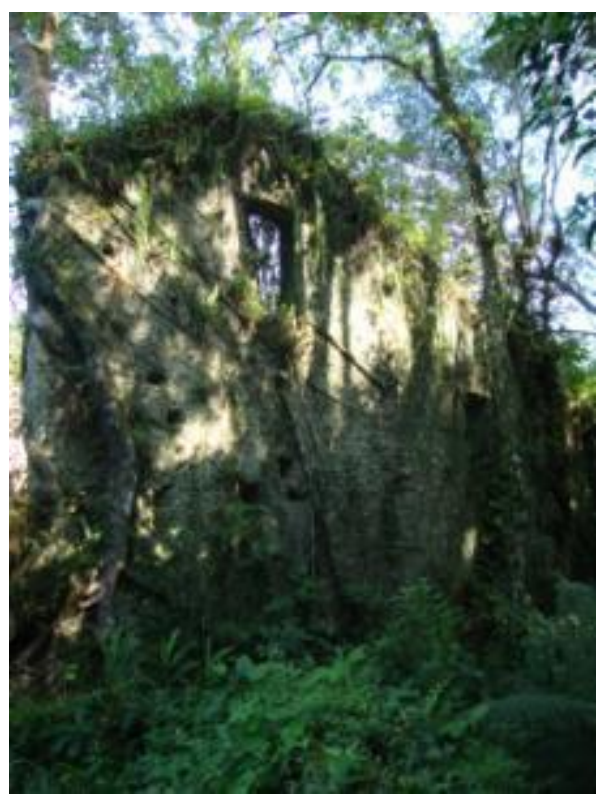

Figura 68: Fachada posterior.

(conforme figura 68).

$\mathrm{Na}$ parte externa dos fundos do engenho, conduzindo à abertura mais baixa da parede, encontra-se a feição de uma vala evidenciada no solo de aproximadamente um metro de largura, que se estende para cima do morro, cavada entre as pedras da vertente. $\mathrm{Na}$ parte interna encontramos uma estrutura de pedra ao centro da casa. Provavelmente essa estrutura é remanescente de uma parede divisória, paralela às paredes laterais que separava o local do moinho funcionando pelo movimento hídrico, com água que entrava e saia pelas aberturas na parede dos fundos - dos outros pavimentos de processamento e armazenamento de produtos. Essa inferência ganha força pelo fato de que nesse último compartimento interno encontram-se todas as janelas baixas da construção, sendo um ambiente de boa ventilação, próprio para armazenar os produtos.

Segundo os estudos de Franchi (1999:56) sobre arqueologia histórica do baixo Vale do Ribeira,

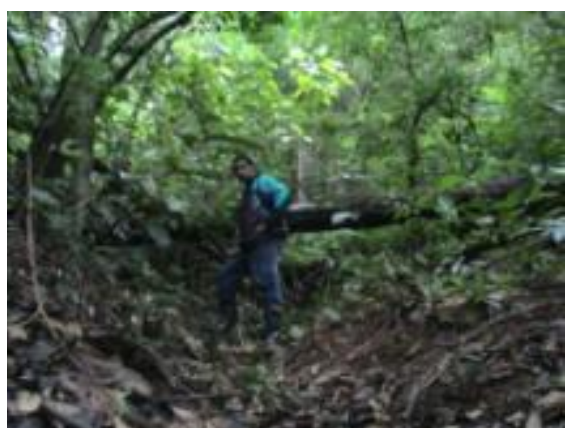

Figura 69: Luis na vala de condução hidráulica na vertente do morro. as construções de pedras, típicas na região, remetem a época de prosperidade econômica das fazendas com a cultura do arroz, o ciclo da mineração e a construção naval, durante os séculos XVII e XVIII. Assim, a maior parte dessas ruínas seria de antigos engenhos e

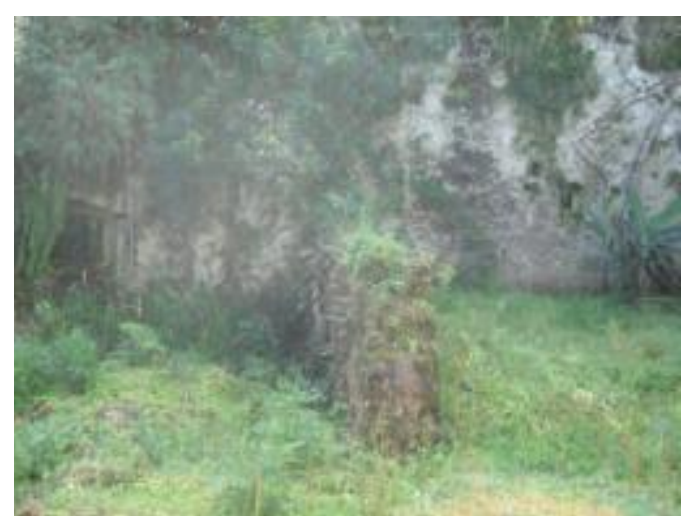

Figura 70: Vestígio da parede divisória interna. Detalhe para o vão na lateral esquerda da parede, por onde entrava a água para mover o moinho. de suas obras hidráulicas: "São deste tempo as histórias sobre os escravos que ainda estão bem vivas no imaginário popular. Eles teimam em chamar qualquer ruína construída com pedras de senzalas."

Os moradores do Mandira sabem que sua história não remete às senzalas. Dizem até que os Mandira nunca foram escravos, pois sua história começa com o filho liberto fruto 
da relação entre a escrava e o senhor da fazenda. Entretanto, isso não os impede de associarem essa estrutura arqueológica à sua identidade e apropriá-la como herança dos seus descendentes escravos.

Segundo Nei Mandira, estas estruturas foram construídas pelo suor e sofrimento dos escravos. Feitas de pedras rústicas dos rios e morros, areia e uma mistura de óleo de baleia e conchas moídas, foram erguidas para beneficiar o arroz. O benefício do arroz exigiu uma estruturação engenhosa. Nei conta com orgulho que os escravos abriram valas de cinco quilômetros de percurso em meio à mata fechada, para deslocar água de três cachoeiras com intuito de girar os moinhos.

Além da construção do engenho, todos os trabalhos da fazenda do Mandira eram feitos pelos escravos. Eles também eram responsáveis pelas etapas de produção e comercialização do arroz, desde o benefício do arroz, armazenamento, transporte ao porto de Cananéia, feito de canoa a vela ou à remo, até o carregamento dos navios, para então serem escoados aos outros pontos. Por isso, hoje os Mandira apropriam-se desse sítio arqueológico como vestígio material de sua história de ocupação, reivindicando assim, o direito ao uso e gerenciamento desse lugar, como parte de seu território.

\subsubsection{A Casa-de-pedra/ A Revolução de 1932.}

A percepção dos Mandira é a de que seu patrimônio é desvalorizado e ignorado frente aos outros. Para eles seu patrimônio cultural nunca terá tanta importância ou será tão representativo quanto o patrimônio nacional. Talvez por isso, também fazem questão de apresentar a casa-de-pedra aos visitantes como sítio histórico da revolução de 1932.

Sabe-se que o município de Cananéia foi palco dos conflitos entre as tropas federais do sul do país com as tropas paulistas durante a revolução de 1932. Cananéia é um município estrategicamente localizado como última cidade da costa do Estado de São Paulo. Sua porção de terra continental abrigou desde 1840 a antiga linha do telégrafo que se comunicava com Curitiba, São Paulo e Rio de Janeiro. Por essas razões tornou-se um local estratégico ao posicionamento defensivo das tropas paulistas. Contam que a casa-de-pedra serviu como alojamento às tropas.

Os mais antigos moradores do Mandira lembram quando as tropas armadas ocuparam e transformaram o local em palco de confrontos entre tropas paulistas e 
gaúchas. Todos da região foram obrigados a deixar as casas e se afastar da frente de batalha por alguns meses, até as tropas irem embora. Os habitantes do Mandira que não tinham outro lugar para ir, buscaram abrigo na região das "Areias", do outro lado do rio Mandira, próximo ao mangue. Como as famílias tiveram que abandonar suas casas, vivenciando as mazelas da guerra, de alguma forma, os Mandira também se sentem parte da história nacional. Eles se orgulham de expor a edificação como marco

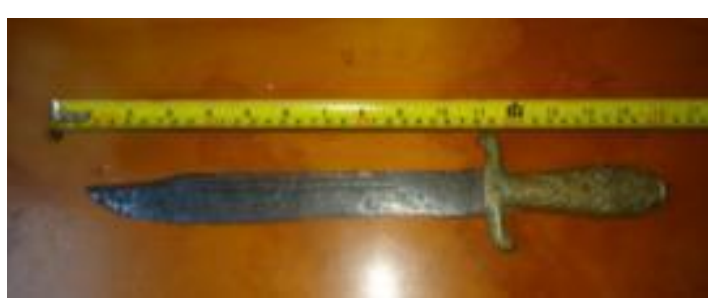

Figura 71: Lâmina de faca, com cabo estilizado, encontrado na região. histórico da memória de resistência de seus ancestrais vinculado a um fato histórico do Estado.

Alguns moradores guardam ou ainda hoje encontram espingardas, balas de fuzis, lâminas de facas, espadas e outros objetos que correspondem provavelmente aos

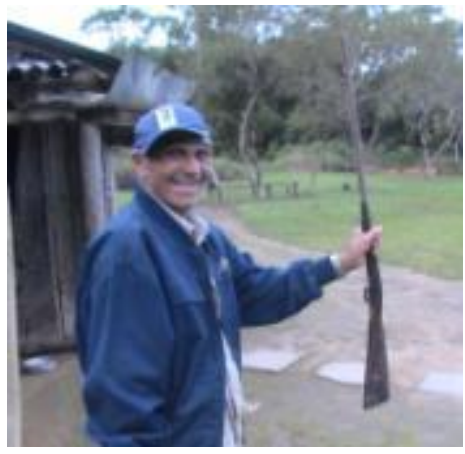

Figura 73: Seu Leonardo. Com uma espingarda encontrada na região. utensílios usados pelos soldados das tropas. Esses objetos são apresentados envolvendo histórias curiosas de espíritos de soldados e mulheres de branco que vagam pela região da Casa-de-pedra.

Seu Leonardo, que morava próximo ao lugar ${ }^{27}$, conta que "uma noite quando não conseguia dormir, ouviu seu cachorro começar a latir sem parar. Latia em direção a casa-de-pedra, mas não saia da porta da casa, como se estivesse com medo. Seu Leonardo olhou a escuridão da noite, lançou o facho da lanterna e não via nada, apenas ouvia o barulho da terra sendo cavada. Pensou que era algum bicho. Pela manhã, quando foi ver, encontrou no local um buraco aberto, com uma tigela virada de boca para baixo". Para Seu Leonardo a tigela estava cheia de ouro e a pessoa que desenterrou levou todo o ouro embora.

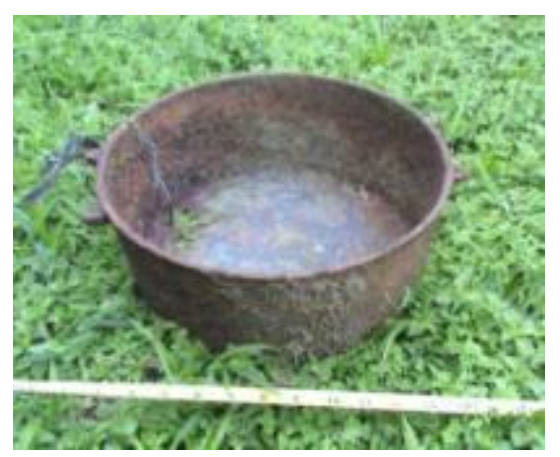

Figura 72: Tigela de metal encontrada por Seu Leonardo.

\footnotetext{
${ }^{27}$ Seu Leonardo mora atualmente atrás da escola, próximo à estrada municipal Colônia Santa Maria Mandira que corta o território Mandira. Ele chegou no Mandira como caseiro do atual proprietário das terras e até hoje exerce essa função. Entretanto, sua filha é casada com um mandirense e a família de seu Leonardo é considerada da comunidade Mandira, participando das festas, ajudando nos eventos e compartilhando das histórias e memórias.
} 
Até hoje ele guarda a tigela e exibe como a prova de sua história.

\title{
4.1.3 O Abacateiro/ O Sambaqui/ 0 dilúvio.
}

Outro lugar muito significativo na paisagem cultural do quilombo Mandira é a região localizada entre a trilha do Porto-de-fora e o rio Mandira, denominada entre eles de Abacateiro (ver mapas no Anexo 1). Contam que:

\begin{abstract}
"no tempo dos escravos, existia um negro valente que não gostava do cativeiro. Certo dia, cansado das crueldades do capataz, ele surpreendeu o feitor e bateu-lhe muito até quase matá-lo. Como repressão, o senhor da fazenda matou esse negro e mandou enterrá-lo próximo a sede da fazenda, plantando um pé de laranja em cima da cova. Dizem que essa laranjeira estava sempre carregada de frutas, mas nunca ninguém comeu nem uma laranja desse pé”.
\end{abstract}

Hoje o pé de laranja não existe mais, mas a história permanece ativa na memória dos Mandira. As interdições com relação aos frutos do pé de laranja, como ato de preservação, indica o modo de apropriação desse elemento da paisagem, significado como marco de resistência. No processo de significância desse marco, a região do Abacateiro adquire status de lugar patrimonial da resistência escrava. O lugar ficou marcado como símbolo da trajetória histórica de resistência impressa no Território Quilombola dos Mandira.

Nesse mesmo lugar encontramos também um dos mais antigos sítios arqueológicos presentes no Território: o sambaqui Mandira (UTM 22J 0796710/ 7231163). Trata-se de um sítio arqueológico bem conhecido pelos Mandira, mas que ainda não possui estudos sistemáticos. Pelas informações coletadas, grande parte do sambaqui foi removida quando ocorreu a ampliação da Trilha do Porto-de-fora, na década de 1970. A FOSFASA (antiga empresa

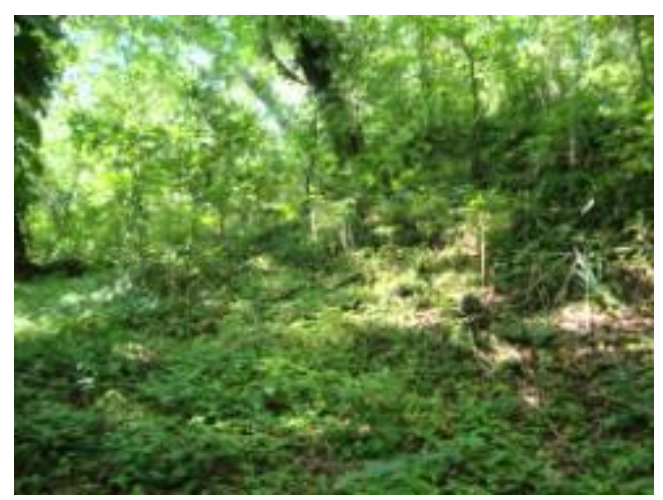

Figura 74: Sambaqui do Mandira. 
de Fomento Industrial e Fertilizantes S/A), com a intenção de lotear o local para fins comerciais ampliou a Trilha do Porto-de-fora, cortando parte do sambaqui e utilizando suas conchas como material para pavimentação.

Alguns moradores do Mandira trabalharam para a Fosfasa e participaram da obra de ampliação da trilha do Porto-de-fora. Contam que quando abriram a trilha e cortaram parte do sambaqui, encontraram mandíbulas e outros ossos humanos. Questionados sobre a procedência destes ossos, afirmam ser dos antigos moradores da região, as pessoas que habitavam esse espaço antes de ocorrer o dilúvio que ocasionou a formação do Sambaqui.

Para eles, o sambaqui é a prova do "dilúvio do Mandira". Segundo seu Chico, este evento aconteceu realmente e está relatado em um livro histórico da região ${ }^{28}$, apresentado pelo falecido padre de Cananéia, Padre Jan Van Der Heijden, mais conhecido como Padre João 30. Seus livros se encontram em posse de sua antiga secretária, Dona Maria Aparecida Ranjel, que disse ter conhecimento do evento do dilúvio. Dona Cida (como é chamada) compara o evento com as enchentes e deslocamento de terras que castigaram o interior do estado do Rio de Janeiro em 2010, a cidade de São Luiz do Paraitinga em 2009 e o Vale do Itajaí em 2008 e 2011.

Em muitas cosmologias ameríndias e africanas encontramos mitos sobre dilúvios e inundações (SCHADEN, 1953; SILVA, 2002; LIMA, 1972). Mesquitela Lima, antropólogo nascido em Cabo Verde, realizou em 1972, quando era diretor do Museu de Angola, um estudo comparativo entre alguns mitos etiológicos sobre a origem da formação de lagos e lagoas de Angola e o texto bíblico do dilúvio. O resultado dessa pesquisa é uma completa semelhança na morfologia estrutural das narrativas apresentadas. Todas as narrativas descrevem uma situação inicial de desordem; um segundo momento onde as narrativas apresentam três eventos em ordens diversas: a catástrofe pelo dilúvio, a punição dos maus e a salvação dos bons; e por fim a transformação com o desaparecimento dos maus e a presença dos bons (LIMA, 1972).

Nosso trabalho com os Mandira não permitiu um maior aprofundamento na cosmologia desse grupo. Entretanto, é inevitável perceber como o evento de um dilúvio faz parte da história de formação do Território. A forma como explicam a presença de conchas e ossos humanos na morfologia do sambaqui - associados ao evento do dilúvio que "limpou” os antigos habitantes e alguns resíduos da superfície da região, deixando o

\footnotetext{
28 Trata-se do livro de Paulino de Almeida "Memórias Memoráveis de Cananéia", publicado
} originalmente na Revista do Arquivo Municipal, out-dez, ano XV. Vol. CXX, pp. 3-28, 1948. 
local livre para os Mandira ocupá-lo - apresenta semelhança surpreendente com a estrutura formal das narrativas angolanas expostas por Mesquitela Lima.

Portanto, assim como nós arqueólogos não nos surpreendemos com esse tipo de interpretação, pois quem já trabalhou em áreas com sambaqui sabe que essa explicação é popularmente difundida, Seu Francisco também não se abala com as interpretações científicas sobre o sambaqui. Ele sabe que os cientistas acham que o sambaqui foi feito pelos índios pré-históricos, utilizando conchas e terra, para ser um cemitério. Mas para ele essa interpretação não explica o "dilúvio do Mandira”. Fato real dos Mandira, contado de geração em geração e documentado em livros, o dilúvio é explicado pela presença do sambaqui na parte mais baixa do terreno, em uma área facilmente alagada em época de chuva, para onde teria escoado a água.

Segundo o mapa do levantamento topográfico realizado no Sambaqui pelo ITESP (imagem 02 no anexo) e prospecções não interventivas realizadas no sítio, verificamos que seu formato original foi alterado. Todo seu flanco norte permanece preservado, entretanto, o flanco sul está comprometido, com parte de sua estrutura removida na ocasião da ampliação da trilha, acima referida. Contudo, nota-se uma elevação de forma arredondada, em formato monticular, de aproximadamente $10 \mathrm{~m}$ de altura, com uma base, estimada, de 46x60 metros. É composto por conchas de diferentes espécies, com aparente predomínio das ostras (Ostrea sp.), conchas de berbigão (Anomalocardia brasiliana) e de alguns gastrópodes terrestres (Megalobolimus ). Além das conchas, como vimos pelos relatos dos Mandira é possível que sepultamentos façam parte de sua constituição. Da mesma forma, louças e outros vestígios de ocupação histórica são encontrados em superfície (falaremos desses vestígios mais a diante).

\subsubsection{A Camboa/ 0 Caratuba/ Os Sambaquis.}

Outros três sambaquis localizados no fim da trilha do Porto-de-fora, depois da ponte do rio Caratuba (ou seja, fora da área do território Mandira), também foram atingidos pelo empreendimento da Fosfasa. Em 1984, o pesquisador Caio Del Rio Garcia do Instituto de Pré-História da Universidade de São Paulo, que realizava o levantamento dos sambaquis da região, solicitou perante o CONDEPHAAT o tombamento da área dos três sambaquis situados no lote $27 \mathrm{~B}$ do loteamento, para a preservação das “jazidas pré-históricas”. Tal solicitação foi aprovada pelo parecer da Conselheira Dorath Pinto Uchoa, do CONDEPHAAT e, após os trâmites legais, foi 
decretado (perante resolução 30 publicada no Diário Oficial, em 22 de agosto de 1987) 26,50 alqueires de terras de área tombada, no local onde se encontram os três sambaquis. Diante da impossibilidade de explorar os recursos do Sambaqui e seu entorno, a empresa desistiu do projeto de loteamento da área.

Toda a área dos três sambaquis tombada encontra-se na margem sul do rio Caratuba, ou seja, fora do território Mandira (ver mapas no Anexo 1). Por ser propriedade privada fomos impedidos pelo encarregado, senhor Júlio Souza, de chegar à área.

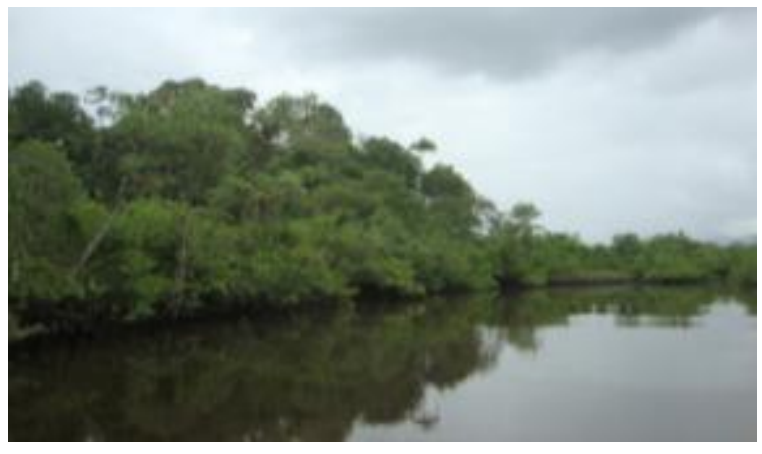

Figura 76: Sambaqui da Camboa em destaque na paisagem.
Ainda no território Mandira encontramos outro sambaqui na região da Camboa, próximo a Barra do Mandira (UTM 22J 0798543/ 7229185). O entorno do sambaqui era habitado por uma família de caiçaras que viviam da roça, da pesca, da caça e da criação de animais. Hoje em dia o lugar não é habitado, mas os Mandira reconhecem como lugar bom pra apanhar tatu. Entre os Mandira existe a relação entre sambaqui e tatu. Dizem que os tatus gostam de fazer tocas nos sambaquis, por serem lugares que não alagam. Por isso, onde tem sambaqui é lugar bom pra pegar tatu.

O Sambaqui da Camboa aparenta maior integridade em relação ao sambaqui do Mandira, no entanto, nenhum tipo de estudo sistemático ali foi efetuado, mesmo seu cadastro permanece inédito para na literatura arqueológica. Em nosso estudo

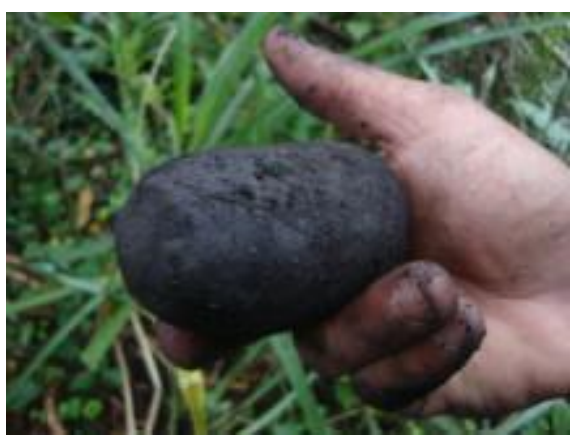

Figura 75: Pilão encontrado no sambaqui Camboa. apenas um caminhamento oportunístico foi realizado no intuito de reconhecer o sítio,

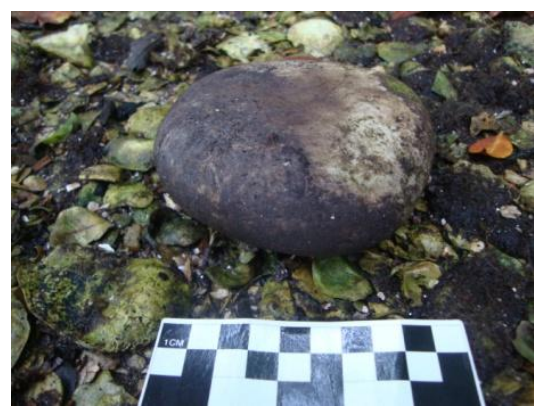

Figura 77: Objeto lítico encontrado, provável quebracoquinho. tomando as coordenadas geográficas com auxilio de GPS, o registro fotográfico de sua localização na paisagem e de alguns materiais encontrados em superfície. Com esses dados realizamos o cadastro do sítio no CNSA/IPHAN, conforme Anexo 4. 
Também trata-se de um sambaqui em formato monticular de aproximadamente $10 \mathrm{~m}$ de altura, não sendo possível nesse momento

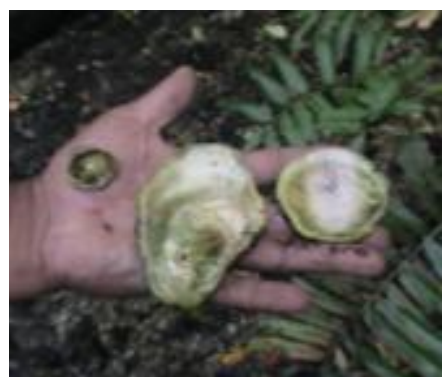

Figura 78: Espécies de conchas. estimar as dimensões de sua base. Os caminhamentos no sítio indicam um sambaqui sem cerâmica e sem vestígio de ocupações recentes. Por outro lado, batedores, percutores, manos, pilões e

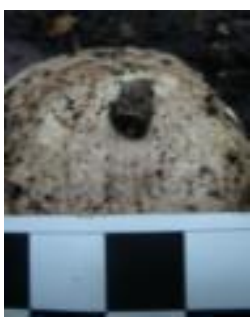

Figura 79: Fragmento de osso de peixe. quebra-coquinhos em diferentes matérias-primas líticas são encontrados com bastante frequência por toda superfície e entorno do sítio. Igualmente verificado no sambaqui do Mandira, este sambaqui é composto por conchas de diferentes espécies, com predomínio das ostras (Ostrea sp.), conchas de berbigão (Anomalocardia brasiliana) e, neste caso, ostras decimétricas são bastante frequentes. Outros restos faunísticos fizeram parte dessa estrutura, atestado por fragmentos de ossos de peixes ali dispersos pela superfície.

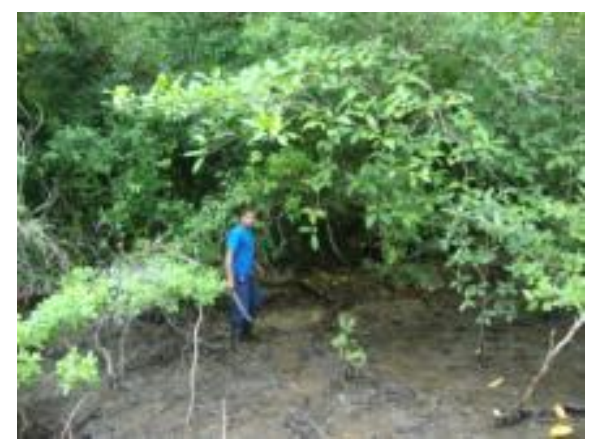

Figura 80: Nei Mandira na base exposta do sambaqui.

Localizado próximo a Barra do rio Mandira, em frente ao Mar-de-dentro e distante alguns metros das áreas de ocupação históricas não foram detectados cortes ou evidências de desmontes na estrutura desse sambaqui ocasionados pela ação humana. Entretanto, banhado pelo rio Camboa, a erosão fluvial tem intensamente retrabalhado sua base e flanco nordeste. $\mathrm{O}$ desgaste pela constância do movimento da maré expõe camadas sobrepostas de diferentes constituições, resultando em uma sequencia estratigráfica complexa. Contudo, apenas um estudo sistemático nesse sítio pode de fato revelar sua composição, suas sequencias estratigráficas, datações e processos formativos ali envolvidos.

Segundo Uchôa e Garcia (1983), ao longo do Baixo Vale do Ribeira podemos encontrar mais de uma centena de sambaquis. As pesquisas de Neves \& Okumura (2005) sobre a existência de afinidades biológicas entre indivíduos provenientes de sambaquis fluviais do rio Ribeira, datados do início do Holoceno, com indivíduos dos sambaquis da costa sul do estado de São Paulo, confluindo com semelhanças da cultura material e da própria forma estrutural de ocupação pela acumulação de conchas suporta a hipótese do Vale do Ribeira ter sido um corredor facilitador do fluxo gênico das 
populações do planalto ao litoral. Segundo essa análise, a região do Baixo Vale teria sido, então, o local a ter recebido os primeiros habitantes da costa sul e sudeste brasileira: os sambaquieiros.

Em estudo recente, Flávio Calippo (2010) estabelece um modelo de ocupação da sociedade sambaquieira no litoral do Estado de São Paulo, tendo em vista alguns fatores, entre estes a variação da linha costeira. Baseado nos estudos sobre sambaquis, nos estudos geomorfológicos e nos batímetros do fundo marinho que indicam algumas paleovales, paleoáreas estuarinas, paleolinha costeira de praias ainda estruturadas em áreas do Oceano, este pesquisador apontou locais e momentos históricos nos quais foram formadas as condições de maior potencial de preservação dos sítios e formação de grandes corpos lagunares e ambientes marinhos protegidos, ideais para o estabelecimento de um modo de vida sambaquieiro.

Para a região de Cananéia, este modelo de ocupação humana indica que os sambaquis podem ser relativos há pelo menos, dois momentos: 1) no primeiro momento evidencia-se o conjunto de sambaquis construídos nas partes mais altas do relevo de Cananéia, denominados "Sambaquis da Fase Transgressiva II", referente ao período entre 8 mil e 5.100 anos AP., quando se processava a elevação do nível do mar na região; 2) no segundo momento, o conjunto de sambaquis evidenciados parece ter sua distribuição espacial associada ao rebaixamento do nível do mar, iniciado após 5.100 ano AP., conjunto denominado "Sambaquis da Fase Regressiva" (CALIPPO, 2010:8284). Estudos arqueológicos sistemáticos nesses sítios devem contribuir para clarificar questões como essas e fornecer mais subsídios interpretativos sobre o histórico de ocupação do Baixo Vale do Ribeira.

\subsubsection{Palimpsesto na paisagem do Território.}

Esses diferentes momentos históricos que configuram a longa duração do território Mandira são perceptíveis no registro arqueológico. O sambaqui do Abacateiro, talvez por ser mais fácil o acesso por terra, vem sendo desconfigurado durante os sucessivos momentos de ocupações na área. Sobre seu flanco sul, a porção mais afetada, encontramos estruturas de ocupação histórica (UTM 22J 0796703/7231145). Trata-se de uma estrutura remanescente de paredes construídas com a mesma técnica de construção do engenho de arroz. Não se sabe se essa estrutura possuía a mesma dimensão arquitetônica do engenho. Conforme informaram alguns moradores do 
Mandira, o local abrigou a casa de Florêncio de Andrade. Isso pode ser possível já que em cima do sambaqui pode ser considerado um bom lugar para se morar, por causa da excelente compactação do solo, boa drenagem d'água da chuva e proximidade com o rio.

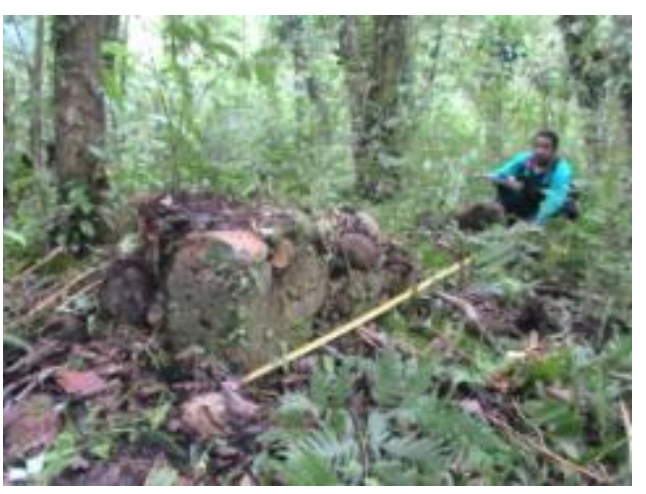

Figura 81: Vestígio de construção de pedra em cima do sambaqui.
Vestígios de paredes são visíveis no meio da vegetação rasteira, apresentando duas estruturas associadas: uma de $5,5 \mathrm{~m}$. e outra de 3,8 m., com 40 centímetros de largura cada. $\mathrm{O}$ conjunto das estruturas apresenta um espaço de 20 metros quadrados, o que pode ser apenas um cômodo da construção original. Entretanto, todas essas estruturas encontram-se em processo perecível, cobertos pelo mato. Os Mandira contam que essa estrutura de pedra terminou de ser derrubada quando tiveram que utilizar os materiais do sambaqui no alargamento da estrada do Porto em consequência do empreendimento da FOSFASA.

A relação da estrutura de pedra em cima de uma das partes do sambaqui cortado por uma trilha imprime na paisagem os diferentes momentos de ocupação do território Mandira. A composição dos diferentes vestígios arqueológicos no mesmo lugar evidencia o palimpsesto de ocupação impresso na paisagem. Além disso, segundo indicam alguns traços no vestígio arqueológico do sítio histórico, o palimpsesto nessa paisagem foi formado por um processo de reutilização, e - por que não - de ressignificação dos materiais e estruturas de outros vestígios arqueológicos, tendo em vista novas demandas e configurações sociais e talvez naturais.

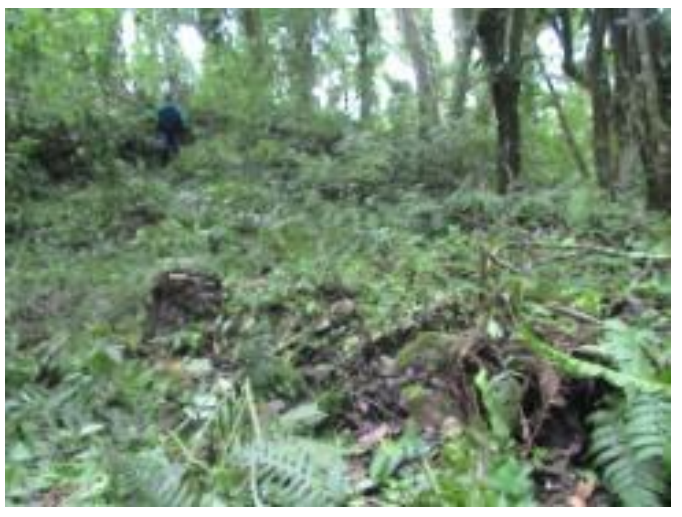

Figura 82: Palimpsesto evidenciado na paisagem: estrutura de ocupação histórica sobre o sambaqui.

Assim, pelo que consta, o sítio pré-histórico foi utilizado como fonte de matéria prima para a formação da estrutura histórica de ocupação; rente a ambos passa a trilha utilizada pelos antigos, conforme contam os Mandira. Ampliada na década de 1980 essa trilha vem sendo utilizada até os dias de hoje. Resta então realizar uma pesquisa 
arqueológica para investigar com mais precisão cada vestígio que compõe este palimpsesto, a fim de responder algumas perguntas como, por exemplo, saber quando foi feito cada traço na paisagem e com qual finalidade. Por esse tipo de intervenção científica sobre o patrimônio arqueológico será possível aprofundar ainda mais o conhecimento do dinâmico comportamento humano e das mudanças ambientais na longa duração; o que permite ainda pensar na reutilização e ressignificação do registro arqueológico (PANJA, 2004:112) evidenciado no processo de formação do Território Mandira.

\subsubsection{A Barra do rio/ Os estaleiros/ 0 dilúvio.}

Próximo ao Sambaqui da Camboa encontramos algumas toras de madeira distribuídas ao longo de toda a Barra do Rio. As toras medem aproximadamente quatro metros de comprimento, sessenta centímetros de espessura e cinquenta de largura. Encontram-se imersas no lodo do mangue na maré alta e surgem quando com a maré baixa. Todas cobertas de moluscos, mas em bom estado de preservação devido à intensa umidade. As toras de madeira encontram-se estrategicamente posicionadas na entrada do mangue, ao longo de toda a Barra do Rio, em locais de fácil acesso

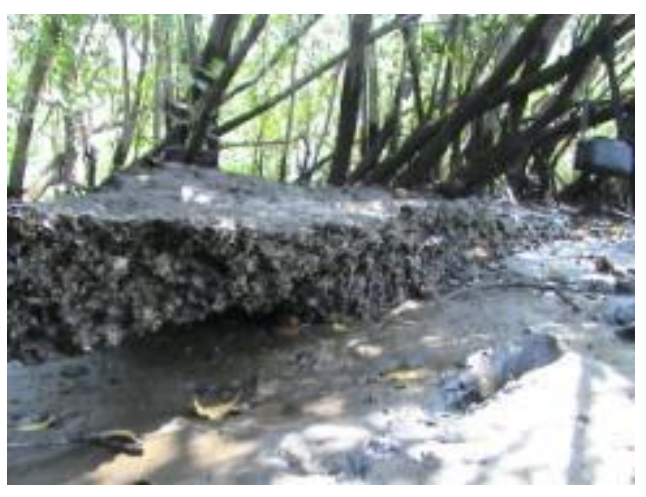

Figura 83: Toras de madeira no mangue. para quem chega pelo Mar-de-dentro.

Sabe-se que no fim do século XVIII e início do século XIX, Cananéia possuiu um grande número de estaleiros que deixaram vestígios em alguns pontos do município. Além do principal estaleiro de Cananéia, localizado onde hoje se encontra o prédio do Instituto Oceonográfico da $\mathrm{USP}^{29}$, Calixto (1895) cita a existência de outros quatro estaleiros no município: um no rio Taquari, outro no rio Itapitangui, outro no porto da Aldeia e um quarto na porção continental de frente a porção norte da Ilha.

Durante este período, os navios e barcos representavam um dos principais produtos de exportação na Vila de São João Batista de Cananéia. Por ser grande a

${ }^{29}$ Bava de Camargo (2009) escavou durante sua pesquisa de doutorado realizada no Museu de Arqueologia e Etnologia da USP e intitulada "Arqueologia de uma cidade portuária: Cananéia século $X I X-X X$ ", o estaleiro do porto urbano de Cananéia, onde hoje se encontra o Instituto Oceanográfico da USP. Além disso, também registrou a localização do estaleiro do rio Taquari. 
comercialização e a riqueza gerada, os donos de estaleiros também eram grandes proprietários de terras e de escravos (LUCCOK, 1975:403). Alem disso, todas as embarcações dessa época eram construídas predominantemente com o uso da madeira. Desde as pequenas canoas de pesca até os grandes barcos utilizavam a madeira como matéria-prima, sendo diferenciado a aplicação da tecnologia de construção. Não se sabe exatamente qual a procedência das madeiras utilizadas nos estaleiros. Como não existia qualquer fiscalização ambiental, se supõe que fossem madeiras provenientes da propriedade do próprio dono do estaleiro e das fazendas vizinhas.

A madeira é um material higroscópico, ou seja, troca vapor de águas com o ar dependendo das condições do ambiente. Quando a umidade relativa do ambiente é alta a madeira absorve ar e quando o ambiente está seco a madeira perde ar. Por isso, as madeiras usadas para a fabricação de barcos passavam por um período de inchaço, durante o qual ficavam submersos na água. Sendo assim, baseado nesses dados e na localização e posicionamento dos troncos de madeiras na Barra do Rio - local de fácil acesso tanto para a Barra-do-Itapitangui, a leste, quanto para a Barra-do-Taquari, a sudoeste - fica fortalecida a hipótese de que essas estruturas de madeira poderiam estar associadas ao processo de fabricação de barcos e navios nos estaleiros de Cananéia, no fim do século XVIII e início do século XIX.

Entretanto, para os Mandira, as estruturas de madeira enterradas no lodo do mangue (fotos 74 e 75) também são resultado do evento do dilúvio. Seu Chico sabe que não se trata de madeiras do mangue. Para ele, essas madeiras são do morro e foram parar no mangue depois do dilúvio. Quando questionado se essas madeiras são do mesmo dilúvio que formou o sambaqui, Seu Chico diz que não, pois aconteceram mais de um dilúvio no Mandira.

Se retornarmos ao livro "Memórias Memoráveis", onde o historiador de Cananéia, Paulino de Almeida, publicou suas pesquisas realizadas no Arquivo Municipal sobre os relatos presentes no documento "Memórias da Câmara da Vila de São João Batista de Cananéia", veremos que, segundo esse autor, alguns dos relatos já haviam sido publicados no ano de 1882 pelo pequeno semanário de José Inácio de Figueiredo, a Gazeta de Cananéia. Trata-se de diversas narrativas que descrevem o cotidiano em um ambiente repleto de figuras fabulosas e acontecimentos inusitados. Em uma dessas narrativas encontramos na data de 26 de julho de 1754 o relato de "rigorosas tempestades" (...) "Tanto sentiram os montes os açoites desta nova tempestade, que amanheceram com partes cortadas da violência do seu bater. Não 
menos sentidos ficaram os vales, que por muitos dias ficaram alagados". Ainda em outra narrativa datada de 25 de março de 1795, a referência ao Mandira é mais específica:

"No rio Mandira, em cujas margens estava a fazenda do Sargento-mór de ordenança Manoel José de Jesus, a enxurrada foi de maior altura, atingindo 14 côvados ou 42 palmos. O barro diluído e lançado por este rio atingiu o comprimento de cinco léguas e largura de meia quarta de légua de seu maior oriental, cobrindo as praias com nova camada de lama; foram destruidas as casas e coberto o solo pelo saibro, deixando, por isso, apenas o nome da fazenda sepultada”.

\subsubsection{Rio Penico/As areias / As taperas.}

À oeste da região do abacateiro, bem próximo ao sambaqui, encontramos o rio Penico que se configura como outro elemento da paisagem que marca o território quilombola dos Mandira pelas histórias associadas às mulheres. Eles lembram que os homens, na época da fazenda de escravos, faziam suas necessidades no mato ou nos rios. Mas as mulheres pelo comportamento mais recatado faziam suas necessidades em penicos e depois lançavam os dejetos nesse rio, lavando a louça no local. A partir daí se justifica o nome do Rio Penico. Hoje em dia a região está toda ocupada pela densa mata tropical. Entretanto, a toponímia indica que as áreas próximas ao rio Penico foram possíveis áreas de moradia dos Mandira.

Questionada sobre o local de moradia dos Mandira, Dona Saturnina conta que as casas eram todas espalhadas no meio do mato. "As casas não ficavam juntas como são hoje, naquela época eram todas espalhadas. As vezes tinha a casa do filho perto da do pai, mas ficava tudo espalhado”. São muitas as áreas de moradia relatadas nas histórias dos Mandira. Em todos os lugares prospectados durante o projeto foi evidenciado os sinais nas paisagens descritos pelas narrativas e vestígios de materiais construtivos e objetos domésticos dispersos ao longo de uma topografia plana e extensa (variando entre 150 à $500 \mathrm{~m}^{2}$ ). 


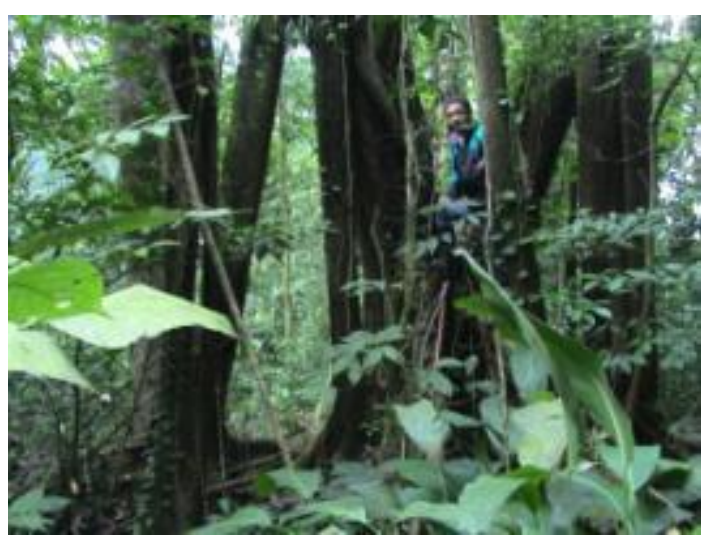

Figura 85: Figueira sinaliza local da tapera.

Na região próxima a casa-de-pedra, na baixa vertente do morro foram encontrados vestígios da tapera do Dito, pai do Vardo (UTM 22J 796056/ 7231691). O local apresenta um terraço na baixa vertente do morro, com materiais dispersos próximos a uma figueira. Vardo relata que nasceu e viveu até os cinco anos de idade nessa tapera. O único sinal que se recorda é o pé de figueira que ficava próximo à casa. Ele lembra também que existiam outras casas no entorno, aproximadamente há cem metros de distância. No local foi encontrada uma garrafa de gargalo com coloração verde, um chinelo havaiana de criança, uma xícara de louça e materiais construtivos como telha e

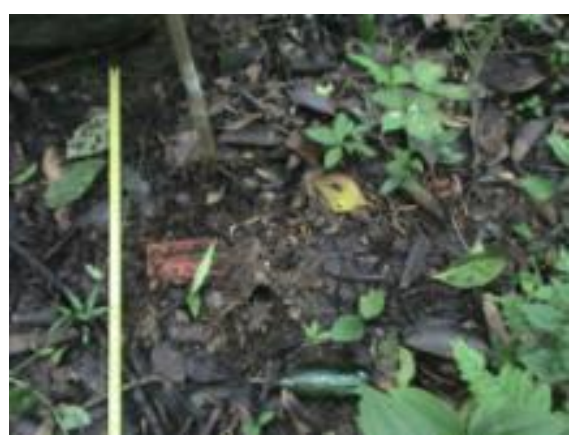

tijolo, provavelmente artesanal por não apresentarem a sigla do fabricante gravada.

Próximo, outra tapera foi localizada em um platô (UTM 22J 0796124/ 7231694) de aproximadamente cem metros quadrados de extensão, com uma grande pedra de granito em uma das extremidades. No local foram evidenciados Figura 86: Vestígios da tapera. objetos domésticos, como uma pequena panela de metal esmaltada branca e um suporte metálico bem oxidado de formato retangular, apresentando uma asa como aparador. Luis, filho de Seu Chico, participou da prospecção e apontou o local como antiga moradia do Seu Floriano.

Para oeste da casa-de-pedra, próximo a região denominada Grota Funda, foi encontrada a tapera do Seu Frederico, rente a atual estrada que corta o território Mandira. No local (UTM 22J 796709/ 7231996) foram evidenciados materiais construtivos recentes, como tijolos baianos dispersos e objetos domésticos como lata de óleo, garrafa de vidro lisa de formato convencional, na coloração oliva e um pequeno penico de metal com coloração branca. 
Na margem esquerda do rio Mandira, na região da escola, foram localizadas três taperas, além de uma estrutura de concreto, segundo os Mandira correspondente a casa de um padre holandês que residiu no local. Além da presença do Luis, a prospecção nessa região também contou com a ajuda do Senhor Leonardo. Segundo ele, o local da casa do padre

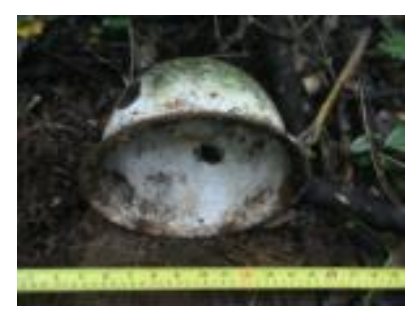

Figura 87: Penico. holandês (UTM 22J 0797366/ 7232437) é identificado por uma laje de concreto cumprida medindo mais de seis metros de comprimento por sessenta centímetros de largura e menos de dez centímetros de espessura, com buracos esféricos abertos que varam a laje de um lado a outro. Apesar das histórias vivenciadas pelo Seu Leonardo e confirmadas pelo Seu Chico e do terreno ser plano e extenso, nenhum outro vestígio é encontrado em superfície que confirme a área como de moradia.

Os Mandira contam que nesse lugar conhecido hoje como região da Escola existiu um padre holandês que ocupou uma porção do território por uma época. Consta que esse padre montou um orfanato onde hoje é a escola estadual e trazia crianças de Cananéia para viver com ele. O orfanato era de zinco e chegou a hospedar mais de trinta crianças. Mas dizem que o padre obrigava as crianças a trabalharem para ele, o que fazia muitos deles fugirem do orfanato. O padre não permaneceu muito na região, mas no lugar onde montou o orfanato abriga hoje a escola Estadual do Mandira, com aulas para alunos da pré-escola.

No sopé do morro, a primeira tapera Mandira encontrada foi habitada por

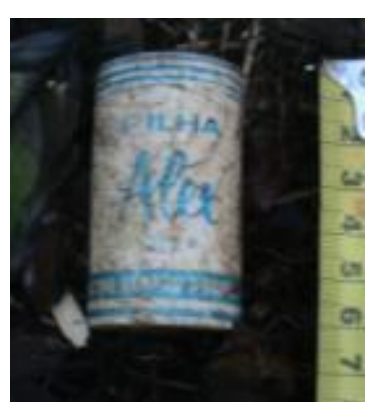

Figura 88: Pilha Alex. Amâncio Mandira, filho do Jango Mandira. No local (UTM 22J 797504/7232313) aparecem telhas de cerâmica recentes do tipo francesa e uma pilha "Alex" da Companhia Nacional de Pilhas, que data das décadas de 1960 e $1970^{30}$.

Rente a margem do rio Mandira, próximo a estrada (UTM 22J 797368/ 7232354) encontramos uma pequena estrutura provavelmente de fossa, sinalizando o possível local da tapera de Dona Zumira. A estrutura feita de concreto tem formato quadrado com pouco mais do que cinquenta centímetro de cada lado. Cavada mais do que trinta centímetros

\footnotetext{
${ }^{30}$ A Companhia Nacional de Pilhas inaugurou em 1955, uma fábrica de pilhas em Itapecirica, Minas Gerais. Aproveitando uma jazida de Manganês e carvão existente na região, a fábrica montava as Pilhas Alex, que ganharam o mercado nacional com seu aperfeiçoamento técnico, após 1960. Entretanto, a fábrica de pilhas foi fechada em 1973, depois que o diretor Alexandre Szundy foi afastado e a Pilha Alex parou de ser produzida.
} 
no chão, sua base afunila terminando em um pequeno buraco esférico, por onde os dejetos eram direcionados ao rio. A estrutura da fossa possui bordas quadrangulares que se sobressaem aproximadamente quinze centímetros da superfície. Nas proximidades da

mesma evidenciamos um aglomerado de fragmentos de telhas e tijolos amontoados. A personagem de Dona

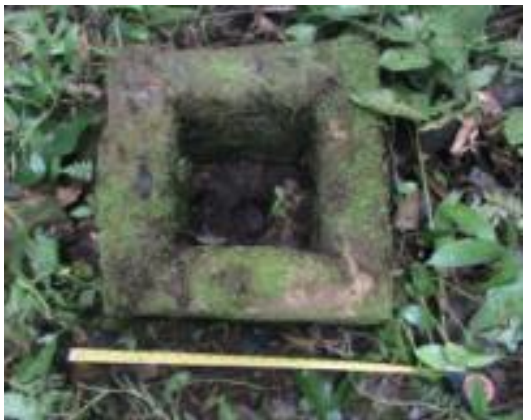

Figura 89: Fossa na tapera da Dona Zumira.

Zunira é conhecida entre os Mandira como a amante do Seu Jango.

A tapera do Seu Jango também foi localizada na região da escola, na margem esquerda do rio Mandira, antes da estrada (UTM 22J 797462/7232383). A referência que determina o local de tapera foi novamente a topografia plana do terreno associado a

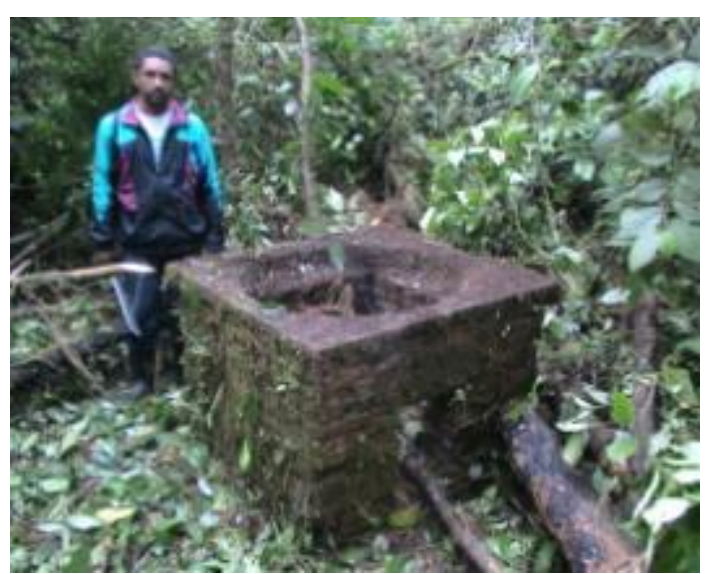

Figura 91: Luis, ao lado do forno da tapera do Seu Jango. evidência de materiais concentrados em torno de um forno. $\mathrm{O}$ forno quadrangular tem as paredes construídas de tijolos deitados, com noventa centímetros de altura e aproximadamente setenta centímetros de comprimento em cada lado. $\mathrm{Na}$ parte de cima encontra-se a boca do forno feito de concreto em formato circular, proporciona um suporte onde a taipa poderia ser apoiada. Na parte inferior de um dos lados existe uma abertura retangular, por onde o forno era alimentado de lenha e na outra parede existia a saída da fumaça por um cano grosso. No entorno do forno evidencia-se uma figueira (como marco paisagístico do local), alguns materiais construtivos, como tijolos, telhas e granitos recortados na forma de cubos retangulares e fragmentos de garrafas de vidro lisas de coloração oliva escuro.

Seguindo a margem esquerda do rio Mandira, no serpentear do seu caminho, após a estrada Itapitangui-Ariri, aproxima-se de um

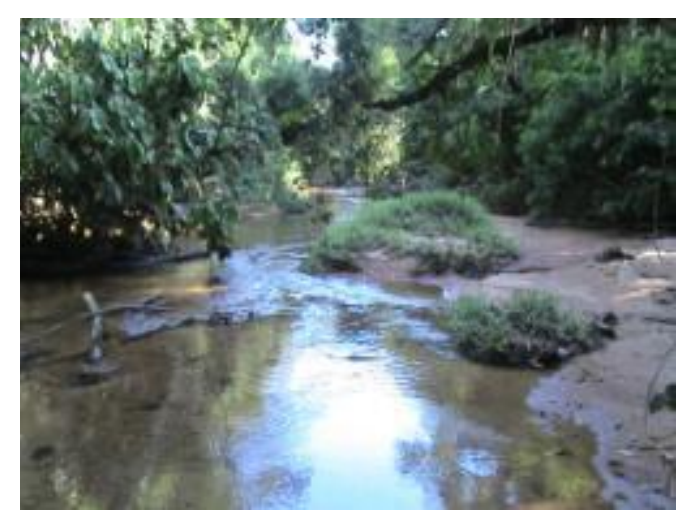

Figura 90: Rio Mandira na região das Areias. 
lugar chamado “As Areias”. O lugar é assim chamado por estar próximo ao meandro do rio Mandira onde a deposição de sedimentos formou um bolsão de areia em sua margem esquerda. Este lugar é lembrado pelos Mandira como o lugar onde se originou a família Mandira, com os filhos do Francisco Mandira. Segundo Dona Saturnina, seu avó, João Mandira, morou lá. Somente depois de sua morte seus filhos se mudaram para a trilha do Porto-de-fora, próximo ao sambaqui.

Os Mandira relatam pelas histórias que nesse lugar existiam muitas casas. Nos caminhamentos feitos ao longo da trilha das Areias foram evidenciados dois locais (UTM 22J 0797546/ 7231822 e 0797443/ 7231757) com concentração de materiais construtivos como pedras brutas de quartzo e granito com restos de conchas moídas nas bordas misturadas a uma resina endurecida. Também foram evidenciados materiais domésticos, como garrafão de vidro de cor oliva e frasco de vidro transparente para remédio, dispersos no chão. Os dois locais de terrenos planos localizados próximos ao rio e trilha com materiais em superfície comprovam que foram sítios de taperas.

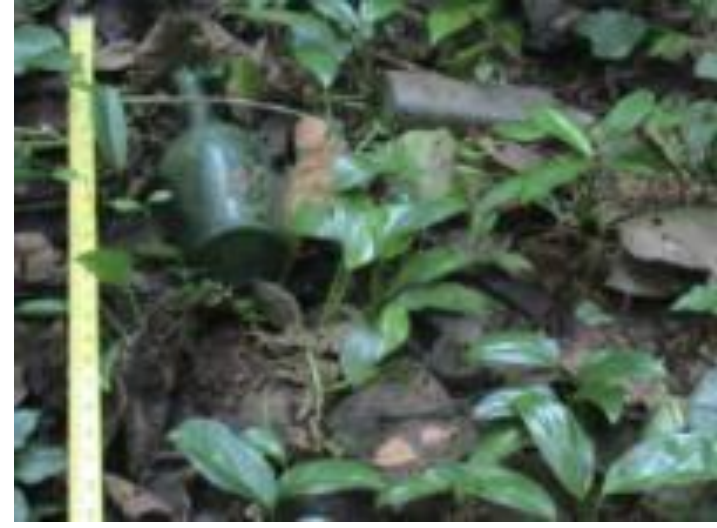

Figura 92: Objetos dispersos em superfície.

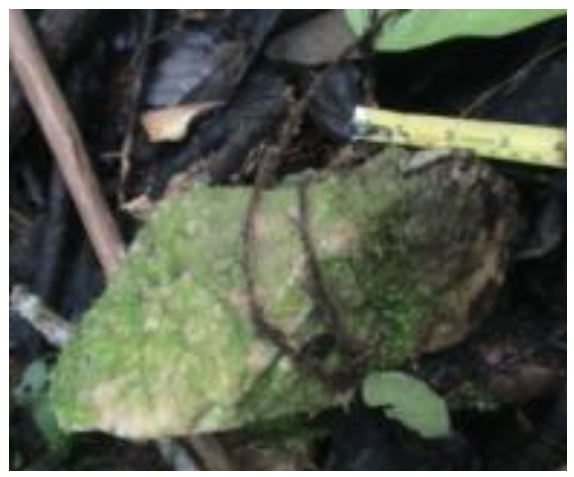

Figura 93: Pedra de quartzo com evidência de resina com conchas trituradas.

Seu Chico se lembra do antigo campo de futebol que existia nas Areias (UTM 22J 0797510/7231830). As narrativas tradicionais e as histórias orais apontam para esse ser o provável lugar de moradia dos escravos no tempo da fazenda dos Andrades. Não foram encontrados em superfície qualquer vestígios de estrutura de senzala ou objeto que remeta ao tempo da escravidão. Provavelmente, os escravos moravam em casas de pau-a-pique com telhado de palha, não deixando exposto muitos vestígios de sua construção. Algumas poucas estruturas construídas em pedra devem ter sido desmontadas após o abandono do local. O processo de abandono desse lugar e a transformação da paisagem do território após a doação das terras à Francisco Vicente 
fornece mais informações sobre a territorialidade Mandira relacionado aos lugares e suas histórias.

\subsection{A reformulação da paisagem.}

Pelo particular fato histórico dos Mandira terem sido segregados em suas próprias terras, nos últimos cinqüenta anos o Território Mandira sofreu uma brusca transformação. Com o processo de abandono forçado das antigas áreas dos núcleos de moradia, a população foi obrigada a ocupar apenas a porção de área do extremo leste do território. Assim, o que antes era um espaço totalmente ocupado, com lugares significativos, com memórias biográficas, hoje em dia boa parte se encontra abandonado, coberto pela mata, em nível avançado no processo de sucessão ecológica.

Por outro lado, onde antes era um espaço de passagem, sem muito significado, hoje é ocupado por núcleos de moradia, reproduzindo outros lugares significativos na continuidade histórica dos Mandira. Como podemos observar as áreas de atividade são criadas a partir do núcleo de habitação. Isso fica claro quando comparamos os mapas históricos com o mapa atual do território Mandira (ver mapas no Anexo 1).

Deste modo, vemos a parte sudoeste do território Mandira densamente ocupada na época da fazenda. A sede da casa dos Andrades estrategicamente situada entre o engenho de arroz e o porto, com seus escravos, entre eles Francisco Vicente e seus filhos, habitando a região das Areias e os carreadores e caminhos interligando as áreas de moradia, as roças e os portos da fazenda. Com o abandono da família Andrade e a doação das terras para Francisco Mandira, muitos dos ex-escravos devem ter deixado a região e outros transferiam-se para a sede da fazenda, ocupando a casa do antigo senhor. Segundo os relatos históricos de Dona Saturnina, a família de Francisco Vicente permaneceu na região das Areias até a morte de João Vicente Mandira. Só depois disso, a família se mudou para próximo da Trilha do Porto-de-fora e da região do Abacateiro.

Conforme a comunidade crescia outras áreas do território eram ocupadas. Eles contam que é dessa época as taperas no sopé do morro, na região da Casa-de-pedra. As pessoas escolhiam esse lugar por ser bom para plantar e ficar próximo a trilha do Portode-fora, tendo acesso fácil ao rio Mandira. A comunidade crescia em torno da trilha do 
Porto-de-fora e do rio Mandira, procurando ter acesso fácil tanto aos recursos da terra quanto do mar, além do transporte para outros lugares.

Essa região era muito ocupada quando as tropas da revolução de 1932 obrigaram as famílias a abandonarem a área e retornarem novamente às Areias. Contam que o período de guerra foi vivido intensamente pelos Mandira. Depois disso, muitos não voltaram e foram viver mais afastados da casa-de-pedra ou do Abacateiro. Novos núcleos de moradia se formaram no sopé do morro, próximo ao caminho do PC. Outros caminhos foram feitos, novas roças cultivadas e mais locais condicionados a portos para o uso diário.

A territorialidade Mandira continuava preservando seu território entre o ambiente do mangue e as terras dos morros próximos. Continuavam criando os lugares significativos nos canais, portos e mangues, assim como nos caminhos e carreadores. Desse período data a transferência de Jango Mandira, para a região próxima a atual Escola, onde era o orfanato do padre holandês. Jango havia começado a criar gado, por isso precisava de um lugar apropriado para transformar em pasto. Assim, quando o padre holandês fechou o orfanato e deixou a região, Jango se mudou com a família para esse local de áreas planas no sopé do morro.

Nessa mesma época, a família de Cristino Mandira estava vivendo na região denominada Baixa Grande, em frente ao caminho do cavalo, onde hoje é um dos núcleos de moradia do atual vilarejo. Próximo ao local foi montado uma carvoaria no início da década de 1960. Seu Cristino se associou a uma pessoa de Minas Gerais que habitava a região de Cananéia, para montar essa carvoaria. Entretanto, o negócio não prosperou e em pouco tempo a carvoaria foi abandonada. Da experiência só restou o local com os vestígios e os perfis dos fornos registrados no solo. Trata-se de uma área de aproximadamente $100 \mathrm{~m}^{2}$ (UTM 22J 0799014/ 7232267), onde foram encontrados oito perfis de forno no chão e na encosta do morro, todos cobertos pelo mato. Os perfis demonstram os fornos distribuídos de forma circular, medindo aproximadamente um metro de altura, com amontoados de tijolos. Alguns preservam a abertura rebaixada de abastecimento do forno.

Quando veio a ocorrer o fato da venda das terras, a família de seu Cristino já estava vivendo nesse local e lá permaneceu (hoje em dia Seu Zacarias, filho de Seu Cristino, vive com a família no mesmo lugar). Como se sabe, as outras famílias foram obrigadas a se transferirem para a região da Baixa Grande, onde hoje é a atual vila. Com 
isso, novos caminhos e carreadores foram abertos e novos portos foram estabelecidos. Já não podiam utilizar os recursos da terra, então só lhes restaram os recursos do mar.

Observando os mapas históricos e comparando-os com o mapa atual procuramos ilustrar o território Mandira com seus vestígios de ocupação em uma perspectiva temporal. Assim, podemos observar no mapa do Século XIX muitas áreas de atividades, os caminhos e portos reproduzidos a partir das áreas de moradia. No mapa da década de 1960 observamos novas áreas de atividade, como o cultivo de caixeta e a área de pasto. No entanto, a partir dessa data, as áreas do território foram limitadas, assim como as atividades nelas realizadas. Porém, os caminhos, portos, sítios arqueológicos e históricos continuam sendo um marco na paisagem do território, ao mesmo tempo em que outros lugares vão sendo (re)significados.

Como já foi mencionado, o vestígio de estrutura de pedra encontrada sobre o flanco sul do sambaqui terminou de ser destruída quando ampliaram a trilha do Portode-fora. Nessa época, os Mandira pouco conheciam sobre a importância do patrimônio cultural arqueológico do seu território e a identidade quilombola ainda não tinha reconhecimento social. Os Mandira viviam abandonados e rejeitados por serem pobres e negros.

Hoje em dia, eles preservam estes sítios arqueológicos como importante marco histórico para a sociedade brasileira e para a identidade quilombola. As ruínas servem como atrativo para a comunidade receber turistas e grupos de alunos de escolas particulares, para trabalharem com esses temas educativos e contribuirem para a economia local. Eles expõem o sítio arqueológico como prova material da longa existência histórica de seus ancestrais no que hoje chamam de território quilombola.

Os Mandira nunca deixaram de transitar por seu território. Mesmo sendo proibidos de utilizar os recursos de suas terras e ocupar livremente seu território, eles permanecem transitando pelos caminhos dos antigos e acessando os portos e canais. Apesar disso, a intensidade com que os lugares antigos são acessados mudou. Hoje em dia, eles ocupam mais as áreas próximas à vila. Isso inclui o porto de Boacica e o portoo Zé Abraão, assim como o caminho do Mato e dos portos. Desta forma, a territorialidade dos Mandira permaneceu sendo inventada, com novos lugares incorporados aos antigos modelos de ocupação do território. 


\section{ARQUEOLOGIA E PATRIMÔNIO QUILOMBOLA}

\subsection{A paisagem herdada.}

Como vimos, as comunidades quilombolas são formadas por agentes oriundos das mais variadas formas de exclusão social no Brasil, predominando aqueles da diáspora de escravos africanos. Sendo assim, os quilombos no Brasil são formados por povos que estabeleceram vínculos com a terra por diferentes processos históricos, em torno do fenômeno social da escravização imposto pela colonização portuguesa.

Baseando-se nos estudos arqueológicos dos sambaquis de Cananéia e região se pode inferir que as terras hoje conhecidas como território Mandira vem sendo ocupadas há pelo menos 3 mil anos por diferentes povos. Segundo Zedeño (2009), os vestígios arqueológicos resultantes das sucessivas ocupações no território, e os recursos deixados na terra por esses ocupantes da região, imprimem na paisagem sua relação com o ambiente. Os recursos ao serem utilizados e ressignificados pelos atuais ocupantes do território, configuram-se como heranças paisagísticas.

Nas palavras de Aziz Ab’Sabes (1977:3):

"a paisagem é sempre herança em todo o sentido da palavra: herança de processos fisiológicos e biológicos e patrimônio coletivo dos povos que historicamente as herdam como território de atuação de suas comunidades. Mais do que simples espaço territorial os povos herdam paisagens e ecologias, pelas quais certamente são responsáveis, mas todos têm uma parcela de responsabilidade permanente de uma herança única que é a paisagem terrestre."

No entanto, por meio do código florestal, o Estado brasileiro proíbe os Mandira e outros povos do entorno de ocuparem e explorarem os elementos de seus territórios segundo seus próprios saberes tradicionais. Vemos que a política conservacionista de restringir o modo de vida tradicional dos Mandira em seu território, em prol da demarcação da área como Patrimônio Ambiental do Estado que deve ser conservada longe da ação humana, é uma forma de reproduzir o que Diegues (2008) chama de "mito moderno da natureza intocada". 


\subsection{Contradição: A titulação como Área de Proteção Ambiental (APA).}

Boa parte do território Mandira foi, por muito tempo, demarcada como área do Parque Estadual de Jacupiranga. Segundo o decreto-lei 145 de 08 de agosto de 1969, toda antiga área dos núcleos de moradia onde se concentram os melhores recursos do território Mandira, assim como toda área acima do salto Mandira, tornou-se área de preservação permanente do Estado de São Paulo. Segundo o artigo $1^{\circ}$ do código florestal, isso quer dizer que essa área, com seus recursos, não pode ser utilizada ou explorada de forma alguma. Seu uso pode caracterizar-se como nocivo à propriedade, sujeito as penas previstas no Código de Processo Civil.

A criação desse tipo de parque, como reserva natural, remete a representação simbólica pela qual existiriam áreas naturais, intocáveis e intocadas pelo homem, apresentando componentes em um estado "puro". Definida por Carlos Diegues (2008:55) como "mito moderno da natureza intocada" essa ideologia supõe a incompatibilidade entre as ações de qualquer grupo humano e a conservação da natureza ${ }^{31}$.

Movido pela ideologia preservacionista, essa política pública do meio ambiente provoca o êxodo rural ao proibir os povos locais de viverem nas regiões onde sempre habitaram, e onde os estudos arqueológicos comprovam a existência de vestígio de ocupação humana de mais de 3 mil anos. Os costumes desses povos, que retiram da paisagem herdada os recursos para viver, são ignorados e suas tradições supostamente desconhecidas. O suposto desconhecimento das práticas e saberes ancestrais estão relacionados a duas formas de dominação: 1) a aplicação de paradigmas de uma ciência positivista e reducionista que se apresenta falsamente como neutra e verdadeira, fragmentando sua percepção e conhecimento; 2) a pressão dos centros urbanos sobre os territórios das populações minoritárias do campo e do litoral, transformando estas

\footnotetext{
31 Essa concepção, típica dos primeiros conservacionistas norte-americanos, pode ter suas origens na idealização do paraíso terrestre, próprio do Cristianismo, onde tudo era naturalmente perfeito e abundante antes do ser humano habitá-lo. No final do século XIX e primeira metade do século XX, ela foi muito difundida após a expansão colonialista para o oeste e o genocídio dos índios norte-americanos. Nesse período a urbanização era acelerada e se propunha, com o mapeamento e planejamento de ocupação do território nacional, subtrair grandes áreas da expansão agrícola, colocando-as à disposição das populações urbanas para fins recreativos. Esse modelo conservacionista se espalhou pelo mundo todo, recriando a dicotomia entre homem e natureza (DIEGUES, op.cit.:26).
} 
paisagens socialmente construídas e simbolicamente representadas em lugares de lazer e veraneio das diferentes classes sociais dos grandes centros industrializados (DIEGUES, 2008).

Com os movimentos ativistas que partiam da crítica à sociedade tecno-industrial no fim dos anos 1960, surgem novos conceitos ecológicos. A partir daí as questões ambientais passaram a ser bandeira de luta ao lado dos protestos contra o militarismo e a favor dos direitos das minorias sociais. Com a Conferência sobre Meio Ambiente e Desenvolvimento, realizada no Rio de Janeiro, em 1992, consolidou-se o conceito de desenvolvimento sustentável, de modo a conciliar as reivindicações dos defensores do desenvolvimento econômico, com os setores preocupados em conservar os ecossistemas e a biodiversidade.

O conceito de biodiversidade adquiriu largo uso no mundo todo, valorizado como fonte criadora e mantenedora da vida. Este conceito foi construído a partir da ideia de que um organismo vivo é um sistema aberto em constante interatividade com outros organismos. Por esse entendimento, quanto maior a biodiversidade (ou seja, maior a diversidade inter e intra-espécies e, comparativamente, entre ecossistemas) mais abundante será a vida no planeta (CAPRA, 1996). O desenvolvimento sustentável se resume, então, na ideia de gerenciar a biodiversidade nas e das paisagens, integrando os elementos da natureza e das práticas culturais.

Os Mandira podem ser vistos como um exemplo do modo de interação homemnatureza, historicamente estabelecido pelas populações que habitam o ambiente do Complexo Lagunar Iguape-Cananéia. Esses quilombolas, em particular, herdaram de seus antepassados a sabedoria local de não apenas preservar o meio, mas também explorá-lo de modo a obter maior variedade de espécies.

Segundo Diegues \& Nogara (2005), as proibições que recaem sobre as práticas culturais, estas embebidas em longos e profundos conhecimentos ecológicos através dos saberes e práticas tradicionais, têm impacto não somente sobre a intensidade do uso, mas também sobre as técnicas patrimoniais do saber-fazer que demonstram as estratégias da comunidade em manter uma elevada taxa de biodiversidade.

Este trabalho não explora o amplo campo do etnoconhecimento dos Mandira ${ }^{32}$. No entanto, é inevitável não comentar sobre o patrimônio imaterial na medida em que

\footnotetext{
${ }^{32}$ Para mais conhecimento sobre os etnoconhecimentos dos mandira e de outros povos de Cananéia ver Antônio Carlos Diegues, "Enciclopédia Caiçara Vols. I, II, III, IV e V"; Bianca Cruz Magdalena, "Reza a Lenda", Bianca C. Madalena \& Juliano Silva do Nascimento, "O uso de plantas medicinais por
} 
desenvolvemos um trabalho sobre a cultura material do território Mandira. Ambos conhecimentos envolvem um conjunto de saberes ancestrais que vêm sendo preservados enquanto patrimônio da comunidade quilombola, na mesma proporção em que os detentores desses saberes preservam os recursos da terra e o próprio território como patrimônio.

\subsection{A institucionalização da “Gestão do Patrimônio Arqueológico".}

A biodiversidade ainda é tecnicamente valorizada enquanto um produto da natureza, desvinculada do processo cultural de ocupação da humanidade. Isso é facilmente comprovado tendo em vista o tamanho dos parques nacionais como grandes áreas geográficas, enquanto os sítios de patrimônio cultural e territórios de povos tradicionais são pequenas áreas de ocupação. Apesar de existirem alguns parques arqueológicos de grande importância no mundo, os valores culturais continuam sendo vistos de importância secundária nesse processo.

No entanto, de alguma forma, isso tem começado a mudar nas últimas décadas e os valores culturais dos parques nacionais começam a ser reconhecidos. Novas nomenclaturas são criadas para estabelecer áreas de preservação ambiental onde é permitida a permanência dos antigos moradores. Terras indígenas e territórios quilombolas são demarcados por seu valor histórico-cultural, associados a modelos não agressivos de ocupação.

De acordo com Laurajane Smith (2006), foi após a "National Environment Policy Act" ou NEPA, editada no fim da década de 1960, nos Estados Unidos que a expressão “Cultural Resource Management” ou CRM se tornou amplamente conhecida. Com as crescentes opiniões da época sobre a conservação tanto do patrimônio natural quanto cultural, os arqueólogos também começaram a engrossar as vozes pela conservação dos recursos arqueológicos. Arqueólogos dos EUA, UK e Austrália agitaram as décadas de 1960 e 1970 com propostas para a preservação e proteção dos

comunidades tradicionais caiçaras de Cananéia", Cleber Rocha Chiquinho, "Saberes Caiçaras: A cultura caiçara na história de Cananéia", entre outros. Ver referência completa na bibliografia. 
recursos arqueológicos e o desenvolvimento de legislações governamentais que protegessem tanto o patrimônio cultural indígena quanto não indígena ${ }^{33}$.

As mesmas décadas foram marcadas na arqueologia pela "perda da inocência" (CLARKE, 1973). A Arqueologia começou a desenvolver abordagens teóricas voltadas à busca pelos princípios gerais do comportamento humano. A pesquisa arqueológica procurava ser mais explícita e científica, estabelecendo-se firmemente como uma ciência de métodos rigorosos e sistemáticos, com modelos inspirados nas ciências exatas. Calcando-se em pressupostos teóricos do funcionalismo, neo-evolucionismo e ecologia cultural, definiu-se um novo rumo das pesquisas arqueológicas, inaugurando a chamada Nova Arqueologia.

Esse debate ajudou a reforçar a proclamação da arqueologia como uma disciplina e prática intelectual dotada de legitimidade científica. Segundo Smith (2008:68), os direitos da arqueologia como uma ciência de dados, na concepção de ciência como conhecimento universal, reforça a autoridade da intelectualidade arqueológica frente às demandas do patrimônio cultural. A legitimação da arqueologia como ciência, pela Nova Arqueologia ocorreu junto com a concernência cada vez maior do Estado quanto ao patrimônio cultural. A maior consequência desse fenômeno foi a institucionalização da ciência arqueológica no aparato estatal como discurso responsável pelo gerenciamento do patrimônio cultural.

Essa estrutura do discurso patrimonial é denominada por Smith (2006) como Authorised Heritage Discourse (AHD). Para a autora esse discurso é construído tomando como referência a materialidade do patrimônio que passa a ser entendido como coisa e como uma herança que pertence a toda a humanidade. "O sentido de que herança (leia-se patrimônio) é entendido como coisa é também reforçado pela naturalização das apropriações arqueológicas a respeito da herança (leia-se patrimônio) nos instrumentos legais e políticos" (SMITH \& WALTERTON, 2011:43). É isso que legitima as ações de gestão do patrimônio a partir de uma percepção universal.

Alguns autores que refletem sobre essa perspectiva naturalizante do patrimônio chamam a atenção para sua agência, por considerarem que as relações sociais não se

\footnotetext{
${ }^{33}$ O termo "Gestão de Recursos Culturais, cunhado inicialmente, foi gradualmente sendo substituído por "Gestão de Patrimônio Cultural". Segundo Heather Burke \& Claire Smith (2010:29) essa mudança terminológica respondeu a críticas de povos aborígenes, que argumentavam contra a ideia de cultura ser associada a concepção de recurso. Para eles recurso significa algo passivo de exploração ou salvamento, com conotação universal. Patrimônio, por sua vez reconhece a relação de herança cultural de um grupo específico e favorece a ideia de preservação.
} 
dão apenas entre pessoas e grupos, mas elas perpassam e envolvem os bens materiais. Assim, se por um lado, a preservação de objetos em museus ou a preservação de sítios e lugares cumprem uma importância social, cultural e política na sociedade ocidental, na medida em que essa materialidade é determinante para o reconhecimento de identidades individuais, sociais, culturais e históricas em âmbito regional, nacional ou global, por outro, a preservação desses patrimônios culturais, ao contrário do que o discurso oficial prega, é importante não para a preservação do passado, mas sobretudo para o presente, pois ele ocupa lugar central nos processos de socialização e conflitos sociais (FERREIRA, 2008:86).

Deste modo, o aspecto político desse processo é intensificado quando o discurso do gerenciamento patrimonial fornece estrutura e coerência às políticas e legislações do Estado. Nos gabinetes da administração estatal, esse fenômeno adquire roupagem autoritária, particularmente, quando tal política obscurece desigualdades e divisões sociais. A estrutura política deixa de ser democrática quando as instituições responsáveis pelo gerenciamento técnico do patrimônio cultural tendem a formular políticas públicas no intuito de capturar toda a sociedade dentro de um único entendimento de patrimônio, deixando de considerar a diferença e a dissonância (SMITH \& WALTERTON, 2011:30).

Segundo Smith (2008:66) esse processo formaliza a atuação profissional do arqueólogo estatal em duas funções: 'legislador' e/ou 'intérprete'. O 'legislador' atua como autoridade técnica através do poder institucional. Ele faz afirmações autoritárias que respaldadas pela autoridade do Estado, podem arbitrar sobre as regras processuais que assegurem a consecução da verdade. Já o 'intérprete' objetiva facilitar a comunicação entre os diferentes grupos da ordem social, no intuito de incluir suas exigências e contextos culturais entre as variáveis que estabelecem as políticas patrimoniais. Nesse sentido, o intérprete apresenta uma prática intelectual orientada pelos pressupostos teóricos da pós-modernidade. De qualquer forma, não é fácil para o intérprete escapar da postura autoritária do legislador e, às vezes, pode mesmo contribuir para afirmá-la, pois na medida em que reconhece as subjetividades dos grupos sociais, torna-se mais fácil manipulá-los.

O ponto é que a institucionalização do conhecimento arqueológico pelas agências estatais faz com que qualquer debate em torno do uso do patrimônio cultural seja intensamente político. $\mathrm{O}$ resultado de tal debate acarreta reais consequências a todas as partes envolvidas. 


\subsection{O patrimônio quilombola no contexto brasileiro.}

O atual contexto brasileiro apresenta um panorama sociopolítico peculiar relacionado às políticas públicas de patrimônio cultural. A Constituição em vigor desde 1988 foi elaborada como produto de uma demorada luta pela redemocratização do país. Seu texto expressa os anseios de reforma social, disposto a atender simultaneamente as conflituosas reivindicações de diferentes grupos sociais. Em pleno contexto pósmoderno de valorização da diversidade cultural, o Estado brasileiro abandona o discurso que tenta unificar o país sob a égide de uma única cultura e abraça o pluralismo cultural (PENIN, 2010).

De fato, pelo inciso 1 do artigo 215 da Constituinte, é imposto ao Estado o dever de proteger "as manifestações das culturas populares dos grupos participantes do processo civilizatório nacional", entre estes destaca-se os "afro-brasileiros". O caráter multicultural da nação prescreve ao aparato estatal, entre outras preocupações, a preservação do modo de vida das comunidades remanescentes de quilombo, uma vez que estas integram a cultura afro-brasileira.

A preocupação constitucional com o tema também é retomada no artigo 216 da mesma carta Magna:

"Art. 216. Constituem patrimônio cultural brasileiro os bens de natureza material e imaterial, tomados individualmente ou em conjunto, portadores de referência à identidade, à ação, à memória dos diferentes grupos formadores da sociedade brasileira, nos quais se incluem:

I - as formas de expressão;

II - os modos de criar, fazer e viver;

(...)

$V$ - os conjuntos urbanos e sítios de valor histórico, paisagístico, artístico, arqueológico, paleontológico, ecológico e científico.

$\S 1 .^{\circ}$ O poder público, com a colaboração da comunidade, promoverá e protegerá o patrimônio cultural brasileiro, por meio de inventários, 
registros, vigilância, tombamento e desapropriação, e de outras formas de acautelamento e preservação.

(...)

$\S 5 .^{\circ}$ Ficam tombados todos os documentos e os sítios detentores de reminiscências históricas dos antigos quilombos.",

Mais uma vez o artigo deixa clara a opção constitucional pelo pluralismo cultural no território nacional, quando destaca os "diferentes grupos formadores da sociedade brasileira". Ao mesmo tempo replica a ampla definição de Patrimônio Cultural da Convenção da Unesco de 1970, ao destacar como "Patrimônio Cultural brasileiro bens de natureza material e imaterial”, a exemplo: "I - as formas de expressão"; e "II - os modos de criar, fazer e viver". Outro fato de destaque e avanço no artigo da Constituição é juntar em um único item artefatos criados pela mão humana (“conjuntos urbanos e sítios de valor histórico, artístico e arqueológico"), com elementos naturais ("conjuntos paleontológico e ecológico”), além de destacar o “conjunto paisagístico" como um dos bens patrimoniais da nação passíveis de proteção.

Com esse espírito, a Constituição de 1988 lançou mão de um amplo reconhecimento de direito dos grupos historicamente excluídos, até então alijados das condições necessárias para uma existência digna. Da mesma forma, lançou a base Constitucional para outras formas de instrumentalizar a preservação patrimonial, de natureza totalmente diferente do artifício de tombamento, que serviu durante muito tempo (e ainda é utilizado em muitos casos), como única ferramenta do Instituto do Patrimônio Histórico e Artístico Nacional (IPHAN) e dos órgãos estaduais e municipais que cuidam do patrimônio cultural (PENIN, 2010:23).

Já o parágrafo $5^{\circ}$ - cuja significância do presente trabalho se faz relevante declara que "ficam tombados todos os documentos e os sítios detentores de reminiscências históricas dos antigos quilombos". Nesse parágrafo, dois pontos devem ser considerados tendo em vista que em um texto normativo oriundo de uma discussão marcadamente democrática, pautada por concessões, acordos e exigências de todos os tipos, os termos não primam por definições sistemáticas.

O primeiro ponto de destaque refere-se aos termos utilizados: o adjetivo “tombados" aparece relacionado ao substantivo "os sítios", em clara alusão aos sítios arqueológicos de cunho históricos com vestígios de assentamento quilombola. Nestes 
termos, o parágrafo não considera a definição de quilombo enquanto comunidade viva, mas estabelece o tombamento desses sítios arqueológicos referentes a construção de sua própria identidade de grupo, segundo antigos critérios de proteção. Como consequência, parte do território dessas comunidades onde venha a existir esses sítios arqueológicos, sofrem as restrições legais do instrumento usado para o tombamento (o Decreto Lei 25/37), devendo obedecer a restrições que em muitos casos divergem ou, simplesmente, são ignorados aos critérios de reconhecimento e uso patrimonial da própria comunidade $^{34}$.

O segundo ponto a ser destacado remete ao que Ulpiano Bezerra de Meneses (2007:48) denominou de cultural turn (virada cultural). Segundo ele, o termo cunhado por especialistas remete a tendência cada vez mais acentuada nas ciências sociais de concentrar na esfera da cultura fenômenos que deveriam manter seu contorno próprio, por exemplo, de natureza econômica ou social. Essa ocorrência não está restrita a esfera da política de Estado, mas de um modo de ver generalizado na sociedade, inclusive sendo apropriado e manipulado nas políticas das grandes corporações, nas indústrias culturais e publicitárias e nos meios de comunicação de massa.

Nesse sentido, muitos movimentos reivindicatórios dos direitos das classes excluídas (mais especificamente a exclusão social e econômica), também se apropriam dessa tendência, transferindo o foco das reivindicações para o reconhecimento étnico e os respectivos direitos de alteridade concedidos aos cidadãos de uma sociedade democrática e pluricultural.

Portanto, há uma diferença básica nos direitos reivindicados, assim como na forma como esses devem ser conduzidos. Para isso, se faz necessário toda uma série de novas frentes oriundas da política do patrimônio cultural. $\mathrm{O}$ artigo 68 do Ato das Disposições Constitucionais Transitórias (ADCT) pode ser visto como uma dessas frentes necessárias para conduzir o avanço na proteção dos direitos territoriais das comunidades quilombolas. Assim, o artigo consagra que:

\footnotetext{
${ }^{34}$ Até o momento, o único tombamento nos termos do parágrafo $5^{\circ}$ do artigo 216 da Constituição, feito após a promulgação da mesma, foi o quilombo do Ambrósio, em Ibiá, Minas Gerais. Este foi inscrito nos livros do tombo usando os mesmos antigos critérios de avaliação e proteção de valor histórico e arqueológico, configurando-se um caso excepcional entre os "sítios detentores de reminiscências históricas dos antigos quilombos" do país.
} 
"Aos remanescentes das comunidades dos quilombos que estejam ocupando suas terras é reconhecida a propriedade definitiva, devendo o Estado emitir-lhes os títulos respectivos."

Os termos utilizados no texto jurídico abre espaço para muitas discussões sobre as formas de interpretações. Como já discutimos, um dos pontos mais criticados é o uso do termo "remanescente das comunidades quilombolas", que configura uma comunidade esfarrapada, congelada no tempo, presa no passado, sem a devida autonomia de uma identidade construída no presente, com referências históricas em um passado de luta e transformação da situação dos afrodescendentes no Brasil. Outro ponto questionado refere-se aos que "estejam ocupando suas terras", o que sugere a plena legitimidade dominial em favor das comunidades, sendo-lhes garantidas posse e propriedade. Ou seja, no que tange ao reconhecimento da propriedade das terras, há uma clara proposta de inclusão social, procurando dar a posse de terras ao maior número possível de grupos afro-descendentes vivendo em comunidades quilombolas. Resgatando, assim, a dívida com essa significativa porção social que foi explorada e excluída durante séculos.

Entretanto, apesar do artigo 68 do ADCT garantir o direito das comunidades quilombolas à propriedade das terras de seus territórios, este não contem todos os elementos necessários para a caracterização desse processo, fazendo carência de um decreto que regulamente os critérios para sua efetivação. Com esse intuito foi redigido mais de um decreto ao longo de dez anos, um revogando o outro, sendo que o decreto sobre o assunto em voga atualmente data de 2003, sancionado pelo Presidente Luiz Inácio Lula da Silva, sob $n^{\circ} 4.887$, no qual regulamenta:

\begin{abstract}
Art. $\mathbf{1}^{\boldsymbol{0}}$ Os procedimentos administrativos para a identificação, o reconhecimento, a delimitação, a demarcação e a titulação da propriedade definitiva das terras ocupadas por remanescentes das comunidades dos quilombos, de que trata o art. 68 do Ato das Disposições Constitucionais Transitórias.
\end{abstract}

Segundo o deputado federal Luiz Alberto, o presente decreto foi editado após um longo e amplo processo de discussão que envolveu 13 ministérios, a Advocacia- 
Geral da União e o movimento quilombola. Seu principal objetivo é estabelecer os procedimentos e os processos a serem seguidos para efetivar a regulamentação fundiária das áreas de quilombos. Nesse sentido, ele atende ao conteúdo das normas internacionais de direitos humanos relativas ao direito à moradia, das quais o Brasil é signatário.

O novo decreto devolveu ao Ministério do Desenvolvimento Agrário e ao Incra a competência para identificar, reconhecer, delimitar, demarcar e titular essas terras, antes sob responsabilidade da Fundação Cultural Palmares. Para esse fim, o decreto permanece com a exigência da elaboração do Relatório Técnico de Identificação para fins de caracterização espacial do território a ser titulado. Esse relatório deve ser elaborado conforme os critérios estipulados no decreto, a destacar:

“Art. $2^{\mathbf{0}}$ Consideram-se remanescentes das comunidades dos quilombos, para os fins deste Decreto, os grupos étnico-raciais, segundo critérios de auto-atribuição, com trajetória histórica própria, dotados de relações territoriais específicas, com presunção de ancestralidade negra relacionada com a resistência à opressão histórica sofrida”.

(...)

$\S 3^{\circ}$ "Para a medição e demarcação das terras, serão levados em consideração critérios de territorialidade indicados pelos remanescentes das comunidades dos quilombos, sendo facultado à comunidade interessada apresentar as peças técnicas para a instrução procedimental”.

Interessante perceber como o decreto, mesmo não atualizando 0 termo "remanescentes das comunidades dos quilombos", considera a auto-atribuição como instrumento para o reconhecimento da identidade de grupo. Com resalvas sobre a “ancestralidade negra relacionada com a resistência à opressão histórica sofrida”, o artigo destaca o status quo pelo qual os membros dessas comunidades compartilham sua trajetória histórica. $\mathrm{Na}$ mesma tendência, funde identidade e território ao submeter o termo territorialidade segundo critérios indicados pela própria comunidade, podendo ser feito uso, inclusive, de "peças técnicas" que representem essa ancestralidade negra e a resistência à opressão em sua territorialidade.

Deste modo, o decreto abre caminho para os membros das comunidades quilombolas se apropriarem do discurso patrimonial como instrumento de reivindicação 
das terras. Assim, os sítios arqueológicos historicamente reconhecidos pelos quilombolas, as festas, as manifestações culturais e artísticas, os conhecimentos e manejo sobre os elementos da terra passam a ter uma nova significância na trajetória dessas comunidades, além das relações internas (entre seus membros) e externas (com as comunidades mais próximas), já estabelecidas.

Além disso, o patrimônio não se restringe apenas aos elementos reconhecidos na paisagem cultural do território. O próprio território é considerado um patrimônio cultural, à medida que é formado por um conjunto de paisagens culturais indicadas pela comunidade segundo seus próprios critérios de territorialidade.

Entretanto, é importante frisar que a autodenominação é direito de escolha de todos enquanto cidadãos. Apesar disso, o direito não é auto-sustentável, ele depende das implicações na relação com o outro. Ou seja, o ato de se autodenominar depende do auto-reconhecimento e do reconhecimento dos outros no complexo jogo das relações sociais, onde os artefatos, monumentos e lugares são acionados.

Ainda sobre o decreto, compete ao Ministério da Cultura, representado pelo IPHAN e Fundação Cultural Palmares, entre outras coisas, avaliar e produzir parecer sobre o Relatório Técnico, caso seja necessário. O decreto ainda cuidou de atualizar o parágrafo $5^{\circ}$ do artigo 216 da Constituinte, ao prever no artigo 18 que:

\begin{abstract}
Art. 18 Os documentos e os sitios detentores de reminiscências históricas dos antigos quilombos, encontrados por ocasião do procedimento de identificação, devem ser comunicados ao IPHAN.

Parágrafo único. A Fundação Cultural Palmares deverá instruir o processo para fins de registro ou tombamento e zelar pelo acautelamento e preservação do patrimônio cultural brasileiro.
\end{abstract}

Assim, o decreto procurou delimitar as esferas onde cada fenômeno deve ser tratado dentro de suas naturezas específicas. Apesar disso, não impede a tendência política das esferas se sobreporem em uma virada cultural. Ao contrário, valoriza o patrimônio cultural quilombola para além das relações internas e externas, antes estabelecidas localmente pelas comunidades. Na mesma proporção que existe essa projeção cultural, surgem os entraves nos processos de titulação desses territórios na forma de conflito intrínseco ao patrimônio cultural. 
Em um Estado pluricultural, o território quilombola é considerado, enquanto materialização da territorialidade desses povos, patrimônio nacional protegido pelo Estado. Ocorre que esse mesmo Estado também protege outros direitos e interesses, como, por exemplo, o direito a propriedade e o interesse do desenvolvimento econômico. Nesse momento estabelece o conflito entre dois interesses legítimos e constitucionalmente protegidos - o desenvolvimento cultural e econômico (PENIN, 2010:26).

No contexto contemporâneo que reconhece na biodiversidade o valor universal para a vida, são vistas como corretas as políticas patrimoniais de promoção do reconhecimento da diversidade cultural. Reconhecer, no entanto, não implica conhecer, apenas aceitar a diferença, mesmo que isso implique em uma contradição de interesses. Ao se tornar obrigação, a aceitação se resume em tolerância. Assim, a política patrimonial de valorizar o multiculturalismo apresenta-se como uma forma tolerante de organização social, mas não uma forma militante de conhecer ou de facilitar pontes interculturais que permitam aos diferentes coletivos conversarem, se conhecerem e criarem projetos com direitos respeitados.

\subsection{0 conflito intrínseco ao patrimônio cultural.}

Normalmente, apelamos para uma série de emoções profundas e permanentes afinidades que surgem de nossas associações com os sítios e objetos culturais. A ideia de patrimônio remete a termos confortáveis, definidos por lugares, histórias e valores compartilhados. O patrimônio é ingrediente fundamental da integração social à medida que fornece uma identidade e memória coletiva, garantindo a produção e reprodução da vida biológica, psíquica e social dos indivíduos.

Entretanto, para Ferreira (2008:82) a Arqueologia e o patrimônio cultural, no tocante à definição de identidades culturais, não apresenta um estado quieto e harmônico, mas um estado de ebulição. Como uma viagem que ocorre em mar agitado. Primeiro por que a prática arqueológica ainda traz as marcas e sinais do colonialismo e nacionalismo, resquício das relações históricas que a disciplina manteve em sua formação. Segundo, por conta da ambivalência das políticas de representação do patrimônio cultural. 
As dificuldades e conflitos surgem na medida em que a particular qualidade emocional do patrimônio, estendida a outras particularidades, não é reconhecida e compreendida da mesma forma. O elemento tido como patrimonial, sendo essencialmente compartilhado, recai sobre o fato de representar, em seu caráter mutável e polissêmico, valores e significados diferentes para diferentes coletivos sociais.

Por essa razão os profissionais do patrimônio (entre os quais se encontram os arqueólogos) são requisitados para atuarem como gestores do patrimônio cultural. Smith e Waterton (2011:49) argumentam que a qualidade emocional do patrimônio, assumida tacitamente como algo positivo e confortável por definir "quem nós somos" é uma retórica construída pelas agências responsáveis pelo gerenciamento do patrimônio.

Deste modo, o sentimento de inclusão que o patrimônio possa representar inevitavelmente, recai sobre ações excludentes que não comportam o caráter mutável e dinâmico da memória. A tensão entre selecionar e preservar o "melhor" (em um nível nacional ou mesmo global) de um lado, e prestar atenção no quanto a estrutura é importante para a localidade (independente do valor que pode ser atribuído para a nação ou pelos especialistas no assunto) de outro lado, é a principal questão de discussão dos recentes e contínuos métodos desenvolvidos.

Frequentemente os interesses das localidades são colocados em segundo plano frente aos interesses econômicos nacionais e internacionais. As comunidades quilombolas, indígenas, caiçaras, rurais e ribeirinhas estão sempre subjulgadas as necessidades econômicas impulsionadas pelo espaço urbano. Esse fato é comprovado quando comparamos as restrições de caráter cultural e ambiental que sofrem as comunidades locais - obrigadas a respeitar as leis protecionistas impostas sobre os patrimônios cultural e ambiental presentes em seus territórios - enquanto que aos empreendimentos considerados de grande envergadura ao desenvolvimento econômico nacional é permitido o resgate desses patrimônios, mediante o Estudo de Impacto Ambiental (EIA) cujo relatório prevê ações mitigatórias.

Para Anne Pyburn (2007) a ideia de significância que a Unesco utiliza para definir um sítio arqueológico ou elemento cultural como Patrimônio Mundial é desmentida pelo modo como ele é definido. Segundo a autora, os critérios de seleção dos sítios e manifestações culturais que compõe a lista foram elaborados por uma relação de árbitros de elite, segundo um conjunto de valores históricos constituídos na Europa e nos Estados Unidos. 
A natureza universal para a denominação de patrimônio baseia-se na suposição de que diz respeito ao "passado humano". Acreditar que exista um "passado humano" universalmente aceito é, certamente, priorizar uma visão de mundo em detrimento das outras. Como flexibilidade é claramente uma condição essencial para decisões dessa natureza, não é possível sustentar, como faz a Unesco, que seus critérios sejam completamente objetivos e universais.

Verificamos aqui uma hierarquia de valores formada em associação a definição de patrimônio. A ideologia que faz com que exista a lista do patrimônio da humanidade valorizado em primeira instância, influenciando a política externa mundial, o patrimônio nacional construindo identidades nacionais e, ainda, considerado de menor importância, o patrimônio comunitário relacionado à memória, operando no âmbito da comunidade local. Essa hierarquia patrimonial denota a existência de diferentes instâncias de poder entre as agências culturais que lidam com a política patrimonial nos níveis de influência política mundial, nacional, estadual, municipal e local/comunitário.

A hierarquia patrimonial não é constituída apenas pelas agências responsáveis pelo patrimônio, mas é reforçado por uma política de Estado maior, determinando quem pode fazer parte de uma "comunidade" ou não, segundo a lógica de mercado industrial. A resposta emocional da comunidade frequentemente se traduz em frustração, tendo seu patrimônio como intensamente emocional e pessoal e vendo essas emoções sendo desrespeitadas e mal interpretadas. A frustração ocorre da mesma forma quando os elementos emocionais do patrimônio - como os lugares, construções, materiais ou territórios - tornam-se o tema da gestão e, com isso, ocorrem intervenções por profissionais e agências patrimoniais (SMITH \& WATERTON, 2011:52).

Recentemente, ocorreu fato interessante por conta da construção de uma estrada de ferro no nordeste brasileiro, a Transnordestina. Durante o levantamento dos patrimônios culturais ao longo do percurso do empreendimento, para compor o Estudo de Impacto Ambiental, foi mapeada a comunidade quilombola do Carvalho, localizada na zona rural de Custódia, no sertão de Pernambuco. O projeto inicial previa que o percurso da estrada de ferro atravessaria parte do território quilombola, inclusive prevendo a destruição de algumas edificações. Entre essas edificações foi listada, pela equipe de arqueólogos, uma capela antiga que na ocasião da primeira etapa de campo estava em desuso, mas onde antigamente eram enterrados os moradores do quilombo. Conforme os trabalhos foram sendo desenvolvidos, os quilombolas tomaram conhecimento do projeto da Transnordestina e dos prejuízos que poderiam lhes 
ocasionar, inclusive com a demolição da capela que, segundo eles, possui mais de três séculos $^{35}$. Frente às ameaças e frustrações pela falta de reconhecimento e respeito ao seu patrimônio histórico-cultural e com o resultado das escavações arqueológicas e a identificação dos remanescentes esqueléticos terem confirmado as narrativas históricas dos mais velhos, a comunidade acionou o Ministério Público Federal em prol da preservação da capela. A retomada da comunidade quilombola frente a seu patrimônio edificado fez com que as obras da ferrovia no local fossem suspensas e a recomendação do Ministério Público é que o projeto altere o trajeto original (HATTORI, 2011, comunicação pessoal).

Deste modo vemos que os membros das comunidades não vivem essa frustração de forma passiva e rendida. Pelas ações diretas sobre os elementos de seus patrimônios, as comunidades exercem seu poder de influência no gerenciamento que existe sobre eles, tendo em vista as leis de um país que se diz pluricultural. Como estratégia de burlar a hierarquia e o gerenciamento institucional do patrimônio, as comunidades atribuem significados maiores ou menores aos elementos patrimoniais, criando e recriando suas tradições em constante diálogo com os profissionais e políticas das agências patrimoniais, incluindo os próprios arqueólogos.

Os Mandira são exemplo de negociação e parceria com as agências oficiais. Aparentemente estabelecem uma relação harmoniosa com os agentes externos, apesar das dissonâncias nos discursos estarem sempre presentes. Essas tensões existem não apenas pelas diferentes agendas e interesses, mas pela definição de patrimônio que cada grupo possui.

Assim, os Mandira sabem que a Casa-de-pedra foi construída para ser o engenho de beneficiar arroz, mas isso não impede que em suas narrativas a casa de pedra esteja associada aos escravos, que carregaram e encaixaram cada pedra exposta em suas paredes. Para os quilombolas a Casa-de-pedra é símbolo da história de resistência dos escravos, embora alguns especialistas do patrimônio definam o sítio como testemunha do período áureo da região, tempo em que os portos de Cananéia eram os que mais comercializavam arroz na colônia.

Eles também têm conhecimento de que sua concepção de patrimônio nunca será, nos termos das políticas públicas culturais, mais importante ou tão representativa quanto

\footnotetext{
${ }^{35}$ Informações coletadas no site da Globo nordeste, na reportagem publicada em 19 de agosto de 2010: http://pe360graus.globo.com/noticias/cidades/estradas/2010/08/19/NWS,519097,4,253,NOTICIAS, 766OBRA-TRANSNORDESTINA-ESBARRA-PROTESTO-QUILOMBOLAS.aspx.
} 
o patrimônio nacional. Talvez por isso façam questão de apresentar a Casa-de-pedra como local dos combates da revolução de 1932. Com isso, o sítio adquire status de patrimônio no sentido de que é parte da história a favor do Estado e, também, da história regional e local.

Da mesma forma, Seu Chico Mandira compreende que os sambaquis são estudados e interpretados pelos arqueólogos, especialistas nesse registro patrimonial, como vestígios dos "índios pré-históricos" que habitaram a região onde ele vive hoje com sua família. Mas sua experiência no local e os conhecimentos adquiridos com seus pais e avós deixam claro para ele que "os sambaquis surgiram depois do dilúvio que ocorreu na região, antes da chegada do primeiro Mandira”.

A ideia de patrimônio ser algo a ser ensinado reforça a suposição sobre o patrimônio como um instrumento legal e politicamente hierarquizado. Sob essa égide, os profissionais do patrimônio têm assumido a tarefa de educadores e são tidos como os porta-vozes do passado e dessas comunidades, pois o patrimônio arqueológico é retoricamente reconhecido por representar um passado comum à humanidade.

Entretanto, nosso objetivo não pode ser o de transmitir nossos valores sobre o patrimônio para os diferentes coletivos, pois patrimônio não é algo a ser aprendido. Ao contrário, é por essência polissêmico e mutável, significando muitas coisas para diferentes pessoas e comunidades segundo suas próprias experiências, crenças e relacionamentos historicamente estabelecidos. Devemos assim, permitir às pessoas opções de manter sua história, preservando a importância arqueológica nas leituras e estudos, a fim de satisfazer as particularidades dos diferentes grupos.

Nesse sentido, vemos o papel do arqueólogo na gestão do patrimônio cultural como um intérprete que, mesmo correndo o risco de recair nas ambivalências das políticas de representação desse patrimônio, objetiva reconhecer a influência que cada grupo social exerce sobre o patrimônio arqueológico de acordo com suas particularidades, facilitando assim a comunicação entre esses e as esferas do poder público. 


\subsection{Conclusão: Território Quilombola como Patrimônio.}

Sem desejar esgotar o debate, procuramos lançar argumentos em torno dos temas território, territorialidade e a relação destes com o patrimônio cultural e arqueológico nas comunidades quilombolas, a fim de aprofundar ainda mais as questões envolvidas na prática arqueológica nessas comunidades.

Importa destacar, ainda, que o arqueólogo deve estar atento ao fato de que na maioria das vezes, justamente por se tratar de uma comunidade quilombola, a qual exige o reconhecimento de sua alteridade em um Estado pluricultural, seus valores apresentam-se inteiramente distintos do entendimento dos cientistas e gestores públicos.

O objetivo dessa dissertação é demonstrar como a arqueologia em comunidade quilombola pode contemplar o caráter multi-interpretativo do seu patrimônio. Com base na proposta da multivocalidade, buscamos algumas abordagens de trabalho arqueológico que são alternativas ao modelo colonialista e nacionalista da prática arqueológica clássica ou tradicional. Diversificar as vozes interpretativas sobre o passado e os significados do registro arqueológico, investindo na incorporação de perspectivas culturais plurais, resulta em uma educação mútua entre arqueólogos e comunidade em torno do conceito de patrimônio.

Entre os Mandira verificamos que com o reconhecimento e identificação do patrimônio arqueológico o relacionamento com ele tende a se transformar. Tendo em vista o conjunto de interesses e saberes da comunidade, os princípios de preservação do patrimônio arqueológico são estabelecidos, tanto em termos da conservação ou utilização, como da transformação dos mesmos. O modo como os Mandira preservam o sítio arqueológico da Casa-de-pedra é um exemplo disso. Se antes a estrutura do sítio era para eles apenas uma fonte de matéria prima com fins diversos, hoje eles concebem o sítio como prova material de sua ancestralidade no local. O sítio é significativo para eles enquanto representação de sua história.

Assim, as narrativas sugerem a forma como os Mandira concebem os patrimônios arqueológicos de seu território, atribuindo um sentido segundo sua identidade e referencial históricos. É preciso entender a incorporação dos vestígios arqueológicos no território Mandira como um dos aspectos da construção e manutenção da sua identidade, na medida em que são elementos materiais que falam para eles e para nós (os outros) sobre a sua história de resistência, contribuindo para a manutenção de seu território e sua territorialidade enquanto objetivação da memória cultural. 
Para alem dos vestígios arqueológicos, o território Mandira é formado por lugares que são marcos referenciais investidos de significados. São lugares de significância histórica para a comunidade, como é o caso da região do Abacateiro ou a trilha do Porto-de-fora, ambos presentes nos relatos sobre a resistência à opressão sofrida por seus antepassados escravos. Todos esses lugares são reportados pelos Mandira por narrativas e nomenclaturas próprias, sendo incorporados (embodiment) por eles na sua vivência com esses lugares (WHITRIDGE, 2004). Trata-se de um conjunto de histórias que compõem uma rede articulada pela lógica de um modo particular de conhecimento e história quilombola, que legitima o reconhecimento e pertencimento deles ao seu território.

Com isso os Mandira negociam seus interesses em meio ao "mar agitado das políticas de representação do patrimônio cultural” (FERREIRA, 2008a:82). Eles reconhecem o caráter polissêmico do patrimônio e por este exigem o reconhecimento de sua alteridade. $\mathrm{Na}$ ambivalência das políticas culturais e pela "virada cultural" sobre as políticas sociais, os Mandira desejam ter sua territorialidade reconhecida e o direito ao seu maior patrimônio: o território.

Entretanto, como ressalta Amanda Barretta Almeida (2004:83) é importante salientar que atualmente o confronto dos quilombolas se dá através de manifestações públicas, de negociações e de trabalho de base e de ações judiciais (junto ao Ministério Público, por exemplo). Assim, o lugar de resistência não é produzido no processo da luta, o que acontece é o inverso: a luta é pela permanência, pelo direito ao uso e gerenciamento do território. O reconhecimento nessa luta não se manifesta pela cor da pele - como seria para o movimento negro. Nessa nova esfera de luta é o corpo do excluído, por vezes invisível, que se manifesta, o corpo que tem medo de perder seu lugar, seu território, que é, então, extensão de si mesmo. A reivindicação do título da terra é a garantia de domínio, de posse desse território que já é seu e da reprodução de seu saber ancestral. Ambos consistem no reconhecimento do Estado da sua própria existência, história e direitos sobre o território.

Apesar de não haver garantia de que as relações de força serão mais niveladas, a luta pelo reconhecimento de um ponto de vista nativo da História, é hoje uma das armas desta resistência secular. É neste sentido que vemos a prática arqueológica em território quilombola. Dentre as questões de interesse público, a Arqueologia pode promover o direito das populações de participar do manejo e do reconhecimento de suas representações sobre o patrimônio material de seu território (FUNARI, 2001; SÍLVA, 
2009). Essa abordagem do trabalho arqueológico se reveste de especial importância nos contextos pós-coloniais, junto aos grupos sociais que, no passado, foram sistematicamente ignorados ou excluídos, como foi o caso das comunidades quilombolas.

As parcerias firmadas entre a comunidade e os agentes do patrimônio, as universidades, as diferentes instâncias do poder público, são novas estratégias de resistência frente às ameaças de segregação e despejo de seu território, e refletem o desejo do grupo em participar como agente de seu destino, como cidadãos reconhecidos por sua alteridade.

Assim como a construção da identidade e alteridade é situacional e, portanto, em constante transformação, a territorialidade também é mutável sendo recriada todos os dias. É essa dinâmica que os Mandira querem ver reconhecida pelas diferentes instâncias sociais e políticas públicas.

Por fim, retomamos as palavras de Diegues \& Nogara (op. cit:141)

"Considerando a importância da simbiose homem-ciclos naturais existentes nas culturas tradicionais, a noção de Estação Ecológica que não leva em conta a história dos moradores é incompreensível e inaceitável. A disjunção forçada entre a natureza e a cultura tradicional, onde os moradores poderão sofrer restrições em suas atividades do fazer patrimonial, e também do saber, representa a imposição de um mito moderno: o da natureza intocada e intocável, próprio da sociedade urbana-industrial sobre os mitos e simbolismos das sociedades tradicionais".

Reconhecer a importância do saber tradicional enquanto técnica para conceituar o patrimônio é implicitamente reconhecer que as populações detentoras destes saberes são sujeitas de sua história e portadoras desse conhecimento ancestral. Portanto, devem ser consideradas como agentes protagonistas do conhecimento e, sobretudo, gestoras do patrimônio existente em seu território. Afinal, a manutenção desse patrimônio depende inexoravelmente da manutenção do território dessas populações. 


\section{FONTES PRIMÁRIAS.}

Arquivo Público do Estado de São Paulo:

- Maço de População de Cananéia;

- Registro de Terras da Província, distrito de Cananéia;

- Ofícios Diversos de Cananéia (Caixa 00862).

Ofício de registro de Imóveis, títulos e documentos, civil de pessoa jurídica e civil das pessoas naturais e de interdições e tutelas da sede. Comarca de Cananéia - Estado de São Paulo.

- Certidão do livro do Registro Facultativo de Terras. Número da ordem 3.

Registro de Imóveis. Comarca de Jacupiranga - Estado de São Paulo.

- Livro número 2. Matrícola 4.027. 


\section{BIBLIOGRAFIA:}

AB'SABER, Aziz N. Brasil: Paisagens de Exceção. O Litoral e o Pantanal Matogrossense: Patrimônios Básicos. Cotia, SP: Ateliê Editorial, 2006.

. "Potencialidades paisagísticas brasileiras". In.: Boletim Geomorfologia. IG/USP. São Paulo, pp 1-21:1977.

ADAMS, Cristina. Caiçaras na Mata Atlântica: pesquisa científica versus planejamento e gestão ambiental. São Paulo: Annablume: FAPESP, 2000.

AGOSTINI, Camila. "Entre senzalas e quilombos: "comunidades do mato" em Vassouras do Oitocentos". In: ZARANKIN, Andrés; SENATORE, Maria Ximena (orgs). Arqueologia da Sociedade Moderna na América do Sul: Cultura Material, Discursos e Práticas. Buenos Aires: Ediciones del Tridente, 2002: 19-30.

"Resistência Cultural e Reconstrução de Identidades: Um Olhar

Sobre a Cultura Material de Escravos do Século XIX". In. Revista de História Regional. Departamento de História - Universidade Estadual de Ponta Grossa - Vol. 3, $\mathrm{n}^{\mathrm{o}} 2$, pp. 113-137, Inverno, 1998.

ALLEN, Scott. "A 'Cultura Mosaic' at Palmares? Grappling with the Historical Archaeology of a Seventeenth-century Brazilian Quilombo" in: Cultura Material e Arqueologia Histórica. Funari, P. P. (org.), Unicamp (IFCH), Campinas, 1998.

ALMEIDA, Antônio P. de. Memória Histórica sobre Cananéia. Vol. I. Coleção da Revista de História. São Paulo - Brasil. 1963.

. "Memória Histórica de Cananéia (II)". In: Revista de História, São Paulo: FFLC/USP. vol. 22, Ano 46, p.191-237, 1961.

. "Memórias Memoráveis". In: Revista do Arquivo Municipal. São Paulo: out-dez, ano XV. Vol. CXX, pp. 2-28, 1948.

ALMEIDA, A. Wagner B. de. "Os quilombos e as novas etnias: é necessário que nos libertemos da definição arqueológica". In: LEITÃO, Sérgio (Org.). Direitos 
territoriais das comunidades negras rurais. Brasília: Documentos do ISA, n. 5, pp: 11$18,1998$.

ANSCHUETZ, Kurt; WILSHUSEN, Richard e SHEICK, Cherie. "An Archaeology of Landscape: Perspectives and Directions". In: Journal of Archaeological Research 9(2), 2001: 157-211.

ASHMORE, Wendy. "Biographies of Places at Quiriguá, Guatemala". In.: The Archaeology of Meaningful Places, edited by B. J. Bowser and M. N. Zedeño, pp. 1-14. University of Utah Press, Salt Lake City, 2009.

BARBOSA, Wilson do N. O Problema do Negro na História do Brasil. Salvador. Salão da Reitoria - Universidade Federal da Bahia, 1985.

BARRETTA ALMEIDA, Amanda. Entre o Ser e o Estar: Existir e Resistir. Identidade, Luta e Modernização em Comunidades de Quilombos - Vale do Ribeira-SP. Trabalho de Graduação Individual (TGI). Depto de Geografia - FFLCH/USP. Orientação Prof. Dr. Heinz Dieter Heidemann, 2004.

BARROS, Mirian \& COLAVITE, Ana P. “Geoprocessamento aplicado a estudos do caminho de Peabiru”. In.: Revista da ANPEGE, v. 5, p. 86 - 105, 2009.

BARTH, Fredrik. "Grupos étnicos e suas fronteiras: A organização social da diferença cultural”. In: POUTIGNAT, Philippe \& STREIFF-FEART, Jocelne. Teorias da etnicidade. São Paulo: UNESP, 1997.

BARTON, C. Michael; BERNABEU, Joan; AURA, J. Emili; GARCIA, Oreto; SCHMICH, Steven; MOLINA, Llui. "Long term socioecology and contingent landscape". In: Jornal of archaeological method and theory. 11 (3), 2004: 253-296.

BASTOS, Rossano L. Uma Arqueologia dos Desaparecidos: Identidades vulneráveis e memórias partidas. Instituto do Patrimônio Histórico e Artístico Nacional. Superintendência Regional do IPHAN. São Paulo-SP, 2010.

BAVA DE CAMARGO, Paulo F. Arqueologia de uma cidade portuária: Cananéia século XIX-XX. Tese. São Paulo: MAE/USP, 2009. 
BINFORD, Lewis. "The archaeology of the place". In:Working at archaeology. New York: Academic Press, 1983.

. "Bihavorial archaeology and the Pompeii premise". In: Journal of atchaeological resources. 37, 1981:195-208. . "Achaeology as anthropology". In: American antiquity, 28 (2): 217$25,1962$.

BINFORD, L. R. \& BINFORD, S. R. New perspectives in archaeology. Chicago: Adline, 1968.

BLANTON, Richard. Monte Alban: Settlement Patterns at the Ancient Zapotec Capital. Academic Press, New York. 1978.

BONETTI, Charles. Análise do Padrão de Assentamento dos Grupos ColetoresPescadores do baixo Vale do Ribeira de Iguape: Levantamento dos Sítios Arqueológicos. Dissertação - FFLCH/USP, 1997.

BROWN, Linda A. Dangerous place and wild spaces: creating meaning with materials and places at contemporary Maya shrines on El Duende Mountain. In: Journal of Archaeological Method and Theory, 11 (1), 2004:31-58.

BURKE, Heather \& SMITH, Claire. "Vestiges of Colonialism: Manifestations of the Culture/Nature Divide in Australian Heritage Management". In.: MESSENGER, Phyllis M. \& SMITH, George S. (eds.). Cultural Heritage Manegement. A global perspective. University Press of Florida, Gainesville/ Tallahassee/Tampa/Boca Raton, 2010.

CALIPPO, Flávio. R. Sociedades Sambaquieiras, Comunidades Marítimas. Tese (doutorado). São Paulo: MAE/USP, 2010.

. Os Sambaquis da Ilha do Cardoso, Cananéia, SP: Um Estudo de Caso em Arqueologia Subaquática. Dissertação (mestrado) - FFLCH/USP, 2002.

CALIXTO, Benedito. Vila de Itanhaém. Segundo povoado fundado por Martin Afonso de Souza em 1532. Santos: Diário de Santos, 1895. 
povoação de Piratininga". In: Revista do Instituto de História e Geografia de São Paulo. São Paulo. V.13, pp.255-263: 1908.

CAPRA, Fritjof. A Teia da Vida. Uma nova compreensão cientifica dos sistemas vivos. Cultrix \& Amana-key: São Paulo, 1996.

CARLE, Cláudio. B. A organização dos assentamentos de ocupação tradicional de africanos e descendentes no Rio Grande do Sul, nos séculos XVIII e XIX. Tese. POA, PUC-RS, 2005.

CARNEIRO, Edison. Antropologia do negro brasileiro. RJ: Agir, 2005. . O quilombo dos Palmares. São Paulo: Companhia Editora Nacional, 1988.

. Capoeira. RJ: Campanha de Defesa do Folclore Brasileiro, 1975.

CARNEIRO DA CUNHA, Manuela. Antropologia do Brasil: mito, história e etnicidade. São Paulo, SP: Editora Brasiliense, 1986.

CARRIL, Lourdes de F. B. Terra de Negros no Vale do Ribeira: territorialidade e resistência. Dissertação (Mestrado) - Depto de História - FFLCH/USP, 1995.

CARROLL, Alex. K.; ZEDEÑO, Maria N.; STOFFLE, Richard. W. "Land of the ghost dance: a cartography of numic ritual". In: Journal of Archaeological Method and Theory, 11 (2), 2004:127-156.

CARVALHO, Aline Vieira de. Palmares como espaço de sonhos: análise dos discursos arqueológicos sobre a Serra da Barriga. Dissertação (mestrado). Depto. de História Instituto de Filosofia e Ciências Humanas da UNICAMP, 2005.

CARVALHO, Ídolo de. "Cananéia, o primeiro povoado do Brasil. A Saga do Bacharel. A verdadeira história.”, SP: Ed. do Autor, 2010.

CASCUDO, L. da Câmara. "Made in África”, SP: Global, 2001.

CHALHOUB, Sidney. Visões da Liberdade. Uma História das Últimas Décadas da Escravidão na Corte. São Paulo: Companhia das Letras, 1990. 
CHANG, K. C. The Archaeology of the Ancient China. Yale University Press, New Haven, 1963.

CHIQUINHO, Cleber R. (org). Saberes Caiçaras. A cultura caiçara na história de Cananéia. São Paulo: Páginas \& Letras, 2007.

CLARKE, David. "Archaeology: the loss of innocence". In.: Antiquity Journal, vol. 47 no. 185 , pp. 6-18:1973.

DAVID, Nicholas \& KRAMER, Carol. Etnoarchaeology in Action. Cambridge: Cambridge University Press, 2001.

DEMARTINI, Cristina. M. C. Caracterização Cultural e Gerenciamento do Patrimônio Arqueológico do Parque Estadual da Ilha do Cardoso. Tese - FFLCH/USP, 2003.

DIEGUES, Antônio C. O Mito Moderno da Natureza Intocada. 3 ed., São Paulo: Hucitec, NUPAUB/USP, 2008.

(org.). Enciclopédia Caiçara, vol.5 - Festas, lendas e mitos caiçaras. São Paulo: Nupaub/CEC/USP, Hucitec, 2006.

(org.). Enciclopédia Caiçara, vol.4 - História e memória caiçara. São Paulo: Nupaub/CEC/USP, Hucitec, 2005.

(org.). Enciclopédia Caiçara, vol.3 - O olhar estrangeiro. São Paulo: Nupaub/CEC/USP, Hucitec, 2005.

(org.). Enciclopédia Caiçara, vol.2 - Falares caiçaras. São Paulo: Nupaub/CEC/USP, Hucitec, 2004.

(org.). Enciclopédia Caiçara, vol.1 - O olhar do pesquisador. São Paulo: Nupaub/CEC/USP, Hucitec, 2004.

. Ilhas e Mares -simbolismo e imaginário. São Paulo: Hucitec, NUPAUB/USP, 1998.

- Pesca e marginalização no litoral paulista (dissertação de mestrado). NUPAUB/CEMAR. Universidade de São Paulo. USP. São Paulo, SP. 1973. 
DIEGUES, Antônio C. \& NOGARA, Paulo J. N. O Nosso Lugar Virou Parque: Estudo socioambiental do Saco do Mamanguá- Parati- Rio de Janeiro. 3 ed., São Paulo: Hucitec, NUPAUB/USP, 2005.

DUARTE, Paulo. O Sambaqui Visto Através de Alguns Sambaquis. In: Pré-História Brasileira. IPH-USP, 1968.

DURAN, Leandro D. Arqueologia Marítima de um Bom Abrigo. (tese de doutorado). MAE-USP. São Paulo, 2008.

FAIRBANKS, Charles. H. "The Plantation Archaeology of Southeastern Coast". In: Historical Archaeology, (18): 1, 1-14, 1984.

FAIRCLOUGH, Graham. "New Heritage, an Introductory Essay - People, Landscape and Change". In.: FAIRCLOUGH, Graham; HARRISON, Rodney; JAMESON Jr., John; SCHOFIELD, John. (eds.). The Heritage Reader. Routledge, Taylor\& Francis Group, London \& New York, pp. 297-303:2008.

. "The Long Chain'. Archaeology, historical landscape characterization and time depth in the landscape". In.: FAIRCLOUGH, Graham; HARRISON, Rodney; JAMESON Jr., John; SCHOFIELD, John. (eds.). The Heritage Reader. Routledge, Taylor\& Francis Group, London \& New York, pp. 408-421:2008.

FERREIRA, Lúcio M. "Arqueologia da Escravidão e Arqueologia Pública: Algumas interfaces". In: Vestígios. Revista Latino Americana de Arqueologia. Laboratório de Arqueologia- UFMG. Vol. 5 no. 1, pp. 7-23, 2011.

\section{"Patrimônio, Pós-Colonialismo e Repatriação}

Arqueológica". In: Ponta de Lança: História, Memória e Cultura, (1): 37-62: 2008a. . "Sob Fogo Cruzado: Arqueologia Comunitária e Patrimônio Cultural". In: Arqueologia Pública (UNICAMP), v. 03 pp. 81-92: 2008b.

FIABANI, Adelmir. Mato, palhoça e pilão: O quilombo, da escravidão às comunidades remanescentes [1532-2004]. São Paulo: Expressão Popular, 2005.

FIGUTI, Levy. (coord). Os sambaquis fluviais do vale do rio Ribeira de Iguape, SP. Simpósio, SP. São Paulo: Sociedade de Arqueologia Brasileira, 2003. 
"Homem pré-histórico. O molusco e o sambaqui: considerações sobre a subsistência dos povos sambaquieiros". In.: Revista do MAE, São Paulo: v. 3, pag. 67-80, 1993.

FRANCHI, Cleide. Arqueologia Histórica do baixo vale do Ribeira: inventário dos sitios entre Iguape e Cananéia. Dissertação, FFLCH/USP, 1999.

FREITAS, Décio. Palmares: A guerra dos escravos. Rio de Janeiro: Graal, 1978. . Escravos e Senhores-de-Escravos. Porto Alegre: Escola Superior de Teologia São Lourenço de Brindes, Caxias do Sul:Universidade de Caxias do Sul, 1977.

FUNARI, P. Paulo. O papel estratégico da Arqueologia na delimitação de terras indígenas e quilombolas. Paper apresentado no VII Encontro Nacional de Estudos Estratégicos, patrocinado pela Presidência da República, em Brasília, novembro/2007. E-Premissas, v.3, pp. 1-15, 2008

\section{"Teoria e métodos na Arqueologia contemporânea: o contexto da}

Arqueologia Histórica". In: Primeira versão. n. 120, IFCH/UNICAMP, pp. 13-20, Abril de 2003a.

. "Heterogeneidade e conflito na interpretação do quilombo dos

Palmares". In: Revista de História Regional. n. 6, v.1, pp. 11-18, verão 2001a.

“A Arqueologia Histórica em uma perspectiva mundial". In:

Revista de História Regional. n. 6, v.2, pp. 35-41, inverno 2001b.

- (org). Cultura Material e Arqueologia Histórica. Campinas, SP: UNICAMP/IFCH, 1998.

- Teoria Arqueológica na América do Sul. Campinas: Instituto de Filosofia e Ciências Humanas (Coleção "Primeira Versão" 76), 1998.

. "O estudo arqueológico de Palmares e a sociedade brasileira". In:

África: Revista de Estudos Africanos. USP, São Paulo, n. 20-21. pp. 93-103, 1997/1998.

"A 'República de Palmares' e a arqueologia da Serra da Barriga". In: Revista USP. São Paulo, no 28, pp. 6-13, dezembro/fevereiro 1995-1996a. 
"O estudo arqueológico do Quilombo de Palmares". In: História em Revista. Publicação do Núcleo de Documentação Histórica da UFPEL. Pelotas: Editora e Gráfica da UFPEL, pp. 201-208, 1996b.

\section{"O amadurecimento de uma arqueologia histórica mundial". In:}

Revista de História. Departamento de História da Universidade de São Paulo, n. 135, FFLCH-USP, pp.163-168, $2^{\circ}$ semestre de 1996c.

. A cultura material de Palmares: o estudo das relações sociais de um quilombo pela Arqueologia. Idéias, São Paulo: FDE, n. 27, pp. 37-42. 1996d.

FUNARI, P. Paulo; DOMINGUEZ, Lourdez; FERREIRA, L. Menezes. Patrimônio e cultura material. Campinas: Instituto de Filosofia e Ciências Humanas (IFCH), Universidade Estadua de Campinas (UNICAMP), 2006.

FUNARI, P. Paulo e CARVALHO, Aline V. "O patrimônio em uma perspective crítica: o caso do Quilombo dos Palmares". In: Diálogos, Maringa, PR, v.9, n.1, p. 33-48, 2005.

. Palmares ontem e hoje. Rio de Janeiro: Jorge

Zahar Ed., 2005.

FUNARI, P. Paulo; ORSER JR, Charles E. \& SCHIAVETTO, Solange N. O. (Orgs). Identidades, discurso e poder: Estudos da arqueologia contemporânea. São Paulo: Annablume; Fapesp, 2005.

FUNARI, P. Paulo \& FOGOLARI, E. Paulo. Estudos de Arqueologia Histórica. Erechim, 2005.

FUNARI, P. Paulo \& DOMINGUEZ, Lourdez. "Esclavitud y Arqueología de la resistencia en Cuba y Brasil". In: Revista do Museu de Arqueologia e Etnologia. São Paulo, n. 14, pp. 209-223, 2004.

FUNARI, P. Paulo \& ORSER JR, Charles E. “Arqueologia da resistência escrava". In: Cadernos do LEPAARQ - Textos de antropologia, arqueologia e patrimônio. v. I, $\mathrm{n}$. 2. Pelotas, RS: Editora da UFPEL. jul-dez., 2001. 
Estudos Ibero-Americanos. PUCRS. V. XVIII, n. 2, p. 53-69, dezembro, 1992.

GARCIA, Caio. D. R. Estudo Comparado das fontes de Alimentação de duas populações pré-históricas do litoral paulista. Tese (Doutorado) - Instituto de Biociências, USP, 1972.

GARCIA, Caio. D. R. \& UCHÔA, D.P. Piaçaguera: um sambaqui do litoral do Estado de São Paulo. Revista de Pré-História, 2:11-81, 1981.

GASPAR, Madu. Aspectos da organizção social de um grupo de pescadores, coletores e caçadores: região compreendida entre a Ilha Grande e o delta do Paraíba do Sul, Estado do Rio de Janeiro. Tese de Doutorado. São Paulo, USP, 1991.

GNECCO, Cristóbal. Texto apresentado no Seminário Internacional de Gestão do Patrimônio Arqueológico Pan-Amazônico, Manaus, nov/2007.

. Multivocalidad Histórica. Hacia uma cartografia postcolonial de la arqueologia. Universidad de los Andes: Departamento de Antropologia, Bogotá, 1999.

GOMES, Flávio dos S. “Quilombo do Rio de Janeiro no século XIX”. In: Reis, João José; Gomes, Flávio dos S. (Org.). Liberdade por um fio - História dos quilombos no Brasil. São Paulo. Companhia da Letras, 1996.

GONZALES-RUIBAL, Alfredo. G. La Experiencia Del Outro. Uma introducción a La etnoarqueología. Madrid: Editorial Akal Arqueologia, 2003.

. "De la Etnoarqueologia a la Arqueologia do

Presente". In: SALAZAR, DOMINGO, AZKÁRRAGA y BONET (coord). Mundos Tribales: Uma visión etnoarqueológica. Museu de Pré-história de Valencia, 2008.

GUIMARÃES, Carlos M. Remanescentes de quilombos, interdisciplinaridade e a SAB (Sociedade de Arqueologia Brasileira). In. Anais da reunião da Associação Brasileira de Antropologia XXI. Vitória, 1998.

. Diagnóstico histórico - social sobre a comunidade de Porto dos Corí - Município de Leme do Parado, MG. Belo Horizonte, 1997. 97 f. 
- Quilombo e Política (MG-séc.XVIII). In: Revista de História. São Paulo, FFLCH USP, n.132, $1^{\circ}$ semestre de 1995.

. O Quilombo do Ambrósio: lenda, documentos e arqueologia.

Estudos Ibero-Americanos. PUCRS, XVI (1, 2), pp. 161-174, jul-dez., 1990.

GUIMARÃES, Carlos M. \& LANNA, Ana L. D. Arqueologia de Quilombos em Minas Gerais. Pesquisas. n. 31, pp. 164-163, 1980.

GUIMARÃES. C. M. \& CARDOSO, J. S. “Arqueologia do quilombo: Arquitetura, Alimentação e Arte (Minas Gerais)". In: MOURA, Clovis (org). Os quilombos na dinâmica social do Brasil. Maceió: EDUFAL, 2001, pp. 35-58.

GUSMÃO, Nelsa M. M. A dimensão política da cultura negra no campo: uma luta, muitas lutas. (Doutorado) - Depto de Antropologia - FFLCH/USP, 1990.

. "Terra de Pretos, Terra de Mulheres - Terra, Mulher e

Raça num Bairro Rural Negro”. In: Fundação Cultural Palmares. p.147-208, 1996.

. "Terra de uso comum: oralidade e escrita em confronto".

In: Afro-Asia (UFBA), Salvador, v.16, n. Nov, 1995:116-132.

HATTORI, Márcia. "Entre a capela, a ferrovia e as comunidades: Arqueologia, conflitos e Educação no sertão pernambucano - uma proposta para o sítio Fazendinha". Projeto de mestrado em andamento pelo Programa de Pós-graduação em Arqueologia, MAE/USP, 2011.

HODDER, Ian. Archaeological theory today. Cambridge, UK; Malden, MA: Polity Press: Blackwell Publishers, 2003.

. Interpreting archaeology: finding meaning in the past. London; New York: Routledge, 1996.

. Theory and practice in archaeology. London; New York: Routledge, 1992. 
"Post- processual Archaeology". In: Ian Hodder \& Scott Hudson (Eds.) Reading the Past. Current Aproaches to Interpretation in archaeology. Cambridge, Cambridge University Press. 1992.

. Reading the past. Current approaches to interpretation in archaeology.

Cambridge/ Nova York:Cambridge University Press, 1986 . The present past. Nova York: Pica Press, 1982a.

- Symbolic and structural archaeology. Cambridge: Cambridge

University Press. 1982b.

INGOLD, Tim. "Landscape temporality". In: INGOLD, T. Perception of Enviroment. Cambridge, Polity Press, 2000.

JACKSON, Gary. \& SMITH, Clair. "Living and learning on Aboriginal lands: descolonizing archaeology". In: Indigenous archaeologies. London: Routledge, pp.328-351, 2007.

JONES, Siân. "Categorias históricas e a práxis da identidade: a interpretação da etnicidade na arqueologia histórica". In: FUNARI, P. Paulo A.; ORSER, Charles E. Jr. \& SCHIAVETTO, Solange N. de O. (Orgs). Identidades, discurso e poder: Estudos da arqueologia contemporânea. São Paulo: Annablume; Fapesp, 2005. pp. 27-43.

KENT, Susan. Method and theory for activity área research: na ethnoarchaeological approach. New York: Columbia University Press, 1987.

KRONER, Ricardo. “Contribuição para a etnologia Paulista". In: Revista do Instituto Histórico e Geográfico de São Paulo. SP, t.VII, 1902:471-479.

LA ROSA CORZO, G. “Os espaços da resistência escrava em Cuba”. In: FUNARI, Pedro Paulo A.; ORSER, Charles E. Jr. \& SCHIAVETTO, Solange Nunes de Oliveira (Orgs). Identidades, discurso e poder: Estudos da arqueologia contemporânea. São Paulo: Annablume; Fapesp, 2005. pp. 45-57.

LEE, L. "Consumerism, Social Relations, and Slavery at Late Antebellum Poplar Forest (1828-1862)". In: Annual Meeting of the Council for the Northeast Historical Archaeology in St. Mary's City, MD, 15 pp. 2008. 
LEONE, M. “A Historical Archaeology of Capitalism”. In: American Anthropologist, (97):2, 251-268, 1995.

LEVI-STRAUSS, Claude. "A Ciência do Concreto". In.: O Pensamento Selvagem. São Paulo, Editora Nacional, 1976.

LIMA, Mesquitela. O Dilúvio Africano. Luanda: Instituto de Investigação Científica de Angola, 1972.

LUCCOK, John. Notas sobre o Rio de Janeiro e partes meridionais do Brasil. São Paulo/ Belo Horizonte: Edusp/Itatiaia, 1975. Série Reconquista do Brasil, 21.

LUMBRERAS, Luiz. La arqueologia como ciencia social. Lima, Ed. Histar, 1974.

MACEDO, Roberto S. Etnopesquisa Crítica Etnopesquisa-Formação. Brasília: Liber livro editora, 2006.

MAACK, Reihnard. Sobre o Itinerário de Ulrich Schmidel Através do Sul do Brasil (1552 - 1553). Curitiba - PR, 1959.

MACEDO, Roberto S. Etnopesquisa crítica etnopesquisa formativa. Brasília: Liber livro editora Ltda, 2006.

MADRE DE DEUS, Frei. G. Memórias para a História da Capitania de São Vicente, hoje chamada de São Paulo. Livraria Martins Francisco Editórial S.A. São Paulo, 1953.

MAGDALENA, Bianca C. Reza a Lenda. A cultura rural caiçara de Cananéia vivenciada no bairro rural de Santa Maria. Londrina: Idealiza Gráfica e Editora, 2008.

MAGDALENA, Bianca C. \& NASCIMENTO, Juliano S. (Org.). Uso das plantas medicinais por comunidades tradicionais caiçaras de Cananéia. Londrina: Idealiza Gráfica e Editora, 2009.

MAGALHÃES, Nícia W. de. Descubra o Lagamar. São Paulo: Embratur, 1997.

MALHEIRO, A. M. Perdigão. Escravidão No Brasil: Ensaio Histórico-Juridico-Social. Rio de Janeiro: Typographia Nacional, 1866. 
MARQUES, M. E. Azevedo. Apontamentos históricos, geográficos, biográficos, estatísticos e noticiosos da província de São Paulo. Publicação por deliberação do Instituto Histórico e Geográfico Basileiro. São Paulo: Livraria Martins Editora, [1952].

MARTIN, L., SUGUIO, K. \& FLEXOR, J. M. "Informações adicionais fornecidas pelos sambaquis na reconstrução de paleolinhas de praia quaternária: exemplos da costa do Brasil”. In.: Revista de Pré-História, Instituto de Pré-História da Universidade de São Paulo, 6, 1986: 128-147.

MENESES, Ulpiano T. B. "Premissas para a formulação de políticas públicas em arqueologia". In: Patrimônio Arqueológico: o desafio da preservação. Revista do Patrimônio Histórico e Artístico Nacional. no. 33. pp. 37-57: 2007.

MERRIMAN, Nick. Public Archaeology. London: Routledge, New York, 2004.

MEIHY, José Carlos Sebe Bom. Manual de história oral. São Paulo: Edições Loyola, 2005.

MILlER, D.; ROWLAND, M. \& TILlEY, C. Domination and Resistence. Ed by H. F. Cleere, 1989.

MONTENEGRO, Antônio T. "História, metodologia, memória”. In.: Revista de História Oral, v. 13, n. 1, 2010: 7-12.

. "História e Memória. Combates pela História". In.:

História Oral (Rio de Janeiro), v. 10, p. 27-42, 2007.

MORSE, Richard M. Formação histórica de São Paulo. São Paulo, Difel, 1970.

MOURA, Clovis. História do negro no Brasil. São Paulo: Editora Ática, 1996.

. Quilombos. Da Resistência ao Escravismo. São Paulo: Editora Ática, 1993.

. Quilombos e a rebelião negra. São Paulo: Brasiliense, 1981.

MORAES, J. Luis. "Reflexões acerca da arqueologia preventiva". In: Patrimônio: atualizando o debate. Revista do IPHAN, 2006. 
MUNANGA, Kabengele. “Origem e Histórico do Quilombo na África". In: Revista USP. São Paulo, v.28, p. 56-64, 1995.

NEVES, W. \& OKUMURA, M. M. Afinidades biológicas de grupos pré-históricos do vale do rio Ribeira de Iguape (SP): uma análise preliminar. In.: Revista de Antropologia, SP, USP, v.48 nº. 2, 2005.

ORSER, Charles Jr. "O desafio da raça para a arqueologia histórica americana". In: FUNARI, Pedro Paulo A.; ORSER, Charles E. Jr. \& SCHIAVETTO, Solange Nunes de Oliveira (Orgs). Identidades, discurso e poder: Estudos da arqueologia contemporânea. São Paulo: Annablume; Fapesp, 2005. pp. 59-75.

. "The archaeology of the African diaspora". In: Annual Review of Anthropology, 1998 (27):63-82. . A Historical Archaeology of the Modern World. Plenum Press: New

York, 1996. - Introdução à Arqueologia Histórica. Oficina de Livros: Belo Horizonte, 1992. . "Archaeological approaches to New World plantation slavery". In: SCHIFFER, Michael B. (ed.). Archaeological Method and Theory. Tucson: University of Arizona Press, Vol I, 1989:111-154.

PANJA, S. "Mobility strategies and site structure: a case study of Inamgaon". In: Journal of anthropological archaeology, 22 (2): 105-25, 2004.

PARK, Robert. Research in the social sciences: its fundamental methods and objectives. New York: Macmillan, 1929.

PENIN, André S. Academia, Contrato e Patrimônio. Visões distintas da mesma disciplina. Tese (Doutorado). MAE/USP. 2010.

PEREIRA, Astrojildo. "Rui Barbosa e a escravidão". In: Ensaios históricos e políticos. São Paulo, Alfa/Ômega, 1979. 
PETRONE, Pasquale. A Baixada do Ribeira. Tese (Doutorado). Depto de Geografia FFLCH-USP. 1966.

PIKIRAYI, Innocent. Gold, Black Ivory an House of Stone: historical archaeology in Africa. In: HALL, M. \& SILLIMAN, S. W. (ed.). Historical Archaeology. Blackwell Studies in Global Archaeology 9. Massachusetts, Oxford and Carlton: Blackwell Publishing, pp. 230-250, 2006.

POLITIS, Gustavo. "Tendencias de La Etnoarqueología en América Latina". In: POLITIS, G. G. \& PERETTI, R. D. (Ed.). Teoría Archaeológica en América del Sur. Olavarría, 2004.

PRICE, Richard. "Palmares como poderia ter sido". In.: REIS, J.J. \& GOMES, F. S. Liberdade Por um Fio. São Paulo: Cia das Letras, 1996: 52-59. . (org). Maroon societies: rebel slave communities in the Americas. Baltimore: Johns Hopkins University Press, 1987.

PYBURN, Anne. "Uma questão nada simples". In: Patrimônio Arqueológico: o desafio da preservação. Revista do Patrimônio Histórico e Artístico Nacional. Brasília, no. 33, pp. 25-35: 2007.

QUEIROZ, Renato da S. "Essa Terra é Santa, essa terra é nossa: a comunidade quilombola de Ivaporanduva e o direito de propriedade". In: ITESP. Quilombos em São Paulo. Tradições, direitos e lutas. SP, 1997: 105-116.

RAMOS, Arthur. As culturas negras no novo mundo: o negro brasileiro. São Paulo: Companhia Editora Nacional, 1946.

. A cultura negra no Brasil. São Paulo, Rio de Janeiro, Recife, Porto Alegre: Nacional, 1942.

. O negro brasileiro: etnografia religiosa. São Paulo: Nacional, 1940.

. "Prefácio" In.: FREIRE, Gilberto et all. Novos estudos Afrobrasileiros: trabalhos apresentados ao $1^{\circ}$ Congresso Afro-Brasileiro do Recife. Rio de Janeiro: Civilização Brasileira, 1937. 
RANGER, Terence. “A Invenção da Tradição na África Colonial”. In: HOBSBAWM, Eric \& RANGER, Terence (org). A Invenção das Tradições. Rio de Janeiro: Paz e Terra, 1997.

RANFREW, Colin \& BAHN, Paul. Archaeology: theories, methods and practice. New York, N.Y.: Thames and Hudson, 1991.

ROSA, João H. Entre alagados e penhascos: o ouro da liberdade nas resistências quilombolas do século XVIII na capitania do Mato Grosso, região mineradora guaporeana. Dissertação. São Paulo: MAE/USP, 2008.

ROWLANDS, Michel, "Black identity and sense of past in Brazilian national culture" In: FUNARI, P. P. A., HALL, M. e JONES, S. (orgs). Historical Archaeology - Back from the Edge, Routledge, Londres, 1999.

RUBERTONE, Patricia. E. “Arqueologia, colonialismo e América nativa do século XVII: avanços de interpretações alternativas". In: Conflict in the archaeology of living traditions. Ed. Robert Layton, 1994.

SALES, Renato J. R. \& MOREIRA, André C. C. "Reserva Extrativistas no Complexo Estuarino-Lagunar de Iguape e Cananéia - Domínio Mata Atlântica". Série: Documentos e Relatórios de Pesquisa, no. 22, São Paulo, Núcleo de Apoio à Pesquisa sobre Populações Humanas e Áreas Úmidas Brasileiras da Universidade de São Paulo (NUPAUB), 1996.

SANTOS, José Maria dos. Os republicanos paulistas e a abolição. São Paulo, Nacional, 1942.

SANTOS, Milton. "O Retorno do Território". In: SANTOS, M.; SOUZA, MARIA A. A. de; SILVEIRA, MARIA L. (org.). Território, Globalização e Fragmentação. Editora Hucitec. Ass. Nacional de Pós-graduação e Pesquisa em Planejamneto Urbano e Regional. São Paulo, SP, pp. 15-20:1994.

SCATAMACCHIA, M. C. M. Arqueologia do Baixo Vale do Ribeira: índios, portugueses e espanhóis. Tese de livre docência no MAE/USP. São Paulo, 2011. 
. “Os primeiros habitantes do baixo vale do Ribeira".

In: DIEGUES, A.C. Enciclopédia caiçara. Vol. I Ed. Hucitec-NUPAUB-CEC/USP, São Paulo, 91-104, 2004.

Cadastramento e divulgação dos sítios arqueológicos

do baixo Vale do Ribeira. In: Revista de Arqueologia. São Paulo, v.8 , n.1 , p.167-71, 1994.

- A tradição policrônica no leste da América do sul evidenciada pela ocupação Guarani e Tupinambá: fontes arqueológicas e etnohistóricas. Tese. USP, 1990.

SCHADEN, Egon. “A origem dos homens, o dilúvio e outros mitos kaingang”. In: Revista de Antropologia. São Paulo, v.1, nº 2, pp. 139-141, dez 1953.

SCHIFFER, M. B. Formation process of the archaeological Record. Albuquerque: University of New Mexico Press, 1987.

Archaeological context and Sistemic context. In: American antiguity, 37 (2), 1972:156-65.

SCHMIDT, Afonso. A marcha. São Paulo, Anchieta, 1941.

SERRANO, Carlos M. H. "Ginga, A Rainha quilombola de Matamba e Angola", In.: Revista USP. Dossiê Povos Negros - 300 anos. SP: USP, CCS, 1989.

SHEPHERD, Nick. "When the hand that holds the trowel is black... Disciplinary practices of self-representation and issue of native labour in archaeology". In: Jornal of Social Archaeology, 7(3):286-301. 2003.

SILLIMAN, Stephen. "Agency, practical politics and the archaeology of culture contact". In: Journal of Social Archaeology, Vol 1(2). London: Copyright, PP. 190209:2001.

SÍLVA, Fabíola A. "Arqueologia e etnoarqueologia na Aldeia Lalima e na Terra Indígena Kayabi: reflexões sobre Arqueologia Comunitária e Gestão do Patrimônio Arqueológico". In.: Revista do Museu de Arqueologia e Etnologia, São Paulo, 19: 205-219, 2009 
. "Mitos e arqueologia: a interpretação dos Assurini do Xingu sobre os vestígios arqueológicos encontrados no parque Kuatinemu - Pará" In: Horizontes Antropológicos. Porto Alegre, v.8, n.18, pp: 1-7, dez., 2002.

. As tecnologias e seus significados: um estudo da cerâmica dos assuriní do Xingú e da cestaria dos Kayapó-xikrin sob uma perspectiva etnoarqueológica. Tese (Doutorado) - Faculdade de Filosofia e Ciências Humanas da Universidade de São Paulo. Departamento de Antropologia. São Paulo, 2000.

SILVA, Fabíola; BESPALEZ, Eduardo; STUCHI, Francisco; POUGET, Frederick. Arqueologia, Etnoarqueologia e História Indígena. Um Estudo da Trajetória de Ocupação Indígena em Territórios do Mato Grosso e Mato Grosso do Sul. T.I. Kayabi e a Aldeia Lalima. Relatório Científico FAPESP. São Paulo, 2008.

SINGLETON, T. "Slavery and Spatial Dialetics on Cuban Coffee Plantations". In: World Archaeology, (33):1, 98-114, 2001.

SINGLETON, T \& BOGRAD, M. D. The Archaeology of Africa Diaspora in the Americas. Tuczon, AZ: Society for Historical Archaeology, 1995.

SMITH, Claire \& WOBST, H. Martin. "Descolonizing archaeological theory and practice”. In: Indigenous archaeologies. London: Routledge, 2007, pp. 5-17.

SMITH, Laurajane. The Use of Heritage. Routledge: New York, NY. 2006.

"Towards a Theoretical Framework for Archaeological Heritage Management". In.: FAIRCLOUGH, Graham; HARRISON, Rodney; JAMESON Jr., John; SCHOFIELD, John. (eds.). The Heritage Reader. Routledge, Taylor \& Francis Group, London \& New York, pp. 62-71: 2008.

SMITH, Laurajane \& WALTERTON, Emma. Heritage, Communities and Archaeology. Duckworth Debates in Archaeology: London. 2011.

SODRÉ, Muniz. O terreiro e a cidade: a forma social negro-brasileira. Petrópolis, Vozes, 1988.

SOUSA, Gabriel S. Tratado descritivo do Brasil em 1587. São Paulo:Cia. Ed. Nacional: EDUSP, 1971. 
SUGUIO, Kenitiro. "Stratigraphyn of the Iguape-Cananéia". In.: Boletim do Instituto de Geociência. São Paulo, V.4, pag. 1-20, 1973.

STADEN, Hans. Duas Viagens ao Brasil. EDUSP, São Paulo/ Ed. Itatiaia, Belo Horizonte, 1979.

STEWARD, Julian. Theory of Culture Change. University of Illinoi Press, Urbana, 1955.

STEWARD, Andrew M.; KEITH, Darren; SCOTTIE, Joan. Caribou crossings and cultural meaning: placing traditional knowledge and archaeology in context in an Inuit landscape. In: Journal of Archaeological Method and Theory, 11 (2), 2004:183212.

SYMANSKI, L. C. P. Espaço Privado e Vida Material em Porto Alegre no Século XIX. Porto Alegre: EDIPUCRS, 1998. (Coleção Arqueologia 5).

. "O domínio da tática: Práticas religiosas de origem africana nos engenhos de Chapada dos Guimarães (MT)". In. Vestígios: Revista Latino-Americana de Arqueologia Histórica, v.1, n.2, pp. 9-36, 2007.

SYMANSKI, L. C. P; SOUZA, M. A. T. de. "O Registro Arqueológico dos Grupos Escravos: Questões de Visibilidade e Preservação". In: Revista do Patrimônio Histórico e Artístico Nacional, 2007 (33): 215-242.

TAUNAY, Afonso d'E. História Geral das Bandeiras Paulistas. São Paulo: Imprensa Oficial do Estado, 11 volumes, 1948.

THOMAS, Brian W. "Power and Community: The Archaeology of Slavery at the Hermitage Plantation”. In: American Antiquity, (63): 4, 531-551. 1998.

THOMPSON, Paul. A Voz do Passado: história oral. Rio de Janeiro, RJ: Paz e Terra. 1992.

TILLEY, Christopher. "Space, Place, Landscape and Perception: Phenomenological Perspectives". In: TILLEY, C. (Ed.). A Phenomenology of Landscape. Berg, Oxford. 1994: 7-34. 
TRIGGER, Bruce G. História do Pensamento Arqueológico. São Paulo:Odysseus Editora, 2004.

TULLY, Gemma. "Community Archaeology: general methods and standars of practice". In: Public Archaeology, 6(3) 2007:155-187.

UCHÕA, Dorath P.; GARCIA, Caio D. R. "Cadastramento dos sítios arqueológicos da baixada Cananéia-Iguape, litoral sul do estado de São Paulo, Brasil”. In.: Revista de Arqueologia, Museu Paraense Emílio Goeldi, Belém, Pará, v. 1, n.1, 1983.

VALENTIM, Agnaldo. Uma civilização de arroz: agricultura, comércio e subsistênca no Vale do Ribeira (1800-1880). Tese. São Paulo: USP, 2006.

WALDMAN, Maurício. "Africanidade, Espaço e Tradição: a topologia do imaginário africano tradicional na fala griot de Sundjata Keita do Mali”. In.: África - Revista do Centro de Estudos Africanos da USP, São Paulo (SP), Brasil, v. 20/21, p. 219-268, 2000.

WAHLGREN, K.H. \& SVANBERG, F. "Pulic Archaeology as renewer of the historical museum”. In: Public Archaeology, (7)4:241-258. 2008.

WHITRIDGE, Peter. Landscape, house, bodies, things: place and the archaeology of Inuit imaginaries. In: Journal of Archaeological Method and Theory, 11 (2), 2004:213-250.

WILLEY, Gordon. "Prehistoric Settlement Patterns in the Virú Valley, Peru". In: Bulletin, $\mathrm{n}^{\circ} .155$, Bureau of American Etnology, Washington, DC. 1953.

YENTSCH, A. E. A Chesapeake Family and Their Slaves: A Study in Historical Archaeology. Cambridge: Cambridge U. P. 1994.

ZEDEÑO, Maria N. Landscapes, land use, and the history of territory formation: an example from puebloan southwest. In: Journal of archaeological method and theory. 4 (1), 63-103: 1997.

. "On What People Make of Places: A behavioral cartography".

In: Bowser, B. J. \& Zedeño, M. N. (org). The Archaeology of the Meaningful Places. University of Utah Oress, Salt Lake city. pp.97-111: 2009. 
. "The archaeology of Territory and Territoriality". In.: DAVID,

B. and THOMAS, J. The Hadbook of Landscape Archaeology (World Archaeological Congress Research), edited by Left Coast Press, Walnut Creek, California, pp 210-217: 2008.

ZEDEÑO, Maria \& BOWSER, Brenda. "The Archaeology of the Meaningful Places". In: Bowser, B. J. \& Zedeño, M. N. (org). The Archaeology of the Meaningful Places. University of Utah Oress, Salt Lake city. pp.1-14: 2009. 


\section{RELATÓRIOS:}

TURATTI, M. Cecília M. "Relatório Técnico-Científico sobre os Remanescentes da Comunidade de Quilombo de Mandira/ Cananéia-SP”. Fundação Instituto de Terras do Estado de São Paulo “José Gomes da Silva” (ITESP). São Paulo-SP,fevereiro, 2002.

ZANETTINI, Paulo. Relatório Final do Projeto Fronteira Ocidental: Arqueologia e História. Vila Bela da Santíssima Trindade/MT. Fase 1, 2, 3 e 4. Realização Zanettini Arqueologia. Financiamento: FAPEMAT/ Governo do Estado do Mato Grosso Secretaria de Estado da Cultura. Etapas de 2002, 2004, 2006 e 2007.

\section{SITES:}

Ministério da Cultura:

http://www.cultura.gov.br/culturaviva/ponto-de-cultura

Globo nordeste:

http://pe360graus.globo.com/noticias/cidades/estradas/2010/08/19/NWS,519097,4,253, NOTICIAS, 766-OBRA-TRANSNORDESTINA-ESBARRA-PROTESTOQUILOMBOLAS.aspx 
ANEXO 1:

MAPAS 


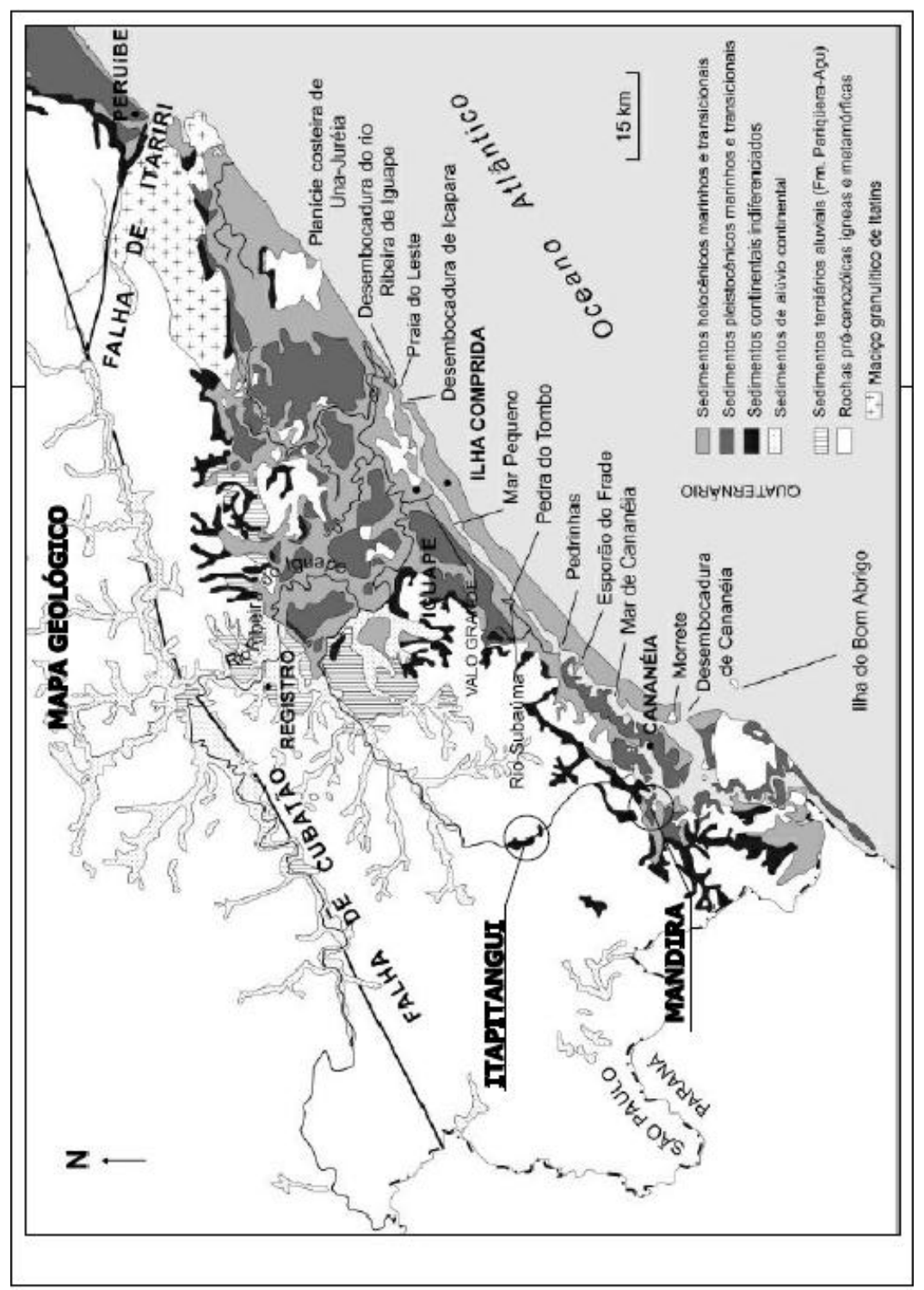

2 


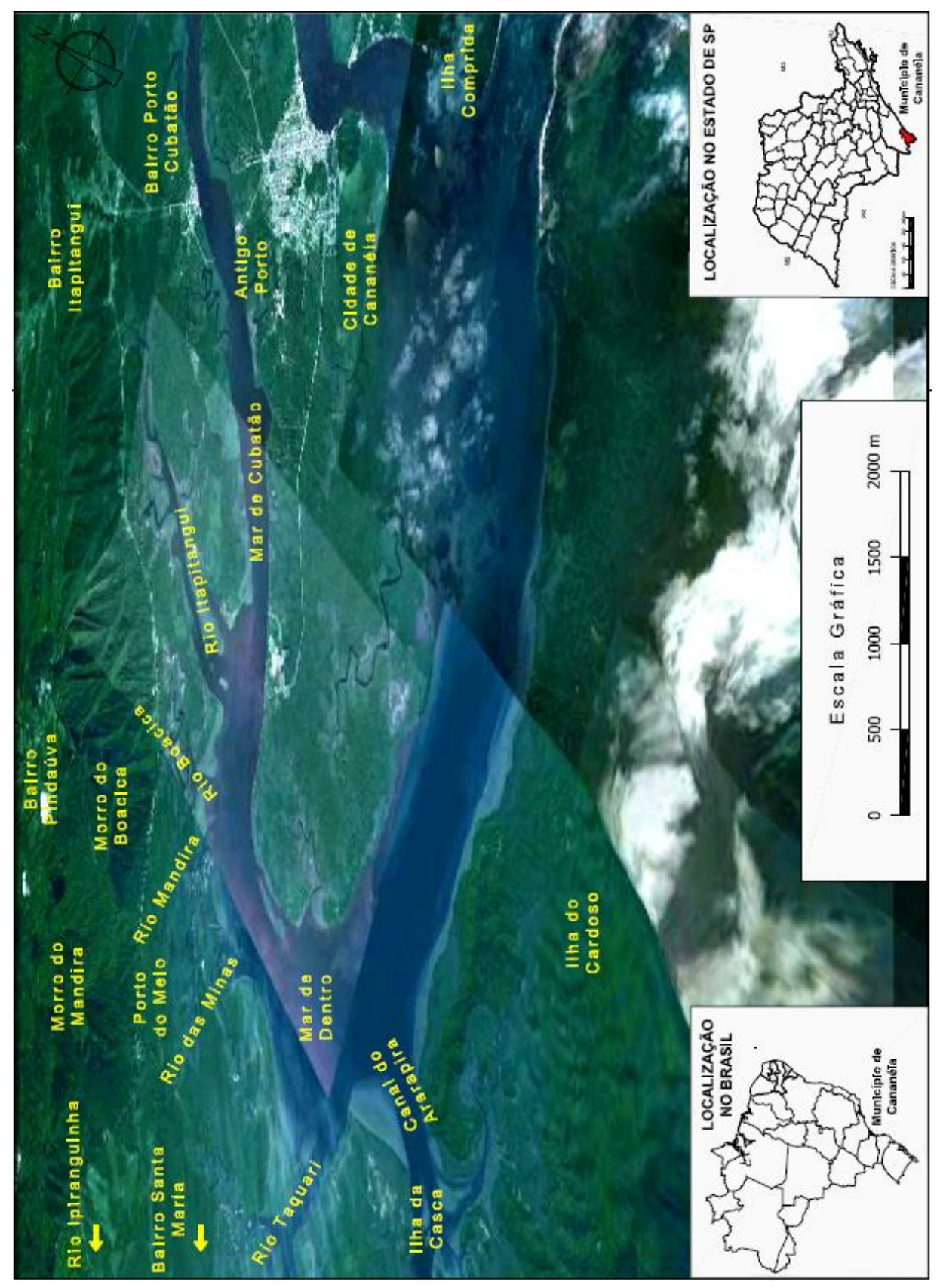

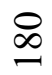




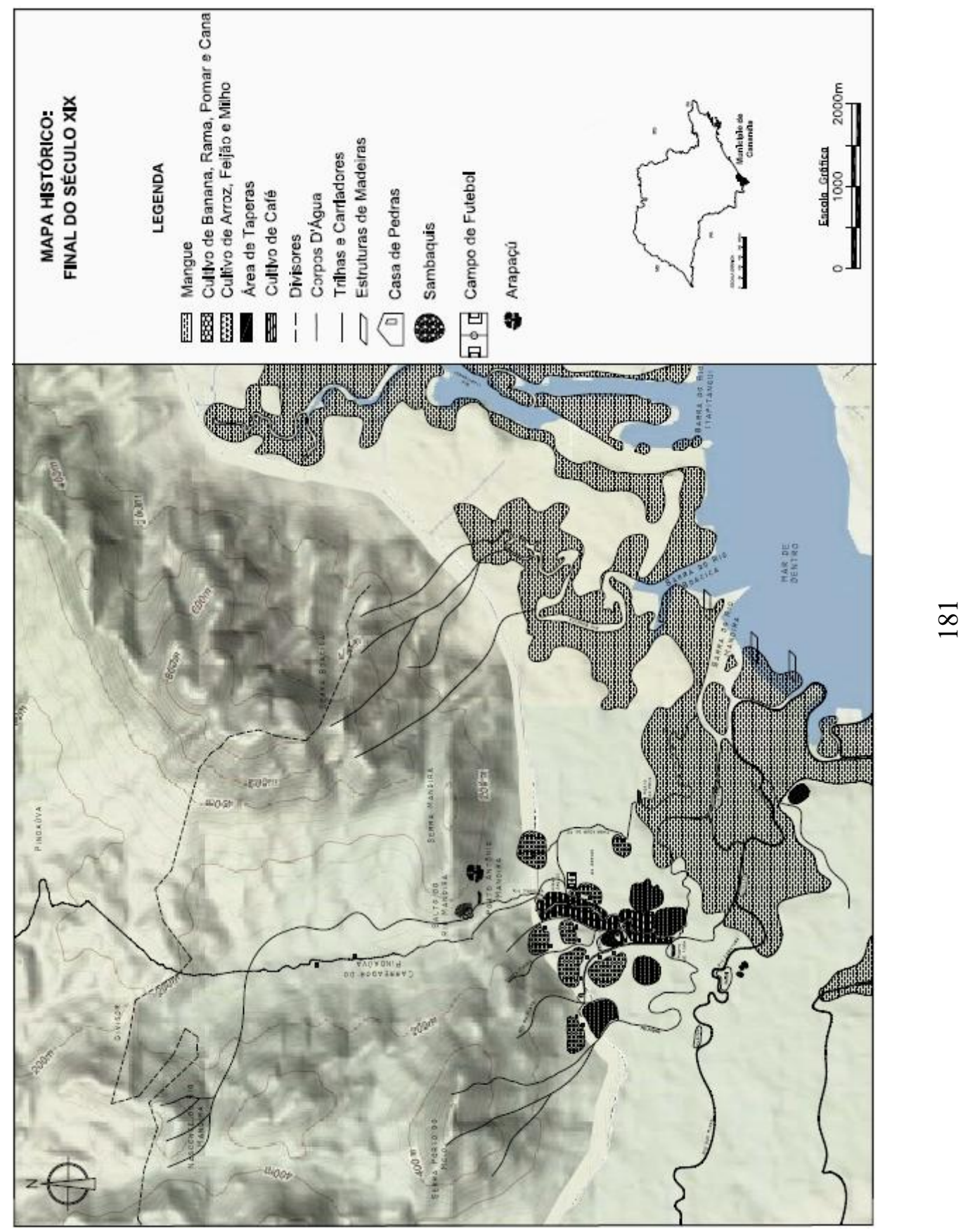




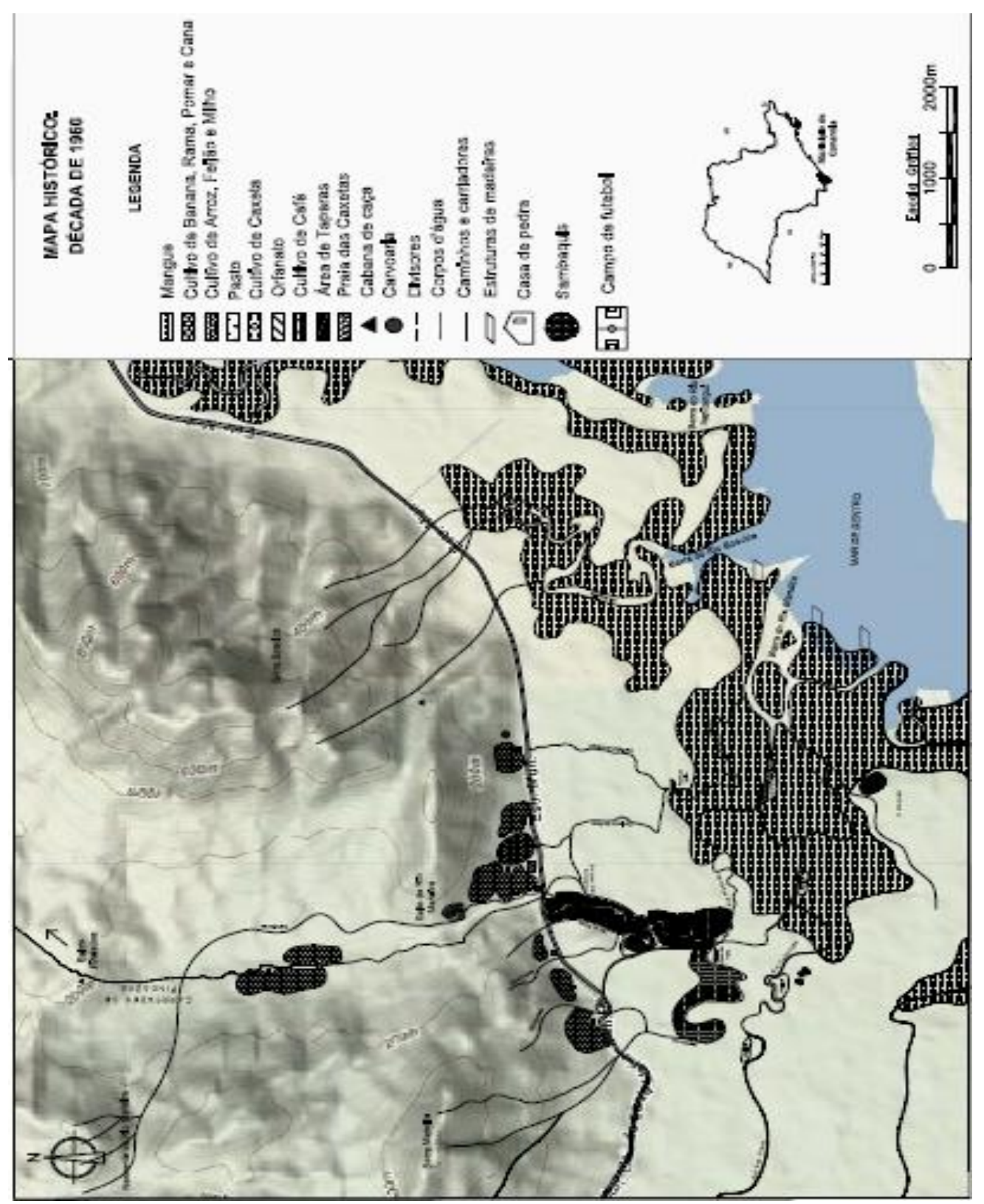

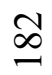




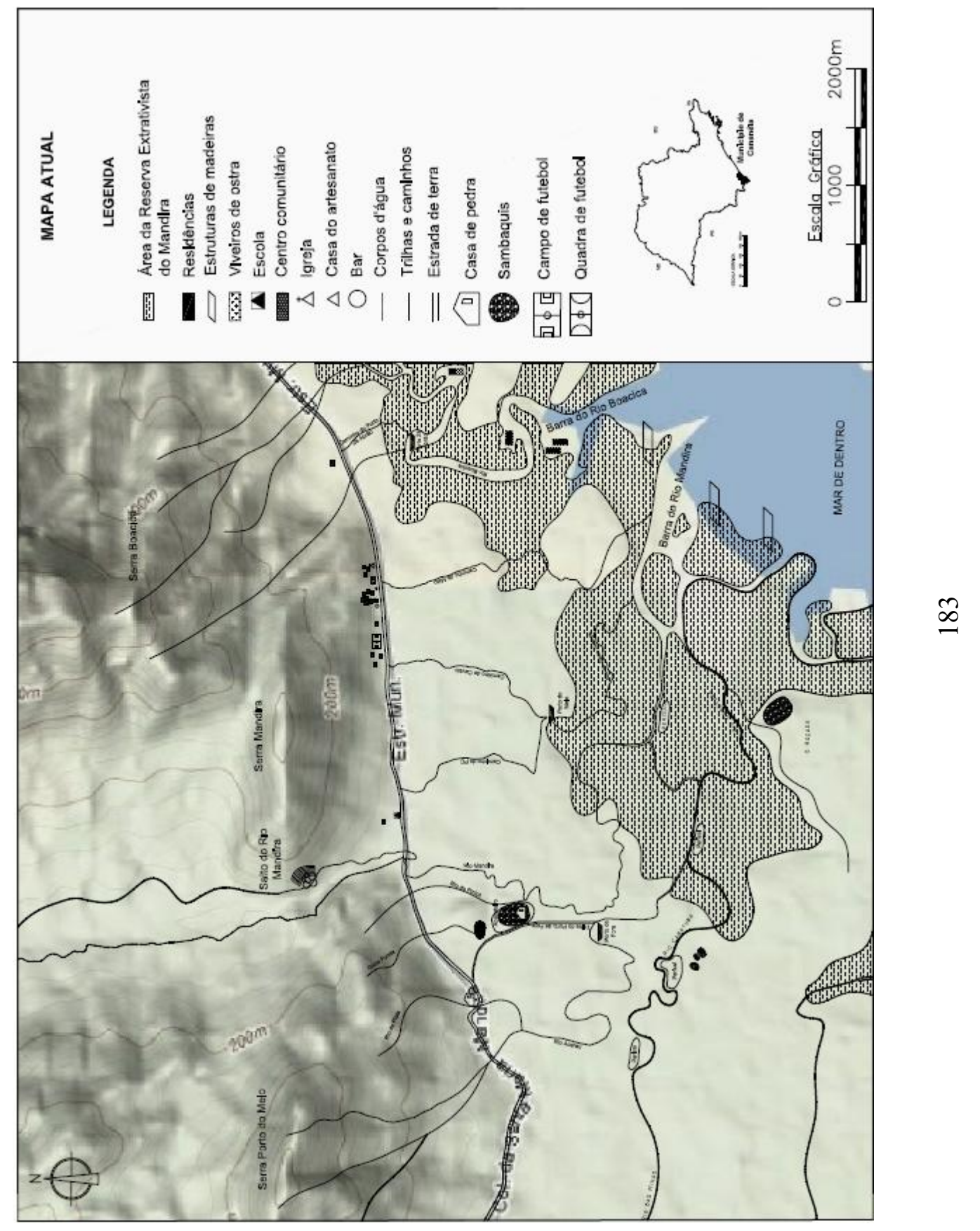


ANEXO 2:

DOCUMENTOS 


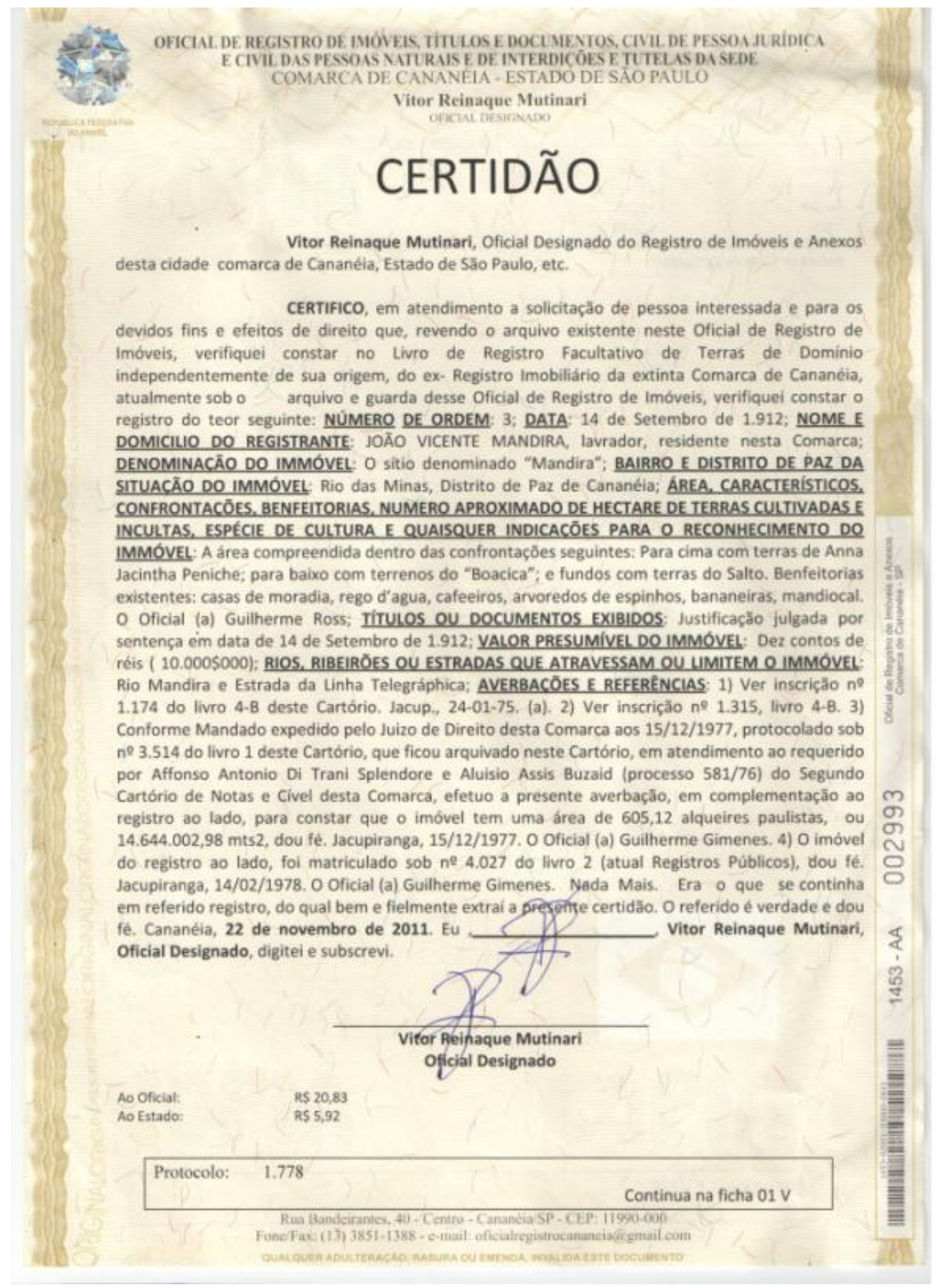




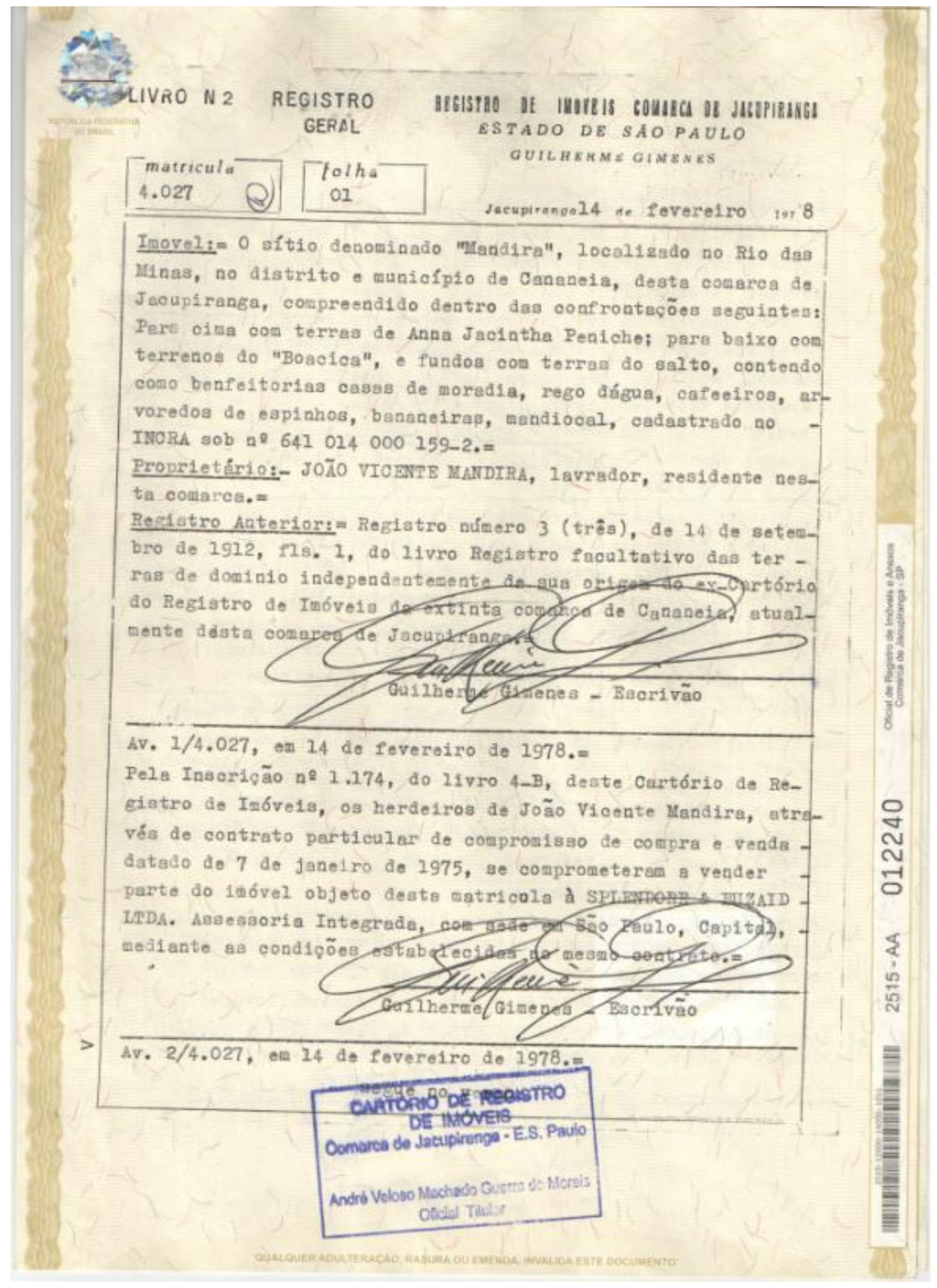




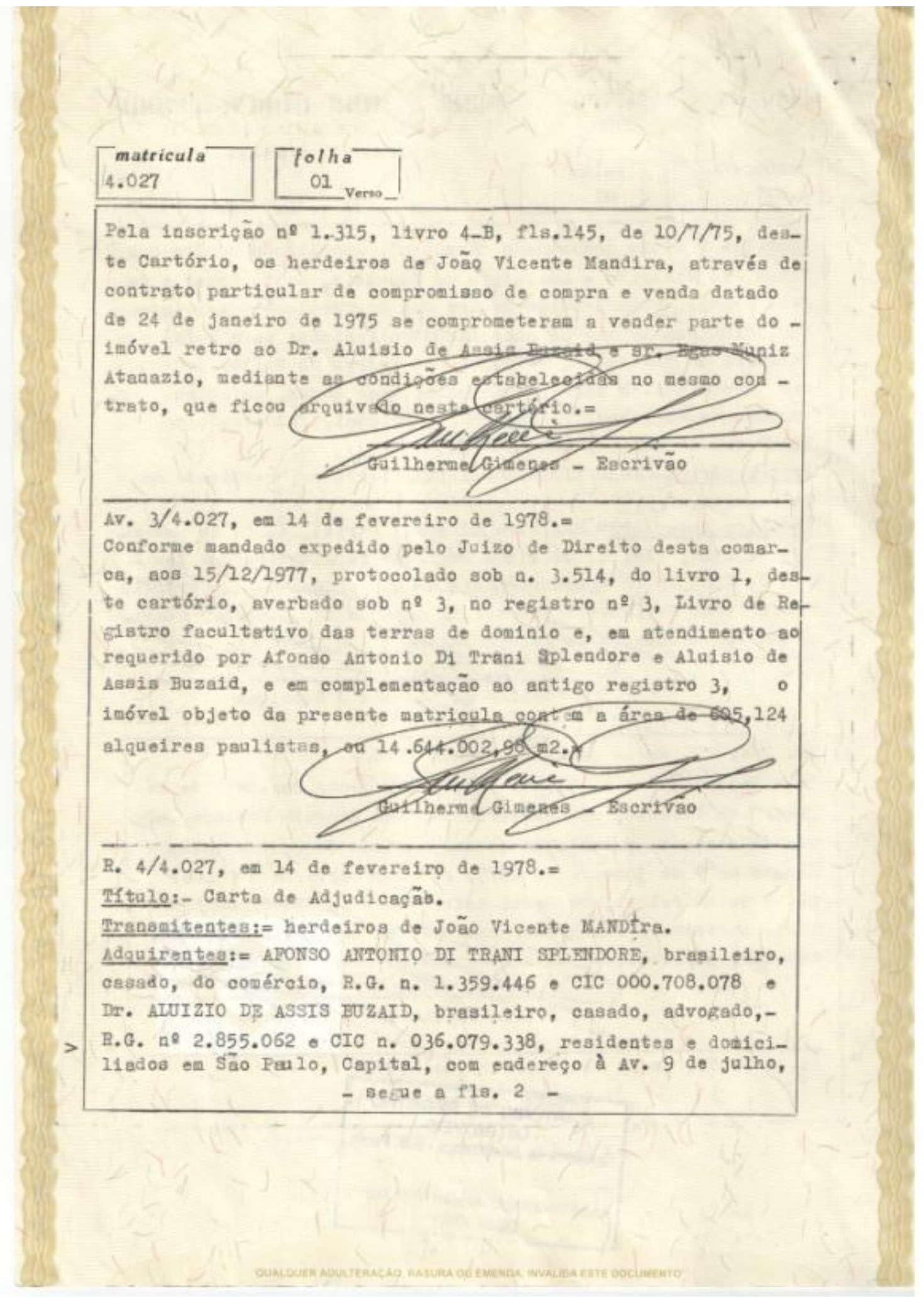




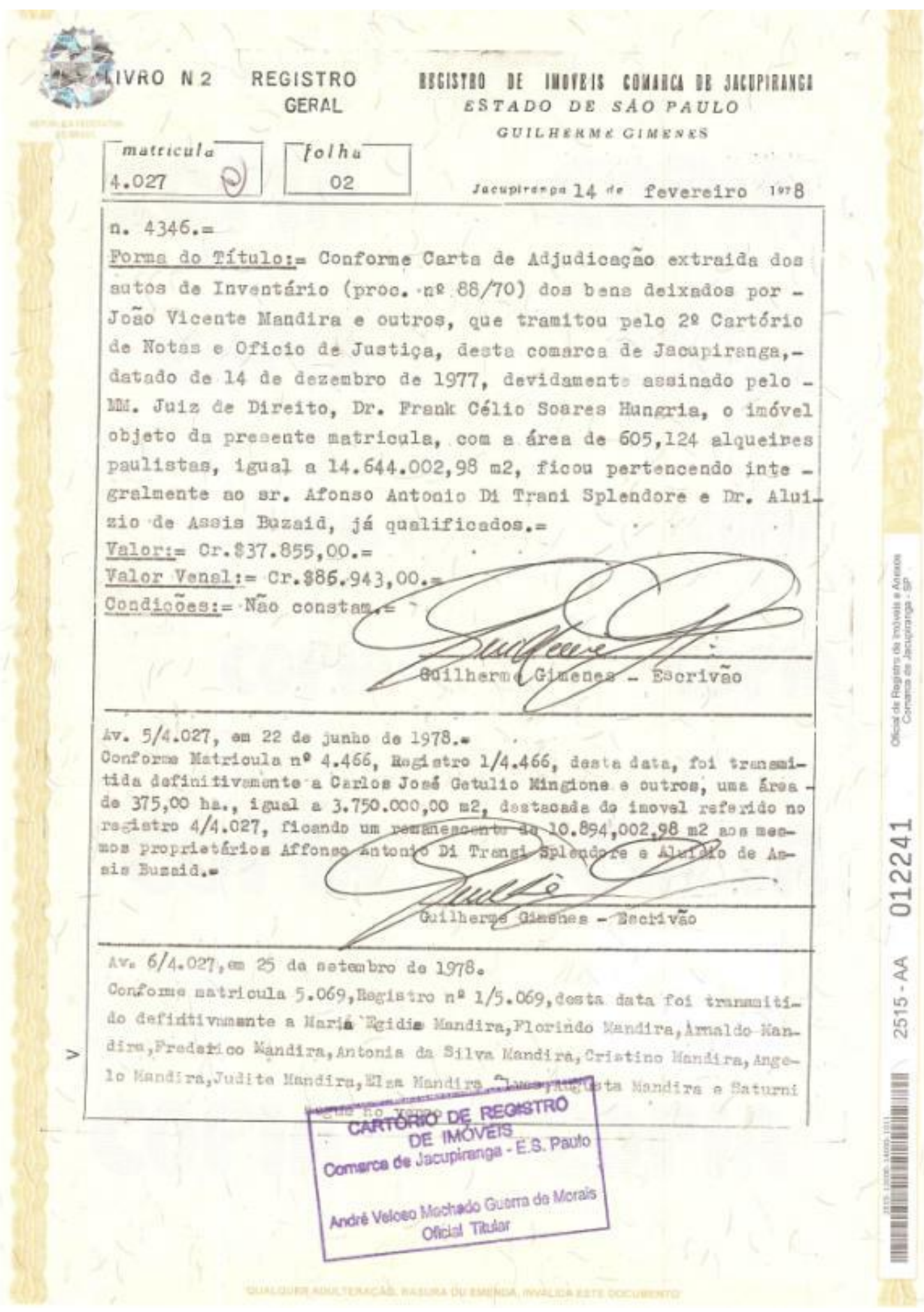




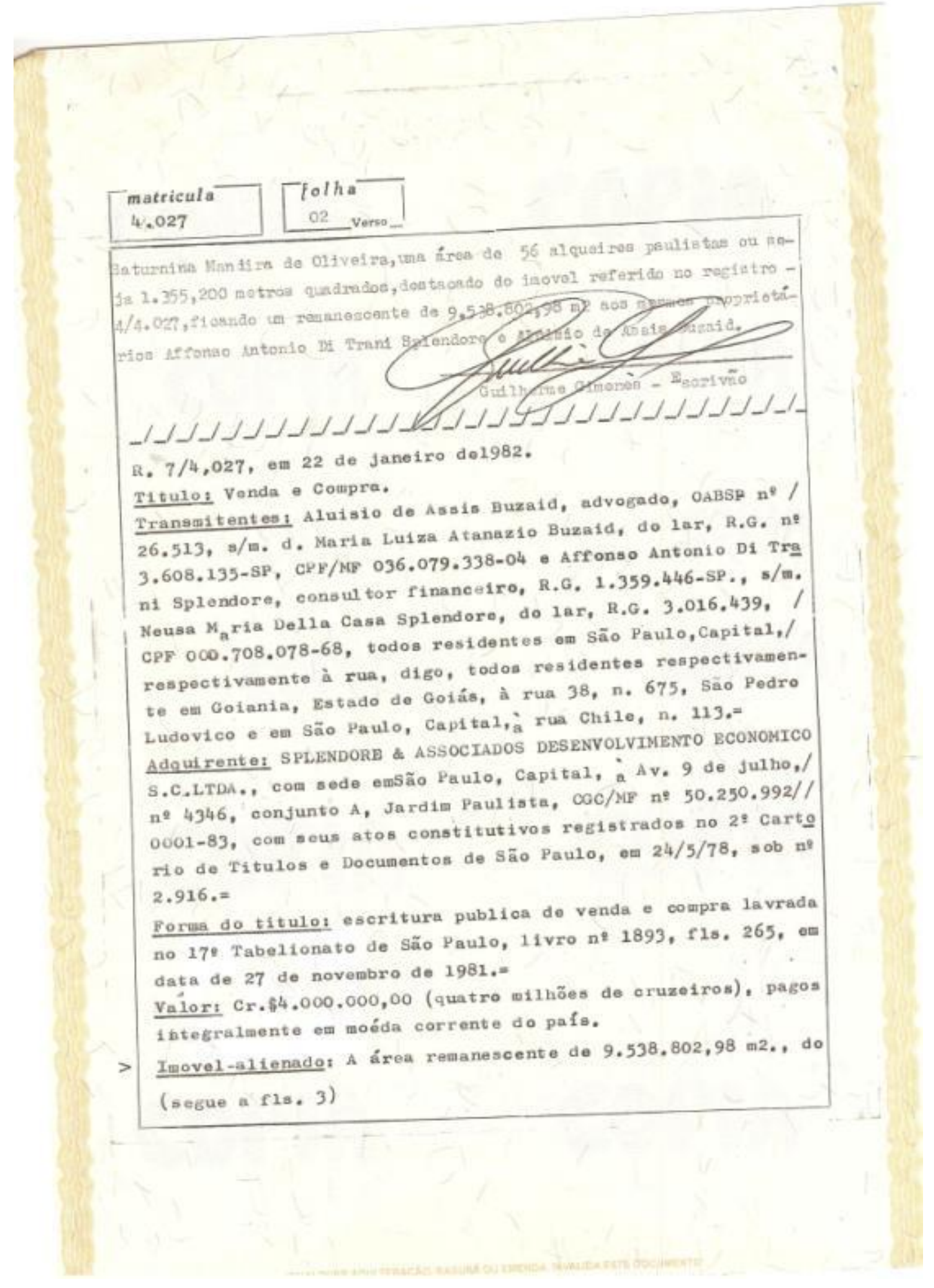




\section{REGISTRO N.: 2 REGISTRO DE IMOVEIS COMARCA DE JACUPIRANGA
GERAL}

GUILHERME GIMENES - Eactivke
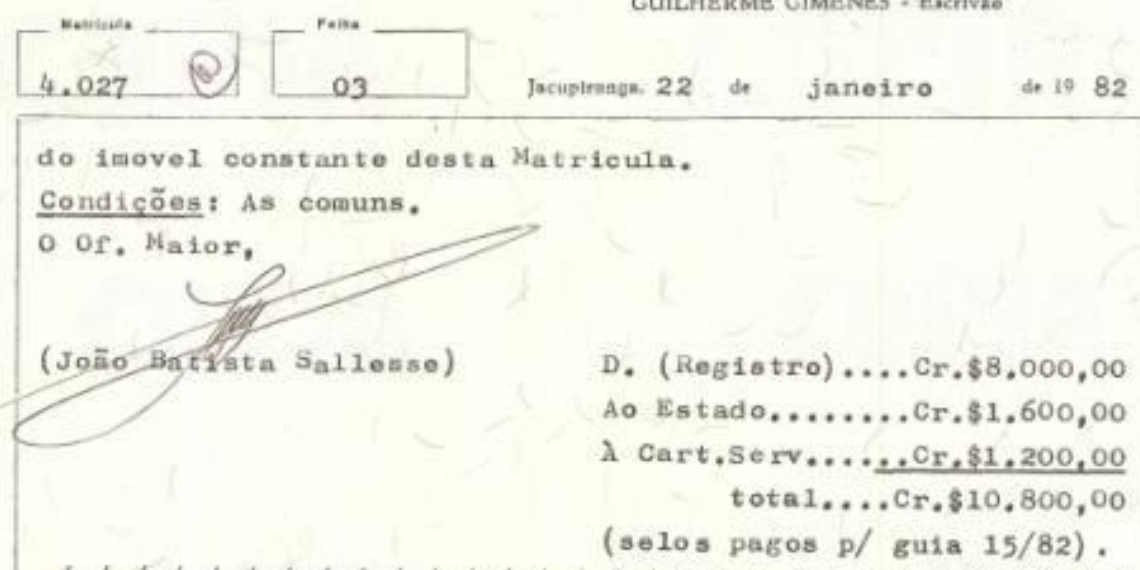

do imovel constante desta Matrioula.

Condições: As comuns.

(Joäo Bntîta Sa11esso)

D. (Regiatro) ..... Cr. $\$ 8,000,00$

Ao Estado........... Cr.\$1.600,00

A Cart,Serv......... $81,200,00$

tota1..... Cr.\$10.800,00

(selos pagos p/ guia $15 / 82$ ).

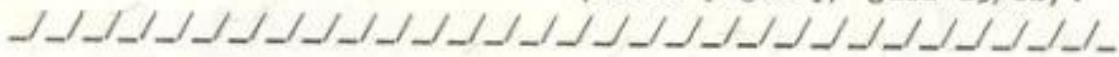
Av. 8/4.027, em 22 de janeiro de 1982 .

Pelo registro 1, Matricula ne 15.505, 12 2, deste Cartorio,foi transmitida uáa f́rea de $1.000,000,00 \mathrm{~m} 2$. 1 gua 1 a 100,00 ha.l para Trepco Desenvolvimento Agrairio Ltda., ficando um remanes cente de $8.538 .802,98 \mathrm{m2}$, à proprietária.

o Or. Maior,

(Joäo Bgfista Sa 11 esso)

O

AV. 09 - Em 16 de junho de 2009

Ref. protocolo n. 44.608 , de 15 de junho de 2009

Procede-se esta averbaçăo para constar que conforme Oficio n. 977/2009 LCK, datado de $1^{\circ}$ de junho de 2009, referente ao Processo n. 118.01.2004.001806-0/000000-000, Controle n. 103/2004, expedido nos autos da açåo penal proposta pela Justiça Pública contra APHONSO SPLENDORE, assinado pela Dra. Barbara Donadio Antunes Chinen, MM. Juiza de Direito da Vara Unica da cidade e Comarca de Cananéia - SP, foi determinado o bloqueio da área remanescente desta matriedla.

\section{Joile Bartista Sallesse - Oticial}

\section{(veroo)}

CAPTORO DE REGISTIRO

DE IMÓVEIS

Comarce do Jacuplronga - E.S. Paulo

André Velone Vachedo Guerra do Morais

Oflcial Titulas 


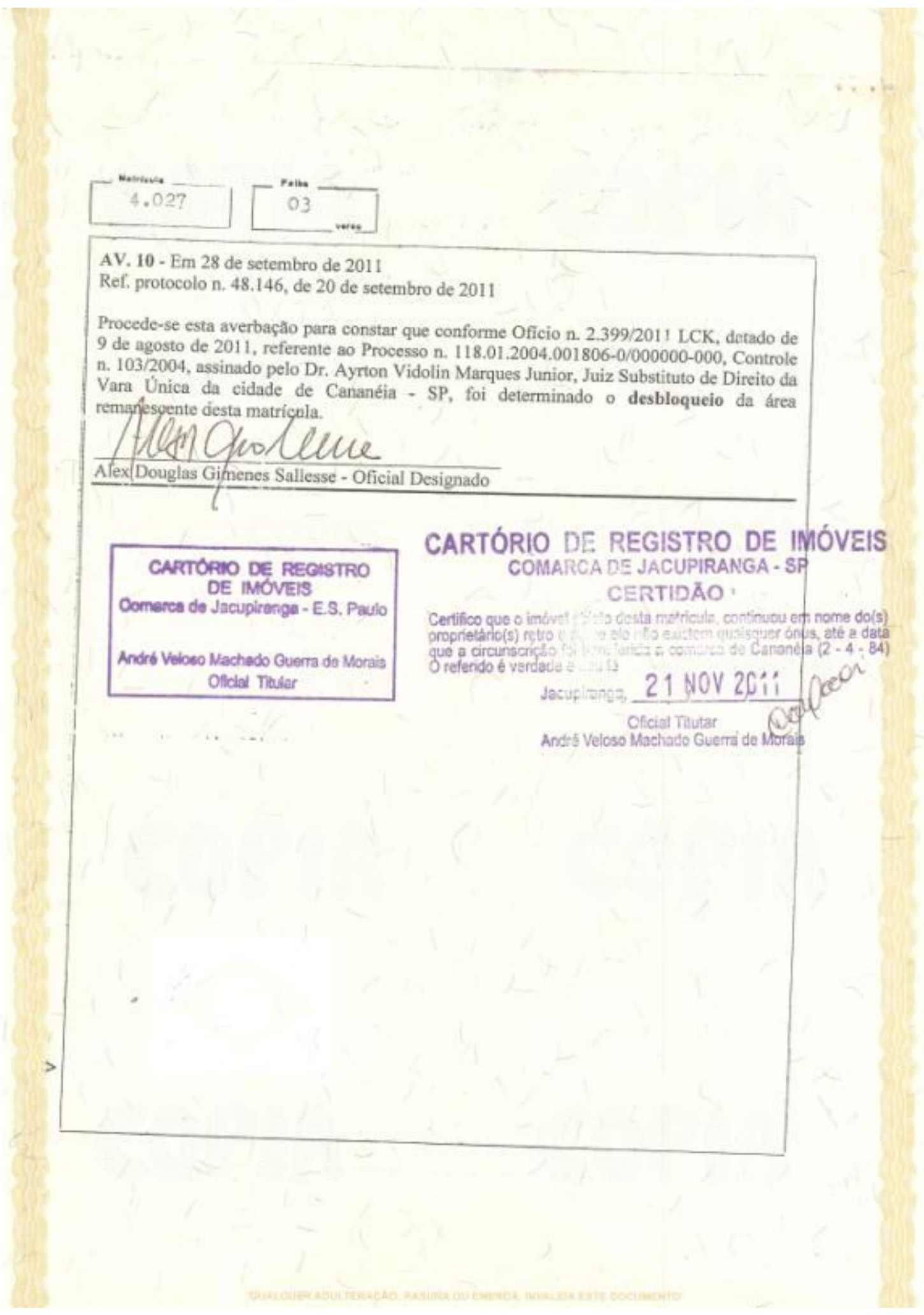




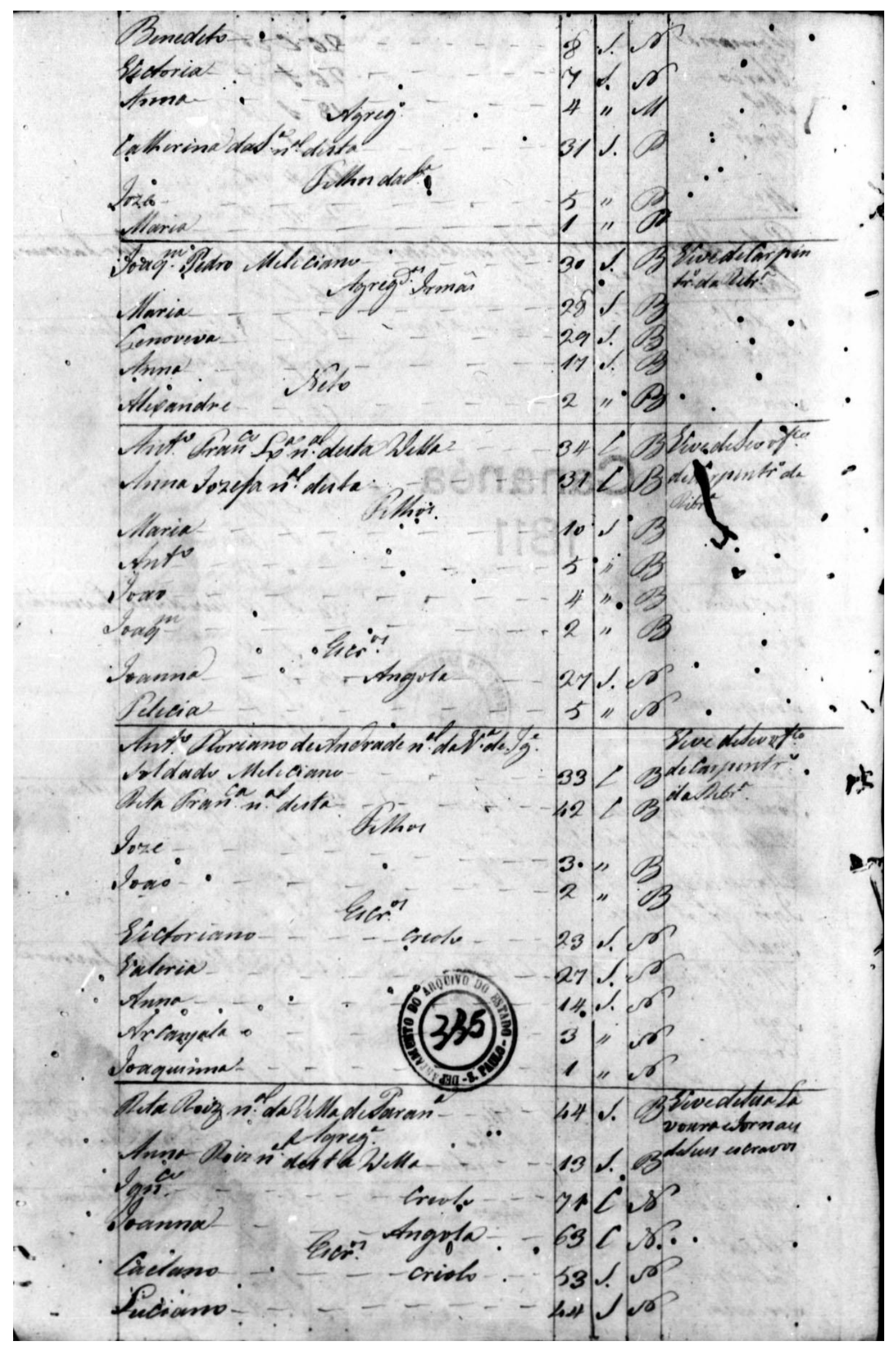




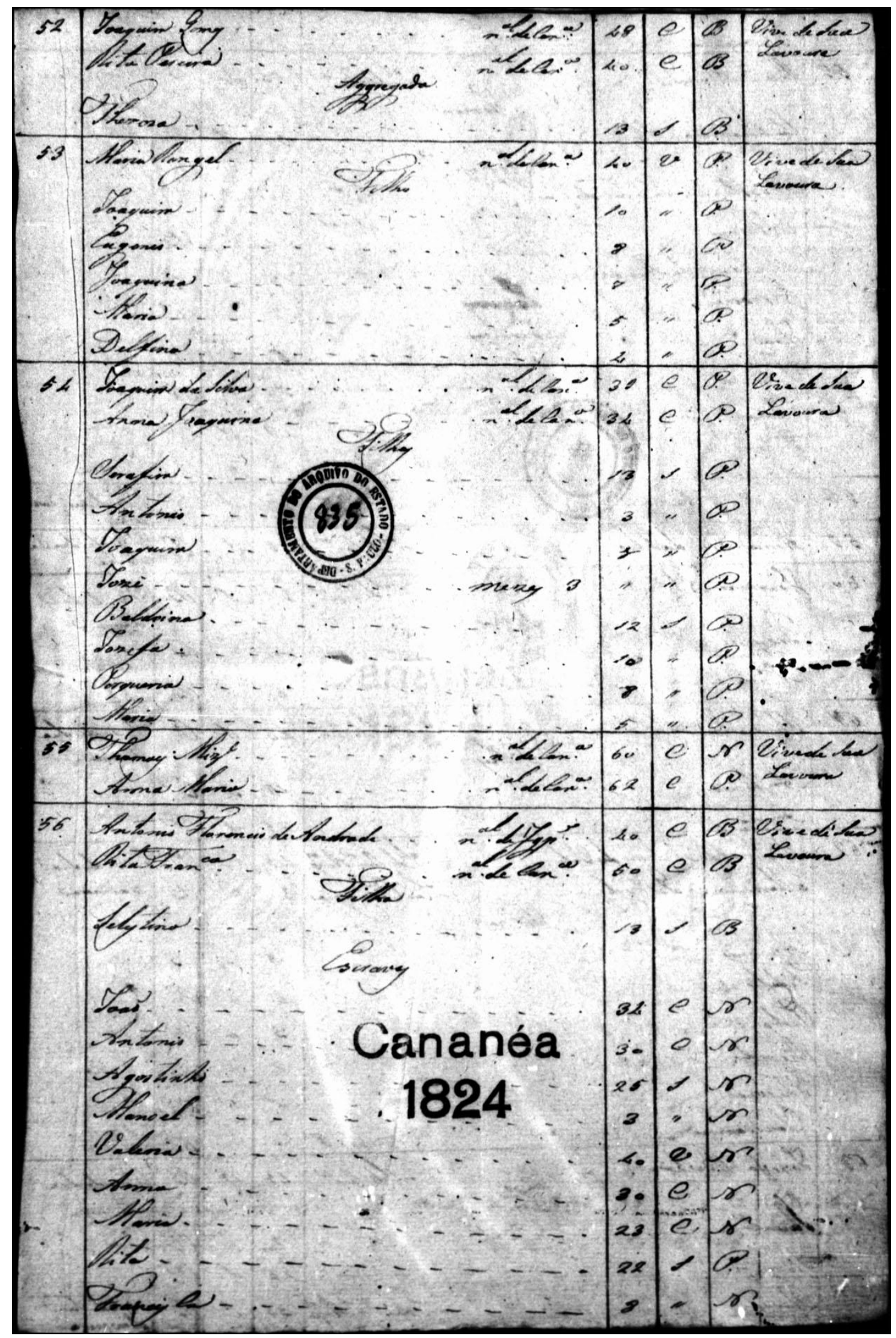




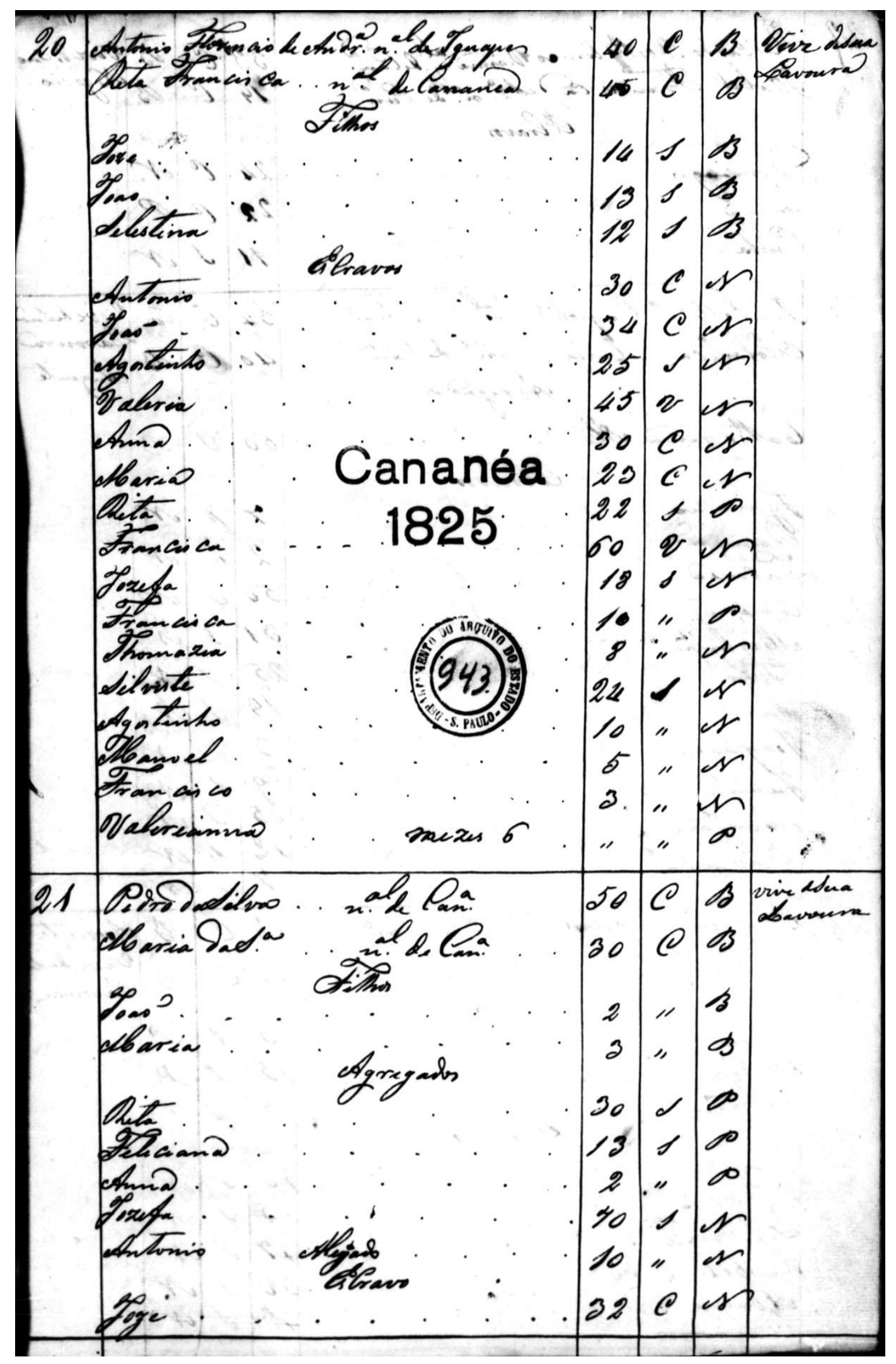




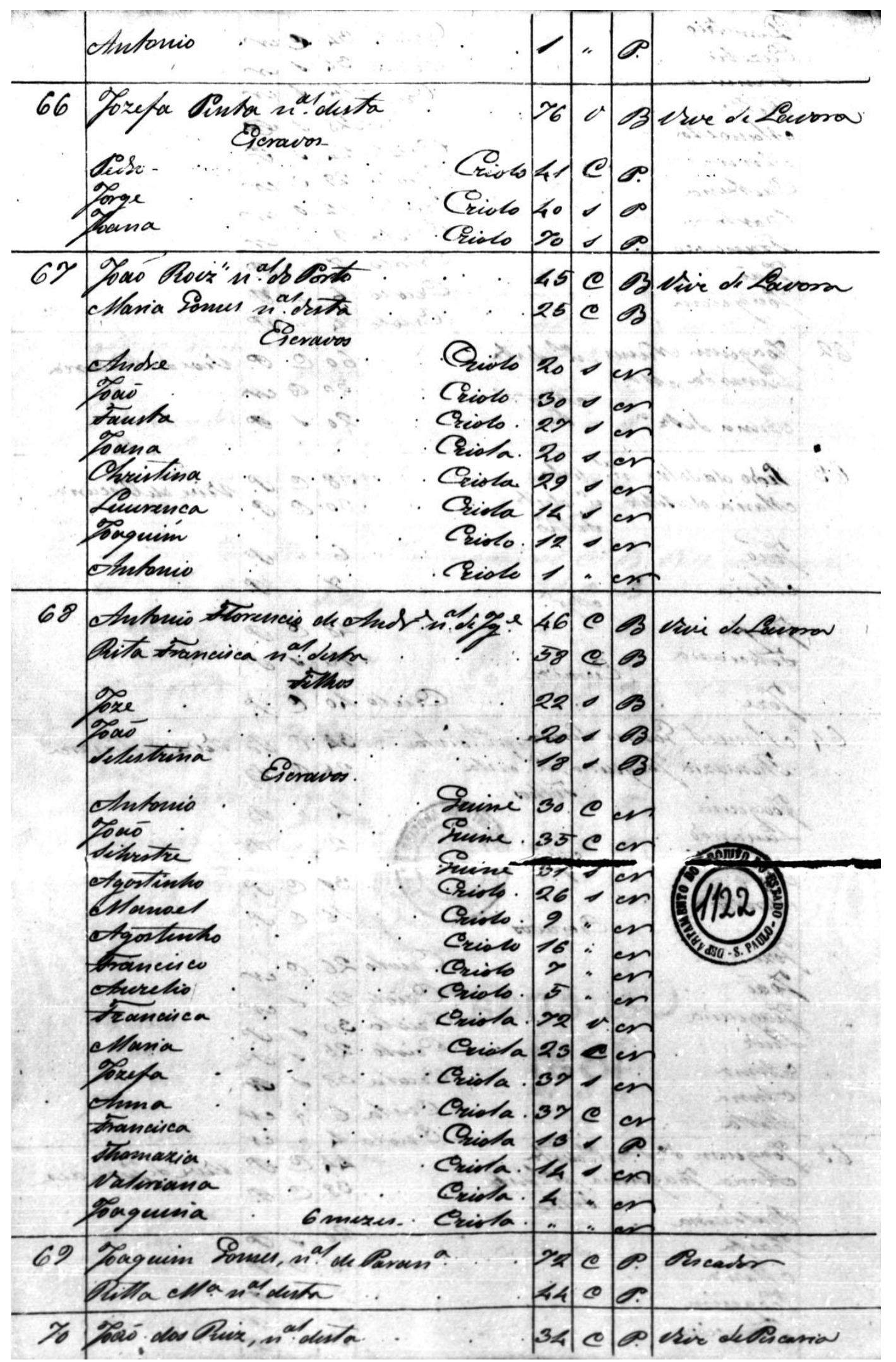




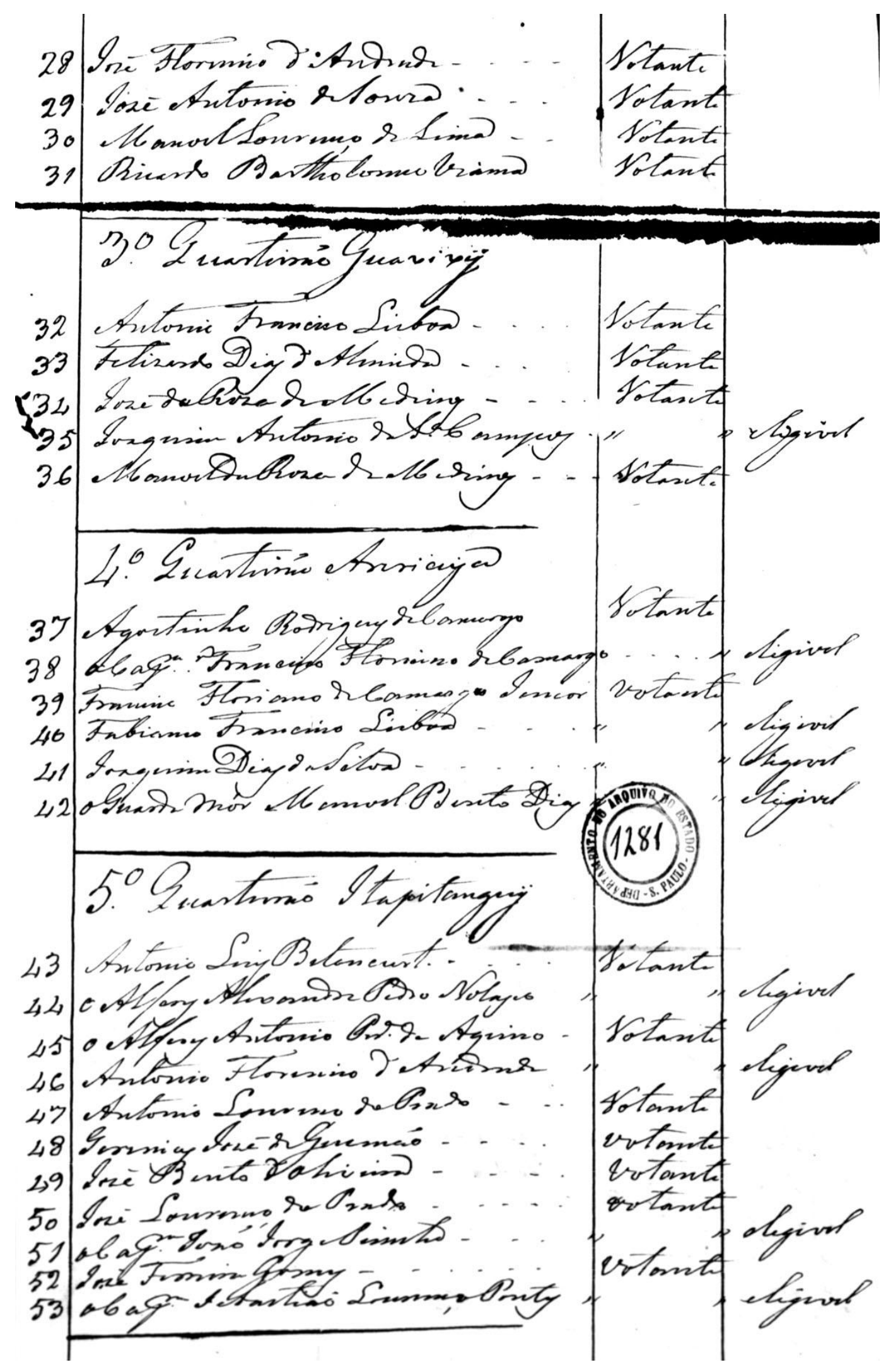




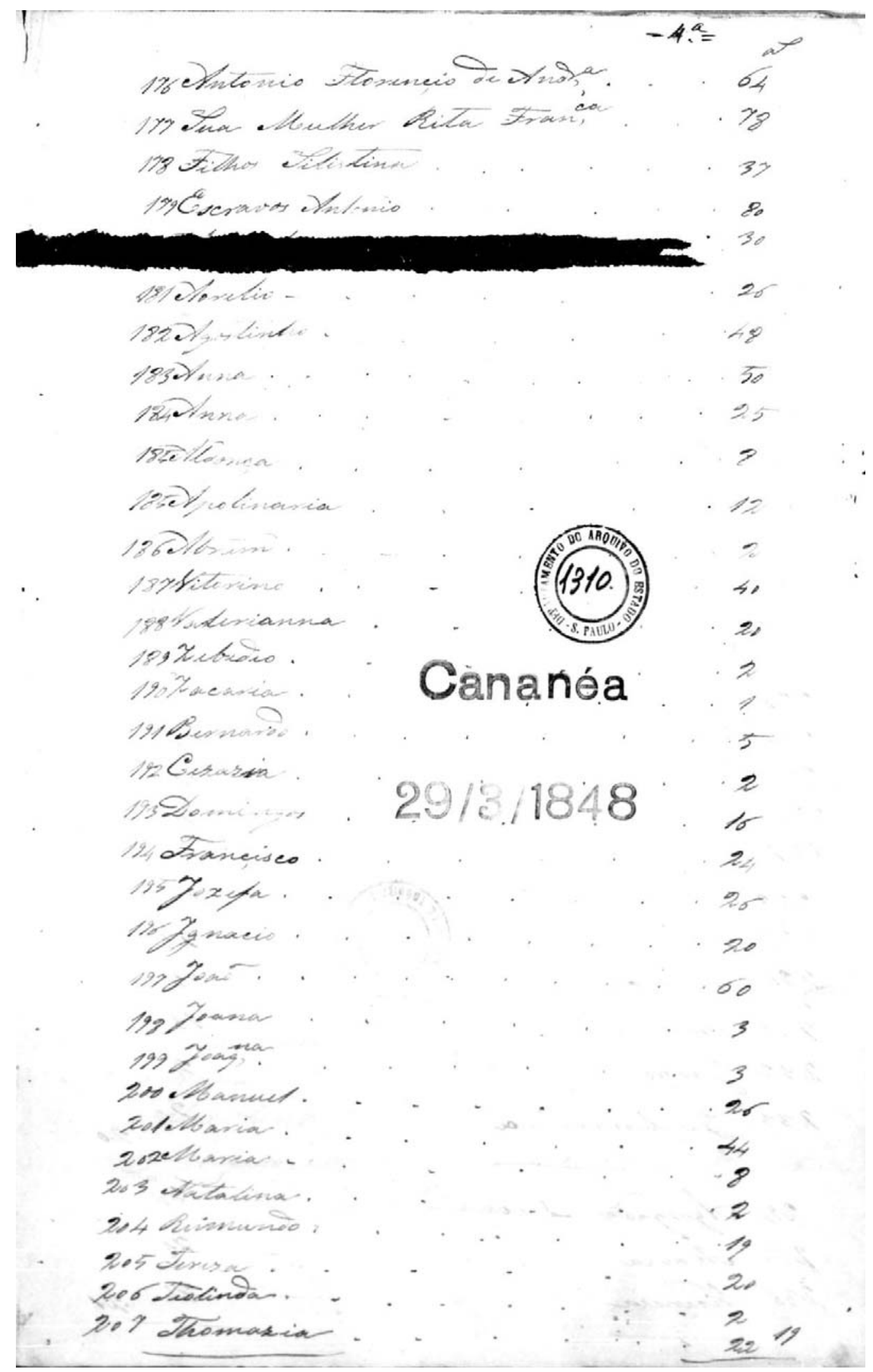




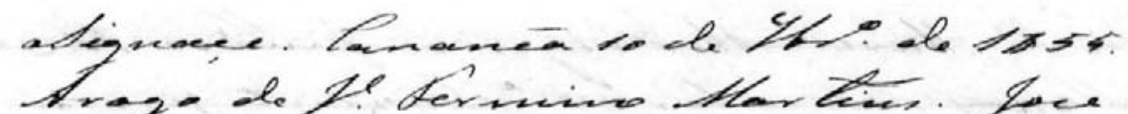

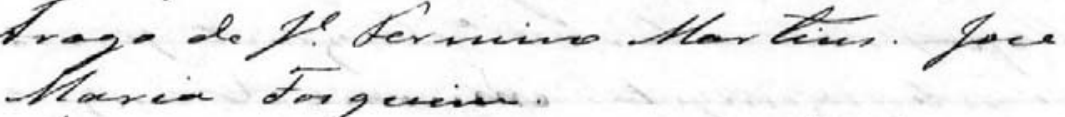

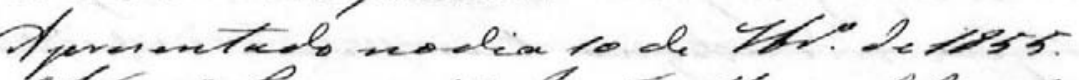

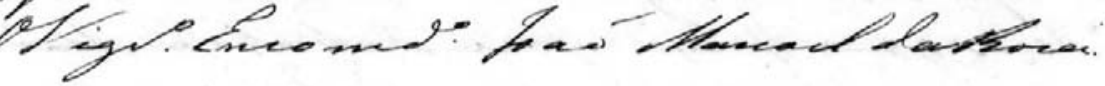

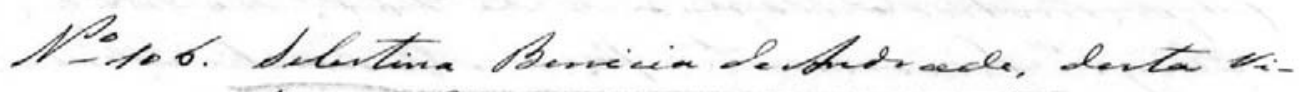

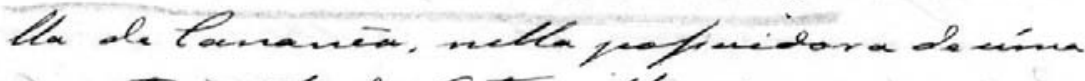

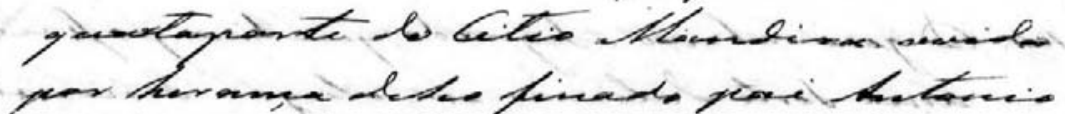

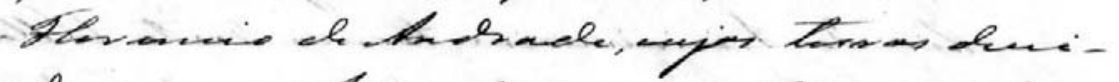

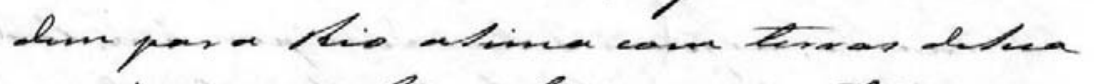

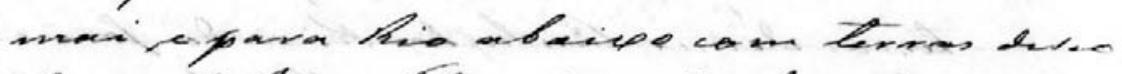

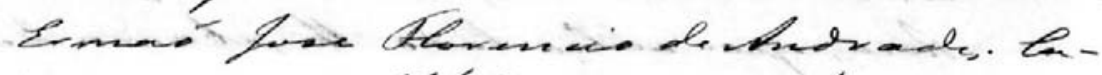

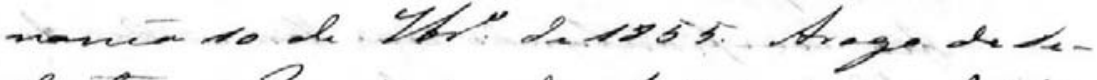

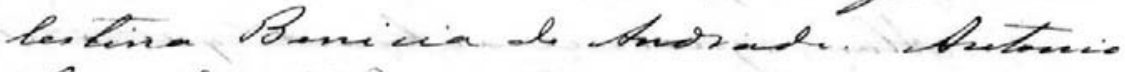

$$
\begin{aligned}
& \text { Ane of thereines. }
\end{aligned}
$$

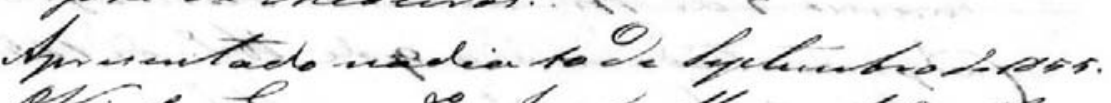

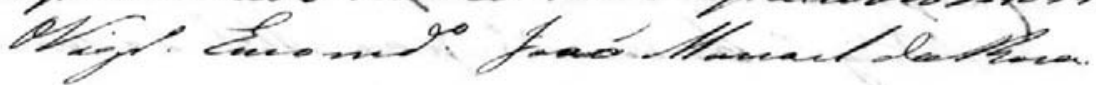

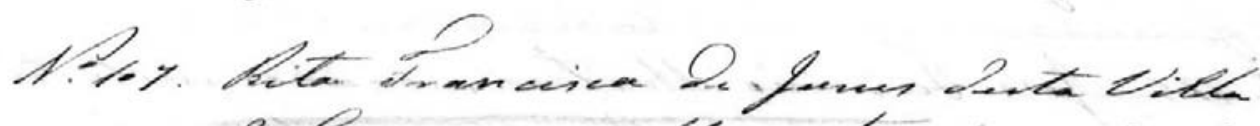

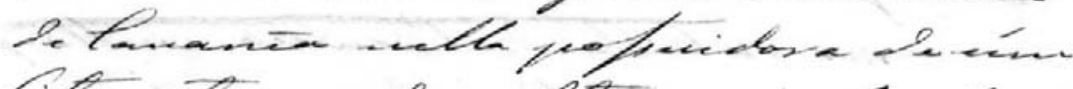

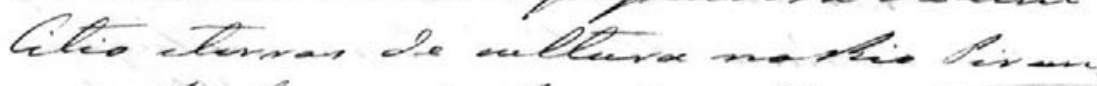

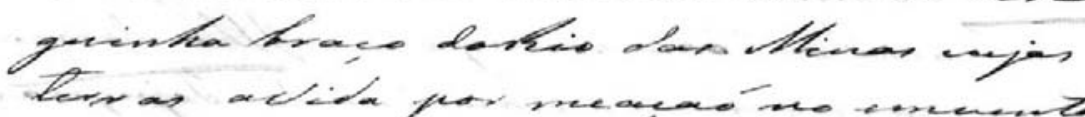

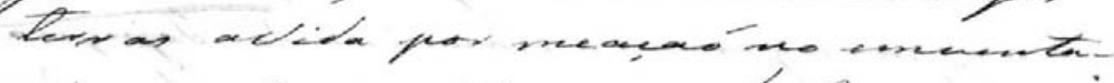

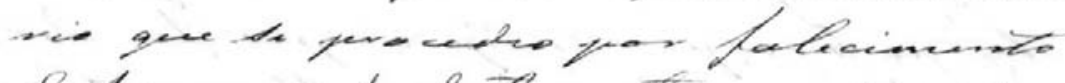

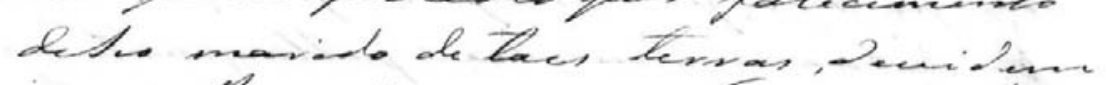

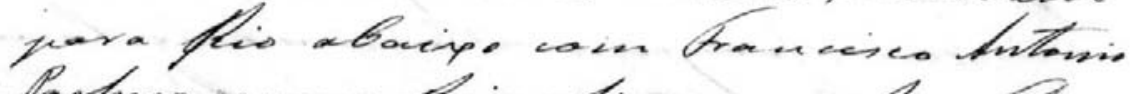

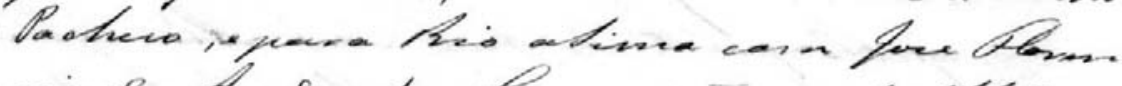

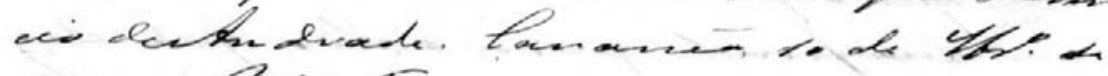

$$
\begin{aligned}
& \text { wor Rit of numica. }
\end{aligned}
$$

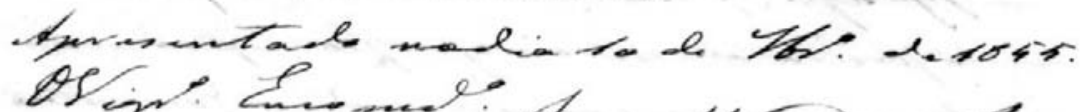

$$
\begin{aligned}
& \text { Os op L L...e? }
\end{aligned}
$$

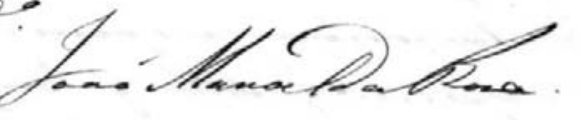




$$
\mathscr{P}=0
$$

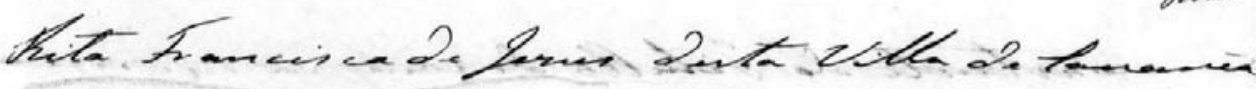

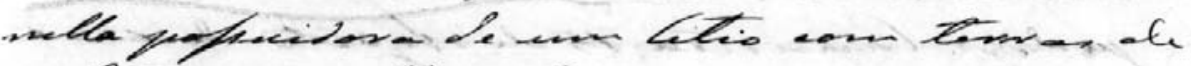

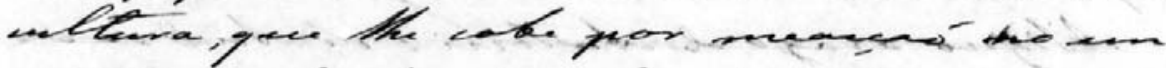

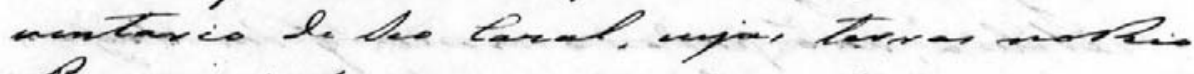

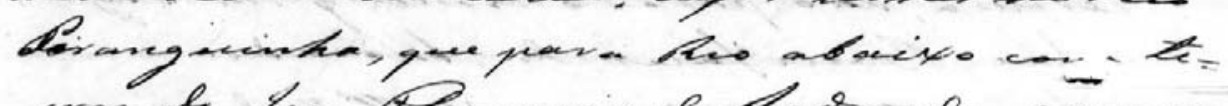

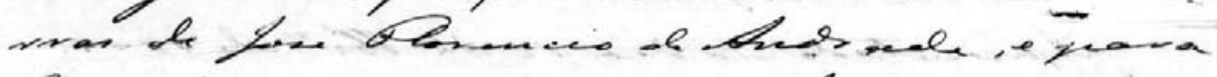

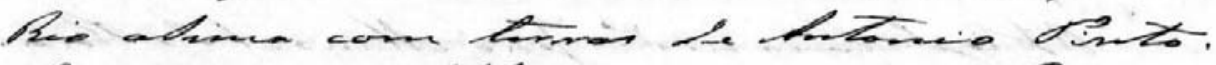

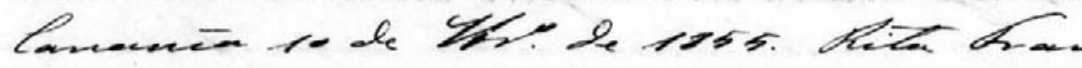

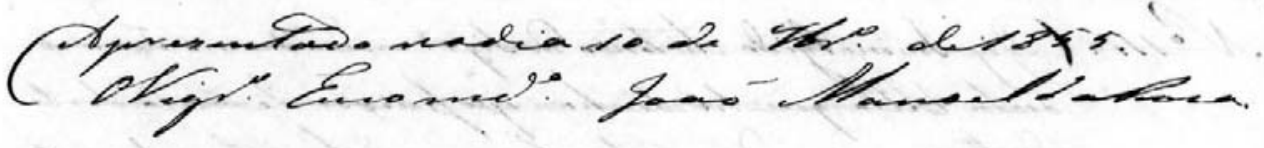

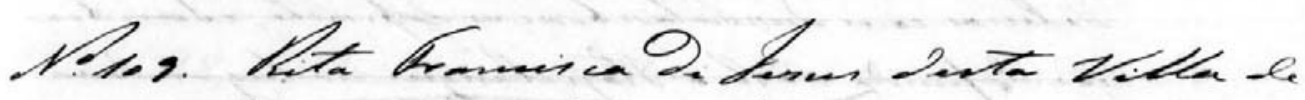

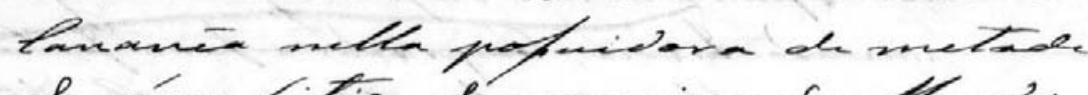

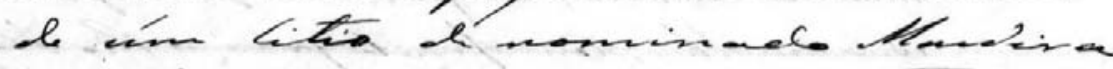

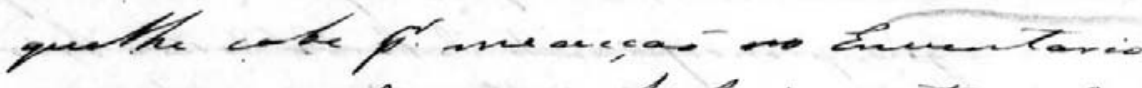

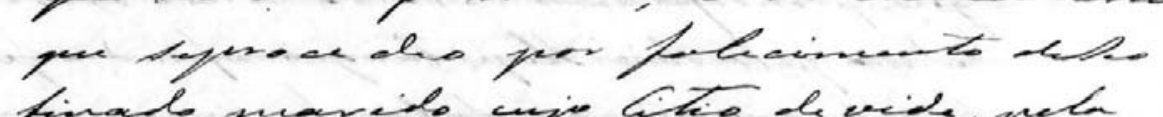

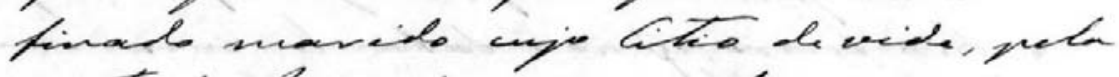
parte dothe atine cow teres de fow

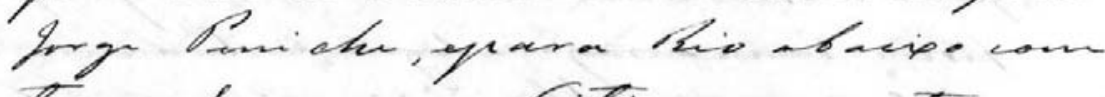

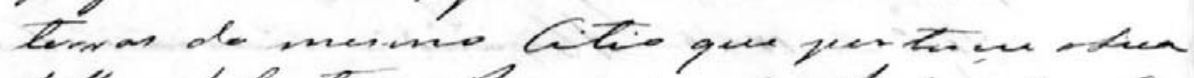

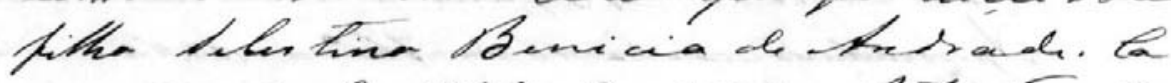

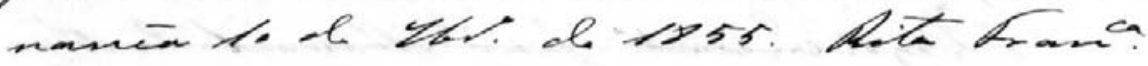

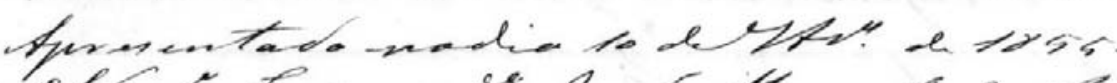

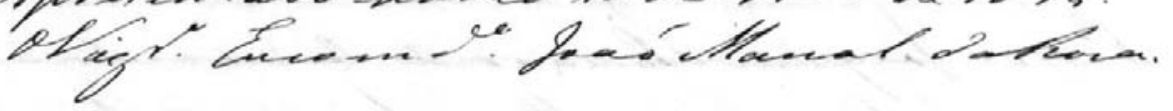

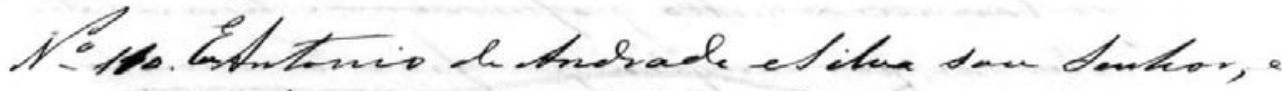

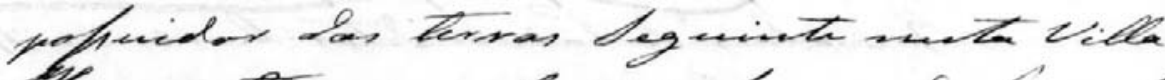

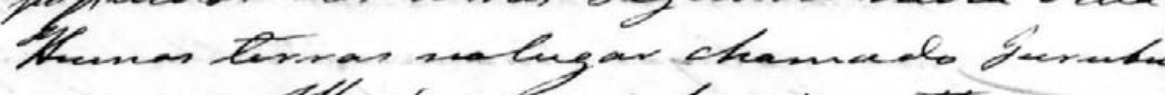

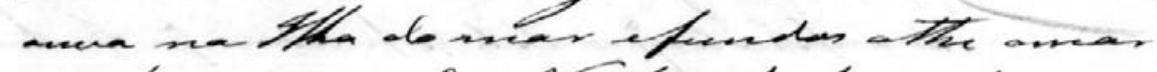

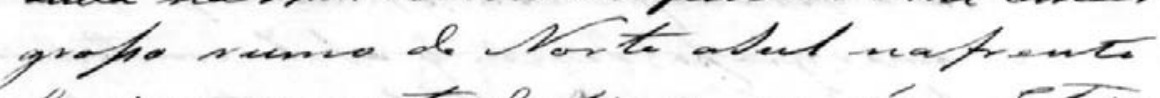

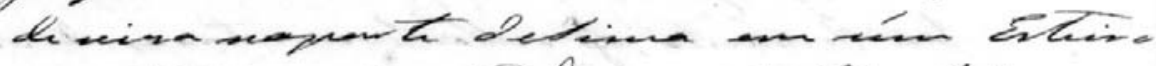

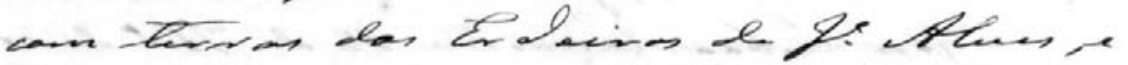

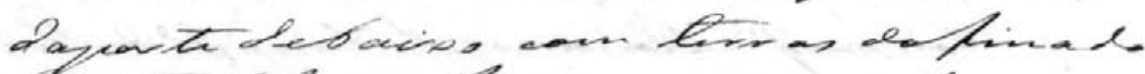

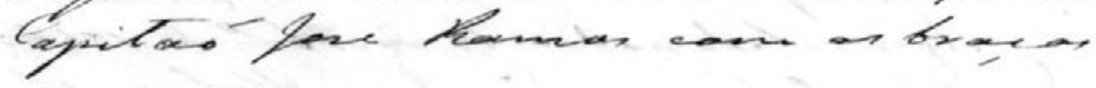


18038 these

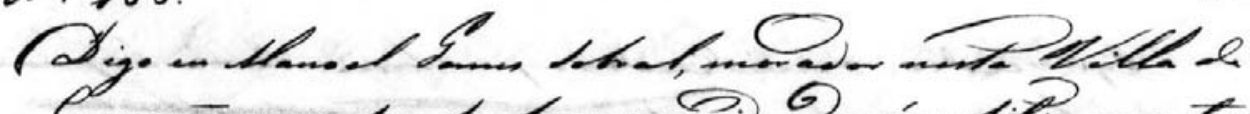

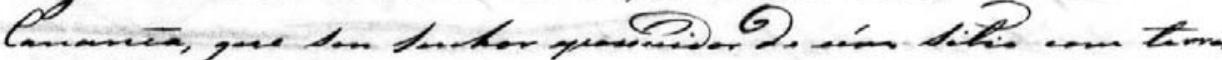

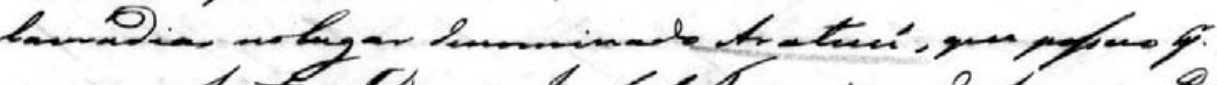

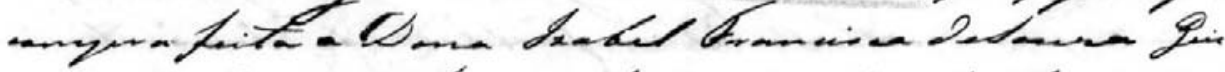

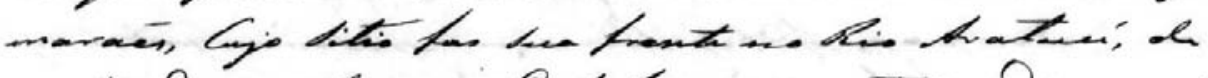

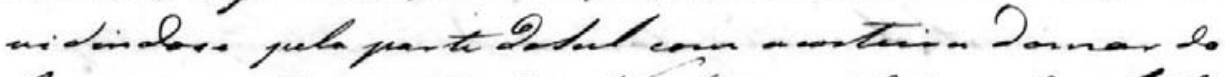

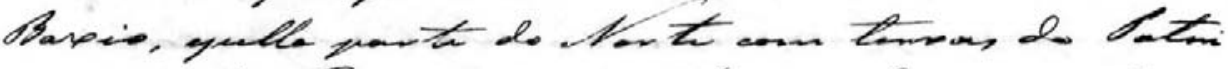

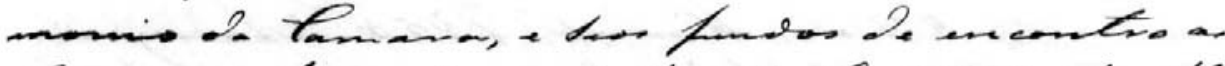

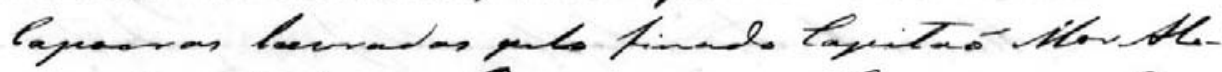

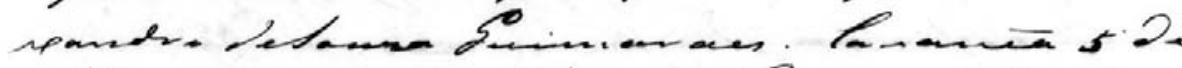

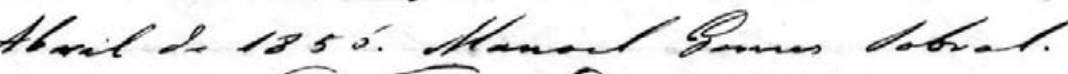

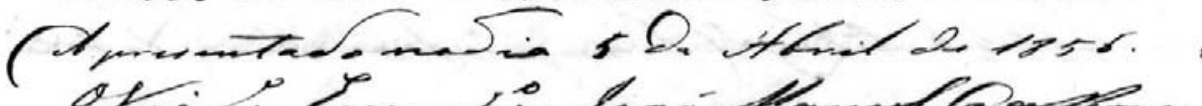

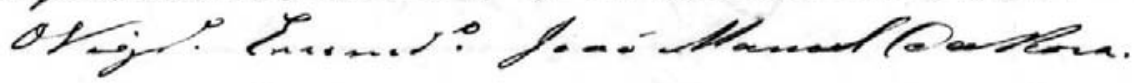

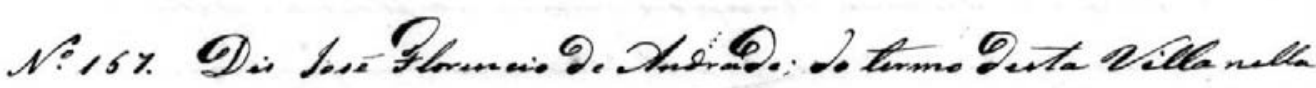

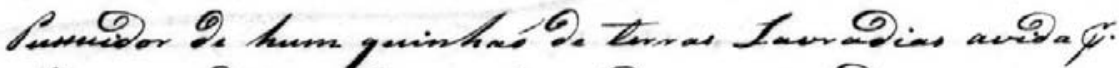

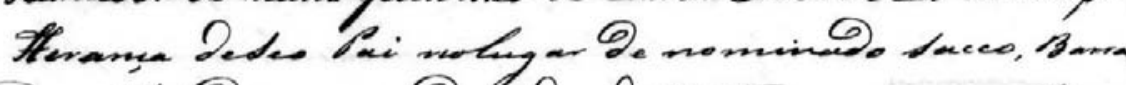

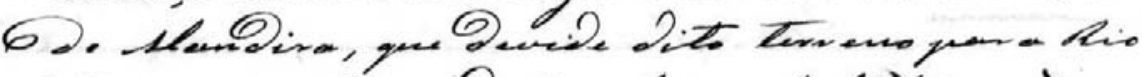

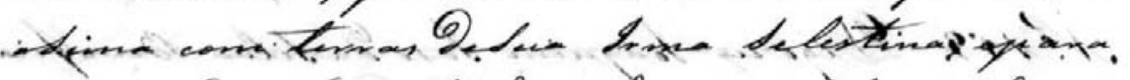

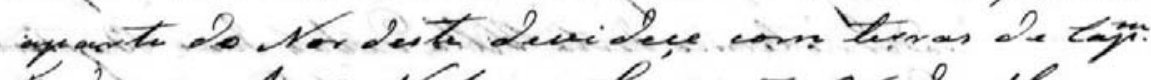

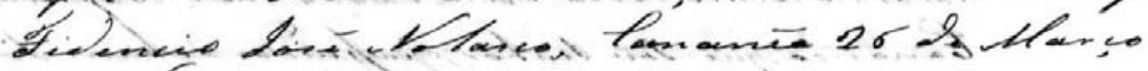
Q. 1556 .

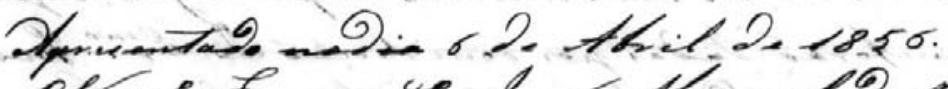

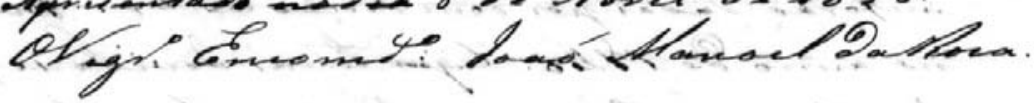

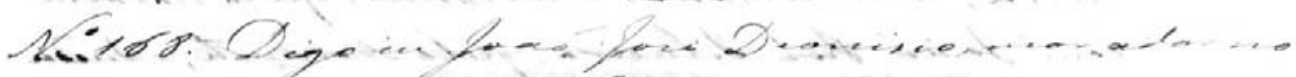

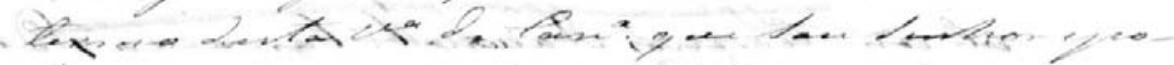

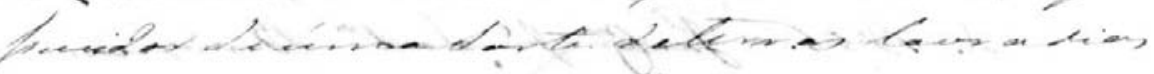

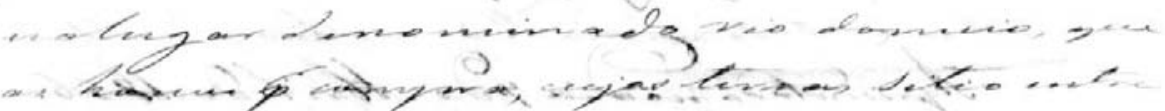

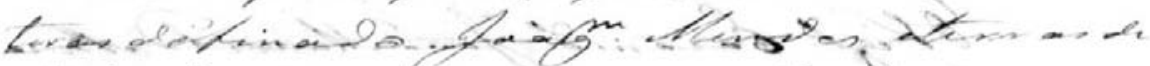

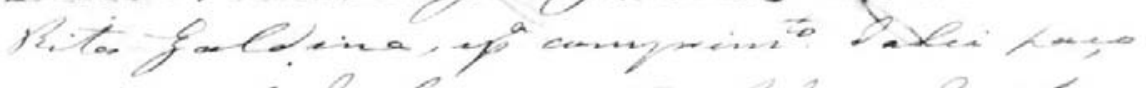

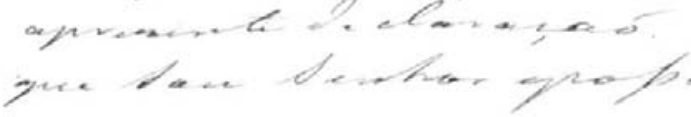




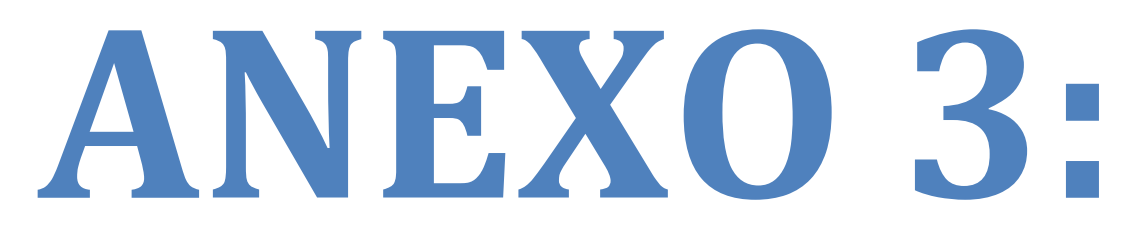

ENTREVISTAS 


\title{
TERMO DE CESSÃO GRATUITA DO USO DA IMAGEM E DEPOIMENTO
}

\author{
Venho por esta conceder o uso da imagem e \\ depoimento, concedido a Fabio Guaraldo Almeida, a fim \\ de contribuir com suas pesquisás no território Mandira.
}

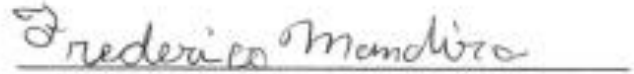

Frederico Mandira 


\section{Entrevista com Sr. Frederico}

PERGUNTA: Sr. Tava falando, Sr, Frederico, o Sr, Morava onde?

Sr. Frederico: Ah! Eu morava lá em baixo. Lá onde tinha casqueiro de sambaqui

PERGUNTA: Lá perto do Sambaqui:

Sr. Frederico: É! Eu morava lá

PERGUNTA: Sr. Morava lá

Sr. Frederico: Eu vim aqui pra cima.... A rapaziada vinha aqui, colocava aqueles tubos grandes, arvore grande.... e metia a enxada

PERGUNTA: A casa do Sr. Era ali mesmo perto do sambaqui?

Sr. Frederico: Era!

PERGUNTA: em cima do sambaqui ou embaixo?

Sr. Frederico: pra baixo

PERGUNTA: Perto do Porto?

Sr. Frederico: Pra cá do porto um pouco

PERGUNTA: Vocês viviam lá Dna Maria?

Sr. Frederico: Não

PERGUNTA: Ah!Vocês não eram casados ainda?! Sr. Vivia lá com seu pai, então?

Sr. Frederico: é, meu pai, justamente. Pra cá do porto...

PERGUNTA: pra baixo do sambaqui ainda? Perto do Rio Mandira?

Sr. Frederico: Não! Ali Rio Mandira ficava longe, ainda!

PERGUNTA: então era mais perto da trilha do porto de fora?

Sr. Frederico: a trilha era assim e a gente morava assim.

PERGUNTA: do lado da trilha... e lá o Sr. Morava com seu pai. E como era o nome do seu pai?

Sr. Frederico: Geraldo Mandira

PERGUNTA: e sua mãe?

Sr. Frederico: Maria Izidia Mandira

PERGUNTA: esses também foram uns dos primeiros aqui no Mandira?

Sr. Frederico: ah foi uns dos primeiros sim!!

PERGUNTA: O Sr. Chegou a conhecer seu avô? 
Sr: Frederico: Não! Nem pra me lembrar assim muito longe, mas acho que não dou conta. Eu vi ele, né, mas eu era pequeno ainda naquele tempo

PERGUNTA: Em que ano o Sr. Nasceu? O Sr sabe?

Sr: Frederico: Ah eu sei...eu nasci em...é ....ah...

PERGUNTA: o Sr tá com quantos anos? Quantos anos o Sr. Fez mês passado?

Sr: Frederico: eu devia tá com 85,83 anos, por ai

PERGUNTA: 85 anos?

Sr: Frederico: brotinho ainda!?

PERGUNTA: 83 anos?

Sr. Maria: ele é do dia do Santo Antônio

PERGUNTA: Dia 13, né!? É o mesmo dia que meu avô. Eu acho que meu avô tem mais ou menos a sua idade. 83 anos

Sr: Frederico: então o rapaz é ativo, né. Eu fiz aniversário agora dia 13 de junho

PERGUNTA: Dia de Santo Antonio

Sr: Frederico: Dia de Santo Antonio Justamente. Agora nós “tamo” em julho, né...

PERGUNTA: então o Sr é do começo do século? 1930? 1928? Né?

Sr: Frederico: é...1930, né?!!?

PERGUNTA: e o pai do Sr. Deve ser do século passado ainda?

Sr: Frederico: ah! Esse com certeza, né!

PERGUNTA: mas o pai do Sr conheceu o primeiro fazendeiro aqui, não?

Sr. Frederico: olha rapaz eu não sei contar essas coisas para você, porque eu também não sei.

PERGUNTA: eles não conversavam isso?

Sr. Frederico: eles não conversavam dessas coisas comigo

PERGUNTA: mas eles ensinavam o sr a fazer tudo?

Sr. Frederico: ah sim! Essas coisas que exisitia..., ensinava a fazer o que ia acontecer PERGUNTA: quando o sr falou que foram lá derrubar o...? onde foi mesmo, que o Sr. falou?

Sr. Frederico: ah! O pau...." caialivante”

PERGUNTA: o campo velho, né

Sr. Frederico: é! o campo velho, ali ....aquele pau grande e fazia uma cova em redor, cavava!....corria com o enxadão e machado e arrancava no muque

PERGUNTA: com enxadão e machado?!

Sr. Frederico: com enxadão e machado, e nós...a gente corta um pau grosso, faz uma leva de pau e finca nele e levanta e vira. Mas dificil! Não é fácil, não

PERGUNTA: quantas pessoas precisavam?

Sr. Frederico: ah! precisava 5,6 pessoas 
PERGUNTA: isso árvore grande?

Sr. Frederico: arvore grande

PERGUNTA: qual árvore? Qual madeira?

Sr. Frederico: "caialivante,bugre. Bugre é um pouco de espinho, espinhudo. A gente derrubava ele e tirava aquele espinho com a foice. Naquele tempo era foice e machado mesmo que havia, né...então a gente....era tudo brincadeira, era molecada, né! A gente fazia aquilo para brincadeira mesmo e nós fizemo campo.

PERGUNTA: fazia aquele campo!

Sr. Frederico: Arrancava aqueles pau, puxava aquela terra. Agora é tudo coisa de máquina

PERGUNTA: Agora é tudo máquina. O trator vem e faz tudo

Sr. Frederico: é! Leva uma meia hora e faz tudo

PERGUNTA: mas o senhor demorava quanto tempo pra limpar?

Sr. Frederico: Ah rapaz, não marcava hora nem tempo.

PERGUNTA: nem se preocupava

Sr. Frederico: não se preocupava, não marcava mesmo, passava e não via nada. Não pensava o que ia acontecer pra frente o que ia precisar

PERGUNTA: o que senhor fazia com essa madeira que derrubava?

Sr. Frederico: nós queimava, jogava fora

PERGUNTA: usava pra casa ou não?

Sr. Frederico: não

PERGUNTA: a casa era feita como?

Sr. Frederico: era de madeira também, de pau, mas já tinha outra madeira né?! Porque já tinha outra Madeira mais forte

PERGUNTA: já era madeira certa?

Sr. Frederico: já tinha madeira certa, já. Tem muita madeira que eu conheço, mas agora ninguém conhece mais. Tinha madeira Ipê, canela, mandagabú....

PERGUNTA: mandacaru? Mandagabú? mandaguaiú?

Sra Maria: mandagaiú!

Sr. Frederico: mandagaiú! É que minha língua não pra falar

PERGUNTA: essas são as madeiras boas pra fazer casa?

Sr. Frederico: pra fazer casa. É que tem cerne. Essas madeiras antigas vocês corta o miolo fora parede é só cerne puro, usava aquele cerne para fazer esteio. Igual carne

PERGUNTA: agora, como o Sr. Cortava a madeira? Porque hoje em dia é motosserra?

Sr. Frederico: era com machado, mesmo?

PERGUNTA: ai cortava e ai? Alisava? com o machado mesmo?

Sr. Frederico: alisava com o machado mesmo. Linhava e lavrava com o machado mesmo. O machado era para tudo 
PERGUNTA: O machado era para tudo?

Sr. Frederico: O machado era bem afiado, bem amolado, com pedra boa, uma lima boa PERGUNTA: Amolava o machado como? na lima ou na pedra?

Sr. Frederico: Na lima, na pedra. Era mais na pedra mesmo. Nesses tempos a gente arranjava essa pedra que tinha na cachoeira, conhecia né, trazia pra cá e afiava o machado com ele.

PERGUNTA: e você sabia o nome da pedra o não?

Sr. Frederico: ah não!

PERGUNTA: só a pedra da cachoeira?

Sr. Frederico: ah nome assim não conhece, a gente não sabia não marcava não, não ligava

PERGUNTA: mas sabia com era a pedra?

Sr. Frederico: ah sim! Conhecia qual era boa

Sra Maria: aqui em casa tem uma, nas coisas dele

PERGUNTA: tem uma pedra aqui? Ah! É aquela pedra ali

Sra Maria: ali na porta

Sr. Frederico: Essa ai ainda não é muito boa, porque essa ai é muito macio demais, custa muito a pegar fio, gasta muito

PERGUNTA: demora! Tem aqui afiar bastante?

Sr. Frederico: se gasta muito, né! é bom quando a pedra tem bastante "groda", que a pessoa passa uma caneta nele e come ela, ele come o ferro mesmo, então em pouco hora você assenta o fio. Se amolar sem água ele não presta, tem por água, afiando e molhando.

PERGUNTA: molha a pedra mesmo?

Sr. Frederico: Poe água na pedra, e vai afiando e vai molhando ele.

PERGUNTA: e usava pedra também para alisar madeira? para trabalhar com a madeira? Ou não?

Sr. Frederico: não!

PERGUNTA: mais o machado mesmo?

Sr. Frederico: mais o machado e o "cepilio"

PERGUNTA: "cefilio"? O que é o "cefilio”?

Sr. Frederico: hahahaha. Cefilio é um..... se não conhece não...agora tem a coisa de máquina, assenta a porta assim ( faz gestos com a mão para explicar), se alisa né ( faz gestos com a mão para explicar)

PERGUNTA: já usava o cefilio já?

Sr. Frederico: ah! Já se tinha bastante

PERGUNTA: e as casa era feita de madeira, então?!

Sr. Frederico: só de pau! 
PERGUNTA: e não era de barro também?

Sr. Frederico: não, mas de barro você faria depois só pra concluir.

Sra. Maria: Pra barrear!

Sr. Frederico: é pra barrear, tampar.

PERGUNTA: fazia a parede de madeira e depois barreava de barro?

Sr. Frederico: é

PERGUNTA: pra deixar mais quente, mais quente mais fria.

Sr. Frederico: primeiro era só madeira mesmo

PERGUNTA: depois era barro. E o barro pegava onde?

Sra Maria: falando ao fundo...

PERGUNTA: Como é dna Maria? Tinha barro certo pra pegar?

Sra Maria: tinha certo, mas barro barrento não prestava. Barro da beira do barranco era bom.

PERGUNTA: barro da beira do barranco! Barro de perto do mangue não ?!

Sra Maria: ah barro de perto do mangue não

Sr. Frederico: ah não! Não cola, né

PERGUNTA: então tinha ser barro da beira do barranco. Mas tinha lugar certo para pegar ou qualquer lugar?

Sr. Frederico: Não!

Sra Maria: qualquer beira de morro nós pegava o barro

PERGUNTA: uma vez, não sei se foi o $\mathrm{Sr}$ ou se foi o Sr. Bernardo. Eu acho que foi o Sr. Bernardo, antes de falecer, eu conversei com ele, e ele me falou que o Sr Cristino gostava de pitar e que ele fazia os cachimbos dele de barro.

Sr. Frederico: Ah fazia!

PERGUNTA: o Sr também fumava?

Sr. Frederico: muito pouco!

PERGUNTA: o Sr Cristino gostava? Ele que fazia os cachimbos dele de barro?!!!

Sr. Frederico: fazia de barro

PERGUNTA: e pagava o barro aonde?

Sr. Frederico: diz pegava lá em baixo, eu não sei porque, eu sei o lugar sei só. Ele pegava no ali embaixo, no rio ali embaixo.

PERGUNTA: aonde que era? qual rio?

Sr. Frederico: aqui no Urubici ai pra baixo, aqui no rio do porto ai pra baixo. Tinha um lugarzinho ali para baixo

PERGUNTA: no Boacica?

Sr. Frederico: no Boacica, na cachoeirinha que desce, depois pra cá tem um barranco que tem uma bola de barro branco, assim no canto, assim. Ali que ele pegava 
PERGUNTA: barro branco?

Sr. Frederico: é, ele pegava ali

PERGUNTA: mas ele morava lá do outro lado

Sr. Frederico: morava lá....uma viagem assim, um serviço, não ligava. Tava acostumado mesmo.

PERGUNTA: ele vinha lá de baixo pra cá pra pegar o barro?

Sr. Frederico: ah vinha!

PERGUNTA: ele conhecia tudo então!

Sr. Frederico: ah Meu Senhor! É criado aqui mesmo. Tudo quanto era assim sabia

PERGUNTA: então ele pegava ali no Riacho do Boacica?

Sr. Frederico: no Boacica, onde tem o porto da canoa, lá em baixo tem uma beira de barranco, no lado direito de quem vai daqui pra baixo, lado direito. A pessoa tem um, uma...uma borda de barranco no fundo assim, que tinha o barro branco. Era ali que ele pegava.

PERGUNTA: onde passa o rio

Sr. Frederico: por cima do rio ali

PERGUNTA: eu vi, eu conheço ali. Descendo ali. E era costume fazerem coisa de barro? Cachimbo tudo bem né!? Ai tinha que queimar. Fazia o cachimbo de barro e queimava?

Sr. Frederico: queimava!

PERGUNTA: queimava pra ficar duro!

Sr. Frederico: pra ficar duro

PERGUNTA: e era costume fazerem outras coisas de barro?

Sr. Frederico: não, aqui não, ninguém fazia.

PERGUNTA: panela, essas coisas

Sr. Frederico: pra cá ninguém fazia

PERGUNTA: era mais comprava na cidade?

Sr. Frederico: é! Comprava na cidade! Mas aqui na fazia as coisas de barro. Só ele fazia pito

PERGUNTA: pito!

Sr. Frederico: fazia, queimava e ficava ali no pito, no cachimbo.

PERGUNTA: plantava o fumo? Ou comprava fumo?

Sr. Frederico: não! Ele comprava fumo!

PERGUNTA: não chegava a plantar o fumo?

Sr. Frederico: não, plantar não. Ninguém plantava pra cá

PERGUNTA: o que o povo plantava pra cá?

Sr. Frederico: não, pra cá o que a gente foi acostumado a plantar era o que era coisa de comer, comida 
PERGUNTA: mas que era o que?

Sr. Frederico: milho, arroz, feijão, cana

PERGUNTA: cana! Plantava muita cana?

Sr. Frederico: Plantava bastante, essas coisas assim, plantava pra se manter com eles. Nossa criação, quanto começamos a trabalhar, que nossos pais fazia, nos ensinou era fazer essas coisas assim.

PERGUNTA: o trabalho era a roça?

Sr. Frederico: só a roça mesmo

PERGUNTA: tinha outra coisa?

Sr. Frederico: não tinha

PERGUNTA: não tinha não

Sr. Frederico: tinha negócio de pescaria, mas era só pra se manter. Ai depois eu comecei a ficar com maior idade é que eu comecei a pescar para vender, mas primeiro era só pra se manter.

PERGUNTA: e as coisas que plantava aqui vendia na cidade?

Sr. Frederico: um pouco vendia um pouco a pessoa comia

PERGUNTA: um pouco comia um pouco o pessoal comia. Vendia mais o que?

Sr. Frederico: vendia o que tinha pra vender, era arroz, era feijão, era milho.

PERGUNTA: vendia tudo, então, fazia a roça e o que sobrava vendia?

Sr. Frederico: o que sobrava vendia, comia, já deixava pra semana aqui.

PERGUNTA: como é que levava essas coisas pra cidade

Sr. Frederico: era por canoa

PERGUNTA: por canoa mesmo

Sr. Frederico: carregava lá no porto de fora, que tinha, descia pra baixo e embarcava na canoa descia pra baixo

PERGUNTA: mas era canoa motor?

Sr. Frederico: ah às vezes era motor, às vezes era a remo mesmo

PERGUNTA: o pessoal fala que aqui tinha canoa a vela? É verdade?

Sr. Frederico: ah tinha! Lá fora tinha. Quando lá embaixo tinha, mas no rio não dava ela não.

PERGUNTA: no rio não

Sr. Frederico: só no mar

PERGUNTA: e comercializava aonde Sr. Frederico? Onde comercializava?

Sr. Frederico: em Cananéia

PERGUNTA: em Cananéia! Ai precisava ser a vela?

Sr. Frederico: precisava a vela, precisava o remo, mais era o remo, né.

PERGUNTA: mas ai ia de remo até Cananéia? 
Sr. Frederico: ah ia! Quantas vezes não fui

PERGUNTA: é mesmo!?

Sr. Frederico: Meu Senhor! Quantas vezes não fui a remo. Eu com meu sogro fomos a remo daqui lá, até o canal carregado de gente!

PERGUNTA: com o pai de Dona Maria? Como era o nome de seu pai Dona Maria?

Sra. Maria: Graciliano!

PERGUNTA: como? Graciliano?! E o nome da mãe da Senhora?

Sra. Maria: Martinha Mateus

PERGUNTA: Martinha Mateus! Ai ia o Sr e o Seu Graciliano?

Sr. Frederico: é

PERGUNTA: remando?

Sr. Frederico: ah era eu e ele remando, mas era como brincadeira.

PERGUNTA: mas enchia de coisa?

Sr. Frederico: Enchia! era com a canoa bem carregada de gente, de comida

PERGUNTA: de gente também!?

Sr. Frederico: ah é, punha gente, fazia sentar tudo na canoa ali

PERGUNTA: família toda?

Sr. Frederico: família toda! Grandes e pequenos

PERGUNTA: ia todo mundo pra cidade!

Sr. Frederico: ia pra cidade, mas era brincadeira, pois já conhecia bem o lugar.

PERGUNTA: mas dizem que a navegação ai no mar de dentro é difícil, não é?

Sr. Frederico: não é difícil não, porque não dá muito vento. O vento que dá é pouco. Dá vento mas não é... muito. Conforme a pessoa ia sair de casa, já conhecia quando ia dar vento, já conhecia via. Via ali vindo vento sul, o vento mais perigoso que tem pra cá é o vento sul, é o mais perigo que tem. Porque o norte bate muito forte, mas não faz mal nenhum. Agora o sul faz mais perigo

PERGUNTA: ai já sabia quando ia dar

Sr. Frederico: já sabia quando ia dar já tava chegando pra terra, chegando perto da coroa e era assim

PERGUNTA: O senhor chegou a ter barco a vela também?

Sr. Frederico: tinha! Mas a gente andava pouco, né!?

PERGUNTA: andava pouco porque não tinha necessidade?

Sr. Frederico: não tinha necessidade porque o vento dentro do rio para viajar ele quer a vela. A vela é para o mar largo, para cá a vela não dava...

PERGUNTA: e a vela era feita como?

Sr. Frederico: de pano!

PERGUNTA: de pano, mesmo! 
Sr. Frederico: algodãozinho

PERGUNTA: as mulheres que costuravam?

Sr. Frederico: as mulheres costuravam!

PERGUNTA: eram as mulheres que costuravam Dona Maria?

Dona Maria: é! Era!

PERGUNTA: A Senhora chegou a costurar?

Dona Maria: não! Não sabia fazer!

Sr. Frederico: Não sabia fazer a vela, mas sabia costurar.

Dona Maria: Sabia costurar sabia, mas cortar a vela, não sabia.

Sr. Frederico: Ah! A pra cortar a vela era difícil quem sabia de cortar

PERGUNTA: era difícil!? Não era todo mundo que sabia?

Dona Maria: A minha mãe cortava!

PERGUNTA: a mãe da senhora cortava? Dna Martinha! Ela cortava a vela! o pai da senhora tinha barco a vela?

Sra Maria: tinha!

PERGUNTA: Mas era comum barco a vela aqui?

Sr. Frederico: ah! Era! Canoa grande...aqui tinha bastante canoa grande, então servia pra dar vela nela

PERGUNTA: era a canoa grande era de um pau só?

Sr. Frederico: um pau só

PERGUNTA: e ai cortava a canoa?

Sr. Frederico: é! Fazia a canoa como fazemos num pau só, mas tem pau de fazer canoa de três, quatro palmo de largo, de boca.

PERGUNTA: canoa assim!!

Sr. Frederico: ah tem!Largura! Então a pessoa já sabia, a pregava a vela na canoa, quando ia para a cidade quando caia o vento daqui pra lá, que era o vento sudoeste, a pessoa punha a vela e ia. E quando nós ficava lá na cidade e era pra vim embora era, tinha que ser nordeste, o vento do mar, ai a pessoa vem!

PERGUNTA: ai tinha que tirar a vela?

Sr. Frederico: não! Mudava só

PERGUNTA: ah mudava o lado. E sabia direitinho pra onde tá vindo o vento?

Sr. Frederico: ah sabia! Oh se sabia!

PERGUNTA: falaram também que tinha vela com saco de arroz? É verdade isso?

Sr. Frederico: tinha! A pessoa...quando o vento bate na vela, que ele enche a vela mesmo ele tem força igual um motor mesmo, a coisa de um motorzinho

PERGUNTA: ai tinha que ser forte?

Sr. Frederico: é! Ai a pessoa ia embora, só se sentava e ia embora. 
PERGUNTA: ai o remo era só para controlar?

Sr. Frederico: o remo só para controlar, é

PERGUNTA: e ai levava tudo que produzia?

Sr. Frederico: tudo que produzia levava

PERGUNTA: de quanto em quanto tempo ia para cidade levar as coisas?

Sr. Frederico: ai era conforme a encomenda tinha. Porque de planta, a pessoa ia recolhendo e vendendo, né?! Aquele pouco que tava para fazer uma carga já levava. E daí a pessoa fazia cesto, fazia gamela, fazia remo, fazia essas coisas para levar.

PERGUNTA: ah! Já levava às vezes até a gamela pronta?

Sr. Frederico: ah já!

PERGUNTA: fazia tudo aqui?

Sr. Frederico: fazia tudo aqui no sítio!

PERGUNTA: tinha casa de farinha?

Sr. Frederico: tinha!

PERGUNTA: onde era a casa de farinha aqui?

Sr. Frederico: depois que eu me mudei para cá tinha uma ali em cima

PERGUNTA: ai o Sr. fez outra casa de farinha aqui em cima?

Sr. Frederico: é!

PERGUNTA: hoje não tem mais?

Sr. Frederico: não, hoje não tem mais!

PERGUNTA: mas o senhor tinha feito aqui?

Sr. Frederico: tinha!

PERGUNTA: e lá embaixo era aonde?

Sr. Frederico: tinha em casa mesmo da pessoa

PERGUNTA: cada um tinha na sua casa!?

Sr. Frederico: é! Cada um tinha em sua casa

PERGUNTA: todo mundo tinha casa de farinha ou era só alguns que tinham?

Sr. Frederico: todo mundo não tinha não

PERGUNTA: todo mundo não

Sr. Frederico: mas a maioria do pessoal tinha. Fazia a farinha dentro de casa mesmo

PERGUNTA: e daí um usava a do outro?

Sr. Frederico: ah! Usava!

PERGUNTA: o que não tinha usava do outro?

Sr. Frederico: ah! Usava sim!

PERGUNTA: o senhor tinha?

Sr. Frederico: tinha! 
PERGUNTA: o senhor sempre gostou de plantar?

Sr. Frederico: ah! Gostei de plantar bastante. Tive muita roça, pra gente trabalhar eu tinha mesmo.

PERGUNTA: e como era a escolha do lugar para fazer a roça?

Sr. Frederico: ah conforme o que você ia plantar, né. As vezes ia plantar uma semente e aquele lugar não prestava, tinha que mudar

PERGUNTA: Se gostava de plantar arroz tinha que ia pra um lugar mais....

Sr. Frederico: mais mole, mais molhado, né

PERGUNTA: mais molhado! Ai quando plantava cana?

Sr. Frederico: ia mais seco!

PERGUNTA: é mais seco cana?! dai plantar feijão, essas coisas

Sr. Frederico: é! Feijão, cana, essas coisas, daí num lugar só

PERGUNTA: num lugar só plantava

Sr. Frederico: grão

PERGUNTA: rama!

Sr. Frederico: tudo lugar só

PERGUNTA: daí o milho já um lugar mais seco?

Sr. Frederico: não, também da no mesmo lugar.

PERGUNTA: plantava onde queria? Não tinha distinção de lugar? Esse lugar é meu e aquele é seu?

Sr. Frederico: não, não, aqui nossa aqui não tinha. Plantava onde queria

PERGUNTA: e um ajudava o outro?

Sr. Frederico: ajudava!

PERGUNTA: ou a roça era de todo mundo?

Sr. Frederico: não! Cada um fazia para si

PERGUNTA: cada um fazia para si, mas se ajudava.

Sr. Frederico: ajudava, o pessoal fazia ajuntório

PERGUNTA: fazia o quê?

Sr. Frederico: ajuntório!

PERGUNTA: ajudório?! Ajutório?

Sra Maria: bastante gente!

PERGUNTA: ajutório era quando ajuntava todo mundo?

Sr. Frederico: ajuntava ai 10-12 pessoas

PERGUNTA: é a mesma coisa que multirão?

Sr. Frederico: é a mesma coisa que multirão só que é mais gente

PERGUNTA: ah! Multirão é ainda mais gente? 
Sr. Frederico: mais gente

PERGUNTA: ajutório é só...?

Sr. Frederico: ajutório é só 8-10 pessoas só

PERGUNTA: ixe! Multirão é o que? 20 pessoas?

Sr. Frederico: de 20 pra cima. Multirão a pessoa não paga com dinheiro, paga com o baile, né!

PERGUNTA: com o fandango!

Sr. Frederico: com o fandango!

PERGUNTA: tinha muito multirão aqui?

Sr. Frederico: ah tinha bastante!

PERGUNTA: é!

Sr. Frederico: tinha

PERGUNTA: tinha fandangueiro aqui também?

Sr. Frederico: fandangueiro era mesmo do lugar

PERGUNTA: tinha fandangueiro?

Sr. Frederico: tinha! Pra brincar tinha! Pra dançar, tocar viola tinha! Tinha bastante gente

(criança falando da viola)

PERGUNTA: você é fandangueiro também, é?

(criança falando da escola)

PERGUNTA: rapaz! Tá ocupado mesmo! (falando com a criança)... e tinha bastante gente, então, nessa época?

Sr. Frederico: ah! Tinha bastante gente

PERGUNTA: tinha muita gente! morava tudo lá perto da...

Sr. Frederico: da casa de pedra lá...

PERGUNTA: o senhor morava lá na casa de pedra com seu pai, ai quando o senhor casou foi pra onde?

Sr. Frederico: vim pra cá, para perto da estrada.

PERGUNTA: veio perto da estrada, mas ainda lá daquele lado?

Sr. Frederico: daquele lado de lá, justamente!

PERGUNTA: mas ainda perto da onde que vocês moravam? Ainda perto da casa de pedra?

Sr. Frederico: não! Eu morei ali em baixo perto da casa de Cristino, ai mudei pra cá PERGUNTA: pra cá, para esse lado de cá?

Sr. Frederico: é!

PERGUNTA: faz quanto tempo que vocês estão casados, Dna Maria?

Sra. Maria: 50 anos! 
PERGUNTA: 50 anos! Mas ai antes de sair de lá pra vim pra cá, vocês já estavam casados?

Sra. Maria: Já!

PERGUNTA: Já eram casados?

Sr. Frederico: Já Já

PERGUNTA: vocês chegaram a fazer casa lá?

Sr. Frederico: fizemos!

PERGUNTA: mas ai foi aonde? Foi lá perto do Seu Cristino, ou não?

Sr. Frederico: não

PERGUNTA: onde foi a casa de vocês?

Sra Maria: lá perto da grota funda tinha uma casa

PERGUNTA: Perto da grota funda! Ah! Vocês chegaram a morar ali no campo velho, então?

Sr. Frederico: Ah! Moremo bem pertinho do campo velho (Sra Maria falando ao fundo) PERGUNTA: mas pra cima da estrada ou pra baixo?

Sra. Maria: Pra cima!

PERGUNTA: Pra cima! Eu vou buscar a tapera de vocês lá. (Risos) Pra colocar lá na história. Tem buscar essas coisas pra colocar na história. Acho que tá marcado aqui, Sr. Frederico, perto do Graciliano que é pai da Senhora. Tá tudo marcado aqui. E Dona Antonia que é do outro lado do córregozinho ali.

Sr. Frederico: é morava ali PERGUNTA: no córrego do Pinico ali. Tá certo isso?

Sra. Maria: Tá certo, num tá bem certo, mas tá certo.

PERGUNTA: Dona Antonia morava aonde? Não era ali também perto, ou não?

Sra. Maria: Córrego do Pinico não

PERGUNTA: Não? Era morava onde?

Sra. Maria: Não era morava pra cá

PERGUNTA: Pra cá?

Sr. Frederico: do Rio Pinico?

PERGUNTA: perto da onde ela morava?

Sra. Maria: perto do Sambaqui!

PERGUNTA: Ah! Perto do sambaqui

Sra Maria falando ao fundo

PERGUNTA: mas o rio pinico não passava por ali?

Dna Maria: Não!

PERGUNTA: Ah não?!

Dna Maria: O rio pinico passava pra cá do Sambaqui 
PERGUNTA: Pra cá do Sambaqui....ahahahha sim, ela morava pra lá do sambaqui, mais pra cima

Dna Maria: Era morava perto do papai

PERGUNTA: de Graciliano! Então tá! Deixa eu arrumar aqui. Então como era o nome dessa região toda? Tinha nome?

Dna Maria: Não!

PERGUNTA: mas não tinha um nome tipo a Grota Funda?

Dna Maria: lá pra baixo não tinha

PERGUNTA: lá pra perto do sambaqui não tinha, então!

Dna Maria: Não tinha Não!

PERGUNTA: mas já falavam do sambaqui?

Sr. Frederico: ah já!

PERGUNTA: já sabia do sambaqui?

Sr. Frederico: já!

PERGUNTA: eu vou colocar aqui, então, a Dona Antonia perto do Sr. Graciliano ( criança ao fundo). E o povo morava perto mas tinha um pessoal que morava mais afastado? Cada um num canto? Meio que nem aqui hoje?

Sr. Frederico: é! Justamente! Que nem aqui é

PERGUNTA: e como era a roça Sr. Frederico? Sr. que plantava? Como era pra fazer a roça? Vocês desmatavam lugar?

Sr. Frederico: a gente ia fazer assim...limpava com a foice tudo e depois derrubava com machado

PERGUNTA: o que sobrava derrubava com machado?

Sr. Frederico: com machado, pau grosso assim (mostra com as mãos), jogava tudo no chão com machado, trabalhava oito/dez dia cortando ali. Porque era no braço, né. Eu trabalhava, tinha que vir em casa almoçar, descansar, pra depois voltar. Era serviço pesado!

PERGUNTA: eu imagino!

Sr. Frederico: ah é

PERGUNTA: e depois botava fogo?

Sr. Frederico: ah! Botava fogo! Queimava tudo! Ai a pessoa tinha que limpar por baixo pra fazer covinha, botar rama. Depois para plantar milho precisava plantar....mas dava trabalho, não era mole não

PERGUNTA: Ah! Eu imagino, tinha que juntar um monte de gente!

Sr. Frederico: Ah é!

PERGUNTA: mas ai desmatava e colocava fogo?

Sr. Frederico: colocava fogo, justamente!

PERGUNTA: ou colocava fogo antes? 
Sr. Frederico: não, depois que desmatava tudo. Porque senão não queima e também se não queimar daí não dá planta nenhuma

PERGUNTA: tem que queimar?

Sr. Frederico: tem que desmatar tudo e queimar. Ai dá planta, mas se não queimar num dá planta.

PERGUNTA: ai espera um pouco depois que queima?

Sr. Frederico: ai estando queimado já pode trabalhar nele

PERGUNTA: já pode trabalha!

Sr. Frederico: pode plantar o que quiser já!

PERGUNTA: ai fazer as covas, plantava...

Sr. Frederico: daí carpia, tudo negócio de mão, porque nesses tempos a gente não tinha essas coisas, não tinha ajuda de nada. Carpia com a mão, limpava tudo com a mão mesmo. E depois tinha que tratar mesmo, carpir, deixar limpo, senão não dava nada de semente.

PERGUNTA: Tinha que proteger dos bichos também?

Sr. Frederico: Ah tinha! Tem um bicho que come a folha da planta. A pessoa tinha benzer pra matar o bicho que come

PERGUNTA: mas bicho grande ou bicho pequeno?

Sr. Frederico: não! Bicho pequeninho

PERGUNTA: Bicho pequeninho

Sr. Frederico: mas dá bastante na folha da planta

PERGUNTA: ai a pessoa tem que ficar cuidando sempre

Sr. Frederico: é! Tem que cuidar senão come tudo

PERGUNTA: Mas vinha bicho grande também? Por exemplo, se você plantar milho e deixar lá

Sr. Frederico: ah vem!

PERGUNTA: vem cateto, num vem?

Sr. Frederico: vem cateto, vaca, veado, maritaca, ouriço, tudo come milho

PERGUNTA: come tudo que plantou?

Sr. Frederico: come!

PERGUNTA: como é protegia desses bichos a roça?

Sr. Frederico: ah a gente ia matar, fazia a ronda com cachorro, matava, ai afugentava um pouco, saia...agora passarinho não, passarinho voa

PERGUNTA: agora esses bichos grande aproveitava também pra caçar eles?

Sr. Frederico: ah! Pra caçar

PERGUNTA: se matava comia?

Sr. Frederico: ah pouco! (risos)

PERGUNTA: qual que era a caça aqui que vocês faziam? 
Sr. Frederico: era cateto, paca, coati

PERGUNTA: cateto, paca, coati. Tatu?

Sr. Frederico: Tatu não come milho

PERGUNTA: Ah! Tatu não come milho.mas caçava também?

Sr. Frederico: mas caçava

PERGUNTA: veado essas coisas?

Sr. Frederico: veado come milho, come. Então é isso! A pessoa fazia mundéu....mundéu não conhece né?

PERGUNTA: conheço! Aquele espaço assim, óh, com comida.

Sr. Frederico: é! Passarinho comia ele. Fazia no carrero né?! Ele era por aqui assim (mostra com a mão)

PERGUNTA: Fazia o mundéu com o que?

Sr. Frederico: com pau

PERGUNTA: com pólvora mesmo?

Sr. Frederico: pau grosso assim

PERGUNTA: ah com pau!

Sr. Frederico: é! A pessoa corta um pau grande e grosso que é pesado e depois vai fazer mundéu

PERGUNTA: mas o mundéu...coloca armadilha no mundéu?

Sr. Frederico: coloca, em baixo.

PERGUNTA: como é o mundéu que vocês faziam?

Sr. Frederico: O mundéu você corta o pau, põe aqui assim (mostra com as mãos), põe uma cerca pra lá é pra cá.

PERGUNTA: no carrero?

Sr. Frederico: no carrero dele, o carrero dele é esse aqui. Põe a cerca pra cá e pra cá (mostra com as mãos), e esse pau no meio, ai amarra um pau pra armar ele e finca um gancho lá e amarra uma vara pra firmar e daí essa armação, forma armação bem embaixo...bem embaixo do mundéu lá

PERGUNTA: bem rente a terra?

Sr. Frederico: bem rente a terra, quando ele vem entra porque tá aberta...o pau...ele passa bate naquele ganchinho de lama, cai em cima dele ali

PERGUNTA: mas ai o quê que cai em cima dele?

Sr. Frederico: é o pau!

PERGUNTA: um pau? Ai já pega na cabeça e já mata?

Sr. Frederico: é, pega nele direto e já mata

PERGUNTA: ai é com um pau grosso, então! ele passou já e puff

Sr. Frederico: é o pau tum em cima dele

PERGUNTA: hoje em dia já se faz mais com pólvora, né! e com chumbinho, né! 
Sr. Frederico: pois é justamente

PERGUNTA: antes era com o pau, que tipo de pau se fazia?

Sr. Frederico: qualquer pau serve!

PERGUNTA: ah! Mas tinha que ser pau duro, não era?

Sr. Frederico: pau bem pesado

PERGUNTA: pesado

Sr. Frederico: pau verde, qualquer pau é pesado.

PERGUNTA: fazia com pau verde!

Sr. Frederico: (nome de pau....????) é pau pesado. A madeira seca ai que fica leve PERGUNTA: agora o Mundéu não pega todo tipo de bicho, pega?

Sr. Frederico: não! Que anda pelo chão pega.

PERGUNTA: que anda pelo chão!

Sr. Frederico: porque paca vem pelo chão comer

PERGUNTA: paca pega também

Sr. Frederico: paca, pega tatu, pega coati

PERGUNTA: raposa pega?

Sr. Frederico: pega!

PERGUNTA: pega a maioria dos bichos então? Veado não pega?

Sr. Frederico: veado não tem altura pra ele. Ele é muito alto

PERGUNTA: que outro bicho tem grande, alto, que tem aqui? Veado?

Sr. Frederico: é só cateto mesmo e porco do mato que é alto

PERGUNTA: porco do mato é alto também?

Sr. Frederico: é!

PERGUNTA: mundéu não pega?

Sr. Frederico: ah difícil! Porque não tem altura para ele

PERGUNTA: cateto o mundéu não pega cateto?

Sr. Frederico: pega fizer um mundéu de acordo para pegar, pega. Na altura...

PERGUNTA: e a onça? Tem onça ai?

Sr. Frederico: (risos) tem alguma, mas não cai no mundéu

PERGUNTA: ela que pega o mundeú!

Sr. Frederico: ah é! Não cai no mundéu não

PERGUNTA: mas tem muita onça ai?

Sr. Frederico: não

PERGUNTA: tem história do povo que encontra onça?

Sr. Frederico: não, história não tem... 
PERGUNTA: porque não ficou vivo pra contar...risos

Sr. Frederico: é! No tempo do meu pai tinha onça mesmo, mas só que não contava história.

PERGUNTA: mas hoje em dia não tem mais onça, será?

Sr. Frederico: ah! Num tem!

PERGUNTA: olha! Num tem mais gato do mato, será?

Sr. Frederico: gato do mato tem! (Risos)

PERGUNTA: eu é que não quero ver esses bichos ai! Gato do mato, onça, esses bichos, tá louco!!!

Sr. Frederico: gato do mato tem! Mas onça mesmo não tem

PERGUNTA: e tinha tempo certo de caça aqui Sr. Frederico?

Sr. Frederico: ah sim! Tinha o tempo de caçar

PERGUNTA: tinha?! Por exemplo, tal época do ano pode caçar, mas tal época do ano não pode

Sr. Frederico: Não pode, justamente.

PERGUNTA: quando que era?

Sr. Frederico: é porque do mês de agosto em diante a caça não consegue criar já, né. Tempo quente tá criando.

PERGUNTA: então ai não caçava?

Sr. Frederico: não! Ai não caçava, porque o tempo esfria, que o tempo de caçar ele

PERGUNTA: quanto é o tempo de caçar?

Sr. Frederico: de maio em diante

PERGUNTA: de maio em diante?

Sr. Frederico: é! Abril, maio. Ai gente caçava, a caça tá criada e tá gordo, né

PERGUNTA: Foi o senhor que disse que caçava nos meses que não tem R? que é maio, junho, julho,....foi o senhor que disse ou foi o senhor Bernardo, será?

Sr. Frederico: é verdade, é do mês de abril em diante pode fazer armação para caçar qualquer caça. De abril em diante tudo engorda, tudo....pode matar, é bom de matar

PERGUNTA: ai é bom de comer!

Sr. Frederico: agora tempo quente assim tá criando

PERGUNTA: ai é difícil! É igual ostra, né?

Sr. Frederico: é a mesma coisa

PERGUNTA: tempo quente é que tá procriando e tempo frio tá engordando

Sr. Frederico: é justamente!

PERGUNTA: é igual a onça, né. Aqui tem que trabalhar no inverno, né. Ah! Outra coisa que eu ia perguntar para o senhor. O senhor lembra da carvoaria que tinha ali perto do campo? Sabe uma carvoaria que existia perto do campo de futebol, do atual campo? 
Sr. Frederico: hum!!!eu me lembro, mas não me lembro do lugar não PERGUNTA: num tá lembrado do lugar?

Sr. Frederico: eu ajudei a fazer aquele coiso de carvão ali, ajudei a tampar ele PERGUNTA: ah o sr ajudou?

Sr. Frederico: mas só que não liguei pra mais nada, não sei o quê que deu, se não deu nada

PERGUNTA: mas de quem que era aquela carvoaria?

Sr. Frederico: era de um homem de Minas

PERGUNTA: de Minas? E porque ele escolheu aqui?

Sr. Frederico: Porque ele se entendeu com o Cristino lá, e Cristino mandou fazer ali PERGUNTA: Ah! Foi um acordo dele com Cristino para fazer ali

Sr. Frederico: Agora eu ajudei a cortar lenha para tampar, mas ai ficou ai por conta de Cristino com os irmãos, acabou-se então.

PERGUNTA: A carvoaria era do Sr. Cristino, então?

Sr. Frederico: Ah é!

PERGUNTA: Era do Sr. Cristino com esse homem?!

Sr. Frederico: é!

PERGUNTA: era de vocês então?

Sr. Frederico: era do nosso terreno mesmo, né. Nesses tempos não tinha divisa

PERGUNTA: e ai vendia o carvão ou não?

Sr. Frederico: eu não sei o que ele fez dele

PERGUNTA: não sabe

Sr. Frederico: não sei o que ele fez dele não. Eu sei que ele vendeu

PERGUNTA: vendia para onde na época?

Sr. Frederico: ah! Ele vendia em Cananéia mesmo, pra cá num tinha saída. Nesses tempos não tinha estrada ainda aí.

PERGUNTA: e ficou quanto tempo isso ai?

Sr. Frederico: ah Rapaz! 4, 5 meses. Foi 6 meses, acho, que ele fez!

PERGUNTA: ah! Pouquinho tempo

Sr. Frederico: É! Não deu nada por que o homem não prestava, eu acho que de certo. Num sei também!

PERGUNTA: (Risos)

Sr. Frederico: é! Era um homem meio tapado

PERGUNTA: que veio de fora querer de acertar

Sr. Frederico: pois é, mas não deu nada.

PERGUNTA: mas ainda tá a estrutura ali 
Sr. Frederico: tá lá, né!

PERGUNTA: o ano o Sr, não lembra? Que ano foi, não né?

Sr. Frederico: ah num lembro! Na minha cabeça eu esqueço

PERGUNTA: A Sra. também não lembra Dona Maria?

Sra. Maria: num lembro!

(risos)

Sra. Maria: Eu lembro que fizeram, mas quanto tempo eu não sei.

Sr. Frederico: pois é

Sra. Maria: A gente morava lá pra baixo... Trabalhava para cá

PERGUNTA: ah vocês moravam lá pra baixo. Ah! Então foi isso antes de 60?

Sr. Frederico: Ah acho que foi!

PERGUNTA: o Sr devia ter uns 20 anos, ou não?

Sra. Maria: Ah tinha mais!

PERGUNTA: tinha mais! 30, será?

Sr. Frederico: é uns 35!!!

Sra. Maria: Já era casado já

PERGUNTA: Ah! Já era casado?! Vocês casaram quando?

Sr. Frederico: Casemo em... (Sra. Maria falando ao fundo)

PERGUNTA: 30 anos atrás?

Sr. Frederico: Casemo acho que em 60, né (Sra. Maria falando ao fundo)

Sra Maria: Tá fazendo 50 anos que estamos casados

Sr. Frederico: .... Cananéia

PERGUNTA: e casava na Igreja?

Sr. Frederico: Ah! Como queria né! Pra no sítio casava no civil

PERGUNTA: casava no civil!

Sra Maria: Nós casamos na Igreja

PERGUNTA: mas ia lá no cartório em Cananéia? Ou o Juiz vinha pra cá?

Sr. Frederico: em Cananéia!

PERGUNTA: e na Igreja era aqui?

Sr. Frederico: é

PERGUNTA: ai tinha toda a festa?!...

Sr. Frederico: é! O que podia fazer era para cá então

PERGUNTA: Tinha festa! Mas tinha esse negócio de vestido de noiva, também, Dna Maria?

Sra. Maria: Não 
PERGUNTA: Era mais vestida arrumada e casamento. Era mais a festa que o povo se preocupava?

Sra. Maria: É também não fazia festa

PERGUNTA: também não fazia festa?

Sra. Maria só casava e pronto!

PERGUNTA: Tinha que ter padre ou era alguém da comunidade que rezava?

Sra Maria: Não! O Padre que vinha de Cananéia

Sr. Frederico: De Guaraqueçaba....né

PERGUNTA: De Baraqueça...da onde?

Sr. Frederico: De Guaraqueçaba

PERGUNTA: De Guaraqueçaba, ele vinha!?

Sr. Frederico: Vinha por fora, de lá

PERGUNTA: Ah não vinha de Cananéia

Sr. Frederico: Não! Vinha de lá

PERGUNTA: mas por que o Padre de Cananéia não vinha nessa época?

Sr. Frederico: não vinha, era difícil. Aqui no Mandira custava a vim. Não vinha mesmo. Vinha de lá do Paraná que vinha fazer festa, casamento aqui para nós.

PERGUNTA: é mesmo? Quer dizer que Cananéia mesmo o Padre não vinha!

Sr. Frederico: Ah! Não vinha, não

PERGUNTA: Tinha que esperar o padre lá de Guaraqueçaba vir

Sr. Frederico: é! Vinha de lancha ainda

PERGUNTA: e ele que vinha rezar a missa

Sr. Frederico: é!

PERGUNTA: mas também não vinha com frequência, provavelmente?

Sr. Frederico: não! Difícil para ele vir por que era longe

PERGUNTA: ai quando ele vinha rezava, fazia tipo casamento de todo mundo junto?

Sr. Frederico: tudo que tinha para fazer fazia

PERGUNTA: vocês casaram junto com mais alguém?

Sr. Frederico: ah sim! Essas vez casou um poquinho ai. Uns 5 - 6 mais

PERGUNTA: é dna Maria!?

Sr. Frederico: é! Fui eu, Luiz, Compade Tuli, Adelmino, um par de gente assim

PERGUNTA: um par de gente, né. Já casava todo mundo junto?

Sr. Frederico: é juntava tudo e ia fazendo casamento

PERGUNTA: e tinha cemitério aqui também na época?

Sr. Frederico: cemitério não

PERGUNTA: não! Tudo para cidade? 
Sr. Frederico: tudo para cidade!

PERGUNTA: é mesmo?! Todo mundo que falecia ia para cidade?

Sr. Frederico: cidade é! Era de barco, era de canoa, é...

PERGUNTA: Mesmo o pai do Sr. foi para lá?

Sr. Frederico: quem?

PERGUNTA: o pai do Sr?

Sr. Frederico: ah foi o primeiro que foi para lá! (Risos)

PERGUNTA: mas o avô do Sr. foi também?

Sr. Frederico: Ah! Com certeza foi, aqui no Mandira não ficava ninguém.

PERGUNTA: num ficava aqui. Foi pra lá.

Sr. Frederico: Não, aqui não ficava ninguém

PERGUNTA: Tudo no cemitério, mas de Cananéia!

Sr. Frederico: é! De Cananéia!

PERGUNTA: ai ia de Canoa?

Sr. Frederico: só de Canoa mesmo

PERGUNTA: e tinha alguma cerimônia, ou não? Para levar a pessoa? O corpo? Ou ia só os filhos mesmo?

Sr. Frederico: não, ia só a pessoa que gostava daquela pessoa mesmo. Não era um cerimônia...ia por que nesse tempo aqui no Mandira quando morria uma pessoa assim, se ajuntava tudo o pessoal da vizinhança, para fazer acompanhamento, para ir rezar. Agora que não vai ninguém, mas primeiro quando morria gente a pessoa acompanhava. Tinha aterro, tinha tudo.

PERGUNTA: rezava o terço?

Sr Frederico: ah é

PERGUNTA: o terço cantado?

Sr Frederico: cantado é!

PERGUNTA: fazia o terço cantado quando alguém falecia aqui?

Sr Frederico: fazia, é então. Então tinha bastante gente acompanhando a pessoa que morria

PERGUNTA: Sr. Frederico, vou mudar de assunto um pouco, o sr conhece umas estruturas de madeira que estão no mangue, que estão deitadas assim?

Sr Frederico: ah conheço! Mas só que não posso ir lá! Mas conhecer conheço.

PERGUNTA: e o quê que é aquelas estruturas? O sr. sabe o que é aquilo?

Sr Frederico: quando eu conheci o lugar, o mangue lá, já tinha no chão

PERGUNTA: mas aquela madeira é do mangue?

Sr Frederico: com certeza não é....

(interrupção com sequência em outro arquivo) 
Sr. Frederico: do dilúvio, né. Deu o dilúvio, então, quando secou a maré, que baixou o rio. Assim, que acalmou o tempo, apareceu aquelas madeiras lá. Por aqui tinha um causo que depois que acabou-se o dilúvio, que secou, dizem que os antigos que morava naquela casa de pedra ali, onde tinha escravo, desceram para baixo de canoa e chegaram lá embaixo numa coisa que tem lá, não sei onde era. Lá embaixo, passando o rio, tava um toco atravessado que desceu com água e parou lá na curva e tava uma onça em cima, nesse tempo. Então, eles que desceram para baixo, no tempo dos escravos, e viram uma onça em cima do toco lá

PERGUNTA: Eles desceram fugindo do dilúvio, então?

Sr Frederico: foi, foi

PERGUNTA: começou a inundar coroa e eles desceram de barco?

Sr Frederico: de barco, foi justamente, é.

PERGUNTA: e ai viram esse toco ai com a onça?

Sr Frederico: toco com a onça e ficou isso ai até agora pouco tempo, rapaz, tinha o toco lá. Agora a água tampou tudo. Há muitos anos, né?! Ficou esses tocos lá e diziam o pau da onça, diziam assim o pau da onça, né.

PERGUNTA: ah! O pau da onça!

Sr Frederico: tinha na coroa, na lá. Até pouco tempo

PERGUNTA: mas tinha um só ou tinha vários?

Sr Frederico: não! Lá tinha um só! Mas para cima, virando o mangue, tem bastante, vários tocos.

PERGUNTA: mas lá na barra do Mandira? É na barra do Mandira esse, ou não?

Sr Frederico: é! Que tem, tem. Agora muitos anos, a água já tampou, o barro tampou, mas eu conheci.

PERGUNTA: Eu cheguei a ver um lá!

Sr Frederico: ah foi!?

PERGUNTA: mas tá todo enlameado!

Sr Frederico: (risos) pois é por causa do barro, né!? Da terra que a maré leva, cobre.

PERGUNTA: Mas a gente cortou e o pau é duro, viu.

Sr Frederico: Meu Senhor! Aquilo ali é de muitos anos, aquilo é cerne de canela, eu não sei se é canela ou é....porque tem a canela que faz cerne assim, tem aquela coisa....esqueci do nome. Tem o mandagaú que tem o cerne muito bom. Arariguá! São as coisas que tem o cerne para toda a vida. Nunca vai acabar.

PERGUNTA: e não tem bicho que come?

Sr Frederico: ah! Não tem! O bicho fura depois com o tempo....Cajarana, são madeiras que tem cerne. E o cerne para muitos anos de vida, já digo. Agora esses pau que tinha primeiro, diz que no caminho, que a água agora, mato. Diz que era mato quando a água passou e carregou tudo, então ficou só o toquinho.

PERGUNTA: Ficou só o toco no fundo?

Sr Frederico: é! 
PERGUNTA: e o povo que saiu foi para onde? O povo que saiu de barco?

Sr Frederico: ah! Iam para Cananéia

PERGUNTA: ah foi para Cananéia!

Sr Frederico: é

PERGUNTA: isso no tempo dos escravos?

Sr Frederico: isso no tempo dos escravos! Porque tinha que ser Cananéia mesmo, não tinha outro lugar.

PERGUNTA: não tinha outro lugar!?

Sr Frederico: não!

PERGUNTA: e o povo desceu o rio Mandira?

Sr Frederico: desceu o Mandira, toda vida, desde..... Tinha a ponte ali, descia, por ali

PERGUNTA: sabe ali o sambaqui?

Sr Frederico: sei

PERGUNTA: o sambaqui foi formado como também? Qual a história que o pessoal conta?

Sr Frederico: foi formado pelo dilúvio

PERGUNTA: pelo dilúvio, né!? Mas o mesmo dilúvio que levou as madeiras, será?!

Sr Frederico: o mesmo dilúvio que levou as madeiras. Porque aqui descia esse rio que tem aqui no Mandira, ele encontrava com o rio que vem do Piranga. O rio ali, né. Se encontrava água ali e fazia um redemoinho, ali

PERGUNTA: Ah entendi! Que era o rio Acaraú e dos Mandira?

Sr Frederico: é! Ali se encontrava a água. O rio do Piranga...

PERGUNTA: o rio do Ipiranga?

Sr Frederico:é...o rio dali....das Minas e dos Mandira, ali onde tem o sambaqui, ali se encontrava a águas, então, e fazia um redemoinho ali.

PERGUNTA: um redemoinho!

Sr Frederico: ali que ficou o sambaqui

PERGUNTA: agora o povo diz, que quando passou ali a trilha...quando eles foram abrir essa trilha do porto de fora...o Sr. tava nessa época?

Sr Frederico: eu tava quando foi aberta essa trilha, mas no dia não tava.

PERGUNTA: no dia que foi aberto o sr. não participou, mas morava aqui, né!?

Sr Frederico: morava já!

PERGUNTA: o povo falou que saiu até osso de gente lá quando abriu?

Sr Frederico: diz que saiu, mas é que tava cavando para fazer o carreador, mas eu nesse dia num tava. Eu trabalhei muito com o homem lá, tinha muito não, mas trabalhava uns dias com ele, que ele...mas...nesse dia não tava, só pessoa mais moço que tava. Mas ali tinha mesmo pessoa.

PERGUNTA: ali tinha gente enterrada? 
Sr Frederico: ah tinha!

PERGUNTA: mas isso da época do dilúvio?

Sr Frederico: da época do dilúvio, justamente

PERGUNTA: o dilúvio limpou tudo então

Sr Frederico: depois o dilúvio passou é que ficou aquela coisa ali. Ai que ficou o sambaqui, ai depois do dilúvio passou ai num deu mais nada.

PERGUNTA: que levou tudo para lá...ai depois disso que foram construir a casa em cima do sambaqui? A antiga casa?

Sr Frederico: ah, muito depois!

PERGUNTA: e a casa que construíram ali era de quem? Sabe a casa de pedra?

Sr Frederico: a casa de pedra não tinha dono. Quem morava ali era o pai do finado Cristino.

PERGUNTA: o pai do finado Cristino?!

Sr Frederico: é! E a casa de madeira foi quem fez, onde tinha aquele abacateiro, ali quem fez a casa foi o finado Cristino

PERGUNTA: foi o finado Cristino mesmo!?

Sr Frederico: ele que fez a casa de madeira

PERGUNTA: então o finado Cristino morava ali, então.

Sr Frederico: morava ali, justamente.

PERGUNTA: Ai depois que ele mudou para outro lugar?

Sr Frederico: depois que ele veio para cá para cima

PERGUNTA: eu vou até colocar aqui

Sr Frederico: é pode colocar, foi ele que morou ali, que fez uma casa de madeira ali. Era uma casa boa, bem feita, de madeira.

PERGUNTA: agora tinha uma casa de pedra ali também, não tinha?

Sr Frederico: pois então, a casa de pedra já tava feito

PERGUNTA: quando ele fez já tava feito a casa de pedra?

Sr Frederico: já já

PERGUNTA: o sr. chegou a ver essa casa de pedra de pé?

Sr Frederico: mas não tava mais coberta

PERGUNTA: não tava mais coberta

Sr Frederico: quando eu vi já estava descoberta já

PERGUNTA: mas ainda tinha toda parede? com janela e tudo?

Sr Frederico: tinha! Tinha!

PERGUNTA: era grande a casa? Como era?

Sr Frederico: era grande

PERGUNTA: era maior que a do engenho? 
Sr Frederico: não, acho que era mesmo a coisa.

PERGUNTA: era a mesma coisa do engenho?! E quem morava ali? Ou era engenho?

Sr Frederico: não, não. Quem morava ali não sei. Não sei contar

PERGUNTA: mas o sr. acha que morava alguém ali ou era engenho de arroz?

Sr Frederico: morava....era os escravo que morava ali, devia ser porque..., mas não tenho certeza, quando conheci a casa já estava descoberto e só as paredes só

PERGUNTA: mas era grande a casa?

Sr Frederico: era grande! Bem feita!

PERGUNTA: era bem feita!? Quadrada?

Sr Frederico: quadrada e feita de pedra, num era tijolo não, era pedra

PERGUNTA: tudo só pedra?

Sr Frederico: só pedra

PERGUNTA: mas era quadrado ou era retângulo, assim? Era de comprida ou era quadradona

Sr Frederico: era quadradona

PERGUNTA: quadradona

Sr Frederico: igual a armação de uma casa mesmo, quadrada

PERGUNTA: mas o sr não chegou a ver ninguém morar ali, né!?

Sr Frederico: não, eu não vi ninguém. Quem eu sei que morou ali foi o Cristino

PERGUNTA: mas ai foi em outra casa?

Sr Frederico: é! Outra casa que ele fez, dentro da casa velha

PERGUNTA: dentro da casa velha? Dentro da casa de pedra?

Sr Frederico: é

PERGUNTA: quer dizer que ele chegou a morar dentro da casa de pedra?

Sr Frederico: é, só que foi na casa que ele fez

PERGUNTA: ah! foi na casa que ele fez

Sr Frederico: de madeira

Sra. Maria: mas não foi nessa de cá

PERGUNTA: não nessa que tá?! Na outra, em cima do sambaqui?

Sr Frederico: é no sambaqui

PERGUNTA: mas tinha a parede de pedra e ele fez uma outra casa dentro?

Sr Frederico: fez, de madeira

PERGUNTA: calma ai, deixa eu entender: Já tinha a casa de pedra, a parede levantada, ele fez...

Sra. Maria: tinha só o muro!

PERGUNTA: só o muro! Ele foi e fez o telhado!? 
Sra. Maria: é! Mas não junto com o paredão que tinha

PERGUNTA: mas ele utilizou as paredes de pedra que já tinha para continuar fazendo a casa?!

Sra. Maria: Não!

Sr Frederico: Não!

PERGUNTA: foi próximo?

Sra. Maria: ele fez de madeira, mas não fez encostado, não.

PERGUNTA: perto! Ah tá! Pensei que ele tinha feito dentro da casa. Nessa casa de pedra ninguém morava?

Sr Frederico: Não! Que se conheceu, não!

PERGUNTA: e depois como que caiu a casa? Caiu com o tempo? Com a chuva?

Sr Frederico: não! A casa que ele deixou, e depois ele mudou, a casa caiu, a madeira caiu. E a casa de pedra, no tempo que ele fizera a estrada ali, fazia o caminho roçando e derrubando. Acabou-se tudo ali

PERGUNTA: A casa de pedra foi derrubada quando fizeram a estrada ali?

Sr Frederico: quando fizeram a estrada!

PERGUNTA: e pegaram as pedras e levaram para..?

Sr Frederico: foi para calçar a estrada mesmo

PERGUNTA: vocês moravam ainda lá embaixo?

Sr Frederico: lá embaixo, nós morávamos lá embaixo ainda.

PERGUNTA: que era a antiga estrada....? como é que era o nome da empresa, lá? Fosfasa?

Sr Frederico: era Fosfasa, exatamente!

PERGUNTA: nessa época que vocês ainda usavam o porto ali, não usavam?

Sr Frederico: bastante!

PERGUNTA: o porto de fora!

Sr Frederico: é!...não sei porque vou contar, isso é bobagem, mas ali na ponta da prata, ali...tem uma..., eu não se ainda tem agora porque faz tempo que não vou para lá não sei como é que tá..., tem um caixão, tinha feito um carreador, que eles fizeram o carreador no tempo dos escravos, né! e lavraram com dois paus, arrumaram um assim e outro assim (gesticula com as mãos) e passavam por cima com a carroça deles, e agora ficou no chão

PERGUNTA: na frente da praça?

Sr. Frederico: fonte da prata!

PERGUNTA: ah! Fonte da prata! Onde é a fonte da prata?

Sr. Frederico: ah! Ai embaixo, quem vai ali na casa de pedra fazendo o caminho, tem o primeiro....que passa a estrada

PERGUNTA: perto da escola? 
(Voz ao fundo) na casa da pedra mesmo, tem o bosque pra fosfasia, aquela primeira pinguinha ali, fazendo a curva ali embaixo

PERGUNTA: rua da Plata? Na ponte ou no caminhozinho?

Sr. Frederico: no caminho! Agora não sei como é tá porque Julio abriu estrada para lá PERGUNTA: mas é depois do sambaqui ainda?

Sr. Frederico: é para cá do sambaqui do sambaqui

(voz ao fundo): antes de chegar no sambaqui

PERGUNTA: ah! Antes de chegar no sambaqui! Ah! Na primeira pontezinha?

Sr. Frederico: é na primeira pontezinha que tem

(voz ao fundo): você saindo nessa estrada aqui, chegando para baixo do areial, se anda mais ou menos uns 300 metros ali, naquela reta, fazendo aquela curva

PERGUNTA: mas as duas madeiras que você está falando é na estradinha? Na trilha?

Sr. Frederico: é! Agora pode ter se acabado, porque a madeira, muito tempo, muito gasto

PERGUNTA: mas a trilha é para esquerda ou para direita?

Sr. Frederico: não, mas a trilha que vai embora, a mesma trilha!

PERGUNTA: ah! A mesmo trilha!

Sr. Frederico: e esse daí era para eles passarem com a carroça deles

PERGUNTA: na pinguela mesmo! Na ponte!

Sr. Frederico: é

PERGUNTA: e ali chama rua da plata?!

Sr. Frederico: fonte da prata

PERGUNTA: rio a plata, fonte da plata...ali morava muito gente, né!?

Sr. Frederico: ah! Morava tudo para cá...para lá...para baixo

PERGUNTA: tem muita história aqui no Mandira, não é Sr. Frederico?!

Sr. Frederico: é rapaz! Pessoa velha tem muita coisa para contar antigo

PERGUNTA: sem falar que a história é antiga, né!?

Sr. Frederico: ah é! Meu Deus do Céu! (rs) é antigo mesmo!

PERGUNTA: essas histórias tem que deixar ai preservado para o povo saber o que aconteceu

Sr. Frederico: ah agora é isso! Tem muita coisa e lugar que conheço, andei, mas não posso falar mais nada porque acabaram os lugares já. Derrubaram tudo! Não dá para explicar bem direito ali, não. Se eu tivesse bom da minha cabeça e da minha boca eu explicava certo!

PERGUNTA: o senhor tá bom! O sr tá falando um monte de coisa ainda. Tá lembrando um monte coisa ainda. O Sr. tá bom da cabeça e da boca!

Sr. Frederico: risos!!!

PERGUNTA: e eu fico aqui perguntando para o sr, perturbando! 
Sr. Frederico: não! Não perturba não! Isso é bom para a gente distrair, né?!

PERGUNTA: o que o sr. fazia mais? Quando o sr. morava lá para aqueles lados?

Sr. Frederico: o que eu fazia era só trabalhar em roça e plantar para lá e para cá, trabalhando e caçar, pescar! A gente passeava muito. Era difícil o sábado que não saia com minha mulher a passear.

PERGUNTA: e passeava para onde?

Sr. Frederico: ah, par o sítio aqui!

PERGUNTA: para o sítio!

Sr. Frederico: para os outros lugares, para as casas, a gente ia

PERGUNTA: ia visitar os parentes?

Sr. Frederico: os parentes, é!

PERGUNTA: mas ia para as outras comunidades, também? Rio das Minas?

Sr. Frederico: a gente ia perto, mesmo

PERGUNTA: e a pesca? Como era a pesca aqui, sr. Frederico?

Sr. Frederico: A pesca....eu nunca pesquei com canoa a motor, eu só pescava com canoa a remo, mesmo. A pescaria era só para comer mesmo!

PERGUNTA: mas como era? Era na rede? Na vara?

Sr. Frederico: Na rede!

PERGUNTA: vocês que faziam a rede?

Sr. Frederico: ah, primeiro nós fazia a rede e nós pescava com rede. Arrastava a rede no mangue, né, ficavam em terra, mas sempre tinha muito peixe. Tinha muito peixe, pessoa ia passando uma redezinha matava robalo, tainha. Meu Senhor! Era muito fácil de procurar comida! Agora é difícil porque agora tem muita gente. Tem muita gente que trabalha num rio só! Ostra! Tinha muita ostra! Tirava ostra a vontade, agora não

PERGUNTA: comia muita ostra?

Sr. Frederico: se comia! Comia assado, ensopado. Cozinhava a ostra! Assado mesmo no fogo. Meu Senhor!

PERGUNTA: mas ai quando ia pescar com rede tinha que chamar mais gente para ajudar ou dava para pescar sozinho?

Sr. Frederico: as pessoas da casa mesmo, a família da gente. Os filhos da gente ajudava! PERGUNTA: vocês mesmo tiveram quantos filhos?

Sra. Maria: Nove!

PERGUNTA: Nove filhos! Tá tudo aqui no Mandira ainda, ou não!

Sra. Maria: Não! Um tá em Minas, uma mora lá no Porto, outro em Pindaúva, outro mora na cidade. Aqui tá só dois homens e três mulheres.

PERGUNTA: estão cinco aqui e quatro para fora. Mas tem bastante gente aqui ainda!

Sra. Maria: tem o mais velho....outro mora no Porto...(continua explicando ao fundo)

PERGUNTA: Pindaúva é aonde? 


\section{Sr. Frederico: Jacupiranga!}

Sra. Maria: Jacupiranga!

PERGUNTA: tem a trilha aqui que vai para Jacupiranga, né!

Sr. Frederico: é tem!

PERGUNTA: o pessoal usava essa trilha?

Sr. Frederico: usava! Eu usei muito!

PERGUNTA: o sr chegou a usar essa trilha?

Sra. Maria: eu só ia por ali para Jacupiranga

PERGUNTA: e tudo caminhando?

Sr. Frederico: caminhando, a cavalo

PERGUNTA: a cavalo!? Tinha cavalo aqui!

Sr. Frederico: tinha! Muito pouco mais tinha!

Sra. Maria: quem sabia andar a cavalo, tinha cavalo!

PERGUNTA: era bom, né!? burro tinha, também?

Sr. Frederico: muito pouco!

PERGUNTA: e o pessoal ia para Jacupiranga fazer o que? Vender coisa?

Sr. Frederico: não ia para lá fazer viagem mesmo

Sra. Maria falando ao fundo: ....ia passear

PERGUNTA: ah! Ia para passear mesmo. E quanto tempo demora daqui até Jacupiranga? Pela estrada?

Sr. Frederico: a pé?!

Sra. Maria falando ao fundo: eu não sei, eu nunca fui

PERGUNTA: A senhora mesmo nunca foi? Sr. Frederico que foi bastante?

Sr. Frederico: eu fui, mas só que daqui Jacupiranga é mais de um dia de viagem

PERGUNTA: mais de um dia de viagem!

Sr. Frederico: ah, para ira a pé é!

PERGUNTA: ai tinha que dormir lá e voltar no dia seguinte?

Sr. Frederico: ah é!

PERGUNTA: eu to querendo fazer essa trilha! Eu combinei com os meninos, acho que vai eu, o filho do seu Chico.... B Bill, ....

Sr. Frederico: ah vai!

Sra. Maria: agora é fácil! Porque a chapada do morro para lá não é mais mato

PERGUNTA: não é mais mato? Antigamente era só mato?

Sr. Frederico: só mato virgem!

PERGUNTA: e essas estradas? Esses carreadores? Quem foi que abriu eles primeiro? 
Sr. Frederico: isso foi no tempo bem mais velho, de nossos avôs, nem do nosso papai acho que não. Já tava aberto! Quem morou ali no Salto que abriu de certo, foi o irmão de Vovô

PERGUNTA: ah é!? Ele morava lá para cima!

Sr. Frederico: morava!

PERGUNTA: o seu tio avô morava lá, então?!

Sr. Frederico: é! Irmão de meu avô, morava no Salto! Com certeza ele que abriu, porque outro não podia ser, ninguém morava para lá.

PERGUNTA: essa trilha passa no Salto Mandira?

Sr. Frederico: ah passa! Cada lugar que você chega que tem gente velha, tem um que tem história para contar e não é só aqui, não

PERGUNTA: tinha gado aqui também, Sr. Frederico?

Sr. Frederico: não!

PERGUNTA: pasto, essas coisas não era de ter?

Sr. Frederico: não tinha não, para pastagem não tinha não! Para cá nunca teve.

PERGUNTA: comia mesmo era peixe e o que plantava?!

Sr. Frederico: era peixe, era carne

PERGUNTA: carne de caça?

Sr. Frederico: era, carne de caça!

PERGUNTA: e era muito?

Sr. Frederico: era! Tinha com fartura! Naqueles tempo o pessoal fazia fogo a lenha, o pessoal matava a caça e punha para defumar ele, e defumava e comia, ia comendo ali a carne, o peixe, a caça...

PERGUNTA: A Igreja, antigamente, antes de vocês virem para cá, quando vocês estavam para lá, aonde era a Igreja? Tinha Igreja aqui?

Sr. Frederico: Não tinha! Fazia o culto lá na escola.

PERGUNTA: mas a escola já tinha?

Sr. Frederico: a escola já

PERGUNTA: ou era...

Sr. Frederico: não! Era casa particular!

PERGUNTA: casa particular?

Sr. Frederico: Fazia o culto em casa particular, na casa do finado Jango.

PERGUNTA: do finado Jango, mas chamava casa particular?

Sr. Frederico: não, eu digo assim porque...

PERGUNTA: porque era do finado Jango, né

Sr. Frederico: é, do Jango, que fazia o culto lá

Sra. Maria: o Jango era o João Vicente, né 
PERGUNTA: João Vicente! Agora, lá era a casa dele?

Sr. Frederico: era!

PERGUNTA: o João Vicente era João Vicente Mandira?

Sr. Frederico: era!

PERGUNTA: ele morava ali perto da escola?

Sr. Frederico: perto da escola, atrás da escola

PERGUNTA: atrás da escola! Do que hoje é a escola, mas na época dele não tinha escola lá, ou tinha?

Sr. Frederico: não, não tinha escola ainda!

PERGUNTA: e tinha o que lá no lugar da escola!

Sr. Frederico: ah! Tinha só a casa dele só. Tinha um barracão que um tal de padre Diogo, trouxe um monte de criança, umas 100 crianças e fez um barracão de zinco lá, e ele morava pra lá, perto da casa dele.

PERGUNTA: Ah! O Sr João morava lá na mesma época que tinha esse casarão, lá e morava lá perto?

Sr. Frederico: é! Pertinho!

PERGUNTA: interessante! Era um casarão de zinco? Com criança?

Sr. Frederico: com criança! Tinha todo tipo de criança que ele tinha lá PERGUNTA: tinha muita é?!

Sr. Frederico: Meu Senhor! Tem o alicerce que ele fez, tem lá ainda.

PERGUNTA: o alicerce da casa tá lá?

Sr. Frederico: do barracão tá. Leonardo sabe onde é! Que mora ali

PERGUNTA: eu sei quem é. Eu vou lá hoje perguntar para ele.

Sr. Frederico: pode perguntar!

PERGUNTA: conversar com ele e ver se eu acho essa casa, esse barracão de zinco! Não é onde tá escola hoje?

Sr. Frederico: não! É mais para lá

PERGUNTA: e esse era muito antigo, né!?

Sr. Frederico: não! Esse não era muito antigo. È antigo, mas tá com uns sessenta anos, por ai.

PERGUNTA: mas foi antes de vocês virem para cá?

Sr. Frederico: antes de eu vir para cá

PERGUNTA: foi bem antes? Durou bastante tempo ou não?

Sr. Frederico: ah! Durou uns 2 anos mais ou menos

PERGUNTA: quanto?

Sr. Frederico: uns 2 anos mais ou menos!

PERGUNTA: 2 anos?! Então foi pouco! 
Sr. Frederico: não muito, não, né!

PERGUNTA: e nessa época ainda não tinha a carvoaria, né?!

Sr. Frederico: não!

PERGUNTA: a carvoaria veio depois?

Sr. Frederico: por isso que fez ali

PERGUNTA: por isso que finado Cristino mudou lá?

Sr. Frederico: pra cá, é

PERGUNTA: e depois que foram embora, o quê que o povo fez com o casarão de zinco?

Sr. Frederico: depois que foram embora é que fez a escola. Ai depois que eles foram embora, que acabou-se o casarão de zinco ai que fizeram a escola ali.

PERGUNTA: mas não usaram o casarão para fazer a escola?

Sr. Frederico: não!

PERGUNTA: o casarão derrubaram mesmo?

Sr. Frederico: ah é!

PERGUNTA: deixa eu perguntar um negócio para o senhor: tem a história né que o primeiro aqui era o Francisco Mandira, que recebeu as terras de doação?

Sr. Frederico: ah sim! Com certeza foi!

PERGUNTA: da Celestina, né?!

Sr. Frederico: é! Justamente!

PERGUNTA: dizem que o pai do sr. Francisco era o senhor aqui da terra com a escrava? Como é essa história que contam?

Sr. Frederico: o pai do Francisco, devia ser...eu não sei como era nome

Sra. Maria: Ah! Isso ele não se lembra!

PERGUNTA: O senhor da terra era o Antonio Florêncio de Andrade, que era o Senhor da terra. Agora o quê eu não sei era como era o nome da mãe do Sr. Francisco. Porque se o pai era o senhor da terra, era o Sr. Antonio Florêncio de Andrade, né!? agora a mãe, dizem que era um escrava dele.

Sr. Frederico: Ah!sim! mas isso ai também não sei dizer. Não sei.

Sra. Maria: vamos ver com o Chiquinho para descobrir então!

PERGUNTA: uns dizem que era Tereza outros dizem que era Francisca...

Sr. Frederico: pois é...

PERGUNTA: essa é uma dúvida que tenho ainda

Sr. Frederico: essa é uma, mas parece que era Augusta!

PERGUNTA: Augusta?

Sr. Frederico: então não é

PERGUNTA: o Sr. acha que era Augusta? 
Sr. Frederico: pois é, não sei como era o nome da mulher do João Mandira

PERGUNTA: eu tenho a relação dos escravos que o sr. Antonio Florêncio tinha na época que nasceu o sr. Francisco

Sr. Frederico: ah! Então deve tá marcado ai, então

PERGUNTA: eu vou ver aqui. Quando o senhor Francisco tinha 3 anos...

Sr. Frederico: Meu Senhor!!!

PERGUNTA: tinha uma Augustinha....

Sr. Frederico: isso ai não sei contar para o senhor

PERGUNTA: o senhor acha que era Augusta?

Sr. Frederico: Augusta era uma mãe desses ai, mas não sei de qual é, mas que tinha uma Augusta tinha!

PERGUNTA: é....Augusta mesmo não tinha

Sr. Frederico: então não tinha!

PERGUNTA: não, como mãe dele não tinha, mas pode ser que seja a mulher dele, depois?!

Sr. Frederico: sim! Eu acho que é, que tinha Augusta tinha, agora se era mulher...

PERGUNTA: essa eu ainda vou descobrir! Sr. Chico acha que chamava Francisca, e Dona Irene acha que chamava Tereza.

Sr. Frederico: risos

PERGUNTA: mas ai a gente descobre. E outra coisa, na época que venderam as terras lá, foi Amâncio que vendeu, não foi!?

Sr. Frederico: foi!

PERGUNTA: ele foi para onde? Depois que ele vendeu?

Sr. Frederico: Foi para Jacupiranga e Cajati

PERGUNTA: foi para?

Sr. Frederico: Cajati!

PERGUNTA: e lá ficou com a família toda e não voltou mais? Ou voltaram?

Sr. Frederico: não!

PERGUNTA: não voltaram mais! Ficaram lá! Ele não tá vivo hoje, né?

Sr. Frederico: não! Tá morto já!

PERGUNTA: mas a família dele tá lá ainda?

Sr. Frederico: um pouco tá, mas um pouco saiu de lá já, mas para cá não vieram.

PERGUNTA: quando vai cidade deixa de virar essa família como tá aqui hoje, junta assim?

Sr. Frederico: ah sim! É verdade! A filha dele mora tudo para lá

PERGUNTA: vocês tem contato com ela ainda?

Sr. Frederico: não! Não tenho 
PERGUNTA: a ultima coisa que eu queria te perguntar, Sr. Frederico

Sr. Frederico: risos

PERGUNTA: quando fazia a canoa, o senhor disse que usava o machado né?!

Sr. Frederico: só machado mesmo!

PERGUNTA: o machado, mas para cortar a madeira, e depois para moldar ela dentro?

Sr. Frederico: ai era o machado e o enxó.

PERGUNTA: e o enxó era feito como?

Sr. Frederico: é um....cavocada assim....uma enxada...mas é tipo de uma enxada, só que era estreitinho, assim. Às vezes entrava dentro e fazia com a enxó

PERGUNTA: mas o enxó era de metal?

Sr. Frederico: era de ferro mesmo! Tinha a enxó chata, que fazia por cima e enxó com goiva que fazia por dentro, tinha duas enxó. Alias, tinha 3 enxó, uma do cabo comprido, grande assim, que fazia por cima, a proa a polpa, e tinha a que fazia por dentro, uma pequena o cabo mais curto. E tinha o enxozinho do cabo curtinho que fazia a bojo da canoa

PERGUNTA: que fazia o quê?

Sr. Frederico: o bojo! É o que cava por dentro para assentar e virar, senta dentro e cavoca por dentro...e não fica penso

PERGUNTA: então tinha um que fazia em cima, o outro mais gordinho que fazia por dentro e outro de cabo fino que fazia o bojo!?

Sr. Frederico: ééé...

PERGUNTA: só queria agradecer o senhor!!!Muito obrigada!!!

Sr. Frederico: obrigada você também!!! Desculpe eu

PERGUNTA: desculpa eu incomodar o senhor

Sr. Frederico: não tem incomodo nenhum, quando quiser vim pode vim

Sra. Maria: foi bom que ele conversou um pouco...que ele fica aqui sozinho....

Sr. Frederico: foi bom!!! O que eu souber eu conto!

PERGUNTA: pode ter certeza que o senhor sabe muita coisa! Eu to aqui só para registrar!

Sr. Frederico: muita coisa não posso falar, mas o que eu me lembrar eu posso contar

PERGUNTA: se o povo todo desse mais atenção para o conhecimento dos mais velhos com certeza teria mais peixe, mais lugar para plantar...

Sr. Frederico: pois é, justamente.

PERGUNTA: mas muito obrigado mesmo!!!

Sr. Frederico: nada rapaz! Quando você quiser vim pode vim!

PERGUNTA: ah eu vou voltar sim. Mas posso tirar uma foto antes do senhor ir comer?

Sr. Frederico: tá bom! Por que eu falo muito coisa que não dá para conversar certo porque minha língua não dá mais, mas isso ai não é culpa minha. 


\title{
TERMO DE CESSÃO GRATUITA DO USO DA IMAGEM E DEPOIMENTO
}

\author{
Venho por esta conceder o uso da imagem e \\ depoimento, concedido a Fabio Guaraldo Almeida, a fim \\ de contribuir com suas pesquisas no território Mandira.
}

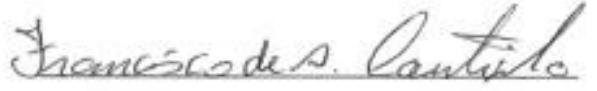

Francisco Mandira 


\section{Entrevista com Seu Chico}

PERGUNTA: Na história tem dois João. O João filho de Francisco era irmão ou primo do Antônio?

Irmão. João era irmão de Antônio.

PERGUNTA: E o Jango era filho ou neto do João Vicente Mandira, fillho de Francisco?

O Jango é filho de João. Ele tem o mesmo nome que o pai, João Vicente Mandira.

O Jango era irmão do meu avô e irmão do avô de Irene. Jango era o caçula.

PERGUNTA: Foi Jango que fez as rezas do terço cantado?

Não.

PERGUNTA: Quem foi que fez as rezas?

Ahhh isso já vem de muito anos atrás. O Jango já apreendeu com o pai dele e os irmãos mais velhos. Era meu avô que rezava o terço antes de Jango.

PERGUNTA: Qual o nome desse seu avô?

Francisco Vicente Mandira. O avô de Irene, Geraldo Vicente Mandira era o mais velho.

A música e letras do terço cantado vem de séculos passado. Ninguém sabe da onde que veio. Até por que antigamente não era só no Mandira que rezavam o terço. Taquari também rezava, aqui na Folha Larga rezavam o terço. Em Santa Maria rezavam o terço. Ariri, em todo lugar rezavam o canto.

DONA IRENE: Só que era diferente dos outros!

Não era tão diferente, não. Dependioa muito do Capelão, né? A única diferença aqui do João é que ele passou a ser espírita, né? Ai ele passou a ter uma responsabilidade a mais com o terço por que ele virou espírita.

PERGUNTA: E como foi o processo dele virar espírita?

Não sei direito. Pelo que eu sei ele começou a desenvolver com um cara de Cananéia. Um cara que era espírita e ele começou a desenvolver com ele. Um tal de João não sei o que lá...

PERGUNTA: Por que ele era bem sensitivo, né? O pessoal fala que ele previa as coisas, sabia quem ia visitar ele...

Não. O pai dele que fazia isso. O João velho. O velho sabia tudo que poderia estar acontecendo aqui na comunidade. Por exemplo, se alguém viesse fazer algum mal pra qualquer um ele já falava. Ou o bem também. Então, o finado João Vicente velho era vidente. Ele previa a coisa e era batata! Mas não chegou a ser espírita. O Jango era espírita. Ele curava, era um ótimo curandeiro, trabalhava só com erva e benzimento, mas não adivinhava nada.

PERGUNTA: Ele chegou a passar esse conhecimento pra alguém?

Tentou. Muita gente tentou desenvolver com ele. Até hoje tem uma mulher lá em Pindauva no Guaraú que ainda trabalha e desenvolveu com ele.

PERGUNTA: Não só o povo aqui do Mandira, mas o povo... 
Não. Muita gente de fora que dizia ter o dom de receber espírito vinha aqui pra desenvolver. E ele ajudava o pessoal a desenvolver. Mas esse pessoal dessa época tem só uma mulher lá do Guaraú. O resto já morreu tudo.

PERGUNTA: E como é a história do fazendeiro que perseguia o João?

O João velho você tá falando, né?

PERGUNTA: Isso, o João velho. Como é essa história?

Tinha o Cabral. O Coronel Cabral que dizia ser dono das terras do Mandira. Na verdade de milhões de alqueres de terra, desde Itapitangui até Guarequeçaba. Inclusive as do Mandira. E João brigou muito com ele. Por isso ele registrou as terras em 1912. E ai ele ganhou a questão. Ehhh tem uma história meio esquisita nessa briga que o finado Cristino contava pra nós: que o Coronel ganhou a questão, mas perdeu as terras.

PERGUNTA: Como assim?

(Risadas) Até agora eu não entendi essa história que o finado Cristino dizia que o Coronel ganhou a questão, mas o juiz deu as terras para o João.

PERGUNTA: Agora, Dona Saturnina diz que Antônio e João brigavam muito entre eles. Qual era a questão das brigas?

É eles brigavam. Mas é que eles eram irmãos, né? E a briga, pelo que eu sei, é que Antônio era muito ruim, né? Era péssimo. E João era um homem pacífico, né? E ele não gostava que ninguém pegasse nada dele. Canoa dele ele varava nas costas e deixava lá no meio do mato pra ninguém pegar. $\mathrm{O}$ remo dele ninguém pegava, apesar de ninguém aquentar remar. Diziam que era dessa grossura o cabo (mostrando uma esfera com os dois polegares juntos e os dois indicadores juntos). E só ele remava com ele mesmo. Mas a canoa dele, ele chegava de Cananéia e varava carregando nas costas e trazia cá pras Áreas, segundo o pessoal conta, né? Deixava lá pra ninguém usar. E quando o João fazia roça no salto, ele ia na roça e quando o milho estava bom pra cortar ele quebrava tudo e carregava. Canoa, ele quebrava a canoa de João no meio, carregava metade e deixava o outro pedaço lá, quando João ia varar a canoa tava só a metade da canoa.

Pra evitar as confusões ai que eles dividiram: Antônio ficava do morro da pedra pra lá e João do morro da pedra pra cá. Pra evitar confusão.

PERGUNTA: Engraçado ter o salto como divisor das terras, né?

É, mas a área herdada de 1.200 alqueires é a parte de cima e a parte de baixo. O João dividiu pra evitar as brigas, mas eles continuaram brigando até por causa do marco, por causa de divisa ali no morro das pedras. Por que ali pra cá da cachoeira tinha um Arapaçu... Isso eu vi ainda

PERGUNTA: O que é um Arapaçu?

É uma madeira. Tinha um Arapaçu que o pessoal jogava pedra e estrondava longe: Buuuummmmmm!!! Ali que eles diziam que era a divisa deles, do salto do João com Antônio.

PERGUNTA: Quem dizia?

O Antônio. Por que o João dizia que era no salto, onde é hoje, né?

PERGUNTA: Mais pra cima? 
Pra cima. O Arapaçu era mais pra baixo da entrada do salto, dali onde é a cachoeira. Sabe a pedra grande que entra pra cachoeira? Então, sobindo aquele morrinho de lá pra cá, era ali.

E assim ficou. Até o filho do Antônio tentou fazer uso-capião daquela área. Tentaram fazer muitas documentações em cima disso, mas nunca conseguiram registrar.

PERGUNTA: Quem era esse filho de Seu Antônio?

Miles Mandira. També era um homem péssimo também. Mas era menos que o Antônio. Que ele ficou sozinho lá, por que as irmãs saíram e o irmão morreu acho, e ele dependia mais do pessoal de cá, né?

PERGUNTA: Mas tinha um pessoal que morava lá. Por exemplo o pai do Evaristo morou lá em cima...

Não. O pai do Evaristo nasceu no Guaraú, em Pindaúva. Mas depois eles foram morar lá no salto. Moraram muito tempo lá. O Evaristo nasceu no salto.

PERGUNTA: A mãe do Evaristo era daqui então?

Não. A mãe do Evaristo também era de Pindaúva. Não eram Mandira, eram os Mateus. $\mathrm{Na}$ verdade eram tudo parentada, assim, a avó do Evaristo era irmã da avó de Irene. Mas eles não eram daqui, eram de Pindaúva.

PERGUNTA: Sempre existiu esse fluxo do pessoal ir pra lá e vir pra cá?

Teve. Toda a vida teve. O pessoal de lá vem morar pra cá, o pessoal daqui casa e vai morar pra lá. Toda vida foi assim.

PERGUNTA: Mas então eles moravam lá no salto. Plantavam faziam tudo lá em cima. Mas as terras lá eram menos usadas que as de aqui de baixo, né Seu Chico?

Não. É só por que lá tinha menos gente, né? Na época que eu era criança era o finado Miles, e a família do finado Joaquim, que era Vitorino, Tuca, Guilherme, uma cambada. E tinha uma época que eles viviam da extração do palmito. Eles trabalhavam muito com palmito. Mas é uma terra boa pra milho, feijão, mandioca.

PERGUNTA: E o pessoal costumava caçar lá em cima?

Caçar o pessoal caçava em todo lugar.

PERGUNTA: Mas o pessoal não fazia tapera pra ficar alguns dias caçando?

Não por que é perto. Eles iam e voltavam. Onde eles iam pra ficar semana era no Assungui. Açungui, Rio da Prata, Serra do Cadeado, tem vários nomes.

PERGUNTA: Onde é?

Dali do Rio das Minas entra pro meio do mato da umas duas três horas de caminhada. Lá eles passavam dias lá caçando. Meu pai, pai de Irene, Frederico, Adão Cunha, essa turmada. O pessoal do Pindauva vinha pra cá acampar pra caçar pra lá. Hoje tem grileiro de terra pra lá. Mas antigamente era ali que o pessoal ia caçar. Chegava a secar a caça e trazer tudo seco já.

PERGUNTA: E quando saia pra caçar caçava o que?

Tudo: paca, veado, porco do mato, cateto. Caçava muito porco-do-mato. Mas caçava muito. Até anta matava. Paca. No mês de maio iam caçar jacutinga.

PERGUNTA: Jacutinga é o que? 
Um pássaro. Tipo uma galinha.

PERGUNTAVA: E quem caçava, Seu Chico?

No meu tempo era meu pai, o pessoal do Pindaúva, Horácio...

PERGUNTA: Mas os mais velhos?

Era sempre os mais velhos, né? Mas casado, solteiro, quem gostasse de mato ia. A turma apreendia a caçar desde novo. Quando nascia algum menino, na casa, por que era tudo com parteira, quando era homem, o avô ou o pai da criança saia na rua e dava uns tiros com a espingarda na rua pra esse menino ser um bom caçador.

PERGUNTA: Então queria que ele fosse um bom caçador?

Queriam. Era o que eles gostavam. Como meu pai, Florindo, meu sogro, o pai de Irene, Frederico era também, mas eles eram bons no gatinho. Tinha que ser bom nbo gatinho. Caça correndo do cachorro no meio do mato, assim.... eles apontavam e TAHHLLL! Eles derrubavam.

Por que era pra comer. Então o cara tinha que ser bom, por que não podia errar a caça. Se errasse já... (meche a cabeça com desaprovação). Tinha essa coisa de ser bom caçador.

PERGUNTA: Tinha que ser bom, então? Mas como ensinava os moleques a caçar?

$\mathrm{Na}$ verdade o cara aprendia só vendo, né? Acompanhando. Como armadilha, também, apreendi vendo fazer. Era isso! Não tinha uma escola pra apreender a fazer. O cara apreendia no dia-a-dia. Vendo o mais velho a fazer ele fazia também.

PERGUNTA: Mas o bom caçador era quem sabia atirar?

Isso. Tinha que saber atirar. Aqui tinha um tio nosso que faleceu, ele tinha problema na vista, mas ele só atirava na cabeça dos passarinhos. Ele atirava para o bicho não correr, não ir embora machucado. Hoje o pessoal atira e o bicho sai lepe, lepe, lepe e vai embora. Antigamente não. O cara mirava a espingarda pro bicho e podia apostar que ele ficava ali. E aquela espingarda de carregar na boca ainda.

PERGUNTA: Existia uma certa consideração entre o grupo pelo caçador?

Não. No Mandira não tinha isso. Por que quando o cara caçava ele dividia com todo mundo.

Antigamente todo mundo tinha carne. Lá em casa mesmo, quando agente era criança, o fumeiro em cima do fogo vivia acesso com carne, peixe, era difícil faltar carne. Podia faltar farinha, feijão, alguma coisas assim, mas mistura, como peixe e carne era difícil. Em todas as casas era assim.

DONA IRENE: Difícil a casa que não tava secando um peixe, uma carne.

Todo mundo tinha peixe, tatu, quati, tinha muita caça.

PERGUNTA: A caça vinha na casa do povo, não vinha?

Vinha. Tamandua mesmo, vinha aqui perto de casa. Capivara também agente matou na casa de Vardo, no brejo o cachorro pegava também. As vezes nem cehgava muito perto da casa, o animal tava pastando, o cachorro era bom e pegava. Por que teve um tempo atrás, faz uns dois anos, dormiu uma capivara aqui, atrás da casa de Nilso e o cachorro nem ligou. Se fosse do tempo da minha cachorra ela nem passava da estrada pra cá que a cachorra já pegava ela de noite. 
PERGUNTA: E tem muito bicho que vai na roça também, né?

Tem. Cateto, paca, veado pra comer feijão e folha da batat-doce. Cotia pra comer mandioca. O resto não vem.

PERGUNTA: E os bichos que vem perto da casa?

Aqui vinha muito tamanduá. Eu matei muito tamanduá aqui. Muito mesmo.

DONA IRENE: Isso sem contar que a turma criava muito porco. E quando matava enchi a comer porco.

Galinha, pato. Tudo tinha. Aqui o pessoal não tinha animal grande, como boi. Boi não era costume ter. Teve uma época que a turma do finado Jango começou a criar. Mas ai eles eram meio vagabundo (risadas) e eles deixavam o bicho sair e entrava no meio das roças dos outros, bananal e destruía tudo. Era uma desgraça! Ai eles foram obrigados a acabar com isso.

PERGUNTA: Por que o pessoal ia caçar em Açungui, por exemplo?

Por que sabia que lá eles não iam perder viagem. Por que lá tinha principalmente anta e porco-do-mato.

PERGUNTA: Mas o que determina o lugar bom pra caçar?

O lugar que tem caça.

PERGUNTA: Mas como o cara sabe?

Ele sabe o lugar que tem anta, porco-domato, paca. Ele tem noção que pra lá tem caça. Ate mesmo hoje. É que ninguém vai, vai o pessoal que corta palmito pra lá. Mas se fosse permitido caçar é o único lugar que não tem como perder a viagem pra matar paca, cateto. Porco não tem mais.

PERGUNTA: Sabe que é bom pra caçar por que já conhece, já passou e conhece.

Conhece e por que é sertão, também, né? Sabe que tem mesmo caça. Por que é difícil do pessoal chegar.

PERGUNTAS: E as armadilhas, quais éramos nomes?

O pessoal fazia MUNDEL, LAÇO.

PERGUNTA: Como era o laço?

Tem vários tipos de laço: tem o laço que você faz um buraco no chão; faz uma laçada e põe ali deitada. Ai o bicho vem no carreiro e pisa ali e o laço arma e pega ele pela perna.

O laço de pegar gambá e paca: Você faz uma cerca com uma portinha, põe comida dentro e coloca a laçada na entrada em posição vertical. Quando ela vai comer o laço pega pelo pescoço.

O mundel: Você pega um toco, faz a cerca com os gravetos formando um corredor, levanta o tronco, arma ele com a armadilha em baixo no carreiro. $\mathrm{O}$ bicho vai pastando, entra na armadilha, arma a armadilha e o tronco cai em cima do animal.

O pessoal fazia também mundel apique pra pegar passarinho. É uma vara enfiada em uma raiz e envergada para cima com outra vara mais fina. Ai o passarinho vai ciscar e a vara cai na cabeça dele.

Tem a FORCA pra passarinho: Corta a embaúba, lasca uma parte da vara e abre a extremidade aberta com outra vareta. $\mathrm{Na}$ lasca que fica em baixo põe comida e amarra 
uma corda que passa pela lasca de cima. Quando o passarinho pousa pra comer o cara puxa a corda e junta as duas lascas no meio do pescoço do bicho, que cai morto.

E a ESPARRELA: Em uma ripa faz dois furos onde em um amarra a corda e em outro uma fruta de isca. Na corda faz um laço e coloca em uma vareta em frente a ripa, posicionada como um poleiro, onde o passarinha pousa para comer a fruta. Quando o passarinho pousar na vareta ela pende e o laço corre pegando o passarinho pela pata.

ARAPULCA - Gaiola de madeira trançada na forma de um quadrado afunilado até fechar em cima (como uma pirâmide). Arma com um graveto levantando um dos lados da armadilha com uma comida na parte de baixo. Quando o passarinho vai comer, o graveto é deslocado e prende o animal.

PERGUNTA: Tinha muita armadilha de passarinho, né? E tem as armadilhas de tatu também?

É depois o pessoal inventou muitas armadilhas que não tinham, né? O pessoal inventou o Jequi, inventou a rede.

JEQUÍ - é uma armadilha que coloca na toca do bicho feita de arame. Prende a boca da armadilha na toca do bicho e deixa o fundo afunilado em pé, posicionado apenas com um graveto leve, onde prende a tampa também levantada por um fio. Quando o tatu sai da toca e entra na armadilha o graveto libera o fio que solta a tampa fechando a armadilha com o bicho dentro.

REDE - Coloca a rede na boca da toca, com o laço armado à poucos centímetros da boca e amarrado em um galho de árvore. Quando o tatu entra na rede desarma o laço que fecha a saída da rede, deixando a rede pendurada na árvore, com o bicho dentro.

E tem uma armadilha perigosa que o pessoal inventou pra pegar capivara. É uma espécie de ratoeira aberta com dentes nas beiras. Colocada na beira da água, onde o animal vai beber água. Quando ele pisa a armadilha fecha na pata dele, prendendo ou arrancando a pata.

PERGUNTA: Agora, o Senhor disse que antes todo mundo caçava, que era difícil uma família que não tinha uma carne secando no fogo, né? Então, como a proibição da caça se refletiu na comunidade do Mandira?

O que acontece é que o pessoal parou de caçar. Parou de caçar no sentido de ser livre pra caçar. Por que todo mundo caça: mata um tatu, mata uma paca, isso o pessoal caça mesmo, não tem jeito. Só que é proibido e não tem mais nada. Antigamente não era proibido era livre, o pessoal andava com a espingarda nas costas e tinha caça a vontade, tinha caça, tinha passarinho, tinha tudo, por que o pessoal respeitava a época da criação do bicho. Hoje não se pode caçar, mas ninguém respeita nada. O pessoal caça o ano todo. Se mata uma paca com cria, se mata um tatu com cria, um quati com cria. Então hoje não tem mais caça. Você anda por esse mato e não vê um rastro de tatu. Antigamente tinha lugar que era igual uma cerca de galinha assim, tudo limpo do tatu mexer. Hoje você não encontra isso.

PERGUNTA: Ou seja, antes que era livre pra caçar e todo mundo caçava tinha mais caça. Hoje em dia que...

Ninguém caça... diz que ninguém caça, não tem mais nada. Por que antigamente o pessoal respeitava a época de criação do bicho. $\mathrm{Na}$ época que tava criando eles não matavam. Eles caçavam outro bicho, como o porco-do-mato, o cateto. Por que cateto e porco-do-mato cria o ano todo, não tem época, então pode caçar o ano todo também. 
Agora paca, veado, tatu, quati tem a época certa que é de agosto até dezembro. Nessa época não pode caçar esses bichos.

O que acontece é que hoje o cara tá mais preocupado com a proibição da caça do que com o bicho. Então ninguém tem mais respeito.

PERGUNTA: E a pesca Seu Chico, era bem diferente da que é feita hoje?

Era.

PERGUNTA: Quais foram as mudanças?

Mudou que antigamente tinha muito peixe. Como a tainha: o pessoal não usava rede, usavam um pedacinho de rede amarrado na cintura dentro da canoa com um facho de taboca no bico da canoa. Chegava no poço batia no fundo da canoa com o remo e a tainha pulava, batia na rede e caia dentro da canoa.

O bagre, o robalo - também tinha muito bagre. O pessoal dava um lance de arrasto. A pessoa caia com água pelo peito, jogava a rede e ia puxando pela corda até chegar no seco. Assim pegava muito peixe. Ai depois foi inventado a rede de lanço mesmo... e a coisa ficou como está hoje: praticamente não pega nada. Ai a malha que era maior ficou menor, e menor, e menor... e hoje tá pegando praticamente o filhote ai não tem o peixe grande pra criar, né? Antigamente tinha e não precisava muito. Ninguém tinha rede como tem hoje em dia. A única rede que tinha era de arrastar. Rede feito na mão de chumbo, de pedra.

As armadilhas que usavam eram o covo e o juquiá, ambos de água doce.

O covo tem uma boca com o filho dentro. E é arrumada na água com a boca virado para onde a água corre.

O juquiá também é de taquara, mas começa fino, tem uma barriga com um gargalo mais fino e uma boca aberta. Não tem filho. A boca fica posicionada contra a correnteza. O peixe entra e não consegui sair.

PERGUNTA: E pega qualquer tipo de peixe?

Não. Pega mais bagre e traíra. E acará.... pega robalo também. É para peixes de água doce.

PERGUNTA: E o jaca, o que é o jacá?

É um cesto de timbupeva usado pra carregar coisas da roça, pra carregar peixes da maré também.

PERGUNTA: Como é o nome da bacia feita da raiz da figueira?

Gamela. Da raiz da figueira faziam bacias redondas, mas as gamelas compridas faziam de madeira.

PERGUNTA: Quais outros cestos são feitos aqui no Mandira Seu Chico?

O Jacá e o cesto que agente trabalha pra tirar ostra. Todos feitos de timbupeva.

PERGUNTA: Cesto com nome só tem o Jacá?

Só.

PERGUNTA: E o Jacá é o cesto de colocar nas costas?

É. De colocar nas costas, de colocar no burro. Carregavam as crianças dentro do jacá.

PERGUNTA: E as tranças dos cestos tem nome? 
Tem o trançado simples e o picho.

PERGUNTA: Mas o cesto com trançado de picho tem algum significado ou uso diferente dos outros cestos?

Não! É só que tem um trançado diferente. É só questão de querer fazer o trançado do picho.

PERGUNTA: E o Senhor aprendeu com quem esse trançado Seu Chico?

Eu aprendi sozinho. Só vendo os mais velhos fazendo.

PERGUNTA: Como é feito?

Começa pelas linhas mestras na base e depois vai crescendo até chegar em cima. O processo de fazer os cestos são os mesmos. Tanto do jacá quanto do cesto redondo o processo é o mesmo. O que diferencia é o formato da base que determinam a saída das linhas mestras. O jacá a base é cumprida e fina, enquanto o outro cesto a base é meio quadrada pra ter o corpo redondo. 


\title{
TERMO DE CESSAOO GRATUITA DO
}

\section{USO DA IMAGEM E DEPOIMENTO}

\author{
Venho por esta conceder o uso da imagem e \\ depoimento, concedido a Fabio Guaraldo Almeida, a fim \\ de contribuir com suas pesquisas no território Mandira.
}

Iren candida mandira coutumo

Irene Mandira 


\section{Entrevista com Dona Irene}

\section{PERGUNTA: Quais são as festas que tem na comunidade?}

A festa da ostra e a festa de Santo Antônio.

PERGUNTA: Antigamente tinham outras festas?

Não. Antigamente tinha só a festa de Santo Antônio. Na época do meu pai tinha também a quaresma, só que não era festa era reza. Costumavam rezar a quaresma toda, mas era só reza, a única festa que tinha era de Santo Antônio. E mesmo assim ela era diferente de hoje: Tinha o terço cantado no dia 12, depois servia um café pro povo e a noite cada um trazia um pouco de alimento e todos compartinhavam. Ai quando era cinco horas da manhã faziam a alvorada. A alvorada era o terço cantado e depois faziam um café para dar pra turma. Era tudo de graça, compartilhado entre todos. Eu e minhas tias fazíamos a bruinha pra levar.

Hoje, como tudo é diferente, agente faz o terço cantado só no dia 12 as oito horas da noite e depois tem o bingo e o baile, onde as coisas são todas vendidas. Se quer comer tem que comprar. Ai no dia seguinte tem a procissão as dez horas seguido da missa.

PERGUNTA: E hoje vem gente de fora?

Mas antes vinha também. Não de muito longe, mas da redondeza vinha bastante gente. A diferença é que cada um que vinha trazia alguma comida pra compartilhar todo mundo junto. 


\title{
TERMO DE CESSÃO GRATUITA DO \\ USO DA IMAGEM E DEPOIMENTO
}

\author{
Venho por esta conceder o uso da imagem e \\ depoimento, concedido a Fabio Guaraldo Almeida, a fim \\ de contribuir com suas pesquisas no território Mandira.
}

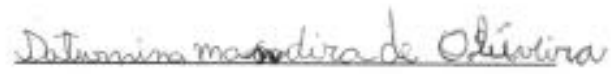

Saturnina Mandira 


\title{
TERMO DE CESSÃO GRATUITA DO USO DA IMAGEM E DEPOIMENTO
}

\author{
Venho por esta conceder o uso da imagem e \\ depoimento, concedido a Fabio Guaraldo Almeida, a fim \\ de contribuir com suas pesquisas no território Mandira.
}

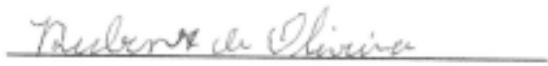

Rubens de Oliveira 


\section{Entrevista com Dona Saturnina e Seu Rubens}

\section{PERGUNTA: Onde é ?}

Dona Saturnina: No poste de luz .

PERGUNTA: CTI?

Dona Saturnina: É

PERGUNTA: É antigo!

Senhor Rubens : O primeiro é difícil agora é quase tudo, daqui no estrangeiro você fala com quem você quiser lá .E antigamente era só por fio mesmo.

Dona Saturnina: É meu irmão trabalhava com o barco dele na linha ai , quando dava defeito, meu guru, e nessa época andava tudo descalço .Ele andava nesse brejo com a calça arregaçada assim aqui ...

PERGUNTA: E não tinha bota ?Não tinha nada?

Dona Saturnina: Não nesse tempo ninguém usava bota, era só descalço.

PERGUNTA: E cada um aqui, agora aqui é tábua .

Dona Saturnina: É triste assim como você ta falando

PERGUNTA: E não tinha essa rua que você está falando ?

Dona Saturnina: Não, não tinha nada .

Senhor Rubens :Aqui a rua que tinha era só canoa e mais nada .O pessoal tudo morava na beira do rio.

Dona Saturnina: Na beira do rio só.

Senhor Rubens :Não tinha nada, nada ,nada.

PERGUNTA: Mas essa trilha já tinha?

Dona Saturnina: Não.

PERGUNTA: Só trilinha?

Dona Saturnina: Não tinha .

PERGUNTA: Não tinha!

Dona Saturnina: Depois de ...Depois que nós casamos?

Senhor Rubens :Foi

Dona Saturnina: Depois que nós casamos, cinqüenta anos atrás.

PERGUNTA: Vocês casaram cinqüenta anos atrás?

Dona Saturnina: Cinqüenta e dois, cinqüenta e três anos de casados, e então que eles começaram esta trilha . essa trilinha ai,

PERGUNTA: Dona Saturnina fala o seu nome, só pra ...

Dona Saturnina: Saturnina Mandira de Oliveira . 
PERGUNTA: E do Senhor?

Senhor Rubens :Rubens de Oliveira .

PERGUNTA: Seu Rubens. Vocês casaram quando Dona Saturnina?

Dona Saturnina: Eu não me lembro o ano

PERGUNTA: Mas com quantos anos vocês casaram ?

Dona Saturnina: Eu não me lembro .

Senhor Rubens :Só por documento.

Dona Saturnina: Eu sei que faz 50 anos .

PERGUNTA: Mas ai o Seu Rubens morava aqui e a Dona Saturnina morava lá no sítio...

Dona Saturnina: É .

PERGUNTA: Se conheceram nas festas?

Dona Saturnina: É.

Senhor Rubens :Eu mesmo, meu pai morava mais lá na frente, lá na frente, bem no começo, no meio do sítio onde tem o porto .

PERGUNTA: Ah, ta!

Senhor Rubens :Por que esse porto aqui, chama Porto do Meio, o sítio aqui chama Porto do Meio.Por que é Porto do meio? Por que o primeiro porto que tinha era o Mandira .

PERGUNTA: Que era aquele ali?

Dona Saturnina: Isso, aquele ali .E depois seguia o rio e tinha o Porto do Meio que é o Porto do meio, ai passava pra cima era o rio da Mina, lá já o porto do Rio da Mina lá em cima , assim.

PERGUNTA: Então esse era o porto mesmo?

Senhor Rubens :É, Porque o porto nosso era o porto do meio.

PERGUNTA: E o pessoal conhecia aqui, como Porto do meio.

Senhor Rubens :Isso.

PERGUNTA: Ou seja, todo mundo conhecia pelo nome do porto ?

Senhor Rubens :Isso! Porto do meio.

PERGUNTA: Não tinha fazenda ?

Dona Saturnina: Não, não

Senhor Rubens :Isso Porto do meio.

PERGUNTA: ah daí tinha o porto do rio das Minas e o Porto do Mandira por causa do Rio Mandira?

Senhor Rubens :Isso, é .

PERGUNTA: E aqui é o porto do meio ?

Dona Saturnina: É o Porto do Meio. 
PERGUNTA: Ah ta, era mais por causa da ...

Dona Saturnina: E nos moramos no meio.

PERGUNTA: E o nome do pai do Senhor?

Senhor Rubens :Antônio Leandro de Oliveira .

PERGUNTA: Antônio Leandro de Oliveira?

Senhor Rubens :É e o irmão dele era Juscelino de Oliveira .

PERGUNTA: E quem é o primeiro que teve aqui as terras aqui do porto do meio?

Senhor Rubens :O sítio mesmo era do meu avô, Benjamin Constâncio de Oliveira, era o dono do sítio que era o pai do meu pai.

Professor ele.

PERGUNTA: É né !

Senhor Rubens :Você veja o que é as coisas, agente assiste televisão.Tem ainda a assinatura dele na caderneta dele, tudo é escrito com pena de galinha .

PERGUNTA: Era professor?

Senhor Rubens :É professor, então molhava ali e escrevia .Não existia aquela caneta. È o que sempre assiste ai na televisão.

PERGUNTA: E ai sempre conviveu com o pessoal do Mandira?

Senhor Rubens :O Porto do Meio é aliado com a Mandira de tudo, porque se você quisesse fazer uma roça, antigamente não existia isso ai e eu acredito que era uma comunidade, porque se precisasse fazer um orditório nos íamos lá , ia lá ao Mandira e convidava oito, dez quinze pessoas agente dava comida, e vinha todo aquele povo um dia fazer uma roça, fazia uma roça ali pra aquele lado.

E quando eles precisavam lá, nos íamos daqui fazer a mesma coisa lá, é tudo combinado.

PERGUNTA: E a família era grande também né ?

Senhor Rubens :Era grande, ô! A Mandira ai embaixo era grande, era uma família grande mesmo.

PERGUNTA: Era né !

Senhor Rubens :Agora nós aqui éramos poucos, eram dois irmãos só que moravam.Aqui ocorreu a revolta e depois da revolta o mais novo foram embora.A minha avó com filho foi para São Paulo.

PERGUNTA: Depois da revolução, da revolta de 32?

Senhor Rubens :Isso, depois estudaram lá , um estudou para engenheiro, foi assim se formaram lá.Ficou só dois irmãos aqui e depois da revolta não deu para ficarem ai , pois perderam tudo.Aí foram para outro sítio lá na Vila Beira Mar, lá na Cananéia pra baixo do Ferrabório, bem pra baixo, um sítio lá 45 alqueire. Aí mudamos para lá e eu nem havia minha mãe que falava com o meu pai, porque não dava para suportar mesmo, $o$ mau cheiro ai e fomos embora . Depois de muito tempo que voltamos para cá , no sítio, ai nunca mais saímos .Ai o outro saiu, meus irmãos casaram, saíram também, aí só ficou eu .

PERGUNTA: Só ficou o senhor? 
Senhor Rubens :Eu e o outro meu o primo que morreu agora esses dias .Ai ele também vendeu a parte dele né, tudo e só ficou eu que não vendi, e to aqui ainda, ainda não sai e acho que daqui agora só saio quando for pra sair de verdade .

PERGUNTA: E não sai mais .Também o Senhor casou e fícou aqui , foi casar com uma mendirana.Aí acabou ficando.Né dona Saturnina? Não ia ter como sair .

Dona Saturnina: Não tinha não

PERGUNTA: E vocês são casados há cinqüenta anos então ?

Dona Saturnina: É cinqüenta anos de casados .

PERGUNTA: Na época da fazenda onde morava o pessoal do Mandira?

Dona Saturnina: Do Mandira, morava um pouco ali perto da casa de pedra, o Francisco morava ali embaixo.

PERGUNTA: Já morava ali?

Dona Saturnina: Já morava lá embaixo.

PERGUNTA: Do lado do Sambaqui?

Dona Saturnina: Isso! Ao lado do Sambaqui e o meu tio morava la onde viram a coisa de farinha .Ele morava lá e lá que ele faleceu.Seu João.

PERGUNTA: E foi lá que ele faleceu ? Mas antes dele ir para lá ele também morava para cá.

Dona Saturnina: Ele morava ali em cima .

PERGUNTA: Na casa de pedra?

Dona Saturnina: É ele morava pra cima da casa de pedra .

PERGUNTA: Todo mundo morava pra cima da casa de pedra?

Dona Saturnina: É.

PERGUNTA: Falaram que ele morava ali e depois que teve o orfanato e ele foi pra lá.

Dona Saturnina: Foi.Era o padre que morava lá , o padre chamava padre João ai ele trouxe um bocado de criança, até nos plantamos uma roça de mandioca ali, de abóbora demais , umas abóboras todos os abóbora assim e eu com Reinaldo, ainda era pequeno eu levava para vender abóbora pro padre para ele dar para essas crianças, ai depois que o padre foi embora foi que meu tio foi para lá.

PERGUNTA: A Senhora nasceu lá do lado onde é a atual escola?

Senhor Rubens :Não nasceu já pra baixo.

Dona Saturnina: Eu nasci naquela casa ali pra baixo, não tem o Sambaqui , então aquela casa era de papai era e frente ao Sambaqui aqui pra baixo na direita de quem vai, e foi ali que eu nasci.

PERGUNTA: Um nasceu ali, que dava pra lá do Porto descendo já da pro Porto?

Dona Saturnina: Isso!

PERGUNTA: Ali deveria ser, como que era aquela região ali?Deveria ser igual aqui, mais ou menos roçado assim. 
Dona Saturnina: Não naquela época era tudo mata virgem, tinha mato bastante mato . Então quando eu fazia roça ,então não tinha nessa época ,como não tinha coisa de floresta essas coisas, a pessoa fazia roça na porta, na porta roçava fazia assim pra plantar arroz.

PERGUNTA: Na frente da casa?

Dona Saturnina: É na frente da casa, plantava na frente da casa.

Senhor Rubens :Por que não tinha criação.

Dona Saturnina: Nós nunca criamos gado, nós criávamos galinha, pato, essas coisas que nós criávamos.Então na roça dele arroz essa coisas, agora que eles tinham que fazer roça longe por causa do gado.Toda vida eles criaram a criação

PERGUNTA: Mas lá era assim então a casa era aqui e a roça era tudo aqui e tinha outra casa aqui e o filho fazia a casa perto.

Dona Saturnina: Isso, igual compadre Florindo que é o avó dele a casa dele era pertinho assim.

PERGUNTA: A casa dele pertinho?

Dona Saturnina: Pertinho demais.

PERGUNTA: Dava para ver assim .

Dona Saturnina: Isso pertinho demais.Nós morávamos mais para baixo e ele morava mais para cima um pouquinho assim.

PERGUNTA: Por que hoje em dia é só mato lá né?

Dona Saturnina: É só mato .

PERGUNTA: Antigamente deveria ter mais roça para fazer arroz.

Senhor Rubens :Por que o mesmo lugar da casa é a roça.não faziam assim roça com pastagem .Pra falar a verdade a mata é tudo grudado assim perto da casa .

PERGUNTA: É mesmo?

Senhor Rubens :É

PERGUNTA: A Senhora tem lembrança de histórias do seu vô, da sua mãe falando de quando ainda era fazenda aqui de quando o pessoal ainda trabalhava com essa descendência da fazenda do senhor Andrade?

Dona Saturnina: Olha do meu avó não lembro.

PERGUNTA: Mas eles contavam história dessa época?

Dona Saturnina: Da minha vó eu lembro que da minha mãe eu lembro por que nos trabalhávamos junto com ela, enquanto ela era forte ela trabalhava junto com nós.

PERGUNTA: E ela contava histórias dessa época?

Dona Saturnina: Ela contava história da Selestina com o como é que é o nome do menino, esqueci do nome dele.

Senhor Rubens :Eu não conheci.

Dona Saturnina: Eu também não conheci.

Senhor Rubens :Ela pra sair de casa... 
Dona Saturnina: Antônio Florença de Andrade.

Dona Saturnina: Isso. Dali da casa de pedra até o Mandira era feita uma estradinha e mamãe contava que para levarem ela dali da casa, de lá do porto até a casa de pedra.

PERGUNTA: De qual porto?

Dona Saturnina: Do porto de Mandira que flava do porto de fora. Daí de lá para levarem ela em casa tinha que ter a carroçinha para levarem ela porque ela não andava por que ela era muito grande.

PERGUNTA: Quem era muito grande?

Dona Saturnina: A Celestina Andrade.

PERGUNTA: A Selestina era a mulher do seu Andrade?

Dona Saturnina: É do Andrade, é então tinha que levar ela de carroça até lá em Mandira ai depois quando iam levar ela pra fora pra canoa levavam ela de novo outra vez, por que ela não andava e ela era muito grande, gorda.E o outro era rico, né vazia os outros de bobo, fazia os escravos de ...

PERGUNTA: Ela era mais velha do que o senhor Florentino de Andrade ou não?

Dona Saturnina: Do que Florindo?

PERGUNTA: É.

Dona Saturnina: Ai era moça nova ainda quando via ela .

PERGUNTA: Não do a ...

Senhor Rubens :A mulher que você diz, é a mulher que é mais velha do que o homem?

PERGUNTA: É.

Senhor Rubens: Dai eu não posso dizer nada por que eu não conheci.

Dona Saturnina: Não sei.

PERGUNTA: Mas eu acho que era pelo que eu estou vendo lá nos documentos escritos era sim.

Dona Saturnina: Acho que deveria ser

PERGUNTA: Acho que ela era uns dez anos mais velha do que ele.

Senhor Rubens :Devia ser .

Dona Saturnina: Acho que sim .

PERGUNTA: E o que mais que ela contava dessa época ai que a senhora lembra? Quer dizer então que a trilha pro porto era uma trilha grande, porque dava para ir de carroça?

Dona Saturnina: É era uma trilha grande .

Senhor Rubens :É por que eles já faziam estrada própria .

PERGUNTA: E as casas do povo era o que na beira da estrada?

Dona Saturnina: Na beira do caminho assim na estradinha, no caminho que eles moravam . Que nem nessa época eles moravam, não sei se era nas areias .Parece que era nas areias que eles moravam lá , só que ...

PERGUNTA: Onde que é as areias? 
Dona Saturnina: Lá em frente onde o Leonardo mora .

Senhor Rubens :Em frente à escola

PERGUNTA: Enfrente a escola é as areias?

Dona Saturnina: É lá pra dentro.

PERGUNTA: Pra dentro perto do mangue?

Dona Saturnina: É

Senhor Rubens :É perto de onde nós fazemos a roça .

PERGUNTA: Ah ta, pra lá é as areias, do lado direito do rio?

Dona Saturnina: Isso.

Senhor Rubens :E vai lá pra dentro.

Dona Saturnina: Lá pra dentro.

PERGUNTA: E quem morava ali?

Dona Saturnina: Morava meu avô, lá a família Mandira morava lá , vovô com a família, nas areias.Então depois que ele morreu, as famílias casaram e mudaram pra cá. No lugar mais na beira do rio.

PERGUNTA: E porque que chamava as areias ali?

Dona Saturnina: Por que lá, pra cá é só barro, e lá é só areão, a areia é fininha pra gente planta.

Senhor Rubens :Igual Cananéia .

Dona Saturnina: Então colocaram areia, eu acho que deve ser por causa da areia.

Senhor Rubens :A areia é branca.

Dona Saturnina: É a areia é bem branca.

PERGUNTA: E lá tem casa de pedra também?

Dona Saturnina: Lá tinha .

PERGUNTA: Tinha?

Dona Saturnina: Lá tinha casa de pedra, tinha jabuticabeira, tudo tinha lá.

$18 \mathrm{~h} 33 \mathrm{~min}$ até $20 \mathrm{~h} 00 \mathrm{~min}$ comentam sobre onde fica o pé de jabuticaba e mexerica

PERGUNTA: Mas na época que eles moravam la em baixo já tinha o porto do Mandira ainda ou não?

Dona Saturnina: Tinham

PERGUNTA: Tinha por que era da casa do seu Andrade?

Dona Saturnina: Isso, tinha.

PERGUNTA: Ah sempre usou aquele porto ali ?

Dona Saturnina: Sempre usaram aquele porto . 
PERGUNTA: E a casa de pedra era usada para que?

Senhor Rubens : Olha o que me falavam era que era a moradia deles, mas só que tem uma coisa.A moradia, mas só que dentro da moradia deles eles faziam um engenho.

Dona Saturnina: Tinha um engenho.

Senhor Rubens :Um engenho de arroz .

PERGUNTA: Mas dentro da casa?

Senhor Rubens :Dentro da casa, por que essa aqui do Mandira tinha .Aqui no nosso sítio tem isso ai também. Tem duas casas de pedra só que já foi desmanchada, por que nós saímos né .Por que eu mesmo nasci na mesma casa ainda .

PERGUNTA: Nessa casa?

Senhor Rubens :Na casa de pedra .Eu nasci numa casa bonita, grande, bem grande e então essa daqui , dali do Mandira ela puxa água da cabeceira dessa cachoeira que passa bem aqui na ...

PERGUNTA: É agente mapeou a área. Agente tentou chegar na cabeceira, mas não conseguimos. Agente subiu, subiu, subiu... quando eu vi não tinha dado 200 metros de caminhada.

Senhor Rubens :Só quem vê a trilha de onde ele pegava água .Olha todo o acúmulo que faz o espigão ela acompanha.

PERGUNTA: Agente viu a valeta trazendo água .Agente só andou uns 200 metros .

Senhor Rubens :Isso, ela puxa na rolda para pilar arroz.Era a mesma coisa tudo nessa casa era assim.

Por que o meu bisavô era um homem de muito dinheiro, mas dinheiro era só ouro.Ele trabalhava com o negócio de ouro no tempo dos jesuítas, na mina ele tirava muito ouro. Ele tinha muito terreno por aqui.

O morrete mesmo era dele, o rei da mina mesmo era do meu bisavô, lá tem um morro.

PERGUNTA: Seu bisavô o seu Benjamin o senhor diz?

Senhor Rubens : Na casa não na chapada, lá no morro ele tinha a casa dele de lá eles arrumavam à corrente , mas uma corrente, eu cheguei a ver, muitas vezes no caminho saindo lá da cachoeira do rio da mina.

Mas uma corrente boa para amarrar a canoa, por que lá da cheia e da muita poça, então pra não tira a canoa ...

Só que lá a turma ia só por que tinha dinheiro.

PERGUNTA: Saia atrás de ouro?

Senhor Rubens :Rapaz, muita gente corria de lá, até hoje tem gente que ainda força pra ir lá mas não tem coragem.

E ele então trabalhava com os jesuítas, com os padres pra tirar o ouro e le e que era o chefe, só que tinha um negro grande que meu avô falava pro meu pai, que meu pai contava já para nós .E em uma ocasião então ele ficou doente, meu bisavô e saiu foi para Falcão Bonito e deixou o preto tomando conta, e esse preto tirava o ouro com a turma lá e escondia um pouco, escondia um pouco.E nessa fuga dele aí, ele fugiu, caiu fora .Aí os padres vieram porque estavam com a chave e quem que iria entram naquele lugar? Não tinha condições de abrir a casa .Eu sei que ficou nessa conversa. E eles 
tiravam o ouro e enterravam lá .Dizem que tem três barris de ouro, mas a turma pensa que é barril de não sei o que lá e que ta dentro de um ... por que tem uma pedra muito grande lá bem na chapada do morro, na cabeceira do Rio da Mina ,esse Eliseu Martins sabe de tudo certinho lá . É feito tudo de pedra lá, o caminho assim para ir lá é tudo feito de pedra e vai embora .

Essa pedra tem uma porta que só ele que sabe mesmo, mas que a coisa é muito bonito.

Então ele levou um lá para tirar, até tentou com bomba .E ele não ta lá ...

PERGUNTA: Rio da Mina tem história também.

Senhor Rubens :E o ouro não ta lá, o ouro está no mapa, está no mapa em três barrica, só que cada barrica tem uma alavanca marcado.Um caçador que passou lá viu essa alavanca, mas ele ia saber que estava enterrado ali? E foi embora . Ele contou muitas vezes pra nós isso daí. Mas quem vai lá?...

PERGUNTA: No meio do mato.

PERGUNTA: Agora, aqui na fazenda do seu avô Benjamin também tinha escravo ou não?

Senhor Rubens : Tinha.

PERGUNTA: Mas era igual à fazenda do seu Andrade?

Senhor Rubens :É.

PERGUNTA: E para onde foi o povo que estava aqui?

Senhor Rubens : Depois que ele faleceu ficou meu pai e meu tio morando aqui. Depois eles casaram e nós já fomos crescendo, fomos crescendo, fomos crescendo, aí ficamos tudo ai... os que resolveram sai pra fora para estudar e os que não saíram ficaram.

PERGUNTA: Porque nos Mandira o pessoal ficou.

Senhor Rubens :Isso, ficou.

PERGUNTA: Mas porque o pessoal ficou no Mandira?

Dona Saturnina: É por causa do sítio .O sítio mesmo era, o pessoal mesmo era Vicente .Família Vicente, mas como eles queriam que ficasse com o Mandira, aí o velho arrumou Geraldo Mandira .Era Vicente Mandira, tudo era Vicente Mandira, aí já os nossos pais em vez de arrumar Vicente já não arrumaram mais.Só arrumaram Mandira. Então nós assinamos com o nome da terra. Por que o terreno é Mandira e nossa assinatura é Vicente, só que eles não arrumaram, só o mais velho Tio Chiquinho, João, e João Vicente Mandira, Francisco Vicente Mandira, só que nós não arrumaram, nossos pais não arrumaram .

A minha sobrinha essa Joracina, ela trabalhava em Salto, quando ela descobriu que a assinatura era Vicente, ela queria tirar o Mandira e arrumar Vicente. Mas como que ia arrumar? Foi procurar lá em Salto, foi no cartório pra ver se mudava Vicente e tirava Mandira , mas não teve jeito .mas agora nossa assinatura é Mandira tem que ficar né? Ficou Mandira .

Senhor Rubens :Essa terra ai tinha o Vicente Mandira e o Antônio Mandira, mas esses dois que brigavam .Mas só que não brigavam de tapa brigavam na questão.

PERGUNTA: Mas quem que era os dois?

Dona Saturnina: Eram primos. 
Dona Saturnina: Meu avô era João Vicente e Antônio Mandira era primo de vovô.

PERGUNTA: Os dois eram filhos de Francisco?

Dona Saturnina: É . Um era filho de Francisco e o outro era filho de... Como é que era o nome do pai dele ?Ai como que era o nome do pai dele ?Esqueci agora. Minha cabeça deu um branco.Então ele morava lá no Salto.

PERGUNTA: Mas eles não eram os dois filhos do Francisco o herdeiro da terra o que ganhou a terra por doação?

Senhor Rubens : Não sei como que era, só sei que os dois brigavam .Porque um queria tomar lá . e o outro também queria e eles sempre brigava,.

PERGUNTA: Queriam o que?

Senhor Rubens: Queriam o Salto do Mandira.

PERGUNTA: Os dois queriam o Salto do Mandira?

Dona Saturnina: É. O Antônio morava lá, pai deles o finado Miles, então morava lá.E o meu avô morava aqui embaixo, só que meu avô queria pegar o Salto do Mandira.

PERGUNTA: E lá que você dia é na trilha do Pindaúba?

Dona Saturnina: Isso na Trilha do Piandaúba, do seu Valério.

PERGUNTA: Aquelas esteiras que agente viu, aquelas partes planas que agente viu.

Dona Saturnina: É então...

\section{Fita 2:}

Dona Saturnina: Por que ele morreu e ficou Miles, e Sipião. Ai Sipião foi embora pra Jacupiranga e Miles morreu ai mesmo.

PERGUNTA: Então o Antônio morava lá em cima?

Dona Saturnina: Lá em cima, então meu avô queria pego lá em cima. A divisa era mais aqui em baixo, e meu avô arrumava a divisa lá em cima. Lá onde tiraram pedra pra fazer cascalho pra fazer ali pra tomar banho. Então ali no salto. A divisa e bem ali na subida aqui , não tem uma aguinha que sobe pra uma pedrinha ? Então a divisa é ali. Mas só que meu avô arrumava lá em cima, e quando ele arrumava lá em cima Antônio Mandira arrumava aqui em baixo.

PERGUNTA: E eles na verdade queriam o Salto?

Dona Saturnina: É o Salto.

PERGUNTA: O Antônio morava do lado do Salto?

Dona Saturnina: Morava do lado do Salto, morava lá em cima.

PERGUNTA: Ele morava mais pra cima?

Dona Saturnina: É mais pra cima. Agora não me lembro se os dois eram irmãos .Não posso me lembrar.

Senhor Rubens: Acho que eram primos.

Dona Saturnina: O Flamino era primo. 
Senhor Rubens: Eu sei que eles brigavam. Meu Deus eles iam lá de Cananéia até a praia , e nesse tempo não existia ... Iam lá à praia pra Iguape pra praia. $\mathrm{O}$ advogado deles morava em Santo.E eles iam até Santos pra ver se ganhavam na questão. Papai corria léguas dele. Quando ele ia lá ao Porto, lá no sítio lá, morava lá no Cananeu, eu era pequenininho assim, eu dizia assim seu Vicente vem vindo lá. Ai meu Deus ele pode pegar agente de testemunha pra polícia.

Ele chegava em casa: "Seu Antônio não ta?" "Não. ele saiu, foi lá pra roça." "Ah eu queria falar com ele." "Ah agora você não fala , ele só chega de tarde." Ai ele tocava e ia embora, era assim.

E Antônio Mandira chegava no outro dia, João Vicente já passou aqui? Já. Ah ta.

Ele passava assim com jaca nas costas e outro na cabeça. Cheio de caça era pato, era tatu, era quati , era anta, era tudo, tudo o que caça ele matava e arrumava.

Naquele tempo todo mundo era liberto, eu mesmo muitas vezes andei com a espingarda nas minhas costas, pra arrumar. O pessoal da venda que vinha negociante cada um tinha a sua espingarda pra matar essa pombasinha assim que canta.

\section{PERGUNTA: Macuco?}

Senhor Rubens: É isso, então ele levava aquele cesto de carne pra Cananéia e ele vendia tudo aquilo para com o dinheiro trocar questão.

Trocar questão pra esse negócio de sítio ai. Era direto isso ai.

O remo dele, rapaz! Ele chegava lá no sítiosinho onde ele morava... uma casa no alta... ele arrumava assim... olhe, tinha 2 a 3 metros de capo, pra ele andar só remando. Ele arrumava a canoa na cabeça e subia aquele caminho do salto do Mandira.

Luis: O pessoal conta que ele pegava a canoa nas costas e o remo dele ninguém agüentava.

Senhor Rubens: Isso exatamente, eu cheguei ver. O povo contava, ele cozinhava canjica dois dias para levar para papai lá no nosso sítio .Por que ele gostava do papai demais da conta, o velho era uma beleza. Agora o Vicente era ruim

PERGUNTA: Que velho? Qual velho?

Dona Saturnina: O Antônio Mandira que era muito bom, que gostava do meu sogro. Já meu avô não gostavam dele.

Senhor Rubens: É verdade, eu era pequenininho.

PERGUNTA: Mas quem tinha a canoa era seu João? Ou seu Antônio?

Dona Saturnina: Os dois tinham canoa.

PERGUNTA: Mas quem carregava a canoa de dois metros?

Dona Saturnina: Era o Antônio

Senhor Rubens: Era o Vicente que não gostava que deixassem a canoa no canto deles, o coitado do Antônio Mandira subia aquele rio ali da ponte... que tem ali ele... subia aquele rio seco, ia com a canoa lá em cima no João Tomas, o homem que morava ali, quase na pedreira lá.

Luis: Bem ali onde agente tira areia agora.

Senhor Rubens: Isso 
Luis: Ali onde estávamos pescando.

Senhor Rubens: Isso. Ali ele deixava a canoa ali.

PERGUNTA: No primeiro poço de agente parou?

Senhor Rubens: Quando estava muito seco ele colocava na cabeça no ombro assim e tocava para baixo, era assim. Mas a briga deles era assim , na questão.

PERGUNTA: Quer dizer que quem carregava a canoa nas costas eram os dois?

Dona Saturnina: Não era só um, seu Antônio. O João já tinha o porto dele aqui em baixo e já deixava aqui em baixo.

Senhor Rubens: Ele vinha de la do sítio dele. Uma vez o papai encomendou um cachato , o cachato é um porco né , ele pegou esse cachato lá pra não passa ali pro Mandira, ele pegou esse cachato lá e o cesto de carne de caça ele subiu ali por cima, não sei onde era ali, subiu, e saiu ali onde era a casa de papai com esse cachato e um cesto de carne na cabeça. A espingarda dele era preta.

Luis: Acho que o porto que titio fala é o que titio ainda usa, ou não ta usando mais?O porto de fora ali.

Senhor Rubens: Usamos ele.

Dona Saturnina: Ali onde nós fazemos o porto de fora, porque o nosso porto da uma canoa, mas o ali era o porto do Ribeirão, mas o porto de fora é ali onde tem a ponte. Ali na plantação dele dali pra lá que tem o cuco, na berada de Caratuva.

Luis: Faz tempo que eu não vou pra lá.

Dona Saturnina: Então, ali que era o porto do Mandira

Senhor Rubens: Ali onde tem a banana

Luis: Depois que vocês entraram ali não vi mais. Eu mesmo só fui la, até o rio com a professora só .Mas eu mesmo depois que eles entraram ai.

Dona Saturnina: Aquele ali que desce pra baixo é o primeiro agora que seco né ficou feito uma lagoa pra cima, então ali que era o porto de Fora.

Senhor Rubens: Porque o rio da mina passava no porto da Mandira, o rio da mina e depois que começou a tirar caxeta ai, ele fez com a enxada um a linha assim, pra caxeta sair mais fácil por que a caxeta bóia e rapaz deu uma enchente. Essa enchente rapaz não saiu lá no Caiatuba .

Luis: Éh! Papai contou.

PERGUNTA: Agora essa caxeta o pessoal deixava no meio do rio?

Senhor Rubens: Deixava.

PERGUNTA: Mas já cortada ou sem estar cortada?

Dona Saturnina: Cortada.

Senhor Rubens: Cortada, agente fazia balsa e levava. Levava la no porto.

Dona Saturnina: Quantas barcadas de caxeta nos levaram.

Senhor Rubens: Eu levava com ela.

Dona Saturnina: Cortava caxeta ali e levava, puxava cipó e fazia aquela balsa grande ai nos pegava e levava lá.Descia rio abaixo. 
PERGUNTA: Então cortava caxeta deixava no rio pra fazer barco?

Dona Saturnina: Isso.Ai levava a canoa amarrada assim atrás.Um dia nos fomos e eu falei assim pra ele, ele ia na frente ...

PERGUNTA: Soltou a canoa?

Dona Saturnina: A canoa saiu. E eu falei pra ele a canoa saiu.Ele pego e falo pra ir pega de volta lá no fundão e saiu ...

PERGUNTA: Teve que dar a volta e pegar a canoa

Dona Saturnina: Mas eu quase me matei de dar risada ele caiu no fundo, o chapéu dele boiando.

PERGUNTA: Ai ele pulou na água?

Dona Saturnina: Pra pegar a canoa que tinha saído de uma vez, ai eu fiquei nessa balsa.E agora o que vai fazer? Agora não tem jeito .Parava no postão até a maré puxar pra lá, né .Ai então nós pegávamos e ia lá no porto.No porto do Boafica onde tem um barco.

Lá nós carregávamos tudo em cima do barranco, deixava tudo lá pra depois no outro dia carrega.

PERGUNTA: As caxetas?

Dona Saturnina: As caxetas. I meu filho ...

PERGUNTA: Sabe que agente achou um monte de madeira no meio do mangue atolado né?

Dona Saturnina: Mas caxeta é outro tipo, que apodreceu, né ?

Luis: Mas essa é madeira de leite. Papai fala que é do dilúvio que teve no Mandira.

PERGUNTA: Essa daí não é caxeta?

Luis: Não, não a caxeta se desmancha.

Dona Saturnina: A caxeta desmancha.

Luis: A caxeta é usada para fazer tamanco, usava antigamente pra fazer papel, lápis.

Senhor Rubens: A caxeta é muito boa para fazer lápis.

PERGUNTA: Então não da para fazer barco?

Dona Saturnina: Não

Senhor Rubens: Pra tamanco, violão, instrumento leve, porque é uma madeira leve .Pra mecânico, tudo isso ai.Muito rentável, muito caro.

PERGUNTA: Ai se levava até o porto ali de Boacica porque já ficava perto da estrada?

Dona Saturnina: É.Por que por aqui não saia, por que na beira do rio que cortava. Então quem que cortava que o carro passava. Puxava por aqui , puxava daí do brejo. E o que agente portava lá na beira do rio portava por aqui.

PERGUNTA: Dona Saturnina a senhora não sabe quem era? Porque dizem que a terra... seu Chico conta que a terra dos Mandira era doação, foi da relação do senhor, Seu Andrade com uma das suas escravas, que gerou filho Francisco. A senhora não ouviu fala o nome dessa escrava, a mãe do seu Francisco? Será que a senhora lembra o nome dela? 
Dona Saturnina: Eu não sei .

PERGUNTA: Uns dizem que é dona Tereza, outros dizem outros nomes?

Dona Saturnina: Eu sei que ele era da família de irmã de papai, não sei .Tinha Gertrudes, Flora, Leocádia, Tereza, parece que tinha Liturgina e parece que depois tinha arrumado uma filha dele com Liturgina.

PERGUNTA: Mas essa é todas suas tias?

Dona Saturnina: É. Tias da família de papai , do avô.

PERGUNTA: Ah, são suas tias avós? Tias do seu pai?

Dona Saturnina: É.O pai do finado Antônio Mandira que morava lá , eu não me lembro do pai dele, mas eu sei que a mãe dele, era eu não sei, agora eu não me lembro...

Senhor Rubens: Acho q o pai do Antônio Mandira era Chico não é?

Dona Saturnina: Não. Eu vou quase me lembro do nome dele mas na hora eu não lembro eu sei que a mãe dele era a Leocádia, por que quando a cobra mordeu ela, foi chamado ele .E ele falou que ele não vinha, não vinha ainda por que não podia. Quando inteirou quatro dias ou coisa assim ele veio, ai ela começou a ficar ruim, ficar ruim. Aí foram chamar, encontrar com ele no meio do caminho. Falaram pra ele que se ele não chegasse por que ela estava muito ruim. Ele falou nem que fosse ou vivo ou morto ele via ela. E ele chegou, quando ele chegou nela ele...

PERGUNTA: Ele quem? O seu João?

Dona Saturnina: O Antônio Mandira.

PERGUNTA: O seu Antônio Mandira?

Dona Saturnina: É. Aí ela falou: "É meu filho você veio me mata." Ai ele falo: "Não faz mal, nem que a senhora morra, mas eu tenho que ver a senhora." Ai ele falou com ela e ela morreu.

Por que naquela época a cobra mordia e tinha gente que fazia mal mesmo. E a cobra mordeu ela e ele chegou nela e fez mal pra ela demais da conta e ela faleceu.

Então ela que eu to te dizendo que era a Flora .

PERGUNTA: A Flora o nome dela.

Senhor Rubens: Essa aí é a mãe dele.

Dona Saturnina: A mãe dele .Ai a mim to esquecida.

PERGUNTA: O nome da mãe do seu Antônio era Flora?

Dona Saturnina: É isso aí .

PERGUNTA: E seu João?

Dona Saturnina: Agora não sei qual era. Não lembro qual era .

PERGUNTA: E o pai do seu João era seu Francisco e do seu Antônio era outro?

Dona Saturnina: Também não lembro. Eu acho de vovô era um. Era o irmão do pai de Antônio, me parece que eles eram primos. Agora não sei se o pai dele era irmão da mãe dele. Por que diziam que era um casal, não posso dizer também uma coisa que eu não sei, não tenho certeza. 
PERGUNTA: Se eram primos de mãe e pai.

Senhor Rubens: Por que eu acho que o velho, o Mandira, o filho, parece que , não sei bem , mas parece que era filho do Andrade com uma mulher, empregada dele.Então ele pra não deixar o filho sem ter herança assinou como ...

Dona Saturnina: Mandira. Ele passou a herança dele para os dois filhos. Os dois filhos, um filho e uma filha, sabem lá. Ele passou a herança para os dois filhos e ficou Mandira. Eu sei que tinha o finado Deco. Que também era da mesma família.

PERGUNTA: Tinha gente na verdade.

Senhor Rubens: Era uma família grande.

PERGUNTA: O que mais que a senhora lembra dessa época ai Dona Saturnina? Das histórias ai que contam. Tinha a história da mulher que não pisava no chão, tinha que colocar em cima da carroça... O senhor disse que moravam dentro da casa de pedra?

Dona Saturnina: Dentro da casa de pedra. Porque foi desmontado um pouco. Porque a turma desmontou pra ver ouro, ai descontou. Era tudo cheio de quarto.Tinha a sala grande, tinha um quarto pra cá, o quarto pra lá, outro pra cá, era tudo cheio de quarto. Onde eles moravam .

PERGUNTA: E tinham outras casas também feitas de pedra.

Dona Saturnina: É.

Senhor Rubens: É por que no Mandira tinha aquela de pedra do PC, do finado Chiquinho, que morava ali, que fazia baile nele. Ali bem no Sambaqui.

PERGUNTA: Mas a parede era feitas de pedra também?

Dona Saturnina: Era. Até na casa de Chiquinho tinha um murão assim. Que ia até lá embaixo.

Senhor Rubens: Por que ali na estrada fizeram bem murando a casa assim. Ai os padres, os padres lá de São Paulo, o chefe lá dos padres, veio ai uma vez, olhou o lugar lá da estrada e ai achou ruim. "Não, não, não, aqui no Sambaqui não toca."

Ai a firma mudou, fez uma curva. No Sambaqui pra cá, ali na onde você vai. Ai era muito ruim a estrada lá pra dentro, era bastante gente, ai o encarregado falou: "Tira essa pedra desse Sambaqui, toquem o enxadão a picareta e catem essa pedra pra nós levarmos para aterrar a estrada." Metemos a enxada eu, o Bernardo, o Eliseu Martin era uma turma.

Rapaz do céu! Cavocamos acho que meio metro. Tinha tanto osso de gente. Cabeça de osso de gente perfeita. As canelas, esta mão assim, fizemos um monte, um monte de osso. O que vamos fazer com aquilo? Ai chamamos o Rui que era o encarregado. "Seu Rui olha o que o senhor mandou fazer pra tirar a pedra, tu veja ai!" "Ai rapaz é o que isso aqui?."

\section{PERGUNTA: Debaixo das pedras?}

Senhor Rubens: Encostando debaixo da pedra, tudo assim.Aquele monte.

Mas será que era gente que morava aqui ?ha eu não sei essas coisas de escravo quem sabe eles não matavam e enterravam aqui.Ai o que eles fizeram, pegaram esse monte de osso, vieram os homens de São Paulo pegaram um pouco desses ossos e o resto deixaram lá.Mas um monte de osso .Mas negócio de osso eu não entendo nada. 
Luis: A estrada pega em cima do Sambaqui né?

Senhor Rubens: É ai teve que mudar toda essa estrada por fora.Ai o que eles inventaram la . vamos plantar um pouco de coco.Por que a idéia deles não era eles plantarem coco.Vinham caminhões e caminhões plantar lá .Meteram a máquina lá no pedaço, que faz coco nada.A idéia deles quando compraram a terra era para botar o Sambaqui, pra tirar o Sambaqui que era minério, adubo.A idéia era essa, mas não deixaram.

PERGUNTA: Mas só tem um Sambaqui ali ou tem mais?

Senhor Rubens: I, quer ver Sambaqui passa pra o lado e lá.Onde Julho mora lá, lá que tem Sambaqui.Tem Sambaqui pra mais de três metros de altura.Lá em cima lá mesmo tem um que é muito gigante .

PERGUNTA: Mas isso já é pra lá.

Dona Saturnina: É pra lá .No Mandira que nós sabemos é aquele ali, só né .Só aquele só.

PERGUNTA: Mas as casas todas eram de pedra antigamente?

Dona Saturnina: Não, a casa antiga mesmo era de pedra .Só que da gente quando agente morava era de vara, de barreado.

PERGUNTA: barreado? Mas ai colocava pedra em baixo, ou não?

Dona Saturnina: Não esteio.

PERGUNTA: Era só madeira?

Dona Saturnina: Só madeira só.

PERGUNTA: E pra fazer as roças que ficavam do lado da casa?

Dona Saturnina: Aí roçava e derrubava .

PERGUNTA: Roçava ou colocava fogo?

Dona Saturnina: Depois que derrubava, roçava.Derrubava ai colocava fogo.

PERGUNTA: Daí não tinha problema de vir pra casa?

Dona Saturnina: Não.Por que aqui no nosso lugar você pode por fogo.Nós queimamos tudo esse mato por ai , tudo foi queimado.Mas é só onde agente queima.Onde está roçado, derrubado, ele queimou aquele lugar não pega fogo no mato.Igual agente assiste na televisão, não sei quanto queimando tudo no mundo de Deus.Aqui não.

Senhor Rubens: A terra é muito molhada.

Dona Saturnina: Pega igual na no bananal .Nós roçamos pra plantar milho e tinha outro pedaço de bananal ai nós pegamos e ratemos, pegamos com o balde e jogamos um pouco de água.O fogo chegou e acabou fogo tudo aqui.

PERGUNTA: E plantava o que dona Saturnina?

Dona Saturnina: Planava assim no chão unido , arroz.E chão mais seco é milho, feijão.E mais perto do morro.

PERGUNTA: Mais perto do Morro da Mina?

Dona Saturnina: É.

PERGUNTA: Agora plantava tudo, você falou plantava também café? 
Dona Saturnina: É café também.

PERGUNTA: Arroz, café, feijão, milho.

Senhor Rubens: Não comprava café , não comprava arroz , não comprava feijão, galinha essas coisas assim de fartura, porco.

Dona Saturnina: Nós temos cafeeiro ainda .Não torro café por que não temos forno de lenha aqui.Mas Neuza quando está na casa dela ela torra, nós temos um saco cheio assim até a boca de café.

Luis: Ele faziam o melado também.

Dona Saturnina: É fazia melado .Mas um tempo desses pra cá que nós paramos, por que eu não pude mais e ele tampem não pode, paramos de fazer melado.

Senhor Rubens: Fui operado aqui no peito do coração então não dá pra fazer essas coisas.

PERGUNTA: Muita fumaça, né?

Dona Saturnina: É, mas quando nós podíamos, nós fazíamos melado e temperava as coisas só com melado.fazia pegar esses garrafões assim, cinco seis garrafões só de melado.

PERGUNTA: Melado é bom né?.

Dona Saturnina: I meu senhor, nem me fale, coisa gostosa melado.

\section{Fita 3:}

Dona Saturnina: A única coisa que agente vendia era o arroz.

PERGUNTA: E como é que levava pra cidade o arroz?

Dona Saturnina: De canoa.

PERGUNTA: Levava de canoa?

Dona Saturnina: É.

PERGUNTA: Levava o remo?

Dona Saturnina: O remo é.

PERGUNTA: Tinha aqui também canoa a vela ou não?

Dona Saturnina: Tinha canoa a vela. Agente levava mais remando.

PERGUNTA: E como era feita a canoa a vela?

Senhor Rubens: Era feito de pano, e algodão.

PERGUNTA: Pano de algodão?

Senhor Rubens: Pano branco que agente colocava na canoa quando o vento tava forte. E ia de vela.

PERGUNTA: Ia até onde?

Dona Saturnina: Caratuva.

PERGUNTA: Caratuva é aonde?

Senhor Rubens: É ali onde sai à barra do rio da Mina. 
PERGUNTA: Ah ta do rio.

Senhor Rubens: Rio dos Imarés.

PERGUNTA: E as canoas faziam aqui também?

Dona Saturnina: É.

PERGUNTA: E como que faziam?

Dona Saturnina: Meu irmão que gostava e fazer canoa, vô ele. O Florindo.

PERGUNTA: O Florindo?

Dona Saturnina: Ele que gostava de fazer canoa, nossa! Uma vez ele fez uma pra nós e nós compramos a canoa dele pequenininha. louca que era um castigo.Nós íamos daqui para Cananéia, levava Reinaldo pequenininho dentro da canoa..

PERGUNTA: E ia remando. E ia todo mundo a família toda?

Dona Saturnina: Ia eu, Rubens e o Reinaldo que era o pequeno. Ai nós pegávamos na canoa e forrava o fundo da canoa bem forrado com pausinho assim, e arrumava um colchão, cochãosinho e forrava assim. Arrumava Reinaldo dentro da canoa, cobria ele por cima, fazia igual um arco assim e cobria ele por cima ai Rubens remava um pouco e eu remava um pouco.E eu remava, atravessava o mar.

PERGUNTA: Tudo no remo, né?

Dona Saturnina: Tudo no remo.

PERGUNTA: E o seu Florindo fazia aquelas canoas de uma madeira só?

Dona Saturnina: É de uma madeira só.

PERGUNTA: E como que era pra fazer essa canoa?

Dona Saturnina: Era cortado primeiro com machado, depois cavoucado com machado e depois limpa ela e passava o cipinho. Eu nem sei que fim deram naquele formosinho de coisa, enchadinha de uma mão só de compadre Florindo tinha uma de uma mão só que ele limpava assim a canoa .

Nós temos ainda uma canoa, nós temos três canos no porto.

PERGUNTA: Ah é? Mas de uma madeira só?

Dona Saturnina: É.

PERGUNTA: Essas canoas antigas?

Dona Saturnina: É. Nós temos três canoas, nós temos uma grandona que Durval emprestou pra levar lá em cima e furou .

PERGUNTA: E como que era navegar ai no meio desse mar de dentro, era difícil ou fácil de navegar de canoa?

Dona Saturnina: Era difícil. Quando o vento estava bom gente andava bem mas quando caia o vento agente tinha que parar por que senão não ia .

PERGUNTA: Então era a vela mesmo?

Dona Saturnina: É a vela.

PERGUNTA: Tudo a vela. 
Dona Saturnina: Não depois de uma contingente não foi mais a vela, foi a remo mesmo.

PERGUNTA: Mas é fácil andar a vela? Como que é?

Senhor Rubens: É fácil. A canoa é baqueada, o ultimo banco da frente, da proa ela tem um buraquinho assim no banco. Para colocar bem ali o mastro. O banco segura a vela. Então, tem uma corda que agente puxa ela pra cima, ai ela vai pra cima. Aí tem uma varinha assim, um pau lá na ponta do canto, aí lá tem uma corda. Aí quem senta lá na ponta. Ai caço o vento e vamos embora.

PERGUNTA: Ai só segurando a vela?

Dona Saturnina: É. Segura na corda.

Senhor Rubens: Ai eu remo na água pra segura a canoa e vai embora.

PERGUNTA: Tem ainda essa canoa a vela lá?

Senhor Rubens: Eu mesmo não uso mais. Só uso a cano com o remo.

PERGUNTA: Mas dizem que é muito difícil navegar ai no Mas de Dentro.

Dona Saturnina: É difícil sim.

Senhor Rubens: Tinha que carregar toda a canoa com carga e chegava lá na prancha e lá em Cananéia arrumava uma carroça. Aquele tempo tinha carroça com cavalo, agora diz que não pode usar mais .Ai chegava ali carregava a carroça e ia e ia lá pro negociante e vendia lá pro negociante.Lá tinha também engenho, em Cananéia.

PERGUNTA: Mas parava onde lá a canoa?

Senhor Rubens: Parava na prancha, pra baixo da prancha tinha bastante porto. O porto dali da virada do mar tinha caminho que chegava em Cananéia.

PERGUNTA: A prancha que você diz é ali na beira mar?

Dona Saturnina: A prancha é ali onde é o ferrebote.Sabe o ferrebota ali na balsa ? Agora virou balsa, mas antes era prancha .E paravam ali e quando nós íamos de canoa nós íamos por cá e parava no porto de Tio Domingos, do meu tio.Irmão de mamãe.

PERGUNTA: Mas o ferrobote que vocês estão falando é do continente ali ou de porto Cubatão?

Dona Saturnina: O de Porto Cubatão.

PERGUNTA: Ah ta. Aquela é a prancha?

Dona Saturnina: É.

Senhor Rubens: Pra baixo do Porto de Cubatão, bem ali na ilha de Cananéia, na parte que vai pra baixo .É cheio de porto ali...Ali tinha um caminho de morador e ia pra Cananéia.

PERGUNTA: Que é o caminho que fazem hoje?

Dona Saturnina: Isso.

Senhor Rubens: -Não tem co cemitério ali de Cananéia, então ali desce aquela rua ali e tinha caminho que vinha embora .

PERGUNTA: E quando o pessoal falecia enterrava lá ou enterrava por aqui?

Senhor Rubens: Leva lá. 
PERGUNTA: E levava tudo na canoa?

Dona Saturnina: Tudo na canoa .

PERGUNTA: E como era a cerimônia? Tinha cerimônia?

Dona Saturnina: Tinha a cerimônia em casa.Ai ia uma pessoa adiante na canoa, fala com o padre, arrumava uma casa ai do pessoal levava o defunto era carregado na esteira, levado na esteira.Ai ia na canoa .

PERGUNTA: Esteira de piri?

Dona Saturnina: Na esteira de piri.Ai levava e chegava lá no porto ai arrumava como se carrega num pano, ai duas pessoas atrás e duas na frente. E iam carregando. Quando um cansava o outro pegava. Até chegar na igreja. Então lá da igreja ...

PERGUNTA: E carregava na esteira?

Dona Saturnina: Na esteira .O caixão dentro da esteira, quando tinha caixão.E quando não tinha caixão feito compra em Cananéia. Levava o defunto na esteira.

Levavam, quando chegavam lá na igreja o padre rezava, então lá arrumava o caixão. Ai de lá que levavam para o cemitério.

Era difícil. Não é igual agora que a pessoa morre e vai na mordomia (risos).

PERGUNTA: E igreja tinha ou não?

Dona Saturnina: Aqui pro sítio não.

PERGUNTA: E com o que faziam as cerimônias? Se tinha um casamento essas coisas?

Dona Saturnina: Só em Cananéia.

PERGUNTA: Tinha que ir pra Cananéia pra casar?

Dona Saturnina: Tinha .Casamos em Cananéia .

PERGUNTA: Vocês casaram em Cananéia?

Dona Saturnina: Em Cananéia, é.

PERGUNTA: Vocês casaram na igreja?

Senhor Rubens: Casamos primeiro no civil e depois na igreja.

Dona Saturnina: Em Cananéia.

PERGUNTA: Mas o pessoal casa na igreja?

Dona Saturnina: Casa .Preparação e casa na igreja .Agora tem a preparação pra casar na igreja. $\mathrm{Na}$ época em que nós casamos não fazia isso.

Quando agente ia casar falava com o padre, ai ia lá e casava na igreja.

PERGUNTA: Ai levavam todos os convidados pra lá e ia todo mundo?

Dona Saturnina: Isso.

PERGUNTA: Pai, mãe e ia todo mundo prá lá?

Dona Saturnina: É.

PERGUNTA: E ai de barco todo mundo pra lá?

Dona Saturnina: É.E aqui faz a primeira comunhão também, e batizado só. 
PERGUNTA: Então naquela época não tinha, mas se tinha celebração era como?

Dona Saturnina: Aqui pro sítio não tinha. A primeira vez que apareceu a celebração aqui foi quando o finado Jango morava naquela casa ali pra cima de pedra que veio um padre do Paraná , ai que foi feita uma missa na casa do finado Jango.Ficou doze dias ai.

PERGUNTA: O finado Jango é o mesmo Vicente?

Dona Saturnina: É finado Jando é o mesmo Vicente que é meu tio e não meu avô.

PERGUNTA: Ah ta, seu tio.

Dona Saturnina: Ai ficou esse padre lá, que começou a rezar e assistimos missa ai , depois de muito tempo que apareceu o Padre João.Ai que foi feita a capelinha.

Primeiro rezava a missa na escola, depois que começou a estradinha.Então rezava a missa na escola do Mandira.

Depois que foi feita a igreja.Era pra fazer aqui na escola que ficava no meio.

PERGUNTA: E as imagens todas que ficavam na igreja?

Dona Saturnina: Esse era do meu avô

PERGUNTA: Do seu avô João?

Dona Saturnina: Do avô João.Do avô João Vicente, que ficou pra Francisco e o oratório ficou na casa de Justino, depois de Tio Chiquinho passou para casa de Jando , e depois da casa de Jando passou pra igreja.

PERGUNTA: Quando construíram a igreja o Jando ainda era vivo?

Dona Saturnina: Era vivo. Não já tinha falecido.O oratório ficou da casa de Jando pra casa de Cristino e da casa de Cristino que foi levado pra igreja.

PERGUNTA: E faziam o terço nessa época ou não?

Dona Saturnina: O terço fazia, só que o terço era assim, na casa das pessoas. Tinha casa própria para fazer. Tinha casa do finado Jando.Primeiro era na casa do Chiquinho e depois que o finado Jando começou a mandar mais no sítio, nas coisas, ai passou pro finado Jando.Ai o terço era na casa dele.

PERGUNTA: Eu fico pensando eles não roçavam antigamente porque eles roçavam com o que antigamente? O que eles usavam para roçar?

Dona Saturnina: Era com a foice.

PERGUNTA: Mas já tinham a foice, já foram buscar em Cananéia a foice trazer, imagina pra ir buscar em Cananéia a foice.

Dona Saturnina: Foice, machado tudo comprado em Cananéia.Tinha o finado Lico , o tio de Catarina é que fazia a foice.

PERGUNTA: Ele fazia?

Dona Saturnina: Ele fazia a foice, uma foice boa que ele fazia.

PERGUNTA: E como ele fazia?

Dona Saturnina: Olha eu não sei como é que ele fazia.

PERGUNTA: Mas ele comprava já ferro?

Dona Saturnina: Eu acho que ele comprava, 
Senhor Rubens: Mola, e ele fazia o carvão.Eu o viaele fazer . Ele esquentava aquele ferro bem quente, cortava no tamanho da foice daí começava a bater.Batia até deixar o tipo da foice. Pegava aquela forma pegava certinho e depois batia e depois arrumava o aço .

PERGUNTA: Depois alisava?

Dona Saturnina: É. Ele que fazia a foice, finado Lico .

PERGUNTA: Finado Lico?

Dona Saturnina: Lico , é irmão de Dona Zélia ali .Tio de Catarina .

PERGUNTA: Pra se comunicar com o povo lá de Pindaúva só pela trilha?

Dona Saturnina: É só pela trilha.

PERGUNTA: E ia vender coisa de lá e trazia coisa de lá?

Dona Saturnina: É trazia de lá.

PERGUNTA: O que ia vender lá? Peixe o que mais?

Dona Saturnina: Ele levava peixe e vendiam lá e comparavam farinha .

PERGUNTA: De lá?

Dona Saturnina: É de lá .

PERGUNTA: Plantava mandioca aqui também?

Dona Saturnina: Nós plantávamos. Plantava bastante, nossa compadre Firmino plantava bastante.

PERGUNTA: Então o pessoal usava cavalo aqui?

Dona Saturnina: Usava.

PERGUNTA: No Mandira também?

Dona Saturnina: No Mandira quem tinha cavalo era só o finado Cristino.

PERGUNTA: Agora o que o pessoal contava assim, vocês falavam do Sambaqui? O que era o Sambaqui? Vocês sabem o que era? O que o pessoal falava?

Senhor Rubens: Olha desse ai a mim não sei. O pessoal antigo sabia, mas era difícil falar pra gente. Muita coisa eles não falavam. A mesma coisa uma reza, uma coisa qualquer era difícil de ensinar. Por que minha mãe sabia uma reza. Antes de sair, acordava e a primeira coisa que ela fazia era rezar aquilo ali, pra depois sair para ao serviço. Pra se defender da cobra. E ela não ensinava nós. E não ensinou. Morreu e não ensinou. Por que se a pessoa aprende aquela oração ali e um dia não reze. Pode contar que se a cobra morder, pronto.

Dona Saturnina: Teve uma vez que falaram que o Sambaqui foi da época do dilúvio.

PERGUNTA: Os mais velhos falava?

Dona Saturnina: É, os mais velhos falavam que o sambaqui foi da época do dilúvio.

PERGUNTA: Mas já sabiam que ali era o Sambaqui?

Dona Saturnina: É, depois que deu o dilúvio que virou o Sambaqui. Por que aqui, por que não existia berbigão. Por que aquilo ali é um berbigãosinho. Pode ver que é daquele berbigãosinho que tem lá fora no mar. 
PERGUNTA: Aqui no mar de dentro não tem isso?

Dona Saturnina: Não. Da onde que veio aquilo? Então aquele ali foi da época do dilúvio que veio de lá do dilúvio então foi de onde ficou esse monte que viro o morro de Sambaqui. Igual esses paus que vocês acham lá fora, tudo isso é madeira.

Senhor Rubens: Ai mesmo no porto do Mandira, onde deixa a canoa .

PERGUNTA: Agora o pessoal gostava de fazer casa em cima do Sambaqui.

Dona Saturnina: É.

PERGUNTA: Por causa de que?

Dona Saturnina: Não sei. Por que aqui no nosso sítio também tem um Sambaqui. E o finado Jocimim, é onde ele morava. O tio dele. Em cima do Sambaqui. E quando ele morreu, o filho dele que morreu no porto também a casa dele é em cima do Sambaqui.

PERGUNTA: E porque o povo gosta de fazer casa em cima do Sambaqui?

Dona Saturnina: Não sei.

Senhor Rubens: Por que o lugar ali é baixo, o terreno é baixo, não é enxuto. Então o mais enxuto era ali. Os morros bonitos até. Então a pastagem do gado era pra cima com grama ...

PERGUNTA: Mas sabem que aquilo é o Sambaqui?

Dona Saturnina: Sabem.

PERGUNTA: Fazem a casa em cima do Sambaqui.

Senhor Rubens: Agora eu não acredito nisso ai. Eu acredito que aqui ali foi um rio que cobriu aquilo ali. O pessoal do Mandira trabalha com ostra, aonde eles jogam aquela casca da ostra vive um monte de... Então pra mim eu não credito naquilo ali. Aqui tem um ali no meio do pasto... pra lá um pouco.

PERGUNTA: Tem um o que? Um Sambaqui?

Dona Saturnina: Tem um sambaqui também.

PERGUNTA: Ahé? Um monte de ostras? Eu precisava ver este Sambaqui.

Senhor Rubens: Eu plantei nele uma roça de mandioca.

Dona Saturnina: Deu mandioca que só vendo.

PERGUNTA: Mas deu mandioca? É bom pra plantar no sambaqui?

Dona Saturnina: Uh, meu Senhor.

Senhor Rubens: Ali na casa de pedra também. Agente ia fazer a fogueira, uh! Correce de pé! Saia cada tiro de fuziu... era bala... que tinha que sair de perto. Quantas vezes agente já não correu de lá, quando ia fazer a roça.

Depois na vala solta eu e meu finado irmão, Florindo, nós estávamos cavando... que ele me ajudava... topei um negócio assim (mostra o tamanho com a mão) alto, como um monte de barro, como se fosse uma cova de cemitério mesmo (risadas)... ai finado Floriano era muito moleque e já meteu a enxada assim... não tinha um palmo assim... já via a cabeça... o cabelo assim... fino... bem amarelinho... tudo embuguilhado assim...

PERGUNTA: Vocês chegaram a ver isso ai?

Senhor Rubens: É! Foi. To falando pra você! Plantei até Ligia lá. 
Dona Saturnina: Faça uma cova bem grande ai... tudo que você plantar nasce.

PERGUNTA: Mas chegou a ter combate ai?

Senhor Rubens: Chegou sim.

Dona Saturnina: Uma vez tinha uma cova bem grande assim... eu plantei rama em cima. Nossa! O que deu de mandioca... (risos)

Senhor Rubens: Esse negócio de bala ai... quantas eu não topei por ai!? Pente de bala. Eu fiz uma valeta ali e topei um pente de bala.

PERGUNTA: Quando o Sr. achar de novo esse material por ai, o Sr. guarda pra eu tirar foto dele.

Senhor Rubens: Pode deixar.

Luis: Lá em Pindauva, essa semana, o Valdir tava contando lá que o rapaz tinha achado lá. Ele tava caçando lá e achou. Filho do Seu Bernardo.

Dona Saturnina: Bernardo Borges.

Luis: Isso. Disse que achou uma espada. Ele guardou lá. Trouxe pra casa e guardou.

PERGUNTA: O pessoal tem muito material. Pois bem. Tem muita história né, Dona Saturnina? Na verdade eu tinha que vir mais cedo pra conversar mais.

Luis: É... vamos embora antes que a chuva caia. 


\section{Entrevista com Seu Arnaldo Mandira}

Eu tava falando sobre meu nascimento. Então, eu nasci no Mandira no ano de 1932, no tempo da revolução. E meu pai, Geraldo Mandira correu de lá do Mandia lá para o sítio de meu avô na beira mar, lá pra Itaquari. Então eu nasci lá pra Itaquari. Ai depois da revolução ai ele veio...

PERGUNTA: Dizem que teve um pessoal que durante a revolução saiu lá da casa-depedra e foi lá pras Areias.

Isso, um pouco deles, como meu avô, ficaram nas Areias, que é o mesmo que Mandira. Mas meu pai, como minha mãe, Maria Izídia Mandira estava grávida, ele foi mais longe e foi pra Itapitangui no sítio do sogro dele, meu avô, Joaquim Mateus.

Ai, depois da revolução, nos retornamos pro Mandira outra vez. Fomos morar perto da casa-de-pedra, onde eu cresci.

Depois quando eu tinha doze anos eu fui pra Iguape com meu tio, Amâncio Mandira. Frequentei dois anos o grupo escolar Martim Afonso. Depois meu irmãoque morava em Iguape foi trabalhar nas docas de Santos e eu voltei pros Mandira outra vez. Então fiquei com meus pais trabalhando. E desde este tempo já existia o terço cantado. Quando agente é novo não dá muita atenção pra essas coisas, mas eu sempre me dedicava a ajudar a rezar, escutava, né?...

Nasceu em Itaquari, em 1932. Por causa da revolução seu pai, Geraldo Mandira (filho de João Vicente Mandira), se mudou para Itaquari com sua mãe, Maria Ezidia Mandira, filha de Joaquim Mateus (família de Itaquari).

Outros parentes foram morar nas Areias.

Quando retornou foi morar perto da casa de pedra.

Desde o tempo de meu avô já existia o terço. João Vicente Mandira já rezava o terço cantado.

Eu sempre acompanhava o terço. Meu avô que rezava, João Vicente (pai do Jango). Eu conheci muito pouco meu avô, mas não estou muito lembrado como era o movimento do terço. Sei muito bem por que minha mãe contava.

Nesse tempo era uma coisa muito caprichada, com muito respeito. Eles tinham muito amor, muita fé pelo trabalho que faziam. Principalmente na festa de Santo Antônio, que é o padroeiro do Mandira. Todo ano existia, como existe até hoje o terço de Santo Antônio, como fazemos.

Ai foi passando, passando... ai depois João Vicente veio a morrer. Demorou um pouco o terço ficou meio descontrolado. Até que meu tio deu continuidade no terço. Ai, ficamos sempre rezando junto no Santo Antônio e na Quaresma principalmente. Nesse tempo da quaresma agente tinha de penitência todos os dias santos da quaresma agente rezava. Tinha também as rezas em casa que os vizinhos pediam. Mas o certo mesmo era quartafeira de cinzas, depois sexta-feira dos passos, sexta-feira das dores e na semana santa, começava de quarta-feira de trégua até sexta-feira da paixão. Esses dias agente sempre rezava, juntava muita gente... Depois meu tio Jango, que trabalhava com o espiritismo, ele curava. Então na sexta-feira da paixão ele benzia as pessoas, benzia as águas com a fé. Isso era de penitência todo ano tinha que ser feito. 
O terço no Mandira acontece principalmente, todo dia 12 de julho, na véspera de santo Antônio, que é dia 13. Depois do terço, pra não passar a noite acordado, agente fazia o fandango. Depois do terço tinha fandango.

Ai no final da festa, no outro dia, seis horas da manhã rezava de novo. Ficava a noite inteira acordada, quando eram umas seis horas soltava foguete para avisar o pessoal que estava dormindo, se juntava todo mundo novamente e tornava a rezar. Depois fazia a despedida e cada qual ia buscar seu descanço.

O problema é que começou a juntar um pessoal que começava a bagunçar a noite, sabe? Briga, confusão, traziam muita bebida no baile. Depois de um tempo em diante foi entrando questões, entrando briga, tinha vezes que dava confusão grande, pancadaria, teve vezes que quase chegou a ocorrer desastre de morte. Então meu tio Jango, pra evitar essas coisas, parou com o fandango no tempo das festas. Ele não dava mais ordem pra fazer o fandango. E nesse tempo o pessoal era muito unido e sempre aceitava o que ele determinava. Então parou o fandango, não fizemos mais fandango.

Agora de uns tempos pra cá mudou o tipo de festa. Hoje no Mandira diferenciou muito o tipo de trabalho, de festa que fazem por lá. Então eles estão continuando do jeito que fazem agora. E graças a Deus que de um tempo pra cá o pessoal adquiriu mais um conhecimento, mais um respeito por essas coisas. Então quem trabalha com o terço tudo bem e quem não trabalha, mas participa com muito respeito, um respeitando o outro, a família. Por que o que acontece é que muitas das pessoas que faziam confusão naquela época, hoje acabou se casando e tendo filhos e sobrinhos que já estão na família Mandira, também. Então foi onde se encontrou aquela união que hoje mais ninguém tem aquele problema.

E o terço, depois de meu avô ficou com Jango, que passou a rezar. Depois que Jango faleceu ficou pro meu primo Cristino. Ele era um homem muito consciente das coisas, tinha uma ideia muito boa, entendia muito bem as coisas, uma pessoa de muita paciência, muito católico, deu continuidade no terço até o final da vida dele.

Eu não tenho tanta experiência como ele, mas toda vida eu tinha vontade de aprender e ajudava muito ele na reza. Sempre era eu e ele. Quando tinha um terço nas casas ele me avisava e eu ajudava ele. Então quando ele faleceu eu dei continuidade no terço. Então hoje eu dirijo o terço lá. Mas o pessoal de lá, que estão lá agora, como Chiquinho, o primeiro terço que ele rezou foi esse agora do mês de julho de Santo Antônio. Mas só que eles sozinho ainda não tem muito a experiência, né? Principalmente no começo do terço.

Quanto ao CD do terço, o que eu tava falando pro senhor é o seguinte: eu gostei muito do que eles fizeram, só não ficou muito certo pra mim a sequência que fizeram da oração com as imagens que colocaram. Ficou uma coisa meio embaralhada. (...) Eu gostaria que quando começasse os cânticos fosse até o fim, pra ficar documentado da forma correta.

PERGUNTAS: O que eu acho interessante é que o calendário do terço segue as datas religiosas da igreja católica, Né? Agora quando Seu Jango, que era espírita fazia o terço tinha alguma diferença? Como era?

A diferença que tinha era só o modo da arrumação. Por que naquela época o terço acontecia nas casas das pessoas, não tinha igreja. Então as salas eram arrumadas com as esteiras de Peri, forravam com as toalhas e os travesseiros pras pessoas ajoelharem. Por que na hora de ajoelhar naquele tempo era mais caprichado que agora, sabe? Conforme as orações que faziam a pessoa rezava ajoelhada. Mas os tipos das orações, as rezas dos 
terços eram a mesma que de hoje. As músicas nunca mudaram, são as mesmas músicas desde a época do meu avô.

\section{PERGUNTA: E seu avô aprendeu com quem?}

Ele aprendeu com o pai dele, o avô dele. Isso eu não sei. Eu penso que isso vem desde o começo, né? Do nascimento do pai dele, do avô e do bisavo, né? Eu comparo o terço com o começo da missa. Por que agente não sabe explicar como foi começado a missa, quem começou ou por que começou. E o terço do mesmo modo. Por que quem morava no sítio não podia ir sempre pra missa na cidade e o padre não ia para o sítio, mas já existia a cultura da procissão daquele trabalho. E assim veio encaixando.

Só que o terço e as orações é assim por que não veio mudado. Não teve mais pessoas pra fazer outras orações. Por que na missa, isso eu acompanho por que sou dirigente de culto aqui na igreja, cada ano vem um pouco de cântico, já tem as pessoas que entendem, que sabem, que conhecem então cada ano eles fazem outros tipos de cântico. Inclusive, muitas pessoas não dão valor para a oração do terço. Por que é sempre o mesmo cântico, só aquele, só aquele, só aquele.

PERGUNTA: Mas na igreja não tem o terço cantado. É uma manifestação católica, mas que na igreja não tem.

Não, na igreja não tem. Eu não sei por que os padres não se preocupam em aceitar essas coisas. Não sei se é por que não acreditam ou acham que não tem valor, mas a igreja não aceita. Eu já fui rezar um terço em Iguape, dia 04 de agosto, mas não foi na igreja. Era um festival que tinha e nos fomos convidados pra rezar o terço. E fui rezar também aqui em Cananéia, aqui na igreja São João Batista, na vinda de Nossa Senhora, que veio fazer visita em Cananéia e o padre nos convocou. Nessa ocasião eu gostei por que meu primo Cristino falava que João Vicente Mandira tinha feito uma promessa de rezar o terço na igreja de São João Batista. Mas nunca essa promessa foi cumprida. O Jango sempre comentava, depois o Cristino, mas nunca ninguém tinha conseguido ir. Eu também não tinha previsão de ir, por que agente fica meio acanhado, meio sem jeito de falar com o padre. Mas ai como aconteceu esse imprevisto, nós fomos. Eu anunciei como foi o caso, cantei a oração de São João Batista, que nós temos também. Alguns podem não ter gostado, mas nós cantamos.

Cantei também lá no Acaraú.

Mas é verdade: os padres e mesmo aqui no Porto não dão muito importância para o terço. Mas nós damos muito valor, eu principalmente sinto muito valor.

PERGUNTA: Por que, qual é a importância pra você?

$\mathrm{Eu}$ acho importante por que foi a primeira doutrina que eu cresci nela. O modo que eu acompanhei a igreja católica foi nesse tipo de reza. Como eu cresci nisso e me acostumei, eu sinto muito fé.

\section{PERGUNTA: E como o senhor define a fé?}

Eu defino fé por que eu acredito em Deus e para acreditar em Deus é preciso ter fé. Agente tendo fé em Deus agente tem fé naquilo que agente faz e faz com amor. Então pra eu pedir pra Deus a proteção pra que ele me socorra, me ajude, ajude minha família, meus filhos e todos aqueles que necessitam é preciso ter fé e acreditar. Por que, por exemplo, nós estamos conversando, se eu não tiver amor e fé na nossa conversa não adianta nada, não é verdade? Então eu acredito que a fé seja isso ai. 
Pelo menos nós que nascemos e crescemos lá no sítio, nós não tínhamos médicos, era difícil ir no médico na cidade, então agente acreditava nos curadores. Quando ficava uma pessoa doente agente corria para o curador, os benzedores. Ali eles ensinavam...

\section{PERGUNTA: Quem era o curador?}

Primeiro era João Vicente, o Jango. Mas antes tinha um homem do Aririaia, o Clarindo Gonçalves dos Santos, que era o maior curador que existia aqui na redondeza de Cananéia. Esse era um homem que muitas pessoas, gente de dinheiro, quando ficava doente corria pra casa dele. Mas no Mandira, antes de Jango tinha o Clarindo, depois um homem do Taquari chamado Nascimento, um preto que também entendia muito de cura de reza, ai depois o Jango. Esse entendia muito bem também. Ele sabia curar. A pessoa tinha qualquer coisa, febre ele ensinava remédio ou fazia benzimento conforme ele sabia. Tudo na parte espiritual que ele trabalhava. Eu cheguei a ver muito ele trabalhando. O trabalho dele é o tipo de trabalho que chamam de sessão. A sessão é assim, a pessoa que trabalha na linha espírita faz esse tipo de trabalho. As pessoas se reúnem, arrumam uma mesa, forravam com uma toalha, ai na hora invocava um espírito nele e a falava, falava. Eu não entendo como é, só sei por que eu via como eles faziam, né? E eles acreditavam naquilo ali, né? $\mathrm{O}$ importante é que eles acreditavam, se era certo ou não agente não tem certeza, mas agente acreditava e dava resultado perfeitamente. Ele em vida, quando trabalhava, juntava muita gente. Vinha muita gente de longe, aqui de Pariquera, de toda essa parte, todos rezavam com ele e todos ficavam contentes com o trabalho dele.

PERGUNTA: Sua posição no terço é de Capelão, né?

Sim, quem dirige o terço, o dirigente recebe o nome de capelão.

PERGUNTA: E sempre tem que ser homem?

Não. Poderia ser mulher também. É que nós pra cá nunca teve uma mulher que se prontificasse em assumir. Tradicionalmente foi sempre os homens. Por que nós aqui no sítio, as mulheres sempre acompanharam, mas nunca se prontificaram a dirigir aquilo ali, né? Talvez eles achavam, entre os nossos antepassados, que as mulheres não poderiam passar na frente. Penso eu que pode ser isso. Então eles poderiam ficar meio acanhado, envergonhado se a mulher fosse dirigir o terço e os homens fossem ficar de lado. Eu acho que foi isso o problema deles, também, né? Não que elas não soubessem. Como nós lá, em que minhas tias, as mulheres eram ajudantes de terço, talvez elas rezem melhor do que nós os homens, sabe? Mas só que é para ajudar, né? Não dirigir.

Por que a importância do Capelão é começar as orações. Todas as orações eu começo e os ajudantes prosseguem. Por que no tempo do Cristino agente aprendeu a rezar junto. Então agente começava a oração, ele começava cantar um verso e eu entoava. Ai depois eu continuava e ele prosseguia. Ai ficava que cada um cantava um verso. Eu acho que ficava mais bonito do que agora. Mas depois que ele morreu não teve um camarada que ajudasse pra mim. Então eu tenho que começar e levar do começo ao fim. E a oração do terço é um cântico devagar, meio parado. E as vezes a oração demora bastante pra terminar e cansa bastante agente. Principalmente eu que to chegando a uma idade que tenho dificuldade de começar e levar a oração até o fim, né? Mas a obrigação do capelão é começar a oração.

No tempo do meu tio eles não costumavam ler a bíblia no terço e hoje agente acha que é importante ler a bíblia. Por que a bíblia faz parte de todo o tipo de oração, então tem uma parte do terço que eu leio a bíblia, também. E tudo isso faz parte do Capelão. Falar 
alguma coisa, pedir a proteção, pedir ajuda, sempre o Capelão que conduz tudo isso ai, né? E os ajudantes ajudam a cantar e acompanham.

Eu me sinto muito feliz quando estou rezando o terço. Inclusive eu me acostumei com o terço. Nessa época da quaresma eu fico desgostoso comigo mesmo se eu não rezar um terço durante a quaresma. $\mathrm{Na}$ hora que eu começo a rezar eu fico muito contente, muito feliz.

PERGUNTA: Como capelão o senhor se sente responsável pelo lado espiritual de fé dos Mandira?

Sim, perfeitamente. Eu não me considero como melhor que eles ou qualquer outra pessoa. Não faço por exibição ou para levar o nome. Eu faço por prazer. E pra que eles se sintam felizes e possam dar continuidade quando eu não puder mais rezar ou Deus me tirar desse mundo, mas eles sempre continuem. É por isso mais que eu faço força pra estar com eles rezando. Inclusive agora que eles rezaram sozinho, eu fiquei satisfeito, por que é uma parte que eu estou vendo que quando eu sair desse mundo não vai acabar. Por que se eles começaram eles tem o poder e força de dar continuidade. Na verdade ainda com tudo ainda não saiu bem certo, principalmente no começo do terço, como estávamos conversando. Mas eu sei que sempre vai melhorar, por que eles sabem tudo desde o começo, sabem como é.

\section{PERGUNTA: Mas como é o começo?}

Tem as orações certas do começo. Toda reza tem seu começo. Seja no terço seja em missa tem as orações do começo.

Seja em terço seja em missa sempre tem o início. Por que o começo do terço, desde o tempo de meus avós sempre é o "Deus vos salve". Este é o começo do terço. Mas nós não cantava por que não tínhamos muita experiência em cantar o "Deus vos salve" cantado sempre agente Fazia ele rezado, sabe?

Então sempre agente começava o terço com "Glória ao pai"e "Deua vos salve"sempre é cantado, entende? Então ai é rezado "Deus vos salve", ai é rezado "Glória ao pai", depois o "Pai nosso", "Ave Maria".

PERGUNTA: Mas o terço sempre foi cantado?

Sempre foi cantado.

Ai depois de cantar "Ave Maria", e na terceira parte "nessa mesa me ajoelho pra oração". Pois a oração toda vida foi cantado também, no começo do terço. Ai depois era rezado "Salve rainha", que tá tudo marcado aqui no livro.

Do livro eu gostei muito. Mas eu gostei por que pra mim mesmo eu entendo, eu sei de tudo que está escrito aqui, sabe? Do início do terço eu sei de tudo. Mas pra quem não sabia, que nem eles mesmo lá, que não sabiam, foi bom ser escrito tudo por que eles estão sabendo como começa e como termina.

Então depois de "Nessa mesa me ajoelho", ai nós podemos escolher a oração que queremos catar, sabe? Ai tem "Bendita divina", tem "Estrela do céu", tem "Virgem santíssima"... Então não tem u8ma ordem certa, mas no começo do terço tem uma ordem certa, onde o principal é "Deus vos salve" esse é o principal no começo do terço nosso. Ai depois é "Glória ao pai" cantado e o "Pai nosso"e "Ave Maria".

Posso cantar um trechinho... O "Deus vos salve" começa assim: 
(...) Esse é o começo do terço. Ai depois continua. Agora, eu... nós... assim, como não cantava "Deus vos salve", então sempre começava assim: [canta Glória ao pai]

(...) Esse aqui é o início do culto. Ai vai... Nós temos muita oração. São 43 orações.

PERGUNTA: Todas gravadas na memória do senhor?

Tudo gravada. Não... oh, não... o defeito foi que... algumas orações... O meu tio sabia todas essas orações de cora. Nesse tempo não tinha livro.

PERGUNTA: Seu tio Jango?

É, o Jango e o Cristino. O Cristino já era primo, mas ele sabia também. Ele sabia, mas o Jão mandira, O Cristino sabia todas as orações, tudo isso aqui cantado. Ai antes dele morrer, ele era um homem tão curioso, que ele sabia que eu não sabia as orações de cora, ai ele tirou tudo em papel. Eu tenho as orações escrita por ele. Ele escreveu tudo, tudo, tudo. E ele nunca foi a escola e se o senhor ver a letra dele, a letra dele é uma letra bem caprichada, sabe?

A ladainha que nos temos a Ladainha de Nossa senhora, que tem nos livros de canto da igreja, eles cantavam. Assim, a ladainha começa assim:

(...) Toda essa parte aqui, eles sabiam tudo de cora.

PERGUNTA: Impressionante, né? E essa toada do terço é algo hipnótico. Parece que vai colocando agente em uma vibração mais elevada.

Justamente, por causa disso eu acho que as pessoas de hoje que não estão acostumado com as orações do terço eles não dão atenção, né? Por que a constante do culto da igreja... do terço não é um cântico assim devagar... modo cansado, que vai assim...

PERGUNTA: Mas não tem assim um terço uma oração de cura, pra curar as pessoas.

Não isso não tem. Mas agente como de costume, e o padre também, como o padre faz a missa, ai tem uma hora que eles fazem aqueles pedidos, imploram proteção, saúde e tal. E no terço agente faz também. Então agente reza o terço e naquela hora depois do evangélico, agente costuma rezar um "Pai nosso, uma "Ave Maria", pede a proteção, saúde, cura, então agente faz aqueles pedidos.

PERGUNTA: Mas o senhor disse que as vezes vai rezar o terço na casa das pessoas? Mas é em datas especiais?

Não, agente reza em qualquer data. Por que principalmente lá no sítio, que não tinha missa, não tinha padre, então um dia agente pedia pro Capelão rezar na casa das pessoas. Em qualquer dia, não tinha data certa. Principalmente em dia santo, por que dia Santo sempre é um dia santificado. Quando era um dia santo agente não ia trabalhar, agente ficava guardando, ficava em casa, ia visitar um parente, um conhecido. Então naquele dia agente sempre costumava chamar o Capelão pra rezar em casa.

$\mathrm{E}$ afinal estamos dando continuidade. O terço é isso ai.

Agora sexta-feira da paixão, agente costuma rezar meio dia, então eles vão vir me buscar pra rezar o terço agora sexta-feira próxima.

O meu avô tinha uma questão com o Cabral, por que o Cabral queria tomar o terreno, né? E meu avô questionava pra ficar com as terras, ora que nós continuássemos vivendo lá, né? Eles questionou durante muito tempo. Ele ia pra Cananéia, ia pra Iguape, ia pra Santos.

PERGUNTA: Cabral era um fazendeiro? 
Era um fazendeiro, que morava em São Paulo, eu acho. Só que o Cabral era muito rico, dono de muitas terras. No município de Cananéia no continente tudo era deles. Eles tomavam conta desde aqui de Itapitanguí até umas partes das bandas do sul pra lá eles tinham como tudo deles. Então meu avô brigava por causa dessas terras do Mandira, que eles queriam tomar. Mas só que meu avô era muito respeitado, sabe? Meu avô era muito conhecido e ele sabia muito lutar pela questão de terra. Só que em Cananéia eles sabiam dos direitos que meu avô tinha, mas eles não davam aquele direito dele. E ele não tinha dinheiro pra pagar advogado pra ajuda-lo. Então ele tinha que trabalhar com as forças e poder dele. Quando ele não tinha dinheiro pra pagar as viagens pra Santos, ele mandava os filhos trabalhar, fazer canoas, cortar madeiras pra vender e ele arrecadar o dinheiro pra pagar as viagens dele.

PERGUNTA: D. Saturnina contou que João Mandira brigava muito com seu irmão Antônio, eles eram irmão ou primo?

Eles eram irmãos.

PERGUNTA: E como eram as brigas entre eles?

Eles brigavam por que o terreno... os Mandira não é dos Mandira... quinem tem o salto em cima e os Mandira cá em baixo. Então a divisa do salto e dos Mandira cá em baixo eles fizeram entre eles por causa da questão deles também, dos dois irmãos. Então eles questionavam por causa do João não passar pra lá e o Antônio não passar pra cá pra baixo. Isso no tempo do Cabral, mas a briga entre os dois irmãos não tem nada a ver com a questão do Cabral. Por que o Cabral queria tomar pra atirar os Mandira de lá e os dois irmãos brigavam só por causa de um não invadir o lugar do outro. Então ficava a complicação entre eles: João respeitava o Antônio lá pra cima e o Antônio respeitava o João pra baixo.

Meu avô brigou muito com esse pessoal [dos Cabral] por causa das terras do Mandira. Inclusive João Mandira ganhou a questão com os Cabral, por que eles nunca puderam tirar o João Mandira de lá. Mas eles também não davam os direitos dele, por que o Cabral era pessoa de muito recurso, muito dinheiro e sempre tinha mais força. As autoridades de Cananéia tinham muito respeito por João, mas não davam os seus direitos. 